In cooperation with the City of Independence, Missouri, Water Department

\title{
Contributing Recharge Areas, Groundwater Travel Time, and Groundwater Quality of the Missouri River Alluvial Aquifer near the Independence, Missouri, Well Field, 1997-2008
}

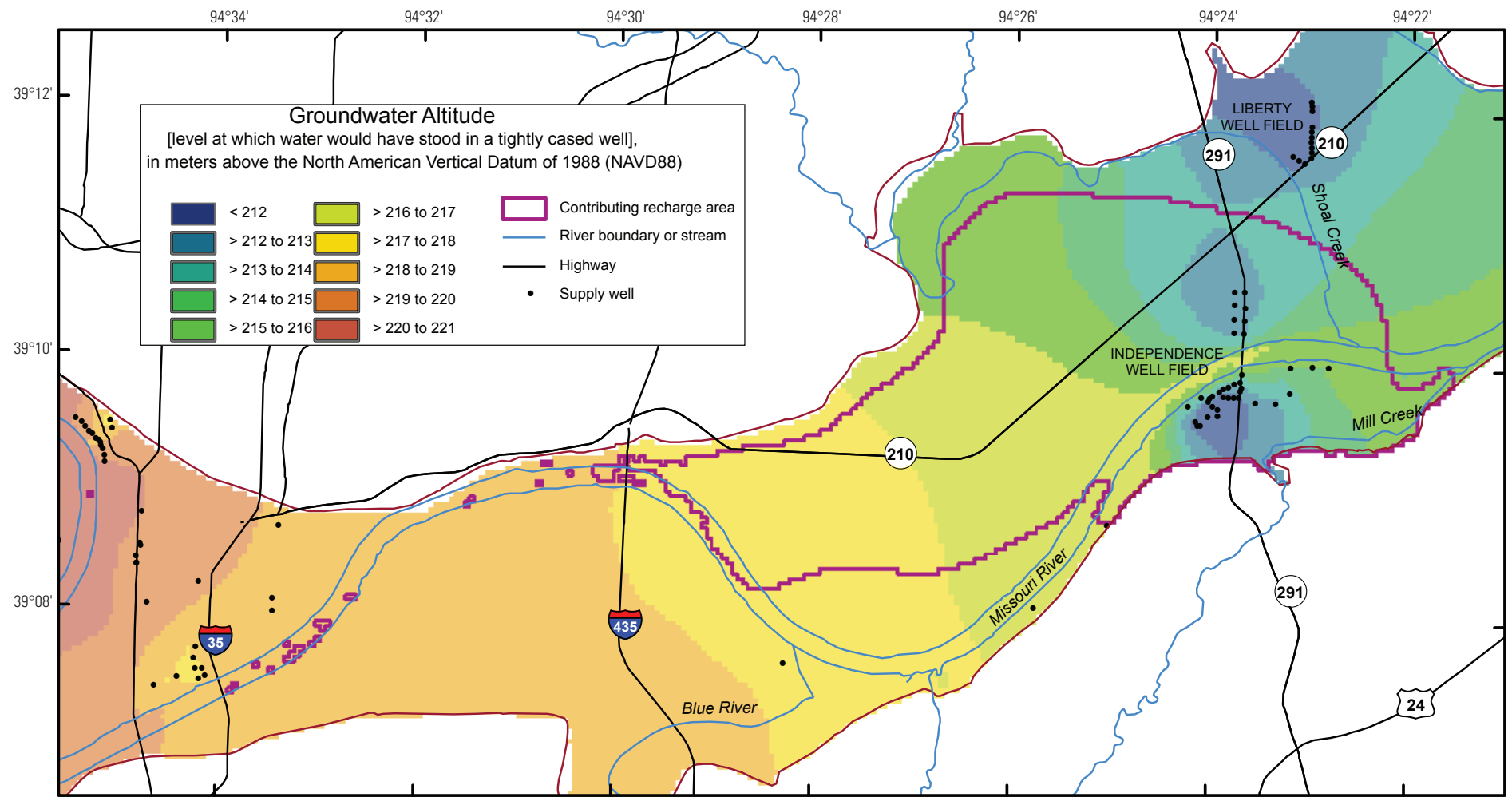

Scientific Investigations Report 2010-5232 
Cover: Map showing simulated groundwater altitude and contributing recharge area to supply wells in the Independence well field. Base from U.S. Geological Survey, digital data 1:100,000, 2005, Universal Transverse Mercator projection, Zone 15 


\section{Contributing Recharge Areas, Groundwater Travel Time, and Groundwater Quality of the Missouri River Alluvial Aquifer near the Independence, Missouri, Well Field, 1997-2008}

By Brian P. Kelly

In cooperation with the City of Independence, Missouri, Water Department

Scientific Investigations Report 2010-5232 


\title{
U.S. Department of the Interior \\ KEN SALAZAR, Secretary \\ U.S. Geological Survey \\ Marcia K. McNutt, Director
}

\section{U.S. Geological Survey, Reston, Virginia: 2011}

\author{
For more information on the USGS — the Federal source for science about the Earth, its natural and living resources, \\ natural hazards, and the environment, visit http://www.usgs.gov or call 1-888-ASK-USGS \\ For an overview of USGS information products, including maps, imagery, and publications, \\ visit http://www.usgs.gov/pubprod \\ To order this and other USGS information products, visit http://store.usgs.gov
}

\begin{abstract}
Any use of trade, product, or firm names is for descriptive purposes only and does not imply endorsement by the U.S. Government.

Although this report is in the public domain, permission must be secured from the individual copyright owners to reproduce any copyrighted materials contained within this report.
\end{abstract}

Suggested citation:

Kelly, B.P., 2011, Contributing recharge areas, groundwater travel time, and groundwater water quality of the Missouri River alluvial aquifer near the City of Independence, Missouri, well field, 1997-2008: U.S. Geological Survey Scientific Investigations Report 2010-5232, 133 p. 


\section{Contents}

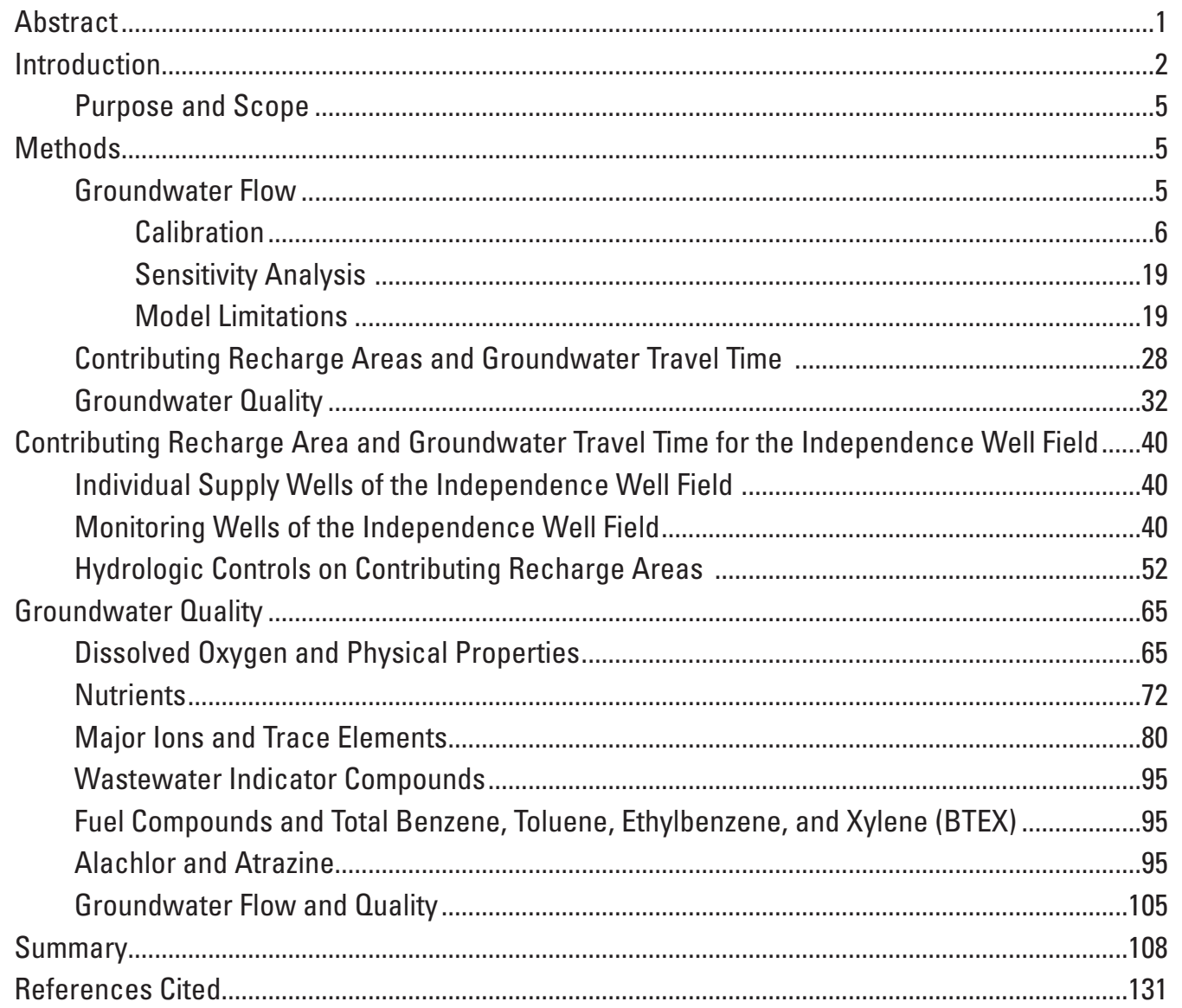




\section{Figures}

1-5. Maps showing

1. Location of model area. .3

2. Locations and well identifiers of supply wells and monitoring well nests in the Independence well field.

3. Location of new and existing depth to bedrock data in the model area.....................6

4. Assumed hydraulic head distribution for August 1993 initial conditions of the original simulation and simulated hydraulic head distribution of August 1993 for the updated transient simulation .

5. Locations where water-levels were measured ........................................................10

6-9. Graphs showing

6. Daily Missouri River altitude at the U.S.Geological Survey streamgage at Kansas City, Missouri (site number 06893000) from October 1, 1990 to December 31, 1999 (observation at 8:00 AM).

7. Daily rainfall used for groundwater simulations from October 1, 1990 to December 31, 1999

8. Daily water-level observations and simulated equivalents for wells located near Atherton, Missouri

9. Quarterly and annual water-level observations and simulated equivalents for Independence monitoring wells with 3 or more measurements

10-14. Maps showing

10. Horizontal hydraulic conductivity for each model layer ..........................................21

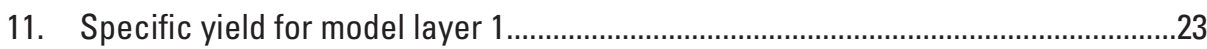

12. Areal distribution of recharge as a percentage of rainfall.....................................23

13. Change in simulated water levels for the 2007 base simulation resulting from doubling well pumpage, the parameters HK34_6, HK34_7, HK2_6, HK34_5, HK2_4, RPARM, and recharge...

14. Estimated porosity distribution by model layer ....................................................30

15. Diagram showing features of boxplots used in this report ..............................................36

16. Graph showing elected quality assurance data for sample and replicate sample pairs

17-23. Maps showing

17. Simulated groundwater altitude and contributing recharge area for the Independence well field

18. Simulated groundwater travel time within the contributing recharge area for the Independence well field

19. Contributing recharge areas calculated using endpoint analysis and groundwater flow paths calculated using flow-path analysis for each supply well of the Independence well field

20. Groundwater flow paths from the Missouri River or land surface to monitoring wells and from monitoring wells to supply wells of the Independence well field

21. Contributing recharge areas and groundwater flow paths from contributing recharge areas to monitoring wells grouped by model layer for the Independence well field

22. Groundwater flow paths from monitoring wells grouped by model layer to supply wells of the Independence well field. 
23. Locations of potential sources and source areas of groundwater contamination near the Independence well field. .66

24. Boxplots of dissolved oxygen, $\mathrm{pH}$, specific conductance, and temperature for water samples from each monitoring well and hte combined well-field sample.

25. Graphs showing dissolved oxygen, $\mathrm{pH}$, specific conductance, and temperature and linear trend of median values for water samples from monitoring wells grouped by depth interval

26. Maps showing the areal distribution of median values of $\mathrm{pH}$ for water samples from monitoring wells grouped by depth interval

27. Maps showing the areal distribution of median values of specific conductance for water samples from monitoring wells grouped by depth interval.

28. Boxplots and linear trend of median $\mathrm{pH}$ and median specific conductance for water samples from monitoring wells grouped by year

29. Boxplots of selected nutrients for water samples from all monitoring wells

30. Boxplots of total inorganic nitrogen (ammonia plus nitrate plus nitrite) and orthophosphate for water samples from each monitoring well

31. Graphs showing total inorganic nitrogen (ammonia plus nitrate plus nitrite) and orthophosphate and linear trend of median concentrations for water samples from monitoring wells grouped by depth

32. Maps showing the areal distribution of median concentrations of total inorganic nitrogen (ammonia plus nitrate plus nitrite) for water samples from monitoring wells grouped by depth interval.

33. Maps showing the areal distribution of median concentrations of orthophosphate for water samples from monitoring wells grouped by depth interval.

34. Boxplots and linear trend from 1998 to 2008 of median concentrations of total inorganic nitrogen (ammonia plus nitrate plus nitrite) and orthophosphate for water samples from monitoring wells grouped by year

35. Boxplots of dissolved major ions and iron for water samples from all monitoring wells

36. Boxplots of dissolved major ions and iron for water samples from each monitoring well.

37. Boxplots of dissolved trace elements for water samples from all monitoring wells ......89

38. Boxplots of dissolved antimony, arsenic, barium, manganese for water samples from each monitoring well

39. Graphs showing major ions and iron concentrations and linear trend of median concentrations for water samples from monitoring wells grouped by depth interval.

40. Graphs showing antimony, arsenic, barium, and manganese concentrations and linear trend of median concentrations for water samples from monitoring wells grouped by depth interval

41. Maps showing median concentrations of selected major ions and trace elements for water samples from monitoring wells grouped by well nest

42. Boxplots of dissolved major ions iron and linear trend of median concentrations for water samples from all monitoring wells grouped by year

43. Map showing wastewater indicator compound detections in water samples from monitoring wells grouped by well nest

44. Graph showing percentage of wells sampled with one or more detections of wastewater indicatorcompounds for water samples from monitoring wells grouped by year 
45. Maps showing detections of fuel compounds and total BTEX (benzene, ethylbenzene, toluene, and xylene) in water samples for monitoring wells grouped by well nest.

46. Graph showing number of samples with detections and non-detections of fuel compounds and total BTEX (benzene, toluene, ethylbenzene, and xylene) for water samples from monitoring wells grouped by year.

47. Boxplots for alachlor and atrazine for water samples from all monitoring wells..........105

48. Maps showing percentage of detections for alachlor and atrazine in water samples from monitoring wells grouped by well nest...

49. Graphs sowing percentage of detections for alachlor, and atrazine in water samples from monitoring wells grouped by year.

\section{Tables}

1. Original and updated simulation characteristics ..........................................................

2. Updated quasi-steady-state initial conditions groundwater flow budget .........................9

3. Water-level altitudes in monitoring wells near the Independence well field (1993-1999) .110

4. U.S. Geological Survey site numbers for wells near Atherton, Missouri.

5. Well pumpage used for the transient calibration simulation

6. Parameter names, types, layer and zone number, updated value, original range of values, porosity, and original porosity range.

7. 2007 average annual well pumpage for Independence and other supply wells used for the steady-state 2007 base simulation

8. Steady-state 2007 base simulation groundwater flow budget

9. Selected water-quality constituents analyzed in samples collected from the Independence monitoring wells.

10. Total number of samples for each monitoring well and number of analyses for each water-quality constituent group......

11. Concentrations of selected constituents in blanks, replicates, and samples.

12. Percentage of particles from the Missouri River and land surface, groundwater travel times, and size of the contributing recharge area for each supply well calculated using endpoint analysis

13. Percentage of particles from the Missouri River and land surface and groundwater travel times for each supply well calculated using flow-path analysis

14. Monitoring well identifier, previous monitoring well identifier, land surface altitude, and well depth.

15. Monitoring well, percentage of particles from the Missouri River and land surface, and groundwater travel times from monitoring well contributing recharge areas to each monitoring well.

16. Monitoring well, percentage of particles to each supply well, and groundwater travel times from monitoring wells to each supply well.

17. Geographic information system data sources for potential groundwater contamination near the Independence well field

18. Information for potential sources of potential groundwater contamination near the Independence well field.

19. Detections of wastewater indicator compounds in water samples from monitoring wells. 
20. Detections of fuel compounds and total BTEX (benzene, toluene, ethylbenzene, and xylene) in water samples from monitoring wells.

21. Results of enzyme-linked immunosorbent assay (ELISA) analyses of total BTEX (benzene, toluene, ethylbenzene, and xylene), alachlor, and atrazine for water samples from all monitoring wells

\section{Conversion Factors}

\section{SI to Inch/Pound}

\begin{tabular}{|c|c|c|}
\hline Multiply & By & To obtain \\
\hline \multicolumn{3}{|c|}{ Length } \\
\hline meter $(\mathrm{m})$ & 3.281 & foot $(\mathrm{ft})$ \\
\hline kilometer (km) & 0.6214 & mile (mi) \\
\hline \multicolumn{3}{|c|}{ Area } \\
\hline square meter $\left(\mathrm{m}^{2}\right)$ & 0.0002471 & acre \\
\hline square kilometer $\left(\mathrm{km}^{2}\right)$ & 247.1 & acre \\
\hline square centimeter $\left(\mathrm{cm}^{2}\right)$ & 0.001076 & square foot $\left(\mathrm{ft}^{2}\right)$ \\
\hline square meter $\left(\mathrm{m}^{2}\right)$ & 10.76 & square foot $\left(\mathrm{ft}^{2}\right)$ \\
\hline \multicolumn{3}{|c|}{ Volume } \\
\hline liter $(\mathrm{L})$ & 33.82 & ounce, fluid (fl. oz) \\
\hline cubic meter $\left(\mathrm{m}^{3}\right)$ & 264.2 & gallon (gal) \\
\hline cubic meter $\left(\mathrm{m}^{3}\right)$ & 0.0008107 & acre-foot (acre-ft) \\
\hline \multicolumn{3}{|c|}{ Flow rate } \\
\hline meter per day $(\mathrm{m} / \mathrm{d})$ & 3.281 & foot per day (ft/d) \\
\hline cubic meter per day $\left(\mathrm{m}^{3} / \mathrm{d}\right)$ & 35.31 & cubic foot per day $\left(\mathrm{ft}^{3} / \mathrm{d}\right)$ \\
\hline cubic meter per day $\left(\mathrm{m}^{3} / \mathrm{d}\right)$ & 264.2 & gallon per day (gal/d) \\
\hline cubic meter per second $\left(\mathrm{m}^{3} / \mathrm{s}\right)$ & 35.31 & cubic foot per second $\left(\mathrm{ft}^{3} / \mathrm{s}\right)$ \\
\hline \multicolumn{3}{|c|}{ Hydraulic conductivity } \\
\hline meter per day $(\mathrm{m} / \mathrm{d})$ & 3.281 & foot per day (ft/d) \\
\hline
\end{tabular}

Temperature in degrees Celsius $\left({ }^{\circ} \mathrm{C}\right)$ may be converted to degrees Fahrenheit $\left({ }^{\circ} \mathrm{F}\right)$ as follows:

$$
{ }^{\circ} \mathrm{F}=\left(1.8 \times{ }^{\circ} \mathrm{C}\right)+32
$$

Temperature in degrees Fahrenheit $\left({ }^{\circ} \mathrm{F}\right)$ may be converted to degrees Celsius $\left({ }^{\circ} \mathrm{C}\right)$ as follows:

$$
{ }^{\circ} \mathrm{C}=\left({ }^{\circ} \mathrm{F}-32\right) / 1.8
$$

Vertical coordinate information is referenced to the North American Vertical Datum of 1988 (NAVD 88)

Horizontal coordinate information is referenced to the North American Datum of 1983 (NAD 83) Altitude, as used in this report, refers to distance above the vertical datum.

Specific conductance is given in microsiemens per centimeter at 25 degrees Celsius $(\mu \mathrm{S} / \mathrm{cm}$ at $\left.25^{\circ} \mathrm{C}\right)$.

Concentrations of chemical constituents in water are given either in milligrams per liter (mg/L) or micrograms per liter $(\mu \mathrm{g} / \mathrm{L})$. 



\title{
Contributing Recharge Areas, Groundwater Travel Time, and Groundwater Quality of the Missouri River Alluvial Aquifer near the Independence, Missouri, Well Field, 1997-2008
}

\author{
By Brian P. Kelly
}

\section{Abstract}

The City of Independence, Missouri, operates a well field in the Missouri River alluvial aquifer. Contributing recharge areas (CRA) were last determined for the well field in 1996. Since that time, eight supply wells have been installed in the area north of the Missouri River and well pumpage has changed for the older supply wells. The change in pumping has altered groundwater flow and substantially changed the character of the CRA and groundwater travel times to the supply wells.

The U.S Geological Survey, in a cooperative study with the City of Independence, Missouri, simulated steady-state groundwater flow for 2007 well pumpage, average annual river stage, and average annual recharge. Particle-tracking analysis was used to determine the CRA for supply wells and monitoring wells, and the travel time from recharge areas to supply wells, recharge areas to monitoring wells, and monitoring wells to supply wells. The simulated CRA for the well field is elongated in the upstream direction and extends to both sides of the Missouri River. Groundwater flow paths and recharge areas estimated for monitoring wells indicate the origin of water to each monitoring well, the travel time of that water from the recharge area, the flow path from the vicinity of each monitoring well to a supply well, and the travel time from the monitoring well to the supply well.

Monitoring wells 14a and 14b have the shortest groundwater travel time from their contributing recharge area of 0.30 years and monitoring well 29a has the longest maximum groundwater travel time from its contributing recharge area of 1,701 years. Monitoring well 22a has the shortest groundwater travel time of 0.5 day to supply well 44 and monitoring well $3 \mathrm{~b}$ has the longest maximum travel time of 31.91 years to supply well 10 .

Water-quality samples from the Independence groundwater monitoring well network were collected from 1997 to 2008 by USGS personnel during ongoing annual sampling within the 10-year contributing recharge area (CRA) of the Independence well field. Statistical summaries and the spatial and temporal variability of water quality in the Missouri River alluvial aquifer near the Independence well field were characterized from analyses of 598 water samples. Waterquality constituent groups include dissolved oxygen and physical properties, nutrients, major ions and trace elements, wastewater indicator compounds, fuel compounds, and total benzene, toluene, ethylbenzene, and xylene (BTEX), alachlor, and atrazine. The Missouri Secondary Maximum Contaminant Level (SMCL) for iron was exceeded in almost all monitoring wells. The Missouri Maximum Contaminant Level (MCL) for arsenic was exceeded 32 times in samples from monitoring wells. The MCL for barium was exceeded five times in samples from one monitoring well. The SMCL for manganese was exceeded 160 times in samples from all monitoring wells and the combined well-field sample. The most frequently detected wastewater indicator compounds were $N, N$-diethyl$m e t a$-toluamide (DEET), phenol, caffeine, and metolachlor. The most frequently detected fuel compounds were toluene and benzene. Alachlor was detected in 22 samples and atrazine was detected in 37 samples and the combined well-field sample. The MCL for atrazine was exceeded in one sample from one monitoring well.

Samples from monitoring wells with median concentrations of total inorganic nitrogen larger than 1 milligram per liter $(\mathrm{mg} / \mathrm{L})$ are located near agricultural land and may indicate that agricultural land practices are the source of nitrogen to groundwater. Largest median values of specific conductance; total inorganic nitrogen; dissolved calcium, magnesium, sodium, iron, arsenic, manganese, bicarbonate, and sulfate and detections of wastewater indicator compounds generally were in water samples from monitoring wells with CRAs that intersect the south bank of the Missouri River. Zones of higher specific conductance were located just upstream from the Independence well field at south-bank outfalls from wastewater treatment plants, the Blue River, and the south bank of 
the Missouri River near the closed oil refinery. The long-term presence of these south-bank outfalls and the large specific conductance indicate that the surface water at the south bank of the Missouri River near the Independence well field may have consistently higher dissolved solids and nutrients that can be induced into the aquifer by pumping. Large median concentrations of sodium and chloride from samples from monitoring wells may be the result of road salt use on State Highway 291 or from Mill Creek, which drains the uplands south of the Independence well field. Large median concentrations of arsenic in samples from some monitoring well nests are most likely associated with dissolution of iron and sulfide minerals and fluctuation between oxidizing and reducing conditions. Largest median concentrations for arsenic are in the shallow depth interval where fluctuations between oxidizing and reducing conditions occur. Median concentrations of iron are large in all monitoring wells and are most likely caused by the interaction between fluctuating oxidizing and reducing conditions and siderite and ferric hydroxide.

Spatial and temporal trends are not evident from the fuel compounds or total BTEX sample results. Alachlor and atrazine were detected in most monitoring wells and atrazine was detected more often than alachlor. The source of alachlor and atrazine in groundwater near the Independence well field is most likely from nearby agricultural land management practices and (or) the Missouri River. Many of the samples from monitoring wells with alachlor or atrazine detections greater than 10 percent have contributing recharge areas that intersect either agricultural land or the Missouri River bed.

\section{Introduction}

The City of Independence, Missouri, operates a well field within the city limits of Sugar Creek, Missouri, in the Missouri River alluvial aquifer (fig. 1). Current (2010) development and activity near the well field includes three landfills, commercial development, highway construction, highway and rail line traffic, the use of fly ash for mine stabilization south of the well field, a closed oil refinery, land application of solid waste across the river to the west, a demolition landfill north of the well field, and agricultural land use. Non-point source areas related to agricultural use of fertilizers and pesticides are the most widespread sources of potential groundwater contamination to the Independence well field (Kelly, 1996b). However, numerous potential point sources, such as above- and belowground storage tanks, chemical spills along highways or rail lines, or spills in the Missouri River or Mill Creek also are near the well field. The long-term presence of these potential contaminant sources has created concerns about the increased potential for contamination and the cumulative effect of contamination on the quality of the source water to the Independence well field.

In response to concerns regarding potential groundwater contamination, the U.S. Geological Survey (USGS) and the
City of Independence, Missouri, completed studies of groundwater flow in the area of the well field (Kelly and Blevins, 1995; Kelly, 1996a, 1996b). These studies delineated contributing recharge areas (CRAs) to the well field, estimated groundwater travel times, and identified types and locations of potential groundwater contamination source areas. The studies also were used to design a groundwater monitoring network in the area of the Independence well field. Additional studies of the Independence well field by the USGS and the City of Independence included plans for and sampling of the groundwater monitoring well network and estimation of the contribution of the Missouri River to the well field, and the effect of riverbank filtration on the quality of water between the Missouri River and supply wells (Kelly, 1996b, 2002a, 2002b, 2006).

The CRAs were last determined for the Independence well field in 1996 when there were 33 supply wells south of the Missouri River and 6 supply wells planned for the area north of the Missouri River. The proposed locations and pumpage for the supply wells north of the river were part of a planned well-field expansion. Since that time, eight supply wells have been installed in the area north of the Missouri River, well pumpage has changed for the older supply wells, and 40 supply wells were pumped in 2007 . The change in pumping likely has altered groundwater flow and substantially changed the character of the CRA and groundwater travel time north of the Missouri River. Changes in well pumpage south of the Missouri River also likely have altered the character of the CRA and groundwater travel time.

The groundwater monitoring well network, shown in figures 1 and 2, is composed of 68 wells in 29 well nests. Groundwater quality within the estimated 10 -year zone of contribution to the Independence well field (Kelly, 2002a) was monitored in 1997 and 1998, with synoptic sampling of 64 wells in the monitoring well network. Water samples from the monitoring wells in the network were analyzed for constituents likely to originate from potential contamination source areas (Kelly, 2002a). Based on these data, a long-term sampling schedule was developed for the monitoring well network. A short-term sampling schedule also was developed to characterize seasonal changes in selected agricultural chemicals from 1997 to 2000. The short-term sampling schedule included quarterly sampling and analysis for selected constituents of at least one well in each well nest combined with more frequent sampling of a subset of these wells for agricultural chemicals. Analyses of selected water-quality constituents collected for previous studies were used to address the specific objectives of individual investigations (Kelly, 1996b, 2002a, 2002b, 2006). Results presented here include 314 samples collected during long-term groundwater monitoring that had not been used to determine trends or provide an overall waterquality assessment. 

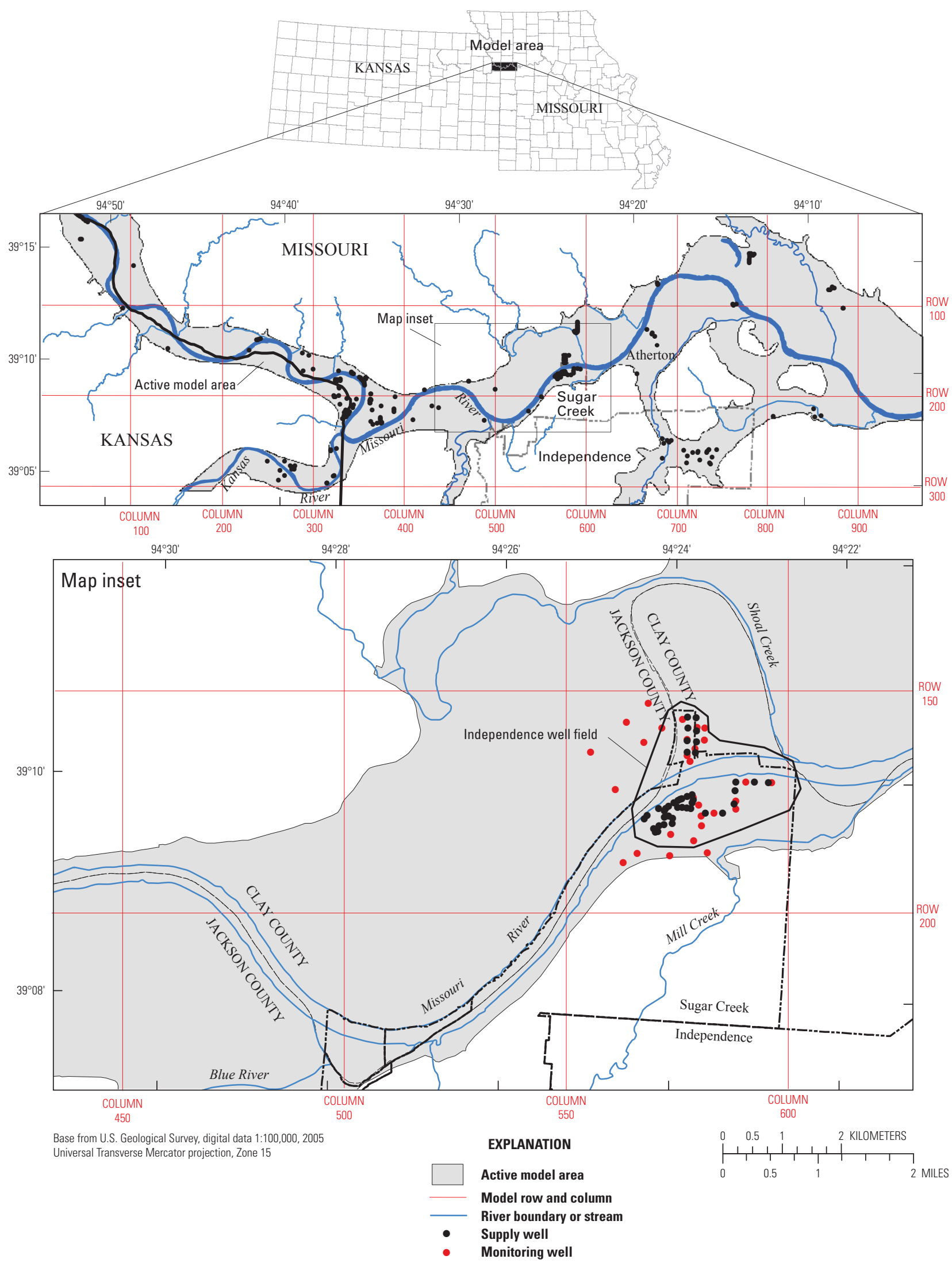

Figure 1. Location of model area. 


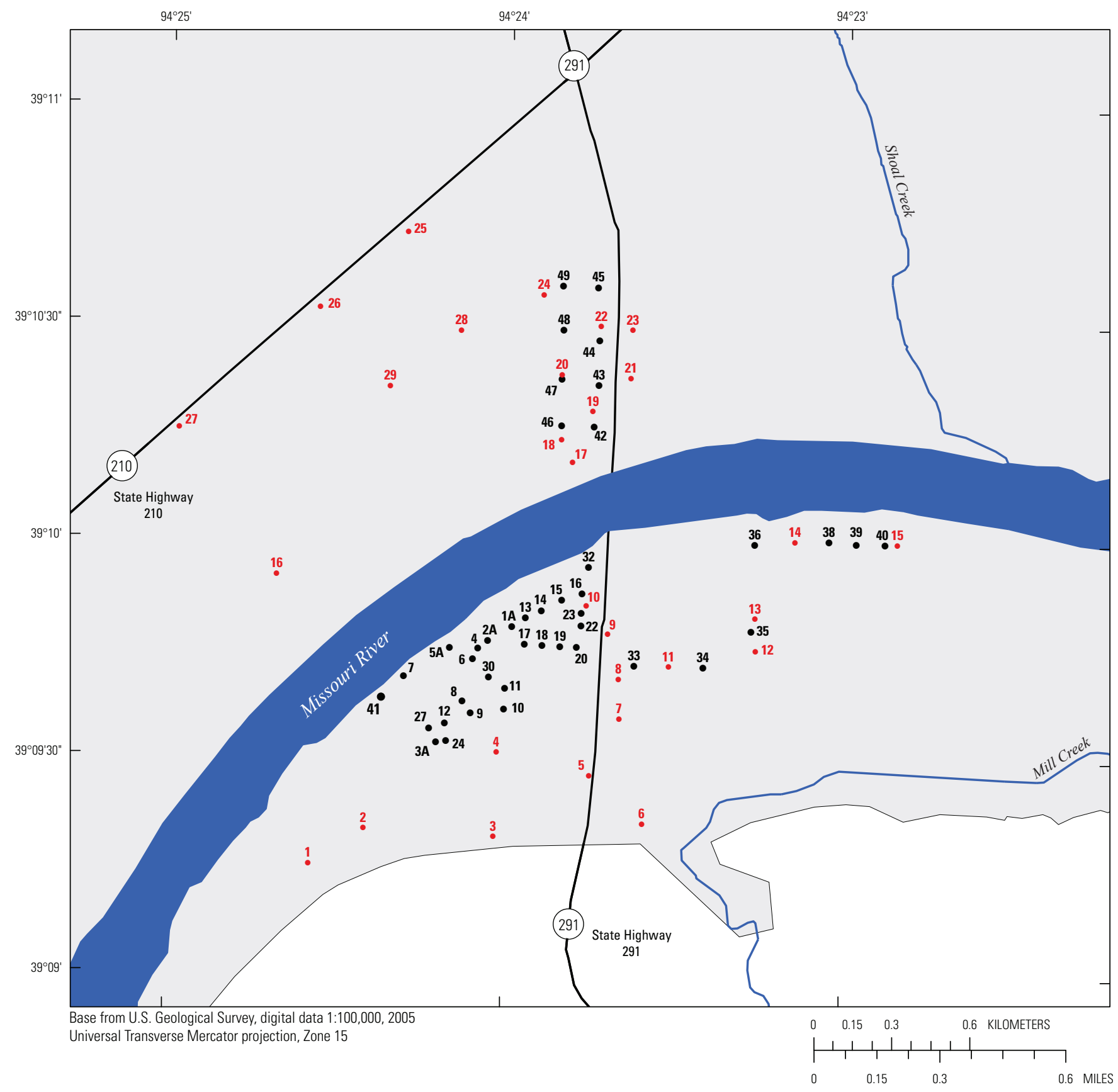

EXPLANATION

Active model area

__ River boundary or stream

- Highway

2- Supply well and identifier

1 - Monitoring well nest and identifier

Figure 2. Locations and well identifiers of supply wells and monitoring well nests in the Independence well field. 


\section{Purpose and Scope}

The purpose of this report is to describe the CRA of the Independence well field, groundwater travel time, the temporal and spatial variability of water quality from 1997 to 2008 in the Missouri River alluvial aquifer within the 10-year zone of contribution of the well field, and the relation between CRAs, groundwater flow, and water quality. This report includes maps of the CRA, groundwater flow paths, groundwater travel time within the CRA, and groundwater travel times between supply wells, monitoring wells, and recharge areas. Temporal and spatial variability and trends of water-quality constituents are based on 598 water-quality samples obtained from 68 wells in the groundwater monitoring network between 1997 and 2008 and are presented in tables and graphs.

\section{Methods}

\section{Groundwater Flow}

Groundwater flow was simulated using the three-dimensional finite-difference groundwater flow modeling program MODFLOW-2005 (Harbaugh, 2005). The simulation presented in this report is based on the model developed by Kelly (1996a). The original simulation from Kelly (1996a) was used to determine steady-state groundwater flow and the CRAs to public water-supply well fields in the model area (fig. 1) for various well pumpage and river stages and was calibrated to quasi-steady-state and transient conditions using an earlier version of the program MODFLOW (McDonald and Harbaugh, 1988). The conceptual flow model and basic hydrologic assumptions used in the original simulation are the basis of the updated simulation in this report. A complete description of the hydrologic system and the original simulation is presented by Kelly (1996a). The updated simulation was calibrated to transient conditions using quasi-steady state initial conditions of average annual river stage, average annual rainfall, and 1990 average annual well pumping, closely replicated the original quasi-steady state and transient calibration, and was used to simulate CRAs based on steady-state conditions for 2007 pumpage from the Independence well field. Original and updated simulation characteristics are listed in table 1.

The updated simulation has uniform cells 75 meters per side in 320 rows, 970 columns, and 4 layers. The irregular shape of the model area decreased the number of active cells in the model to 323,322 , with 89,963 active cells in layer 1; 93,224 active cells in layer 2; 81,077 active cells in layer 3; and 59,058 active cells in layer 4. Within the Missouri River alluvial aquifer in the model area, clay and silt overlie sand and gravel. Layer 1 corresponds to the upper part of the aquifer where clay, silt, and fine-grained sand are dominant. Layers 2 and 3 correspond to the middle part of the aquifer where sand and gravelly sand is dominant. Layer 4 corresponds to deep parts of the aquifer where gravel and sandy gravel are present. The thickness of each layer is variable. All four layers are present in the model area near the Independence well field. Unconfined groundwater flow was simulated in layer 1, and confined groundwater flow was simulated in layers 2, 3, and 4. The vertical conductance (Kelly, 1996a) limits water flow between layers of the model to simulate the vertical anisotropy of hydraulic conductivity within the alluvial aquifer. This anisotropy is greatest in the heterogeneously distributed clay, silty clay, and silt present at shallow depths and represented in the model by layer 1 .

Table 1. Original and updated simulation characteristics.

$[-$, not applicable $]$

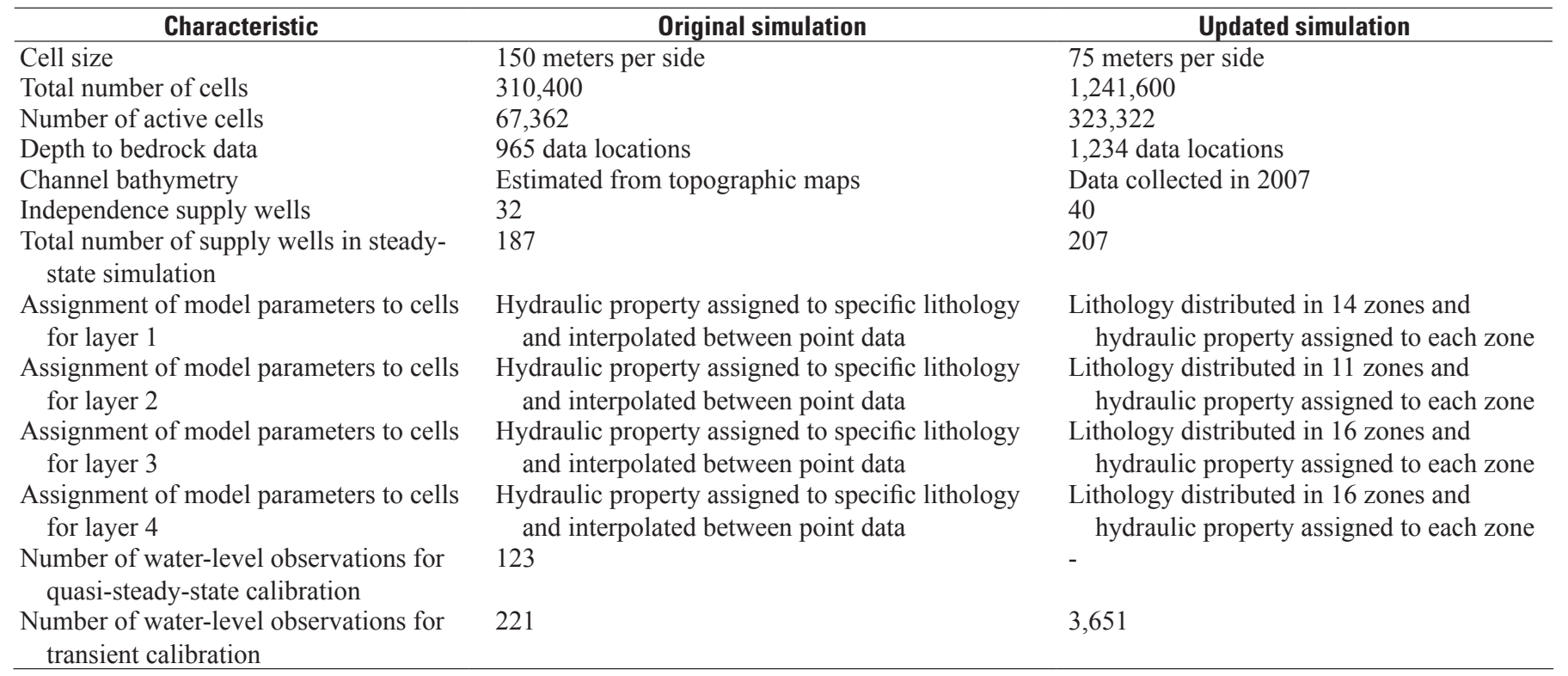


The streambeds of the Missouri and Kansas Rivers were simulated in layer 1 where the river channels are shallow and in layer 2 where the streambeds intersect the sand and gravel that correspond to layer 2. The Missouri River channel bathymetry data collected by the U.S. Army Corps of Engineers (USACE) (USACE, written commun., 2007) was used to define the bottom of the Missouri River in the updated simulation. The streambeds of small rivers were placed in layer 1. Small streams and drainage ditches were simulated as drains (Kelly, 1996a) that receive water from the aquifer, but do not supply water to the aquifer.

The bedrock was simulated as a no-flow boundary because its hydraulic conductivity is several orders of magnitude less than the hydraulic conductivity of the alluvial aquifer (Kelly, 1996a). Additional depth to bedrock data (Missouri Department of Natural Resources, 2006; E.D. Christensen, U.S. Geological Survey, written commun., 2008) were used to refine model geometry in parts of the model area. Locations of new and existing depth to bedrock data are shown in figure 3.

Steady-state groundwater flow, also referred to as the 2007 base simulation in this report, was simulated using average annual groundwater flow conditions determined from average annual river stage data and an average annual rate of recharge from precipitation (Kelly, 1996a). Average annual recharge was calculated as a percentage of the annual precipitation of 0.91 meter $(\mathrm{m})$ and varied spatially depending on the vertical permeability of the soils (Kelly, 1996a). Steady-state well pumpage for all active wells in the 2007 base simulation were set at average annual rates for 2007 (Missouri Department of Natural Resources, 2007b). Locations of Independence well field supply wells used in the simulations are shown in figure 2. The USGS particle-tracking program MODPATH (Pollock, 1994) was used to determine steady-state travel times and CRAs of the Independence well field for the 2007 base simulation. MODPATH uses hydraulic head and cell flow data from MODFLOW to calculate flow paths and travel times of imaginary particles of water moving through the simulated groundwater flow system. Knowledge of the limitations of particle-tracking analysis is necessary to correctly interpret MODPATH results and is given in detail in Pollock (1994). Particle-tracking limitations specific to this simulation are discussed in Kelly (1996a).

\section{Calibration}

The model area of the updated simulation is the same as the original simulation (fig. 1). However, additional water-level information, a finer model discretization, new bathymetry data for the Missouri River, and additional depth to bedrock information incorporated into the model required recalibration. The initial values and distribution of hydraulic properties for simulation recalibration are from Kelly (1996a).

The groundwater flow model was calibrated by adjusting model input data and model geometry until model results matched field observations within an acceptable level of accuracy (Konikow, 1978). Initial recalibration used UCODE_2005, a program that performs sensitivity analysis and parameter estimation using nonlinear regression (Poeter and others, 2005). Simulation of constantly changing river stage, rainfall, and well pumpage using constant values in a succession of one-day stress periods, water-level observations separated by long time,

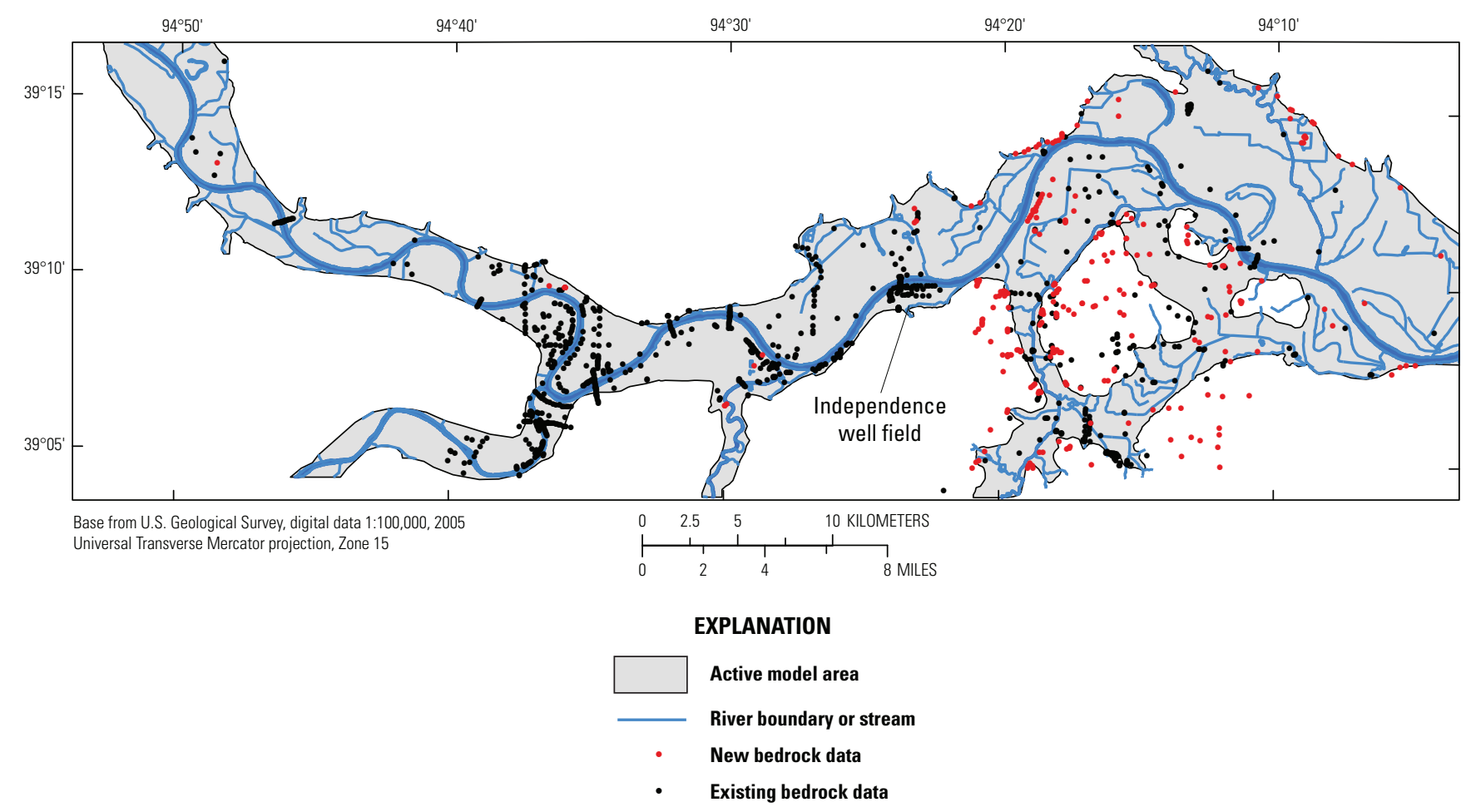

Figure 3. Location of new and existing depth to bedrock data in the model area. 
and the large size and complexity of the simulation resulted in non-convergence for parameter estimation simulations. Consequently, initial estimates of parameter values calculated using UCODE_2005 were used as a starting point for manual calibration of the transient simulation. Hydraulic properties adjusted during the calibration process include horizontal hydraulic conductivity, vertical hydraulic conductivity between model layers, specific storage, specific yield, river conductance, drain conductance, general head boundary conductance, and recharge rates. After each change in one of these parameters, the simulation was run and simulated groundwater levels were compared to observed groundwater levels.

The model accuracy was calculated using the root mean square (RMS) error between actual hydraulic head measurements and model-generated hydraulic head at the end of each model run. Model accuracy was increased by minimizing the RMS error. The RMS error measures the absolute value of the variation between measured and simulated hydraulic heads at control points. The equation to calculate the RMS error is:

$$
\text { RMS error }=\sqrt{\frac{e_{1}^{2}+e_{2}^{2}+e_{3}^{2}+\ldots e_{n}^{2}}{n}}
$$

where

$e$ is the difference between the measured hydraulic heads and the simulated hydraulic heads,

and

$n$ is the number of control points.

The value of the RMS error used to determine if the model simulation was acceptable was based on the accuracy of waterlevel measurements. Water level measurement errors are discussed in Kelly (1996b) and the largest possible error is $1.5 \mathrm{~m}$.

Water levels measured in monitoring wells located near supply wells are closely related to the rate of pumping. The use of an average pumping rate instead of the actual pumping rate can introduce substantial error between a simulated and measured water level. The most likely instance when this would occur is when average annual well pumpage is used. A typical well-field pumping schedule involves varying well pumpage to meet water-supply demand. If the water level was measured when the nearby well was pumping, the simulated water-level altitude will be higher than the measured water level. If the well was not pumping, the simulated water level will be too low. This type of error is not easily quantified, but could be up to several meters if the measured well is close to the pumping well.

The Missouri River stage was measured at the USGS streamflow-gaging station (hereafter referred to as streamgage) at Kansas City (station number 06893000) to the nearest $0.003 \mathrm{~m}$. River stage was distributed among model cells using linear interpolation between gages along the midline of each river as described in Kelly (1996a). The maximum possible error for water-level measurements is the sum of the maximum errors caused by water-level measurement errors, measuringpoint altitude errors, and errors introduced by interpolation of river stage. The chance that the maximum error would occur for any water-level measurement is small. More likely to occur is a combination of errors of varying value and sign. However, knowledge of these errors and their magnitude is necessary to determine the appropriate constraints to assess model accuracy. The acceptable RMS errors for model calibration discussed in the following sections are less than the largest maximum measurement errors.

Quasi-steady-state conditions using synoptic water-level data, rainfall, and well pumping from January 1993 were calibrated for the original simulation to assess overall model geometry, confirm the conceptual model of groundwater flow, test the appropriateness of simulated boundary conditions and obtain approximate transmissivity and recharge arrays (Kelly, 1996a). Because the conceptual flow model, boundary conditions, and hydrologic assumptions assessed in the original quasi-steady-state calibration simulation are the same as those in the updated simulation, quasi-steady-state calibration of the updated simulation was not performed.

Actual steady-state conditions in the alluvial aquifer are unknown because of substantial variations in the stage of the Missouri River, variable and intermittent precipitation, and continuous well pumping. Initial conditions for the original transient calibration were not simulated for steady-state conditions but were obtained from quasi-steady-state conditions assumed by Kelly (1996a) based on saturated conditions in the alluvium from the 1993 flood as later described by Perry and others (1997). Hydraulic head for each active cell was set equal to the land-surface altitude to obtain the initial conditions. Setting hydraulic head equal to land surface was a reasonable estimate of hydraulic head for August 1993 when measured water levels were not available. However, hydraulic head in the alluvial aquifer in August 1993 was most likely substantially different than land surface at that time because of differences in water surface and land surface altitude in inundated areas, limited recharge from flood water because of the silt-clay cap at the top of the aquifer, and high recharge from the Missouri River through the river bed that intersects the highly permeable sands of the aquifer (Kelly, 1996a). The siltclay cap most likely limited recharge to the aquifer from flood inundation and the high stage in the Missouri River caused the increase in hydraulic head to propagate into the aquifer from the river into the aquifer as described in (Kelly, 2000).

Initial conditions for the updated transient calibration simulation were obtained from a quasi-steady-state simulation based on average annual river stage, average annual precipitation, and 1990 pumping. These quasi-steady-state conditions were considered valid for initial conditions of the updated transient calibration simulation because they result in a hydraulic head distribution that approximates the average of potential transient responses. Average 1990 pumping rates were representative of pumping from previous years, groundwater levels in the Missouri River alluvial aquifer respond to long term river stage conditions (Kelly, 2000), and average annual river stage and average annual rainfall conditions 
produce an average hydraulic head distribution. The transient calibration simulated groundwater flow from 1990 to 1993 before observed and simulated hydraulic head data were compared to allow the groundwater flow simulation to incorporate the previous 3 years of transient stresses into simulated hydraulic head distribution introduced by the quasi-steadystate intial conditions and reduce errors between simulated and observed water levels.

A comparison of the assumed hydraulic head distribution for August 1993 from the quasi-steady-state initial conditions used in the original simulation (hydraulic head equals land surface) to the hydraulic head distribution for August 1993 from the updated transient simulation indicate the August 1993 hydraulic head distribution provided by the updated simulation included transient responses to stresses that were not in the August 1993 hydraulic head distribution initial conditions (fig. 4). In the case of the Missouri River alluvial aquifer where steady-state conditions do not exist, the distribution of hydraulic head for the updated simulation is more realistic for the August 1993 conditions than setting the hydraulic head equal to land surface. A simulation flow budget for the original quasi-steady-state conditions is not available because initial conditions were assumed and not simulated. The updated quasi-steady-state initial conditions simulation flow budget for 1990 is shown in table 2.

Calibration to transient conditions between 1990 and 1999 for the updated simulation used the hydraulic head data collected during synoptic water-level measurements
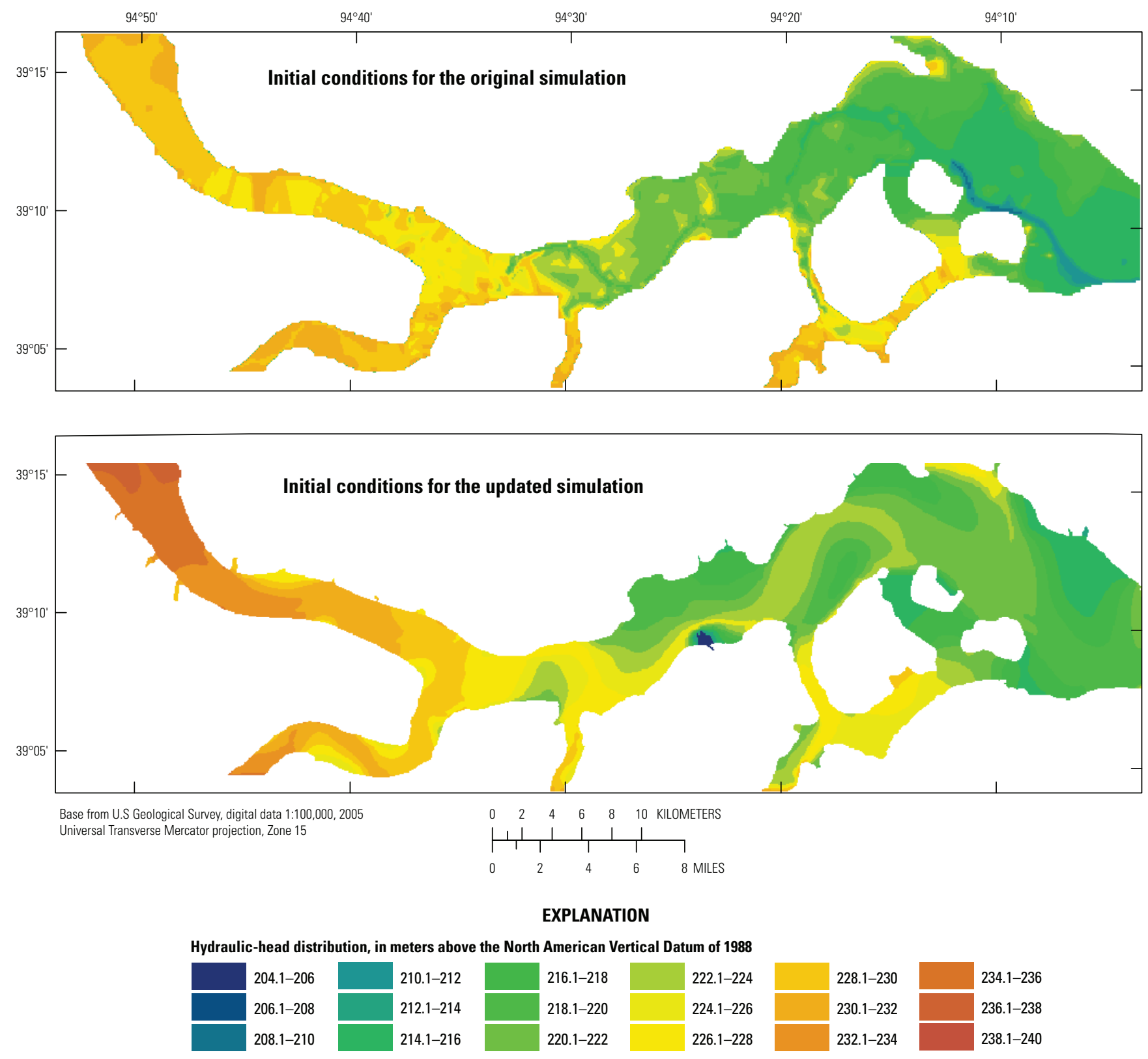

Figure 4. Assumed hydraulic head distribution for August 1993 initial conditions of the original simulation and simulated hydraulic head distribution of August 1993 for the updated transient simulation. 
Table 2. Updated quasi-steady-state initial conditions groundwater flow budget.

\begin{tabular}{|c|c|c|}
\hline \multirow{3}{*}{$\begin{array}{c}\text { Budget } \\
\text { component }\end{array}$} & \multicolumn{2}{|c|}{$\begin{array}{c}\text { Rates } \\
\text { (cubic meters per day) }\end{array}$} \\
\hline & \multicolumn{2}{|c|}{$\begin{array}{l}\text { Updated quasi-steady state simulation } \\
\text { for average annual river stage, average } \\
\text { annual recharge, and } 1990 \text { average } \\
\text { annual well pumping }\end{array}$} \\
\hline & In & Out \\
\hline Wells & 0 & 360,080 \\
\hline Drains & 0 & 1,125 \\
\hline River leakage & 882,229 & $1,328,036$ \\
\hline $\begin{array}{l}\text { Head dependent } \\
\text { boundaries }\end{array}$ & $1,037,500$ & 231,547 \\
\hline Recharge & 931 & 0 \\
\hline Total & $1,920,660$ & $1,920,788$ \\
\hline In-Out & & \\
\hline Percent discrepancy & & \\
\hline
\end{tabular}

from 123 wells in October 1993 and 98 wells in February 1994, continuously recorded water levels collected between 1995 and 1997 from 8 wells near Atherton (figs. 1, 4 ), and quarterly to annual water-level measurements collected between 1997 and 1999 from 69 monitoring wells near the Independence well field. Locations where water levels were measured are shown in figure 5. Water-level altitudes for synoptic water-level measurements collected during October 1993 and February 1994 and quarterly to annual water-level measurements collected during 1997 through 1999 from 69 monitoring wells near the Independence well field are listed in table 3 , at the back of this report. Continuously recorded water levels collected during 1995 through 1997 from wells near Atherton are available online from the USGS National Water Information System at the URL http://nwis.waterdata.usgs.gov/mo/nwis/gw. Mean daily water-level data can be retrieved for each of these wells using the USGS site number listed in table 4.

The updated transient calibration simulation used 3,379 daily stress periods to simulate groundwater flow in the model area from October 1, 1990 to December 31, 1999. The stage of the Missouri River has a large effect on groundwater flow in the alluvial aquifer and daily stress periods were needed to account for the frequent changes in Missouri River stage. New river stage and rainfall data were obtained from streamgages and rain gages listed in Kelly (1996a). Well pumpage data for the Independence well field were obtained from the Independence Water Department (City of Independence, written commun., 2008). Average annual well pumpage for the Independence supply wells was used from October 1, 1990 to December 31, 1996. Average monthly well pumpage for the Independence supply wells was used from January 1, 1997 to December 31, 1999. Average annual well pumpage for other wells in the updated transient calibration simulation was based on the best available information (Missouri Department of Natural Resources, 1991; 1996; 1997; 1998; 2001). Layer, row, column and well pumpage for 151 supply wells used in the updated transient calibration simulation are listed in table 5, at the back of this report. Mean daily Missouri River altitude at the USGS streamgage at Kansas City from October 1, 1990 to December 31, 1999 is shown in figure 6. Daily rainfall for the same period is shown in figure 7 .

Results of the original and updated calibration simulations of January 1992, October 1993, and January 1994 conditions are compared to ensure the updated transient simulation replicates the quasi-steady-state conditions described in Kelly (1996a) and matches the previous transient calibration. Quasisteady-state groundwater flow was simulated for January 1992 conditions and transient groundwater flow was simulated from August 1993 to February 1994, for the original calibration. The quasi-steady-state simulation was calibrated to hydraulic head data from synoptic water-level measurements from 123 wells in January 1993 and the transient simulation was calibrated to hydraulic head data from synoptic water-level measurements from 123 wells in October 1993 and 98 wells in February 1994 (Kelly, 1996a). The RMS error in simulated hydraulic head was $1.15 \mathrm{~m}$ for the original quasi-steady-state calibration, and $0.71 \mathrm{~m}$ for October 1993 and $0.8 \mathrm{~m}$ for February 1994 for the original transient calibration (Kelly, 1996a). The RMS error calculated for the updated transient calibration simulation was $1.54 \mathrm{~m}$ for the January 1992 water-level data, $0.76 \mathrm{~m}$ for the October 1993 water-level data, and $0.99 \mathrm{~m}$ for the February 1994 water-level data. The overall RMS error for the updated transient calibration simulation was $0.61 \mathrm{~m}$. The RMS error calculated using 2,512 daily waterlevel observations for wells near Atherton and 239 quarterly to annual water-level observations from 64 monitoring wells near the Independence well field was $0.44 \mathrm{~m}$ for the updated transient calibration simulation. These values are less than the maximum measurement errors and indicates the acceptability of the calibration. Daily water-level observations and simulated equivalents are shown for wells near Atherton (fig. 8). Quarterly and annual water-level observations and simulated equivalents are shown for Independence monitoring wells with three or more measurements in figure 9. The results of the comparison indicates that the updated calibration simulation reproduces the quasi-steady-state conditions in 1993 and that the initial conditions from 1990 used in the updated simulation appear reasonable.

In the original model, the distribution of lithology (clay, silt, sand, and gravel) was used to distribute values of hydraulic conductivity, the ratio of horizontal to vertical hydraulic conductivity, specific storage, specific yield, and porosity within each model layer. These aquifer property values were associated with a specific lithology and assigned to cells in the model based on the lithology of the cell. To simplify the updated model without losing important details and facilitate model calibration, aquifer property values were associated with a specific lithology and assigned to cells in the updated model based on the lithology of the cell. The resulting distribution of values were then categorized into groups of cells with similar values called zones. A single aquifer property value was assigned to each zone. Although the overall distribution of aquifer properties are similar between the original and updated 

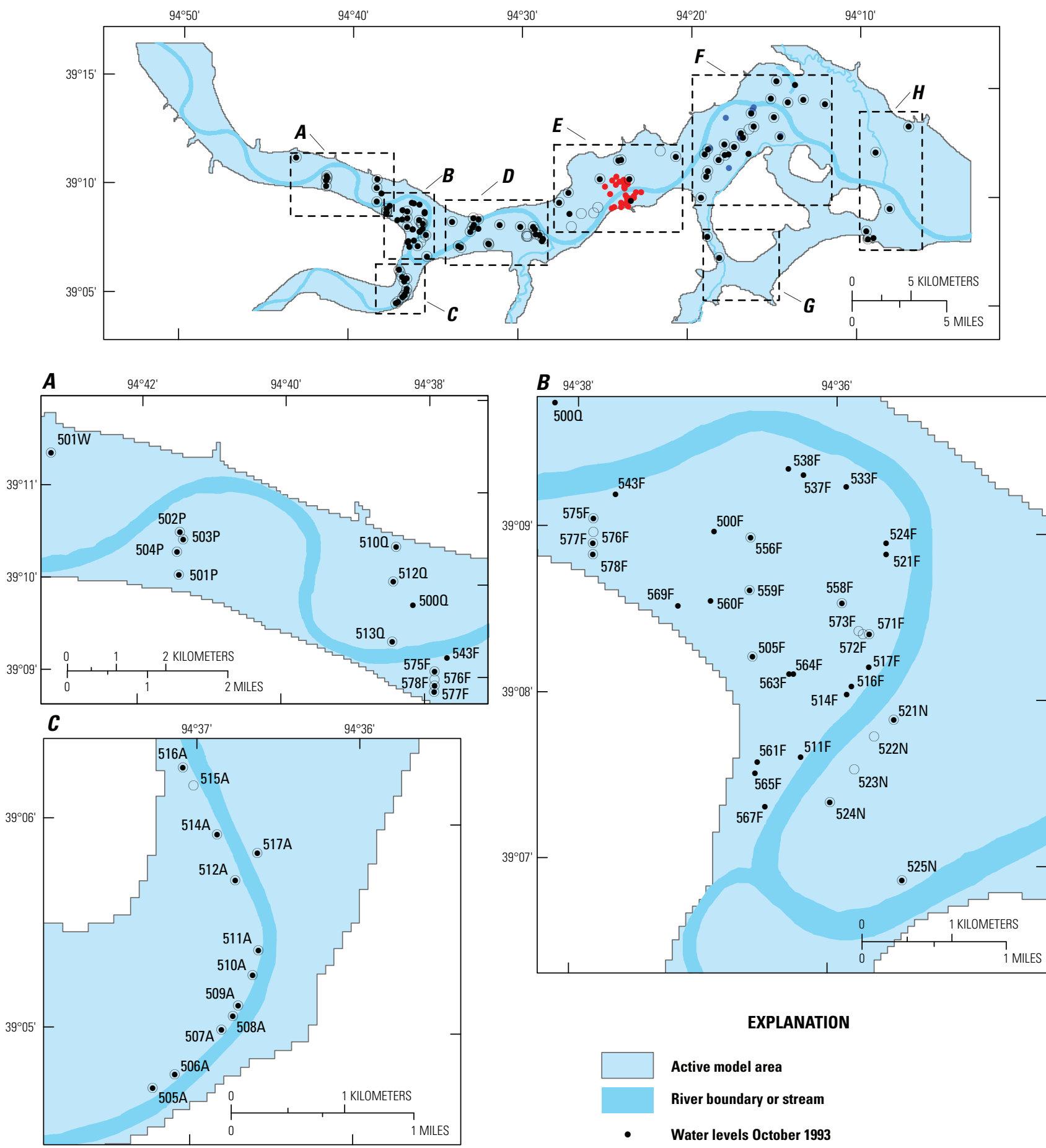

\section{EXPLANATION}

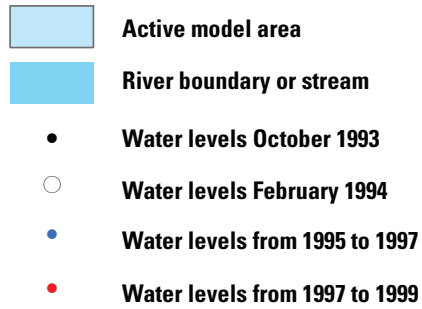

Water-level altitudes for synoptic water-level measurements during October 1993 and February 1994 and quarterly to annual water-level measurements collected between 1997 and 1999 are listed in table 3 using the well identifier shown next to each water-level location.

Figure 5. Locations where water levels were measured. 

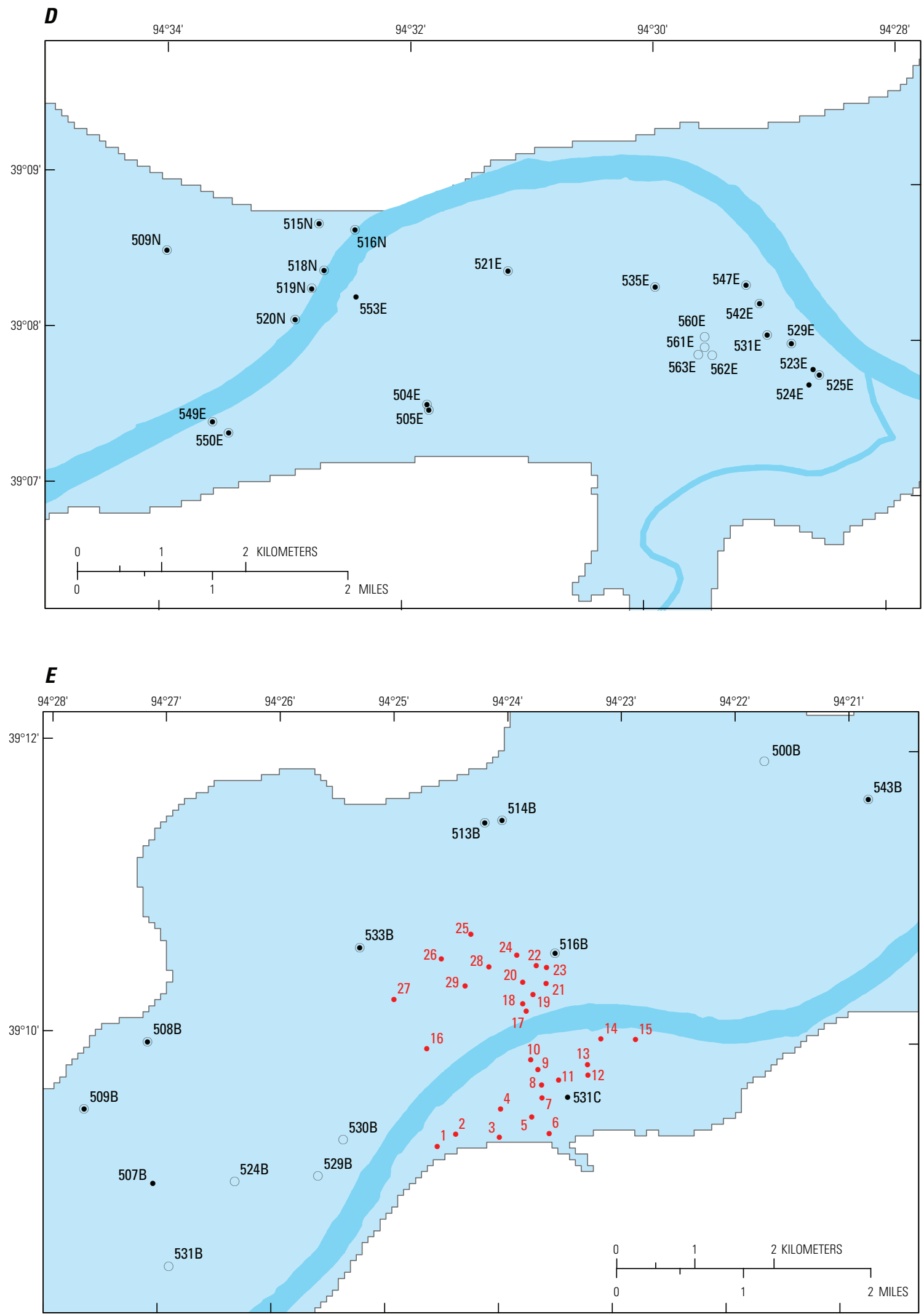

Figure 5. Locations where water levels were measured.-Continued 


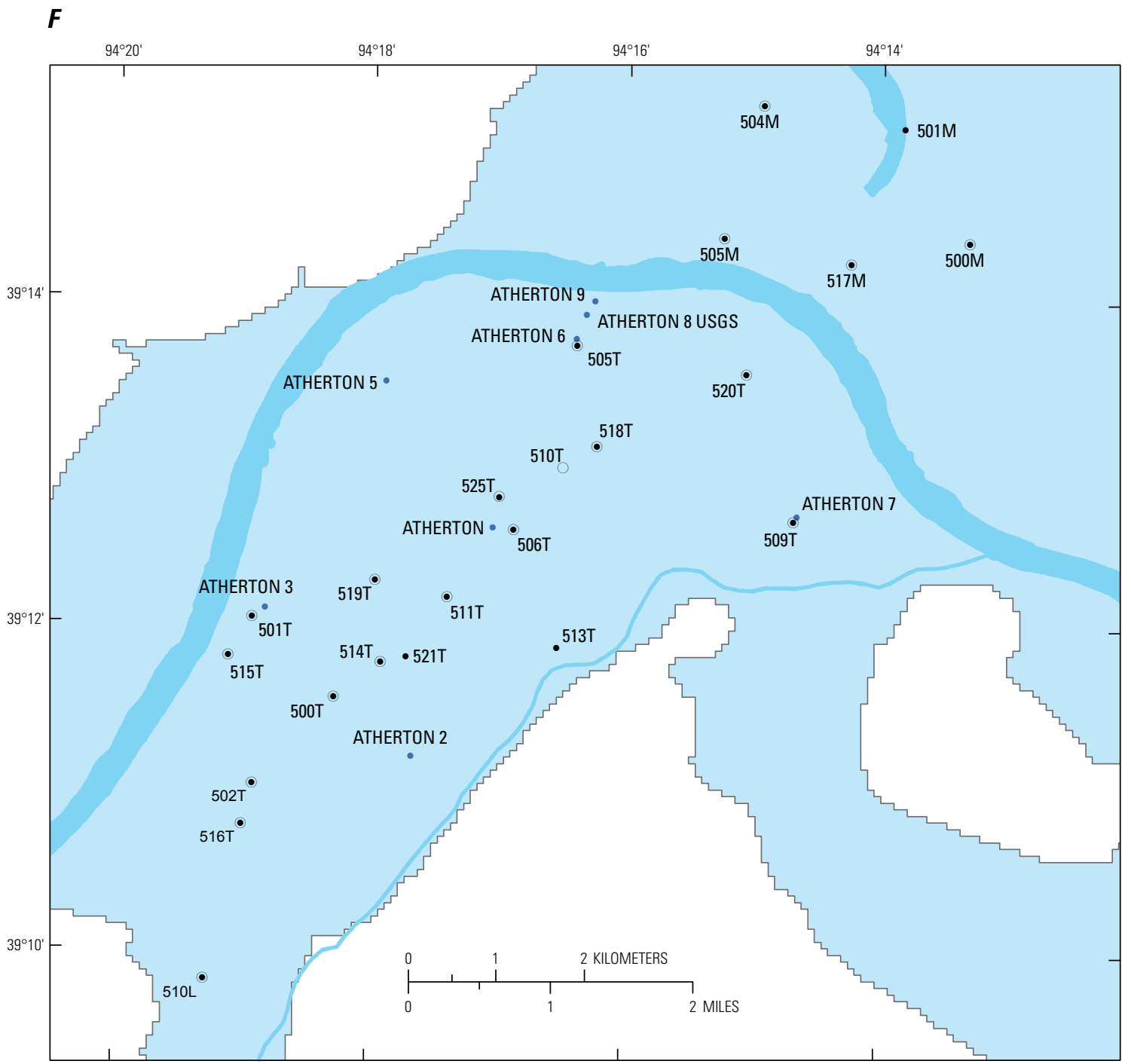

Figure 5. Locations where water levels were measured.-Continued 

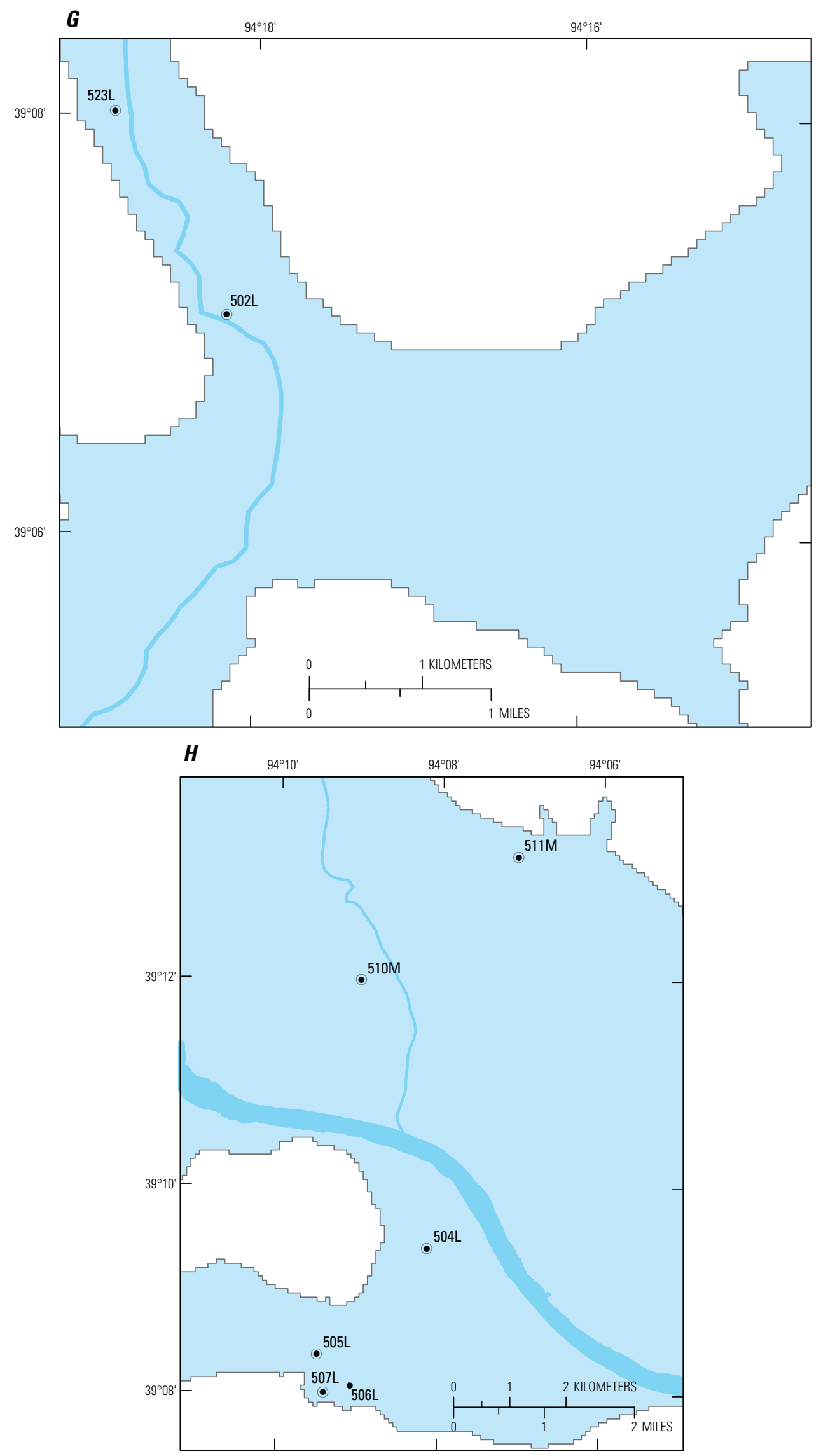

Figure 5. Locations where water levels were measured.-Continued 
Table 4. U.S. Geological Survey site numbers for wells near Atherton, Missouri.

[USGS, U.S. Geological Survey]

\begin{tabular}{lc}
\hline $\begin{array}{c}\text { Site name } \\
\text { (fig. 4) }\end{array}$ & Site number \\
\hline Atherton 2 & 391112094174001 \\
Atherton 3 & 391206094185001 \\
Atherton & 391236094170201 \\
Atherton 5 & 391329094175501 \\
Atherton 6 & 391343094162401 \\
Atherton 7 & 391346094162401 \\
Atherton 8-USGS & 391354094161901 \\
Atherton 9 & 391400094161601 \\
\hline
\end{tabular}

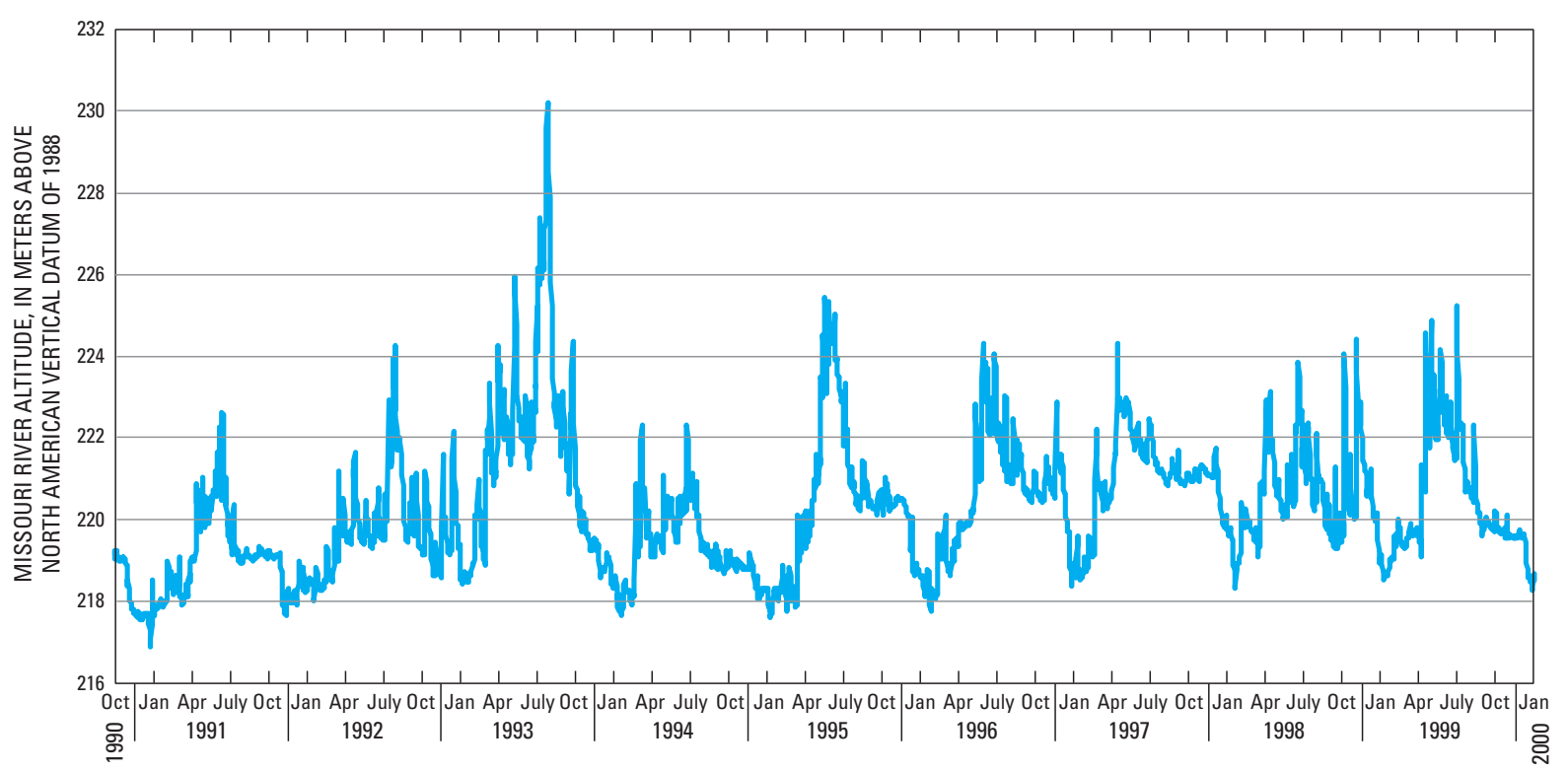

Figure 6. Daily Missouri River altitude at the U.S.Geological Survey streamgage at Kansas City, Missouri (site number 06893000) from October 1, 1990 to December 31, 1999 (observation at 8:00 AM).

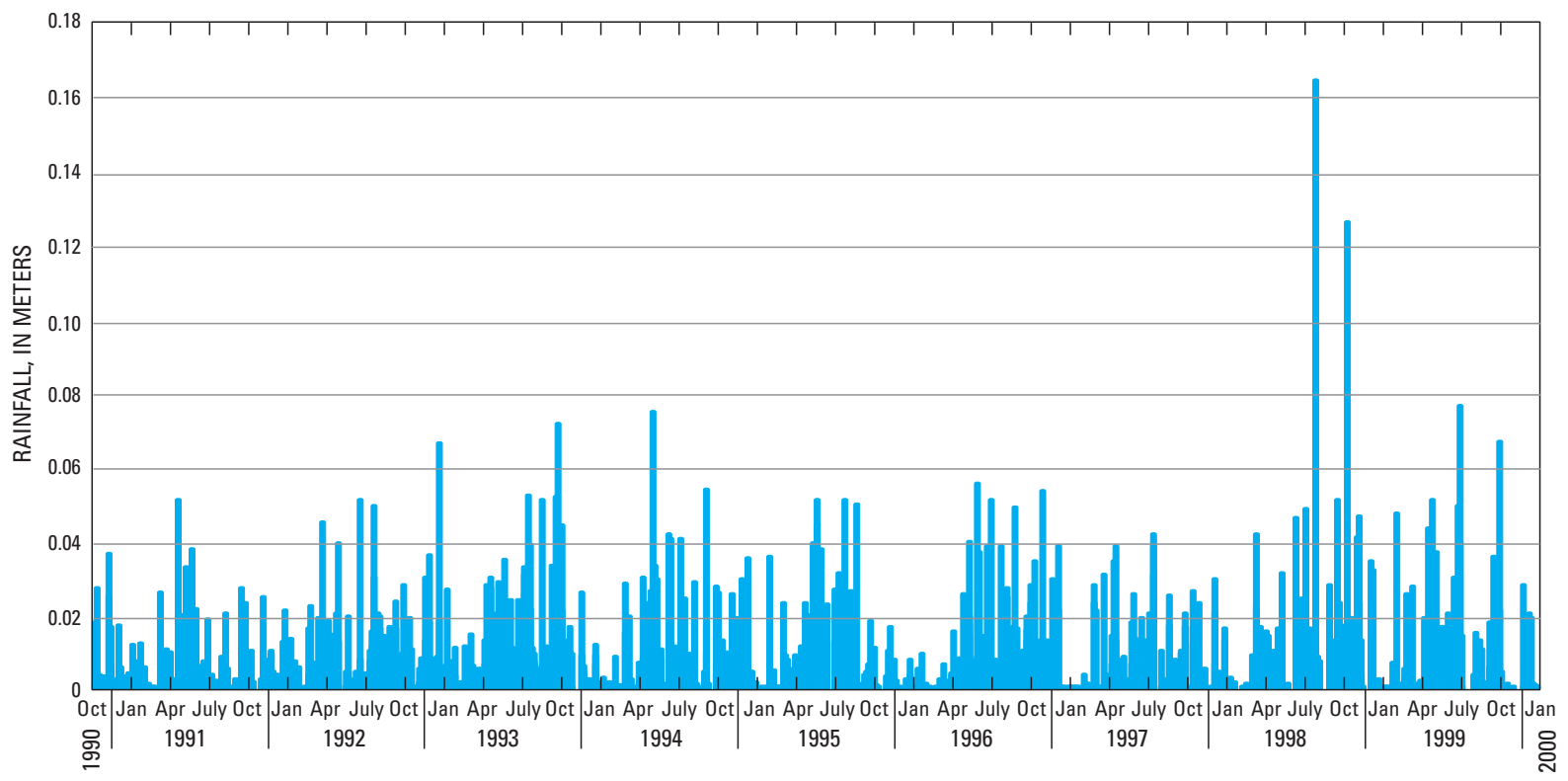

Figure 7. Daily rainfall used for groundwater simulations from October 1, 1990 to December 31, 1999. 

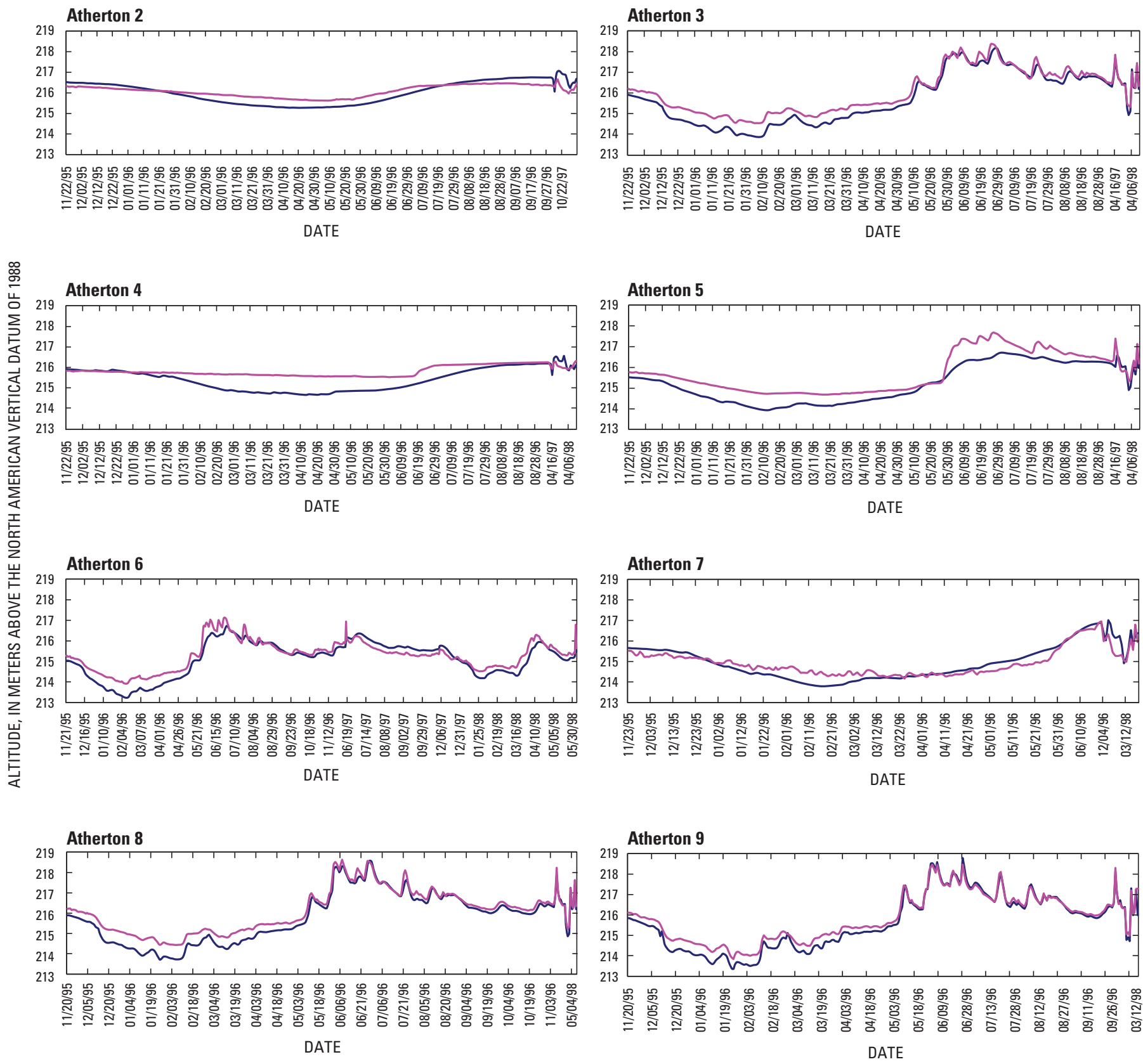

EXPLANATION

Observed value

Simulated equivalent

Figure 8. Daily water-level observations and simulated equivalents for wells located near Atherton, Missouri. 

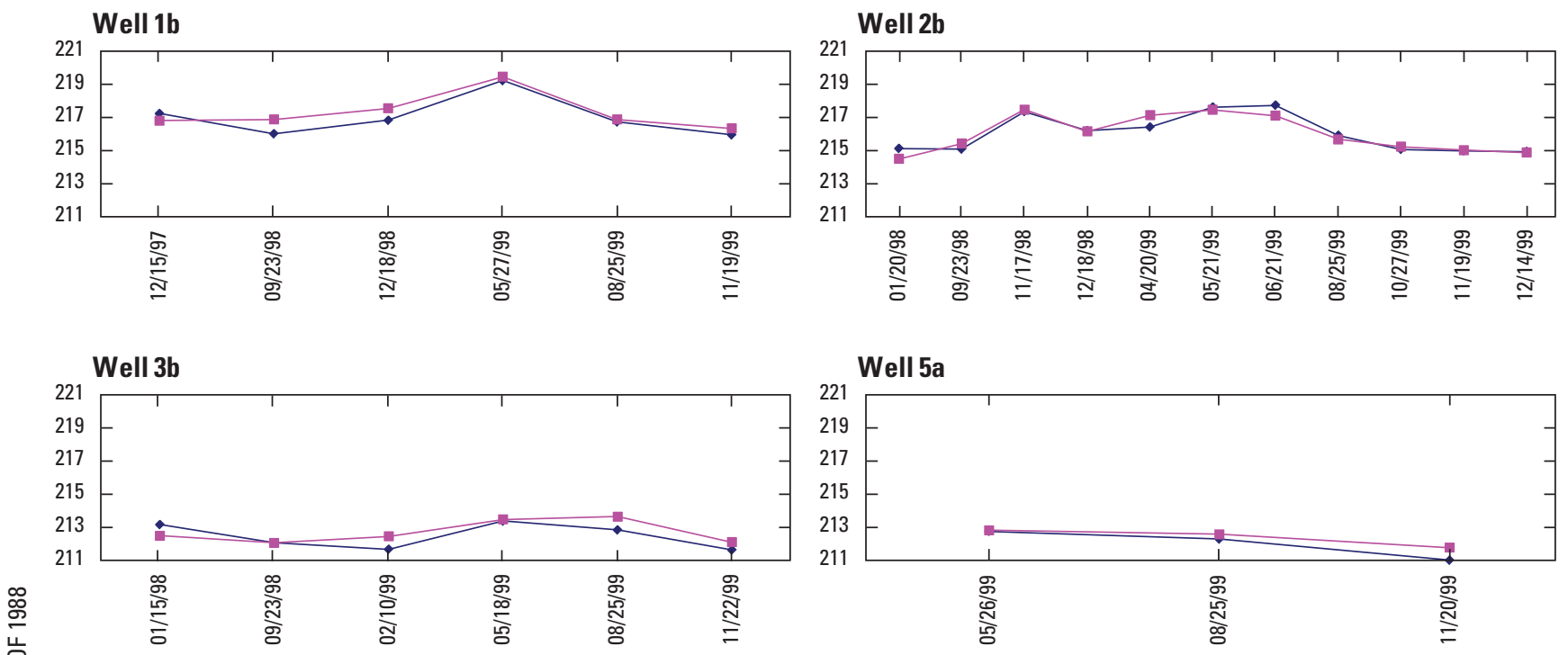

Well 5b

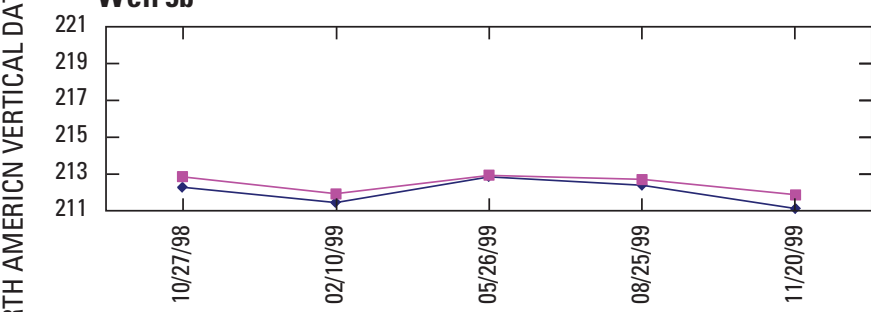

Well 6a
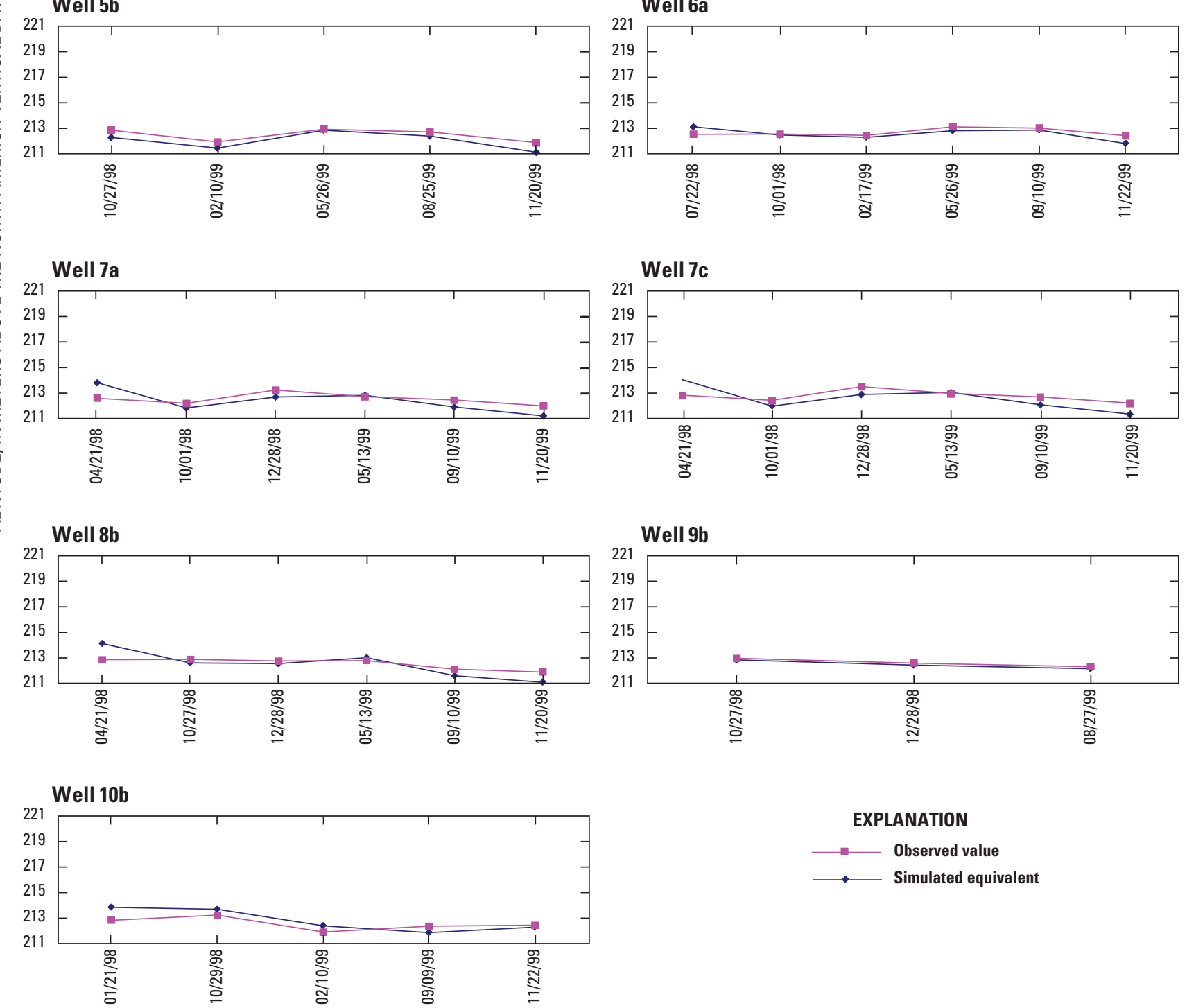

EXPLANATION

—- Observed value

Simulated equivalent

Figure 9. Quarterly and annual water-level observations and simulated equivalents for Independence monitoring wells with 3 or more measurements. 

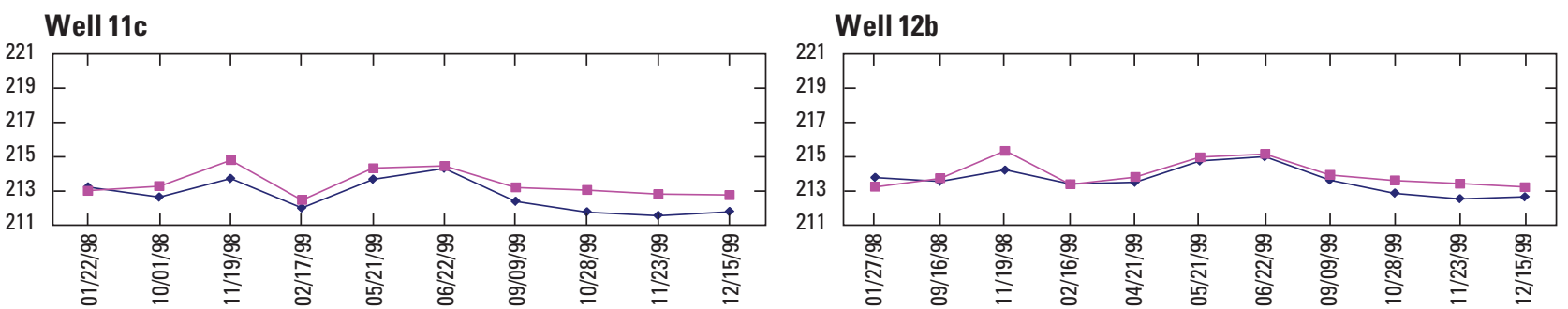

Well 13b

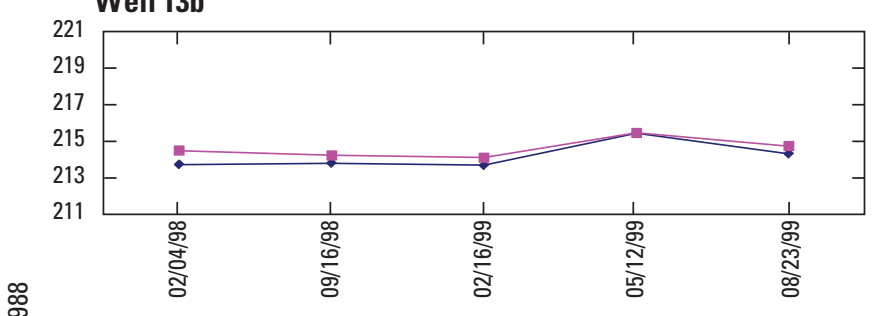

Well 14a
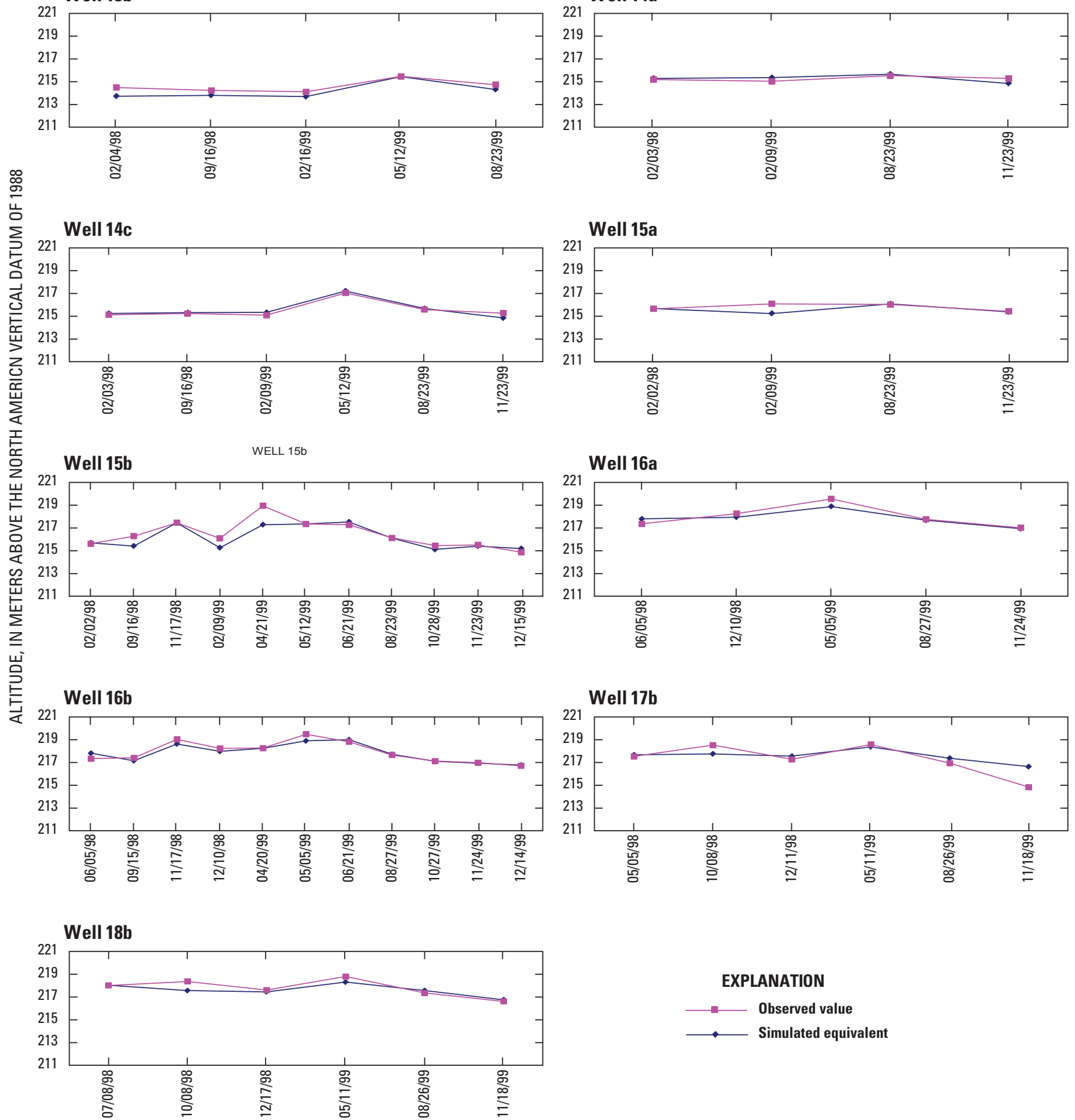

Figure 9. Quarterly and annual water-level observations and simulated equivalents for Independence monitoring wells with 3 or more measurements.-Continued 

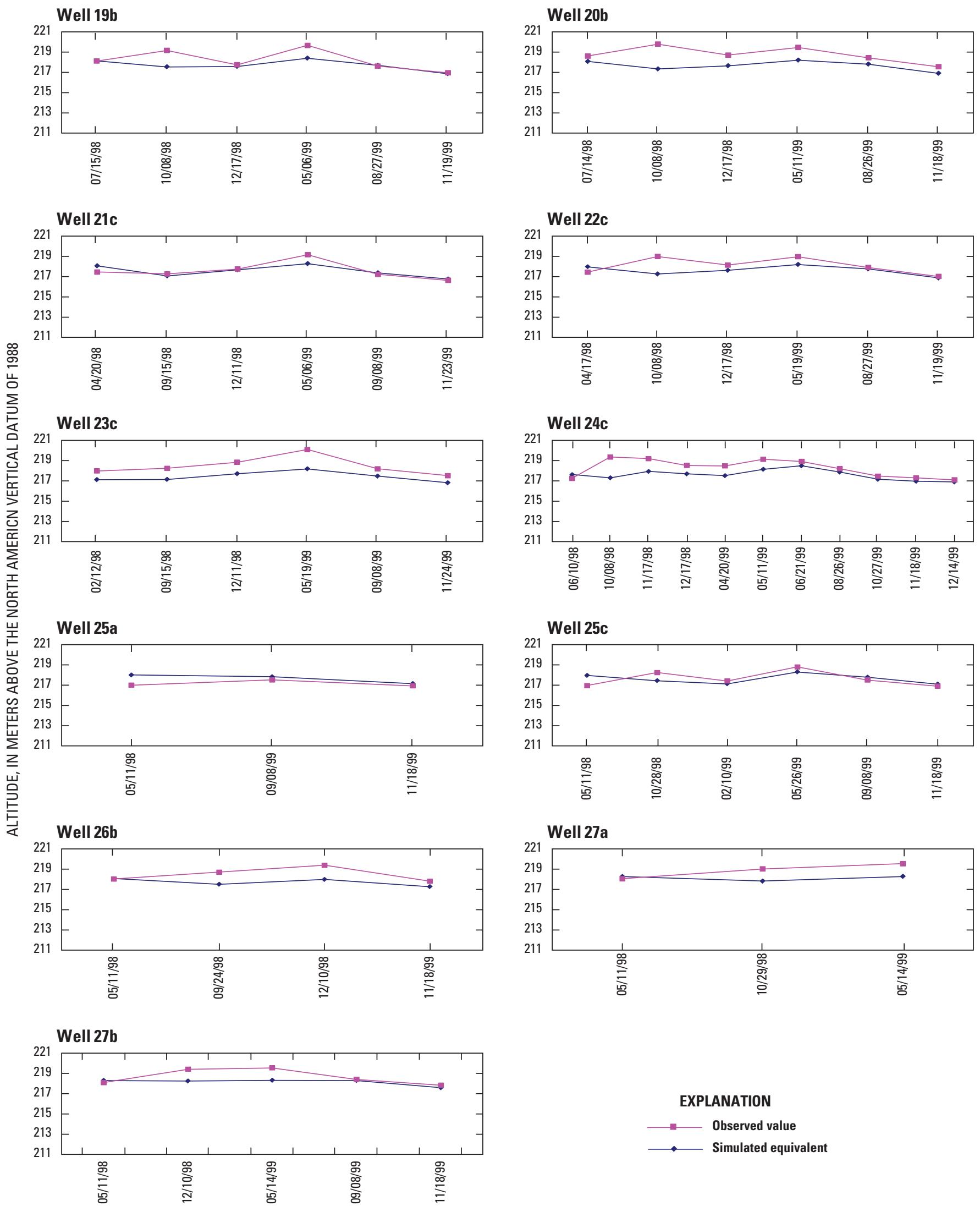

EXPLANATION

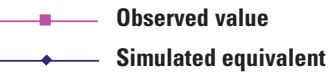

Figure 9. Quarterly and annual water-level observations and simulated equivalents for Independence monitoring wells with 3 or more measurements.-Continued 
models, the process of assigning single values to zones in the updated model changed the distribution of some aquifer properties. Nomenclature for parameters was based on the type of parameter, the layer number, and the zone number (if more than one zone per layer). For example, the parameter designation HK2_1 denotes horizontal hydraulic conductivity for layer 2, zone 1 and VK34 denotes the ratio of horizontal to vertical hydraulic conductivity for layers 3 and 4 .

Some parameters represented hydraulic properties that are not distributed as zones. These properties include riverbed conductance (RPARM), drain conductances (DRN1, DRN2, and DRN3), well pumpage rate, and rate of flow across general head boundaries (GHBPARM). Each of these properties was distributed within the model using the layer, row, and column number of each cell. Riverbed conductance was calculated for each cell that contained a river using the horizontal hydraulic conductivity of the cell, the area of the river within the cell, and the adjustment factor as described in Kelly (1996a). The RPARM parameter value was multiplied by the calculated conductance for each cell. The drain parameter values for DRN1, DRN2, and DRN3 corresponded to the drain-size class adjustment factor as described in Kelly (1996a). The GHBPARM parameter value approximated the cross-sectional area of the cell at each boundary in square meters and was multiplied by the horizontal hydraulic conductivity of each general head boundary cell. Parameter names, types, layer and zone numbers, updated parameter value, original range of values, and updated porosity, and original porosity range are listed in table 6 . The distribution of horizontal hydraulic conductivity for the model is shown in figure 10. The distribution of specific yield for layer 1 is shown in figure 11 .

Recharge was applied to the topmost active cell in each vertical column and was varied areally and temporally as a percentage of rainfall. The areal distribution of recharge as a percentage of rainfall is shown in figure 12, and the distribution is based on the vertical hydraulic conductivity values of the soil in each cell (Kelly and Blevins, 1995). Recharge also varied temporally by the month of the year for the transient calibration. Daily recharge as a percentage of rainfall was 80 percent in December, January, and February; 60 percent in March; 50 percent in April; 10 percent in May; 0.1 percent in June, July, August, and September; and 40 percent in October and November. For the transient calibration period, total recharge (varied both areally and temporally) was about 8.8 percent of the total budget and was 0.915 percent of total rainfall.

\section{Sensitivity Analysis}

Sensitivity analyses were used to assess the response of the updated simulation to changes in various input parameter values. The model is considered more sensitive to a parameter when a change of the parameter value results in a relatively large change in the simulated hydraulic head. When the model is sufficiently sensitive to a parameter, the value of that parameter may be more accurately determined during model calibration because relatively small changes to the parameter value results in large changes in hydraulic head. If a change of parameter value results in a relatively small change in the simulated hydraulic head distribution, the model is considered insensitive to that parameter and the value of that parameter is less certain.

Sensitivities for model parameters and for recharge and well pumpage were calculated with the steady-state 2007 base simulation by doubling each parameter value while all other parameters were set at the calibrated value. The mean of the resulting simulated hydraulic head distribution was compared to the mean of the calibrated simulated hydraulic head distribution. The model is most sensitive to well pumpage, followed by the parameters HK34_6, HK34_7, HK2_6, HK34_5, HK2_4, and RPARM, and recharge (table 6). When each value was doubled, the resulting mean water-level change was greater than or equal to $0.01 \mathrm{~m}$. Changes in the hydraulic head distribution are shown in figure 13.

Sensitivity of the simulated water levels to perturbations in model parameter values was largest near areas where hydraulic stresses to the model were largest (fig. 12). The simulation is most sensitive to the rate of well pumpage especially near supply wells as shown in figure 13. Doubling the well pumpage changed hydraulic heads from the original simulation from 0 to $-5.95 \mathrm{~m}$. Doubling the hydraulic conductivity parameters HK34_6, HK34_7,HK2_6, HK34_5, and HK2_4 changed hydraulic heads from 1.03 to $-0.19 \mathrm{~m}$ and decreased hydraulic gradients in general by allowing greater groundwater flow across a unit cross-sectional area (fig. 12). This resulted in increases in hydraulic head near well fields by allowing more groundwater flow to supply wells and decreased hydraulic heads in areas farther away from supply wells by allowing more groundwater to drain into rivers and drains. The relative changes in simulated water levels between the different simulations where hydraulic conductivity values were doubled reflected the distribution of those parameter zones within the model. Doubling the river conductance (RPARM; fig. 12) resulted in a similar change in hydraulic head as did doubling recharge (fig. 12). Hydraulic head changes ranged from 0.61 to $-0.15 \mathrm{~m}$ (from the steady-state 2007 base simulation) when recharge was doubled. Increasing river conductance increased groundwater levels near supply wells because more groundwater was available to supply the wells from the rivers. In areas removed from the effects of well pumpage, groundwater levels decreased with increased river conductance because more groundwater drained into the rivers and drains. Increasing recharge supplied more groundwater to supply wells and caused increased hydraulic head near well fields.

\section{Model Limitations}

A groundwater model is a simplified approximation of actual aquifer properties and conditions. The accuracy of the results depends on the accuracy and completeness of the input data and conceptual flow system. The groundwater flow model for this study was constructed with available historical and site specific hydrologic data to determine groundwater flow 
Table 6. Parameter names, types, layer and zone number, updated value, original range of values, porosity, and original porosity range.

[HK, horizontal hydraulic conductivity; m/day, meter per day; VK, ratio of horizontal to vertical hydraulic conductivity; SS, specific storage; SY, specific yield; DC, drain conductance; GHBC, general head boundary conductance; RIV, riverbed conductance; <, less than; - not applicable]

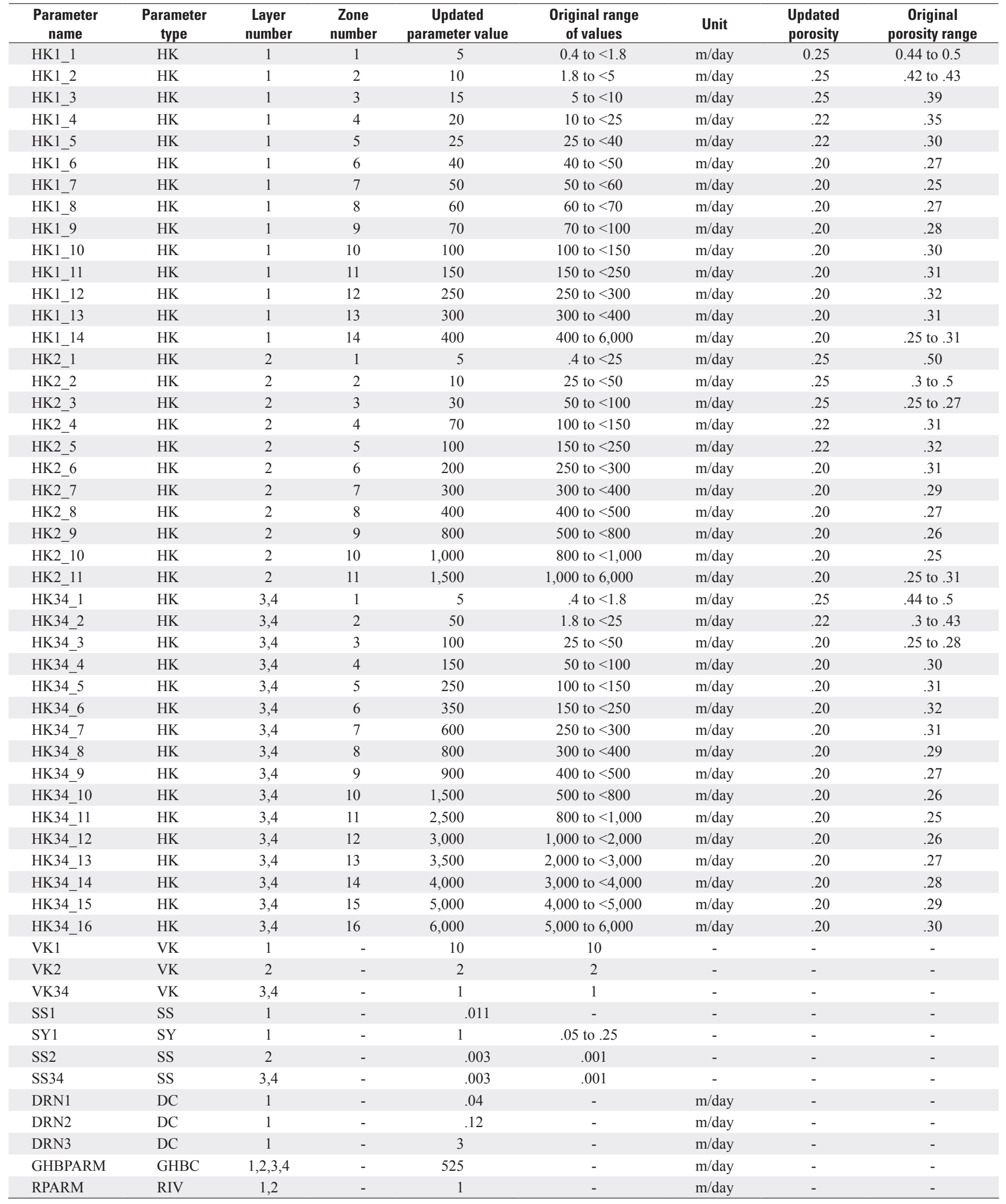




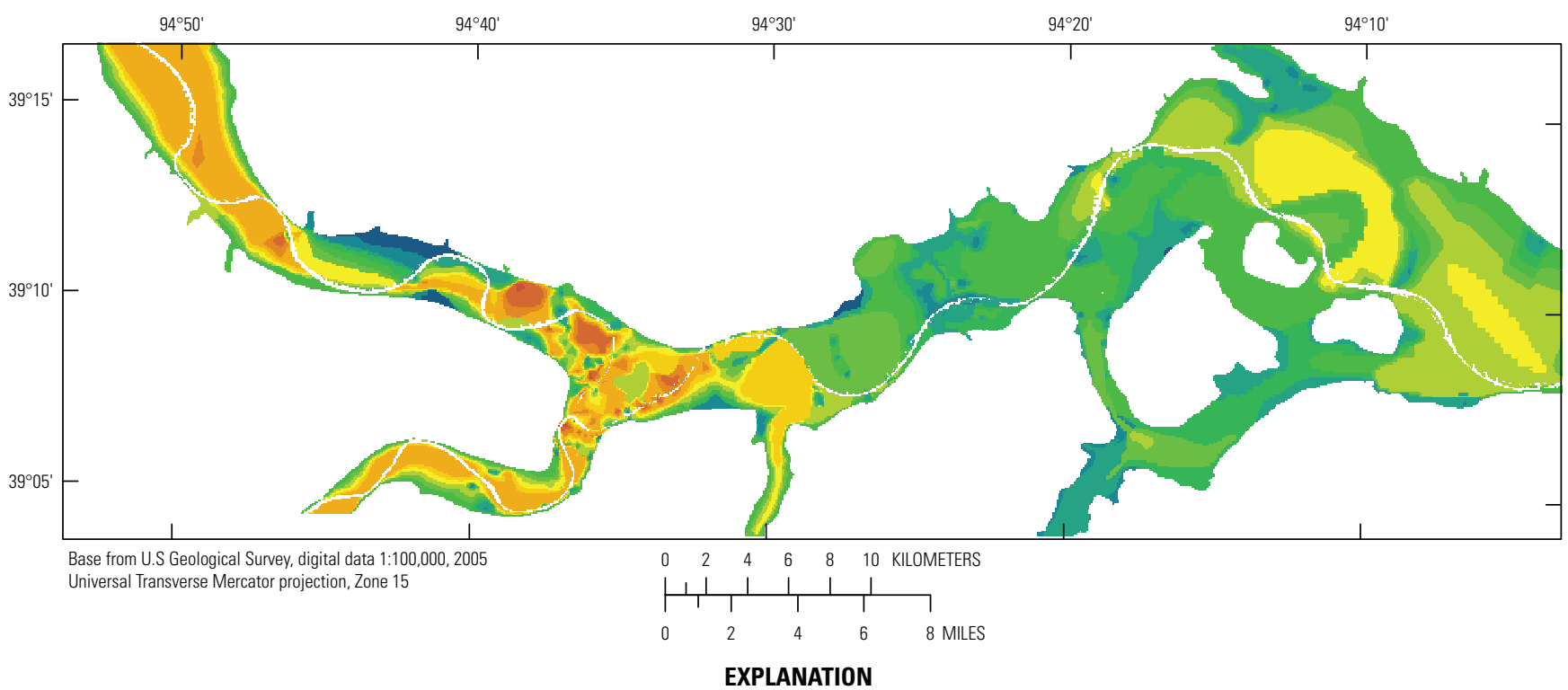

Horizontal hydraulic conductivity layer 1-Parameter name_meters per day

\begin{tabular}{|l|l|l|}
\hline HK1_1, & HK1_6, 40 & HK1_11, 150 \\
\hline HK1_2, 10 & HK1_7, 50 & HK1_12, 250 \\
\hline HK1_3, 15 & HK1_8,60 & HK1_13,300 \\
\hline HK1_4, 20 & HK1_9, 70 & HK1_14, 400 \\
\hline HK1_5, 25 & HK1_10, 100 & \\
\hline
\end{tabular}

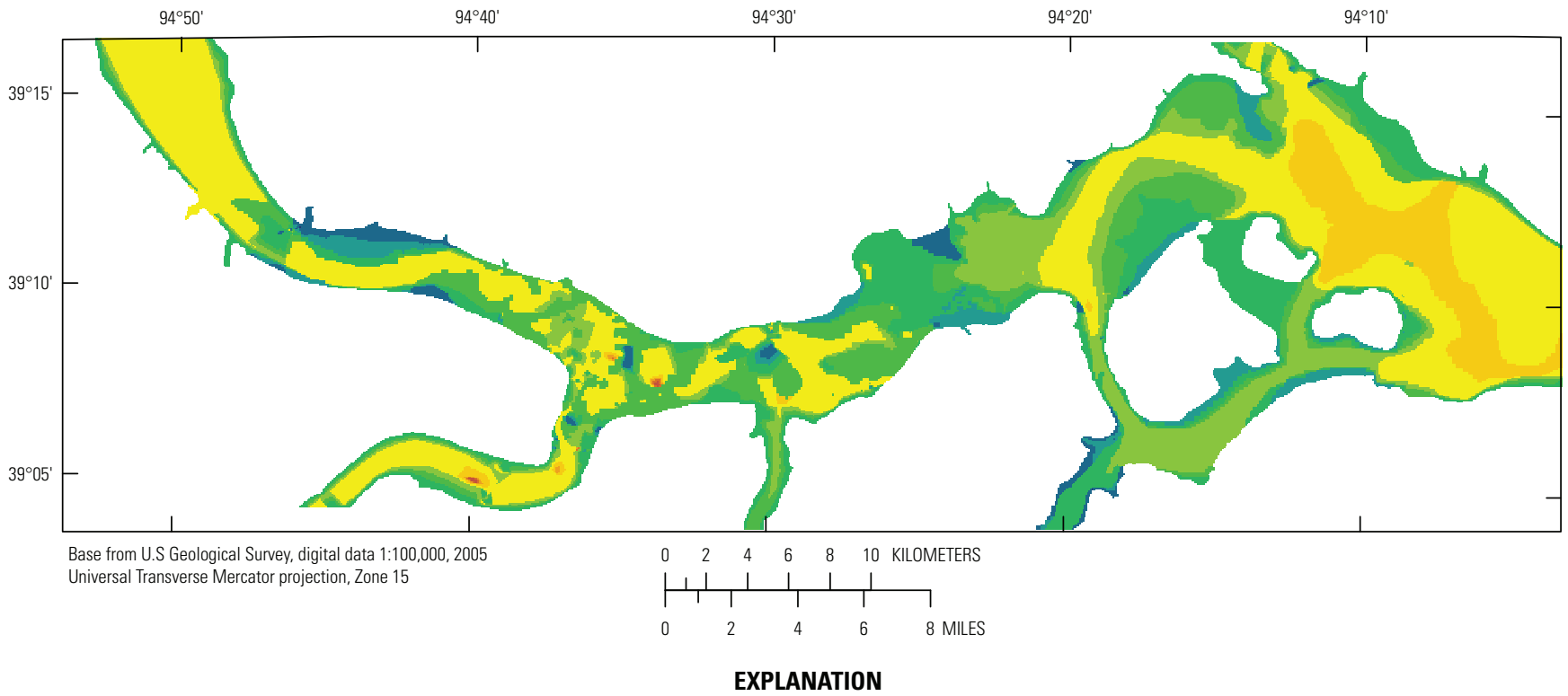

Horizontal hydraulic conductivity layer 2-Parameter name_meters per day

\begin{tabular}{lll} 
HK2_1, & HK2_5, 100 & HK2_9, 800 \\
HK2_2, 10 & HK2_6, 200 & HK2_10, 1,000 \\
HK2_3, 30 & HK2_7, 300 & HK2_11, 1,500 \\
HK2_4, 70 & HK2_8, 400 & \\
\hline
\end{tabular}

Figure 10. Horizontal hydraulic conductivity for each model layer. 


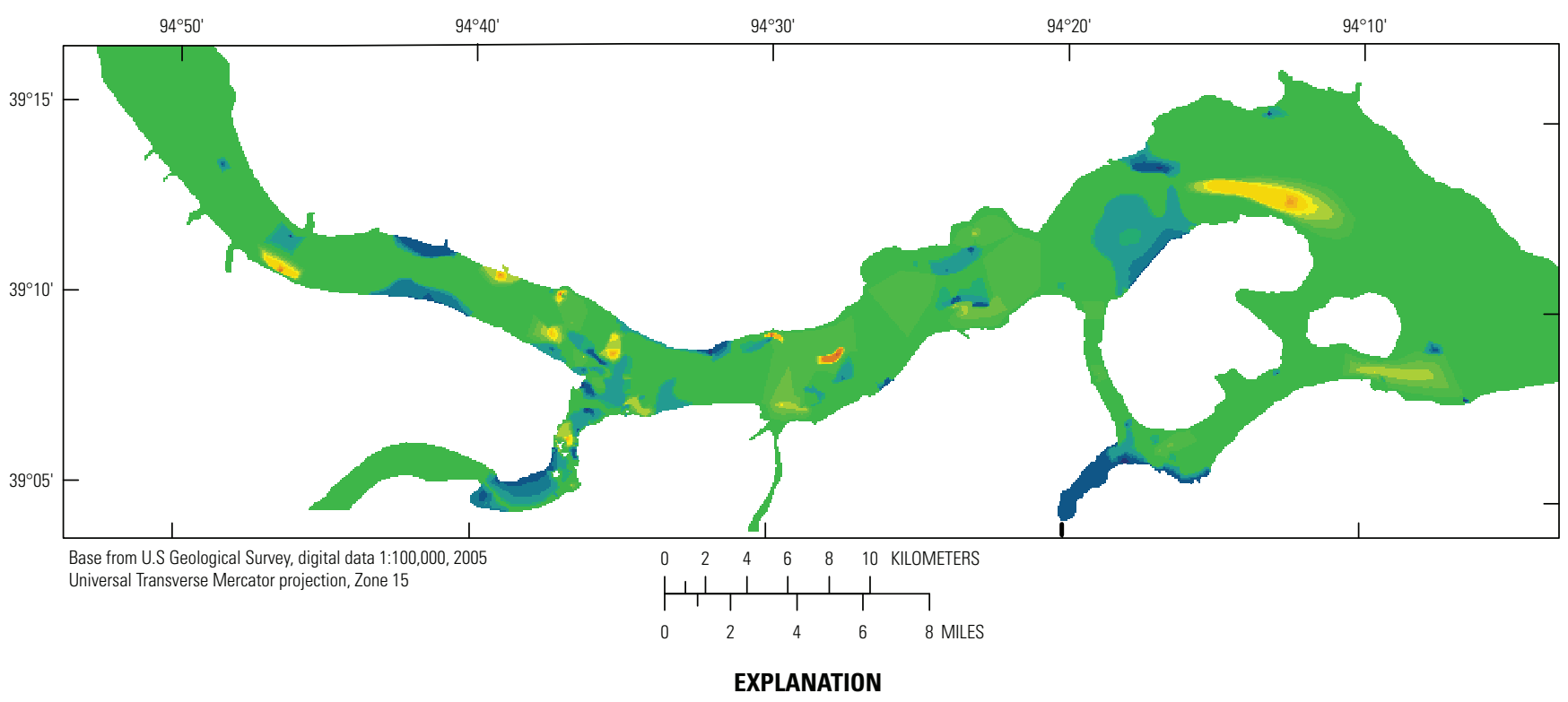

Horizontal hydraulic conductivity layer 3-Parameter name_meters per day

\begin{tabular}{ll|l|l}
\hline HK34_1, 5 & HK34_5, 250 & HK34_9, 900 & HK34_13, 3,500 \\
\hline HK34_2, 50 & HK34_6, 350 & HK34_10, 1,500 & HK34_14, 4,000 \\
\hline HK34_3, 100 & HK34_7, 600 & HK34_11, 2,500 & HK34_15, 5,000 \\
\hline HK34_4, 150 & HK34_8, 800 & HK34_12, 3,000 & HK34_16, 6,000
\end{tabular}

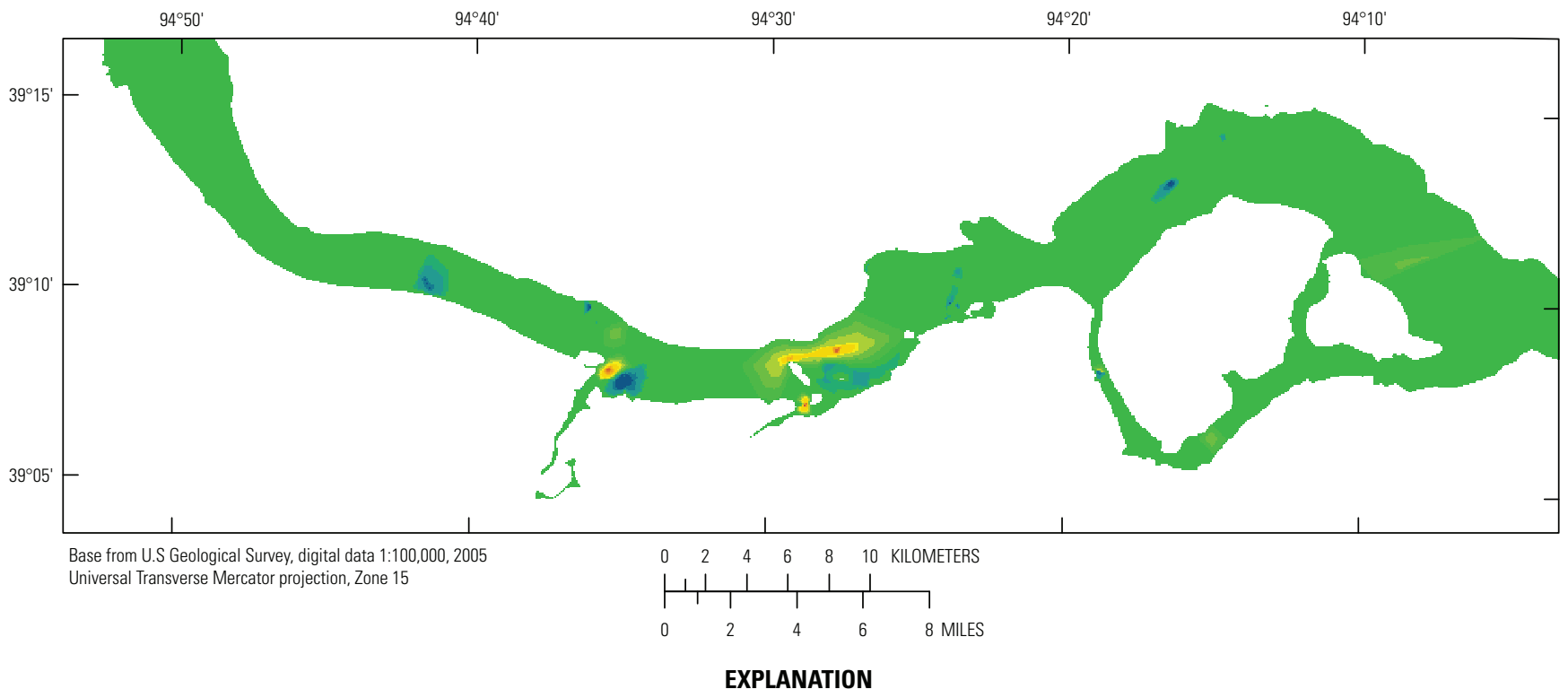

Horizontal hydraulic conductivity layer 4-Parameter name_meters per day

\begin{tabular}{lllll}
\hline HK34_1, 5 & HK34_5, 250 & HK34_9, 900 & HK34_13, 3,500 \\
\hline HK34_2, 50 & HK34_6, 350 & HK34_10, 1,500 & HK34_14, 4,000 \\
\hline HK34_3, 100 & HK34_7, 600 & HK34_11, 2,500 & HK34_15, 5,000 \\
\hline HK34_4, 150 & HK34_8, 800 & HK34_12, 3,000 & HK34_16,6,000
\end{tabular}

Figure 10. Horizontal hydraulic conductivity for each model layer.—Continued 


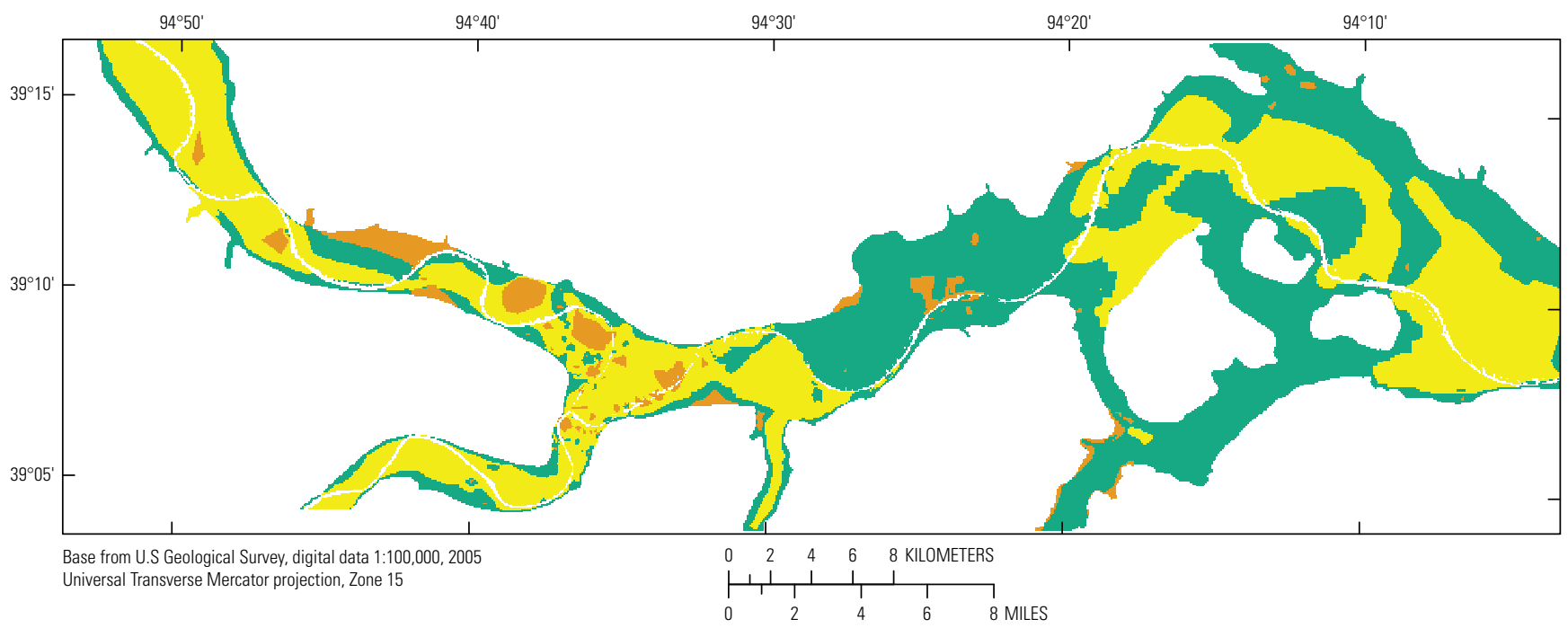

\section{EXPLANATION}

Specific yield layer 1

\begin{tabular}{|l|l|}
\hline & 0.18 \\
\hline & 0.19 \\
\hline & 0.20 \\
\hline
\end{tabular}

Figure 11. Specific yield for model layer 1.

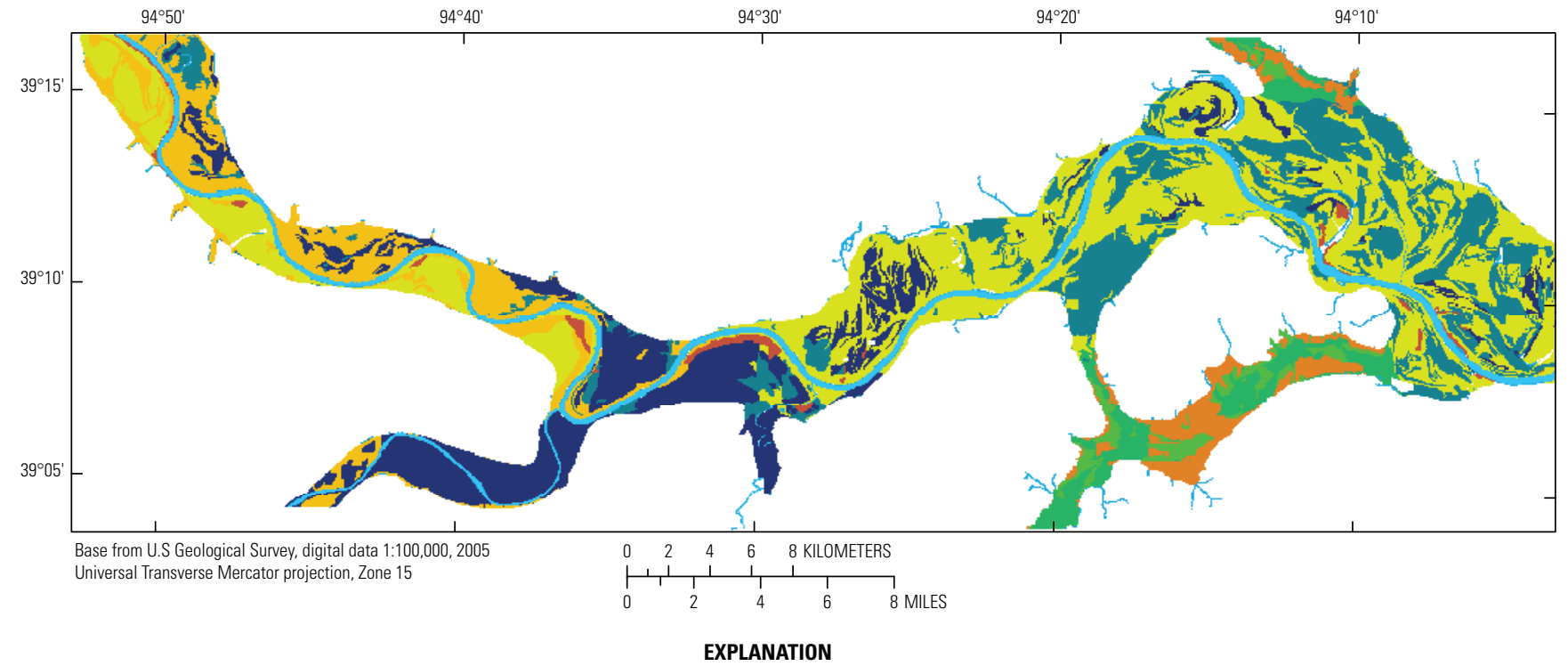

Recharge as a percentage of rainfall

\begin{tabular}{|l|l|l|l|l|}
\hline 0.1 & 0.4 & 1 & 3.8 \\
\hline 0.2 & 0.5 & 2 & 5 \\
\hline
\end{tabular}

Figure 12. Areal distribution of recharge as a percentage of rainfall. 


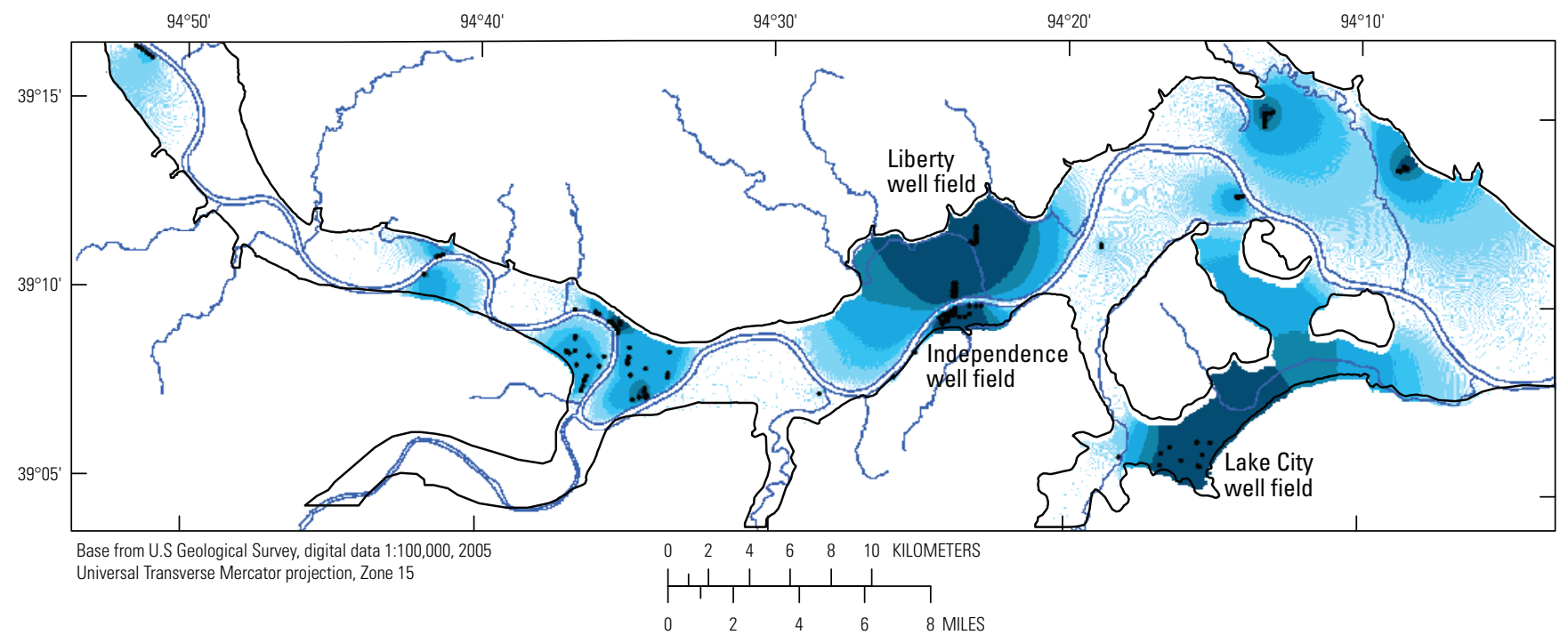

EXPLANATION
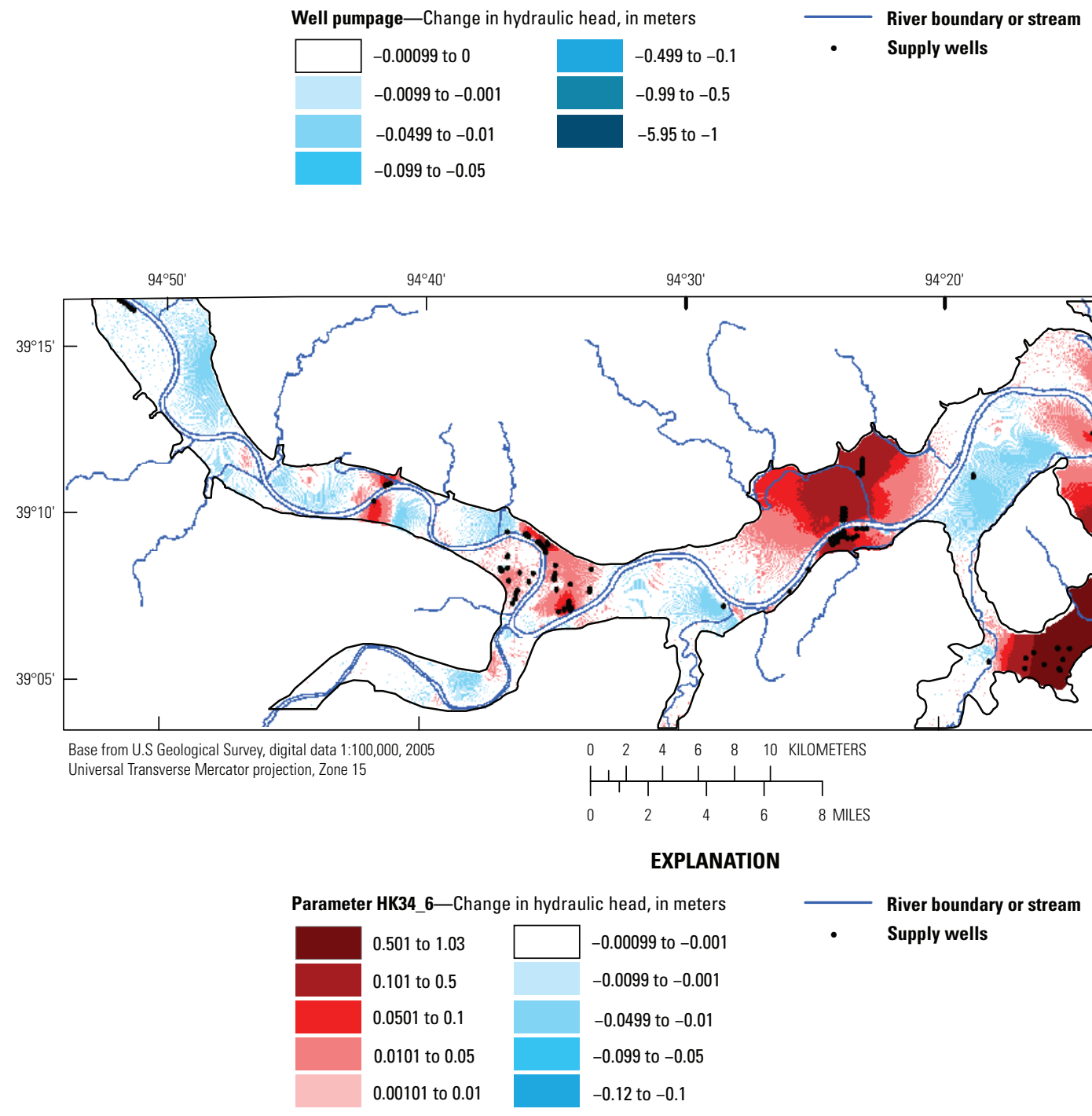

Figure 13. Change in simulated water levels for the 2007 base simulation resulting from doubling well pumpage, the parameters HK34_6, HK34_7, HK2_6, HK34_5, HK2_4, RPARM, and recharge. 


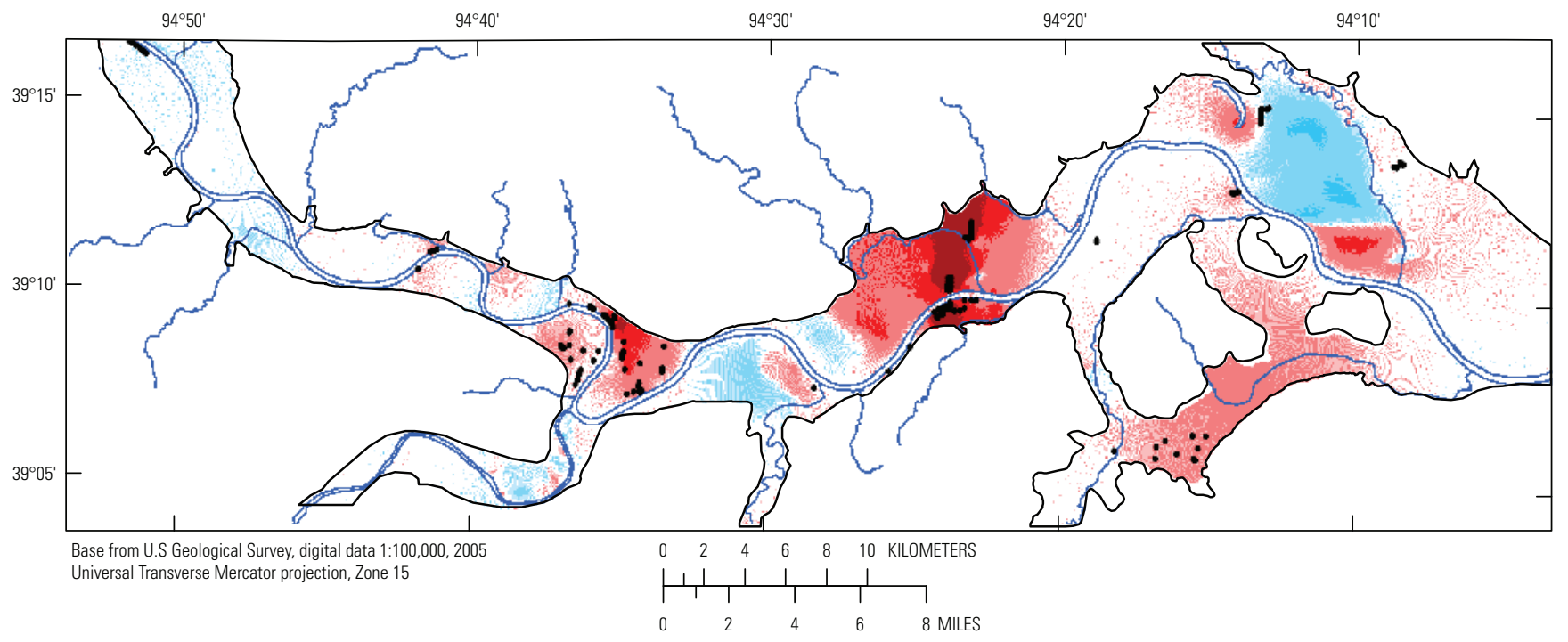

EXPLANATION

Parameter HK34_7—Change in hydraulic head, in meters

\begin{tabular}{|l|l|}
\hline 0.101 to 0.27 & -0.00099 to 0.001 \\
\hline 0.0501 to 0.1 & -0.0099 to -0.001 \\
\hline 0.0101 to 0.05 & -0.0499 to -0.01 \\
\hline 0.00101 to 0.01 & -0.099 to -0.05 \\
\hline & -0.12 to -0.1 \\
\hline
\end{tabular}
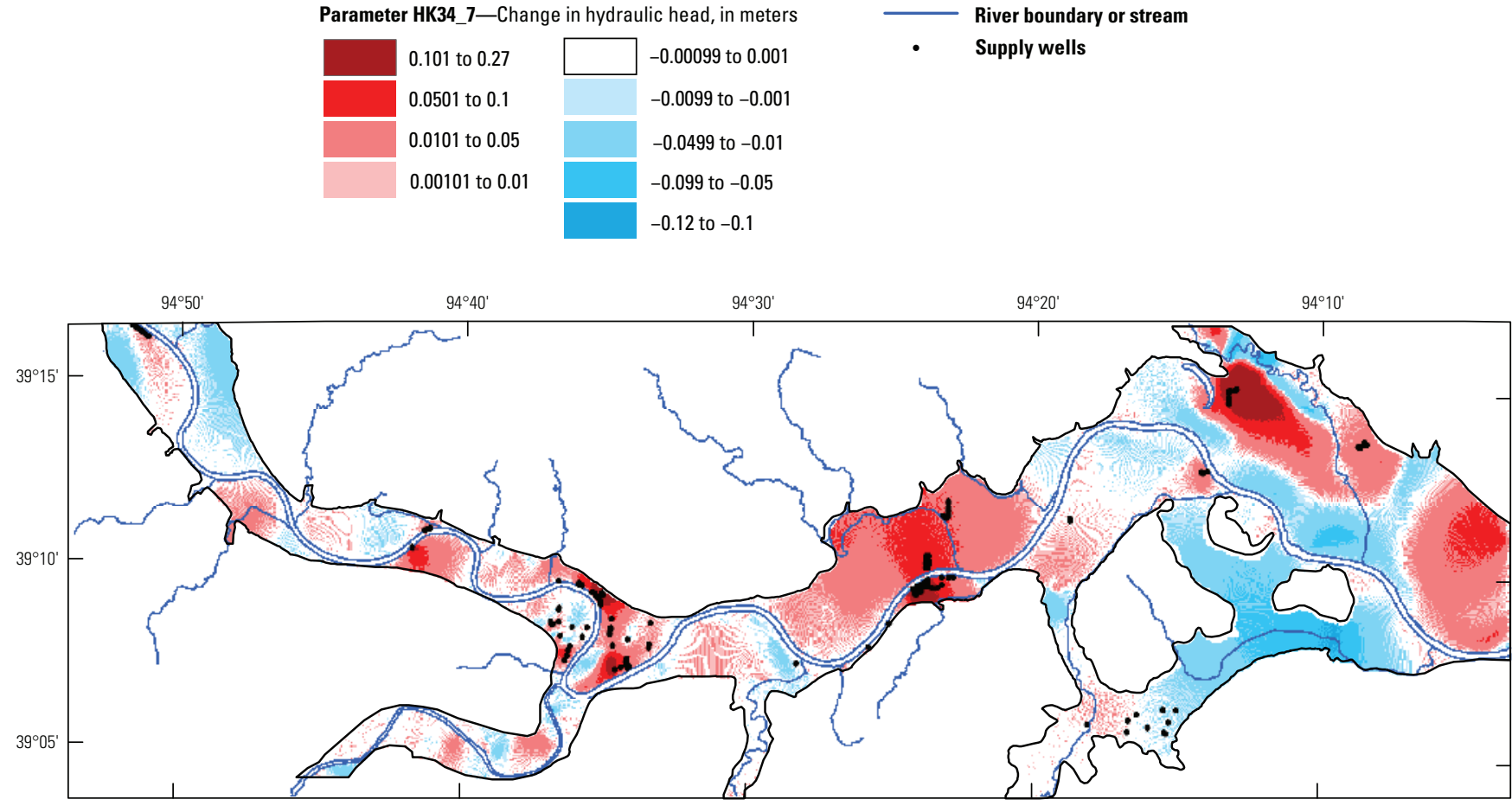

Base from U.S Geological Survey, digital data 1:100,000, 2005 Universal Transverse Mercator projection, Zone 15

\section{$\begin{array}{lllllll}0 & 2 & 4 & 6 & 8 & 10 & \text { KILOMETERS }\end{array}$

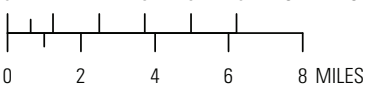 \\ EXPLANATION}

\begin{tabular}{|c|c|}
\hline 0.501 to 0.52 & -0.00099 to 0.001 \\
\hline 0.101 to 0.5 & -0.0099 to -0.001 \\
\hline 0.0501 to 0.1 & -0.0499 to -0.01 \\
\hline 0.0101 to 0.05 & -0.099 to -0.05 \\
\hline 0.00101 to 0.01 & -0.13 to -0.1 \\
\hline
\end{tabular}

Figure 13. Change in simulated water levels for the 2007 base simulation resulting from doubling well pumpage, the parameters HK34_6, HK34_7, HK2_6, HK34_5, HK2_4, RPARM, and recharge._Continued 


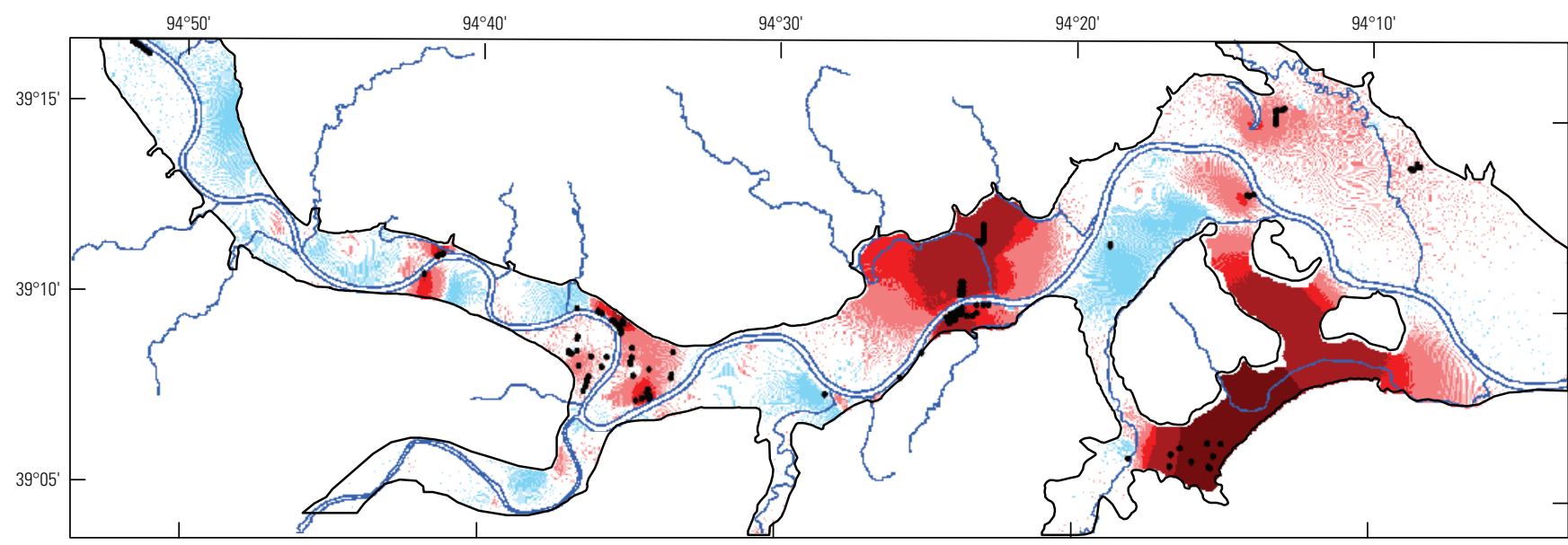

Base from U.S Geological Survey, digital data 1:100,000, 2005 Universal Transverse Mercator projection, Zone 15

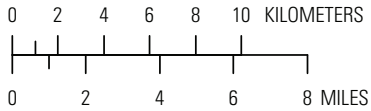

EXPLANATION
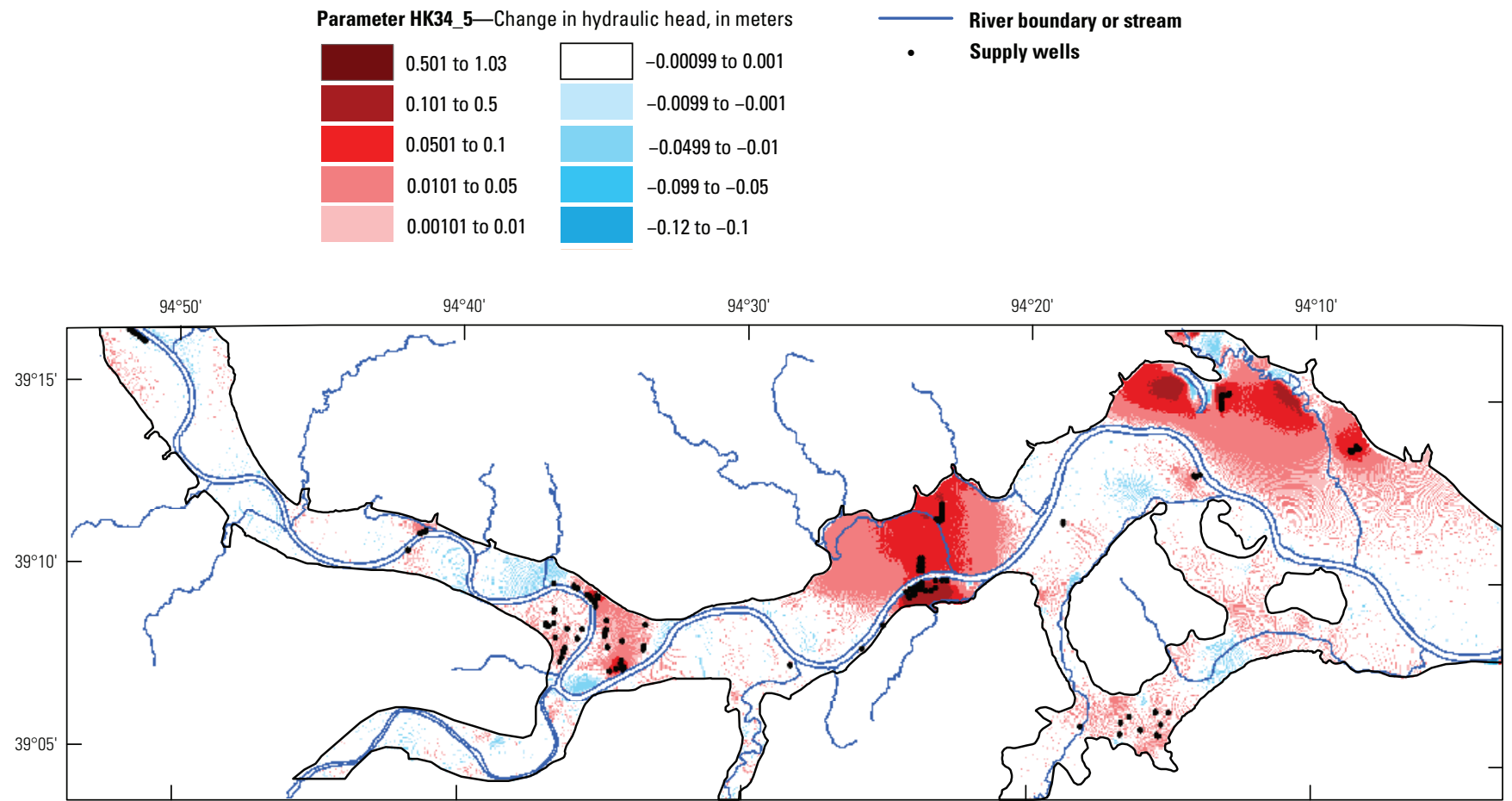

Base from U.S Geological Survey, digital data 1:100,000, 2005 Universal Transverse Mercator projection, Zone 15

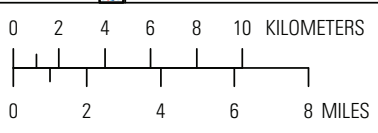

EXPLANATION

Parameter HK2_4-Change in hydraulic head, in meters

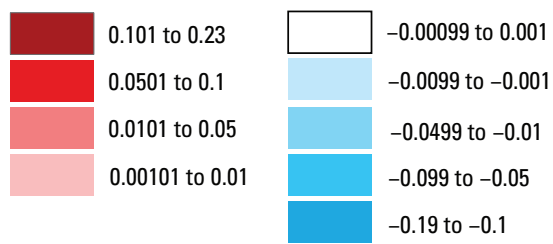

Figure 13. Change in simulated water levels for the 2007 base simulation resulting from doubling well pumpage, the parameters HK34_6, HK34_7, HK2_6, HK34_5, HK2_4, RPARM, and recharge.—Continued 


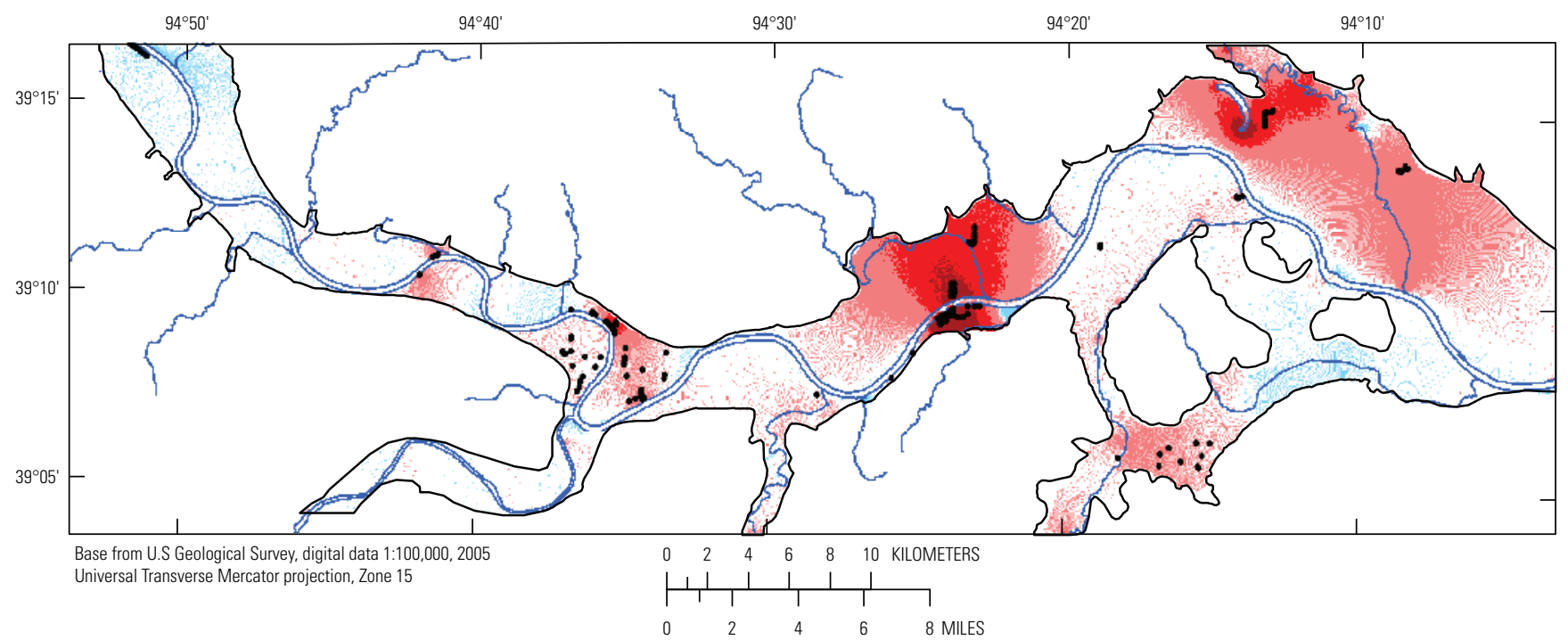

EXPLANATION
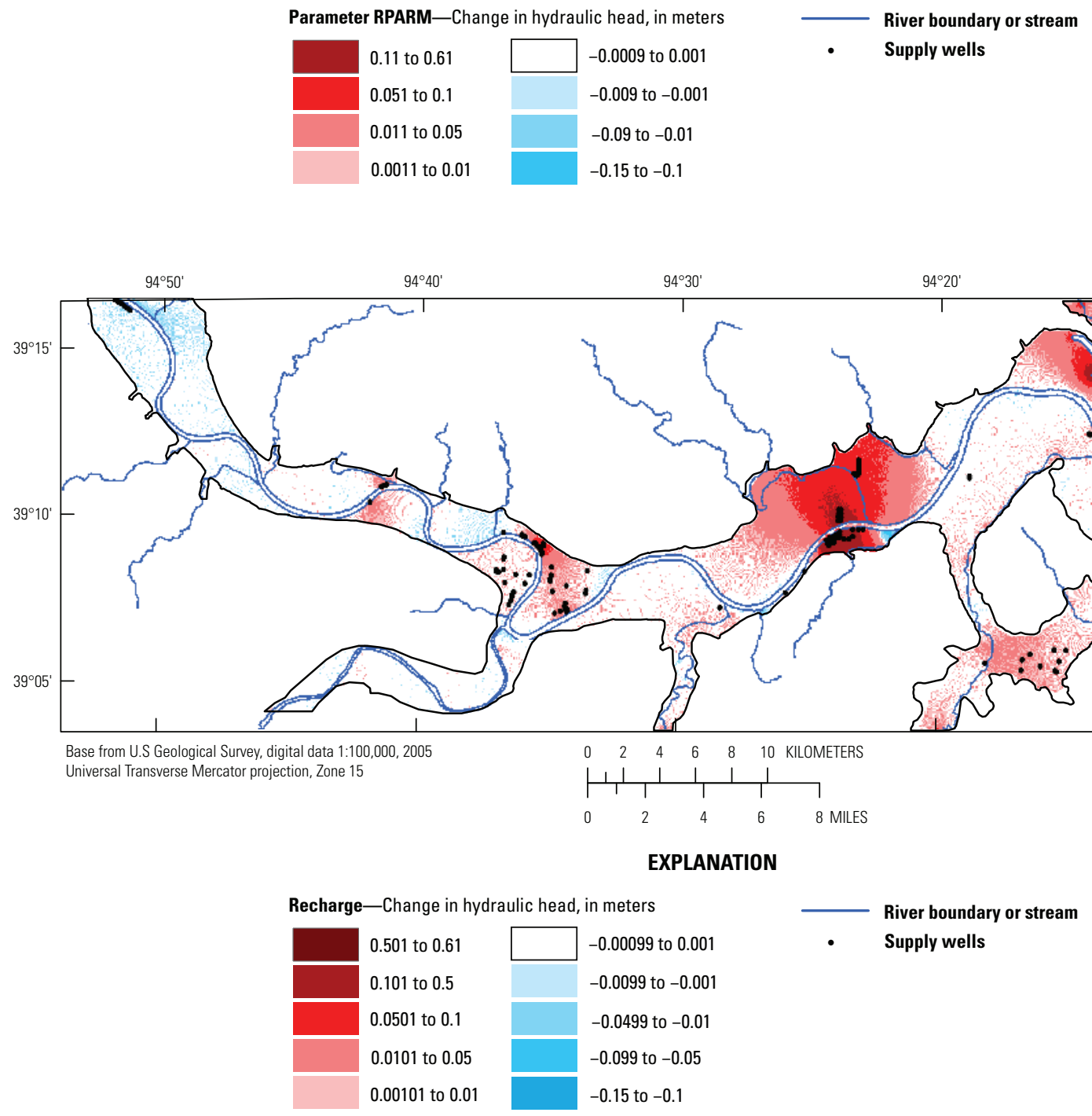

Figure 13. Change in simulated water levels for the 2007 base simulation resulting from doubling well pumpage, the parameters HK34_6, HK34_7, HK2_6, HK34_5, HK2_4, RPARM, and recharge.—Continued 
direction, CRAs to wells, and groundwater travel time in the Missouri River alluvial aquifer in the model area. To correctly interpret model results, the following limitations of the model are important to consider.

1. Model parameters such as hydraulic conductivity and recharge were applied uniformly within a cell. The assumption of homogeneity can cause inaccuracies because geologic materials and climatic conditions are typically heterogeneous.

2. The groundwater flow model was discretized using a grid with cells measuring $75 \mathrm{~m}$ by $75 \mathrm{~m}$. Model results were evaluated on a relatively large scale and cannot be used for detailed analyses such as simulating water-level drawdown near a single well. A grid with smaller cells would be needed for such detailed analysis.

3. Although the model was recalibrated to transient conditions, analyses of groundwater flow, CRAs, and travel time were based on simulated steady-state conditions. In alluvial aquifers similar to the Missouri River alluvial aquifer, steady-state conditions rarely, if ever, occur because of constantly changing river stage, rainfall, and well pumpage. Analyses based on steady-state conditions are considered approximations of current or historical conditions.

4. Well pumpage used in the groundwater flow model was either average annual pumpage or average monthly pumpage for supply wells or well fields. Average well pumpage may introduce some error in CRAs if most actual pumpage is from a small subset of wells in a well field but pumpage in the simulation was distributed evenly between all wells of the well field. Average well pumpage also may introduce error if water-level observations from monitoring wells located close to supply wells are obtained when the wells are pumping at a rate that is different than the average used in the model. In this case, matching the simulated water levels to observed water levels during calibration may either overestimate or underestimate hydraulic properties of the aquifer near the monitoring well.

5. The hydraulic head distribution of the quasi-steady-state simulation of average annual river stage, average annual rainfall, and average annual well pumping approximates the average distribution of hydraulic head. However, constantly changing river stage, rainfall, and well pumpage in the alluvial aquifer continuously add transient responses to the hydraulic head distribution that a simulated steady-state-hydraulic-head distribution do not include. When steady-state conditions do not exist, the use of a steady-state-hydraulic-head distribution as initial conditions for a transient simulation can introduce errors into the simulated transient hydraulic-head distribution because it does not include the responses to previous transient stresses. The use of a transient hydraulic-head distribution that developed in response to different transient stresses than those in effect can introduce similar errors. As the simulated hydraulichead distribution responds to each new stress during transient simulation, the effect of previous stresses on the current hydraulic-head distribution is reduced. Errors in transient calibration caused by using assumed quasisteady-state initial conditions in alluvial aquifers like the Missouri River alluvial aquifer are reduced when numerous stresses are simulated before comparing observed and simulated hydraulic heads.

\section{Contributing Recharge Areas and Groundwater Travel Time}

Particle-tracking analysis, using the USGS particletracking program MODPATH (Pollock, 1994), was used to determine the CRA and groundwater travel times between each CRA, monitoring wells, and supply well of the Independence well field. MODPATH uses the hydraulic heads and flow distribution output from MODFLOW to calculate the paths and travel times of imaginary particles of water moving through the simulated groundwater flow system. Limitations of particle-tracking analysis are discussed in detail by Pollock (1994), but several important factors that affect particle-tracking results follow. Groundwater particle movement and groundwater travel times computed by MODPATH are based solely on groundwater flow (advection). Because hydraulic conductivities are large in the Missouri River alluvial aquifer, groundwater flow probably is the largest component of contaminant movement rather than diffusion or dispersion. Whereas the rate of movement of a particular contaminant is not fully described by MODPATH results alone, a conservative estimate is computed that can be used for planning purposes. The spatial and temporal discretization of the groundwater flow model also can limit the accuracy of particle-tracking results because cells containing sinks that do not discharge at a rate large enough to consume all the water entering the cell introduce uncertainty into the computed path of the imaginary water particle. However, the most important factor affecting the accuracy of particle-tracking analysis is the accuracy of the hydraulic head and flow distribution computed by the groundwater flow model. Therefore, all of the limitations associated with the groundwater flow model also apply to the particle-tracking analysis.

The porosity of the alluvial aquifer has a large effect on groundwater velocities computed by MODPATH. The same groundwater discharge through a unit cross-sectional area of porous material with a high porosity will have a lower average groundwater flow velocity than a material with a low porosity. This occurs because the higher porosity material has more openings per unit area of porous material than does a lower porosity material, thereby allowing the same amount of discharge at a lower average groundwater velocity than in a lower porosity material. Three values of porosity $(0.2,0.22$, 
and 0.25) (Freeze and Cherry, 1979; Driscoll, 1986) were distributed among model cells by assigning porosity values to hydraulic conductivity zones listed in table 6 . In general, porosity values assigned to hydraulic conductivity zones in the updated simulation are less than those assigned to model cells in the original simulation. In the original simulation porosities were assigned based on lithology and distributed in the model by interpolation between data points. In the updated simulation, hydraulic conductivity zones, each of which represents a range of lithologies, were each assigned a single value for porosity. Because the predominant lithology in the Missouri River alluvial aquifer is sand or gravel, a porosity associated with those lithologies was chosen for use. The estimated distribution of porosity for each model layer is shown in figure 14 .

Steady-state groundwater flow was simulated to determine the hydraulic head distribution in the model area for 2007 well pumpage, average annual river stage, and average annual recharge. The hydraulic properties used in the steadystate simulation were determined from the transient calibration. In alluvial aquifer systems similar to the Missouri River alluvial aquifer, steady-state conditions rarely occur. Hydraulic properties are more accurately determined using transient calibration because transient water-level and river-stage observation data are available for calibration, but data for steadystate conditions are not. However, steady-state simulation of groundwater flow using 2007 well pumpage, average annual river stage, and average annual recharge is appropriate for analyzing long-term groundwater flow and travel time because 2007 pumping data include the new supply wells in the Independence well field, and average river stage and recharge approximate the other long-term stresses on the aquifer. Particle-tracking analysis was used to determine the CRA for supply wells and monitoring wells, the travel time from CRAs to supply wells, recharge areas to monitoring wells, and from monitoring wells to supply wells. Average annual well pumpage used for the steady-state simulation is listed for each Independence supply well by well identification, layer, row, and column and for other supply wells by layer, row, and column in table 7 at the back of this report. The river-surface altitude was defined for each cell in the model that contained a river. Average river stage data were chosen based on the river stage at the USGS streamgage located at Kansas City (U.S. Geological Survey, 2007). Average river stage conditions were represented when the stage at the streamgage was $219.16 \mathrm{~m}$ $\left(1,631.05 \mathrm{~m}^{3} / \mathrm{s}\right.$ discharge $)$. Average annual rainfall of $0.91 \mathrm{~m}$ (National Oceanic and Atmospheric Administration, 2008) was multiplied by the distribution of recharge as a percentage of rainfall shown in figure 12 to calculate recharge for steadystate groundwater flow. The steady-state 2007 base simulation groundwater flow budget is shown in table 8 .

Endpoint analysis was used to calculate the CRAs by placing one particle on the water table in the center of each of the top-most active model cells and tracking each particle to its eventual discharge location. Particles were placed in this manner for two reasons: most water entering the alluvial aquifer comes from direct infiltration by precipitation or from
Table 8. Steady-state 2007 base simulation groundwater flow budget.

\begin{tabular}{lcc}
\hline \multirow{2}{*}{\multicolumn{1}{c}{ Budget component }} & \multicolumn{2}{c}{$\begin{array}{c}\text { Cumulative volumes } \\
\text { (cubic meters per day) }\end{array}$} \\
\cline { 2 - 3 } & In & Out \\
\hline Wells & 0 & $483,883.75$ \\
Drains & 0 & $1,109.31$ \\
River leakage & $811,415.32$ & $980,606.56$ \\
Head dependent boundaries & $778,796.32$ & $141,141.39$ \\
Recharge & $16,417.29$ & 0 \\
Total & $1,606,628.88$ & $1,606,741.00$ \\
In-Out & \multicolumn{2}{c}{-112.12} \\
Percent discrepancy & \multicolumn{2}{c}{-0.01} \\
\hline
\end{tabular}

the major rivers, and the primary source of potential contamination to the alluvial aquifer is from leaks or spills that occur on the land surface. Consequently, the CRAs computed by MODPATH include the source area of water to each well or well field and advective groundwater travel times from the land surface and the major rivers to each well or well field. The starting locations and travel times of the particles that eventually discharged to each well or well field were identified. These location and times estimated the entire CRA for the well field and groundwater travel times from the particle locations within the CRA to the supply well. Flow-path analysis also was used as an alternative method to determine the CRA and groundwater flow to each supply well. Seven hundred and twenty-nine particles in a 9x9x9, three-dimensional array, were evenly spaced within each cell that contained a supply well. The particles were tracked backwards from each supply well to the location of recharge. The particle paths and groundwater travel times for each supply well were recorded. Each particle associated with a well travels away from the well along a different path and each particle has a unique travel time based on the length of time it traveled. Groundwater travel times for a particular supply well calculated using endpoint and flow-path analysis will have a range of values because more than one particle is associated with each well. The percentage of particles that end at the Missouri River or land surface indicate the relative contribution each of these make to the total flow to each supply well.

The shape and size of the CRA and groundwater travel time within the CRA for each supply well or the well field are affected by changes in river stage and well pumpage and by the location of the supply well or well field with respect to the major rivers, alluvial valley walls, and other supply wells. Similarities in the shapes of CRAs between different supply wells can be attributed to similarities in the pumping rate and the position of the wells or well fields in relation to the major rivers, the alluvial valley walls, or other well fields. An ideal CRA shape will be circular for a well within an aquifer with uniform hydraulic conductivity so that effects from any hydrologic boundary are negligible. 

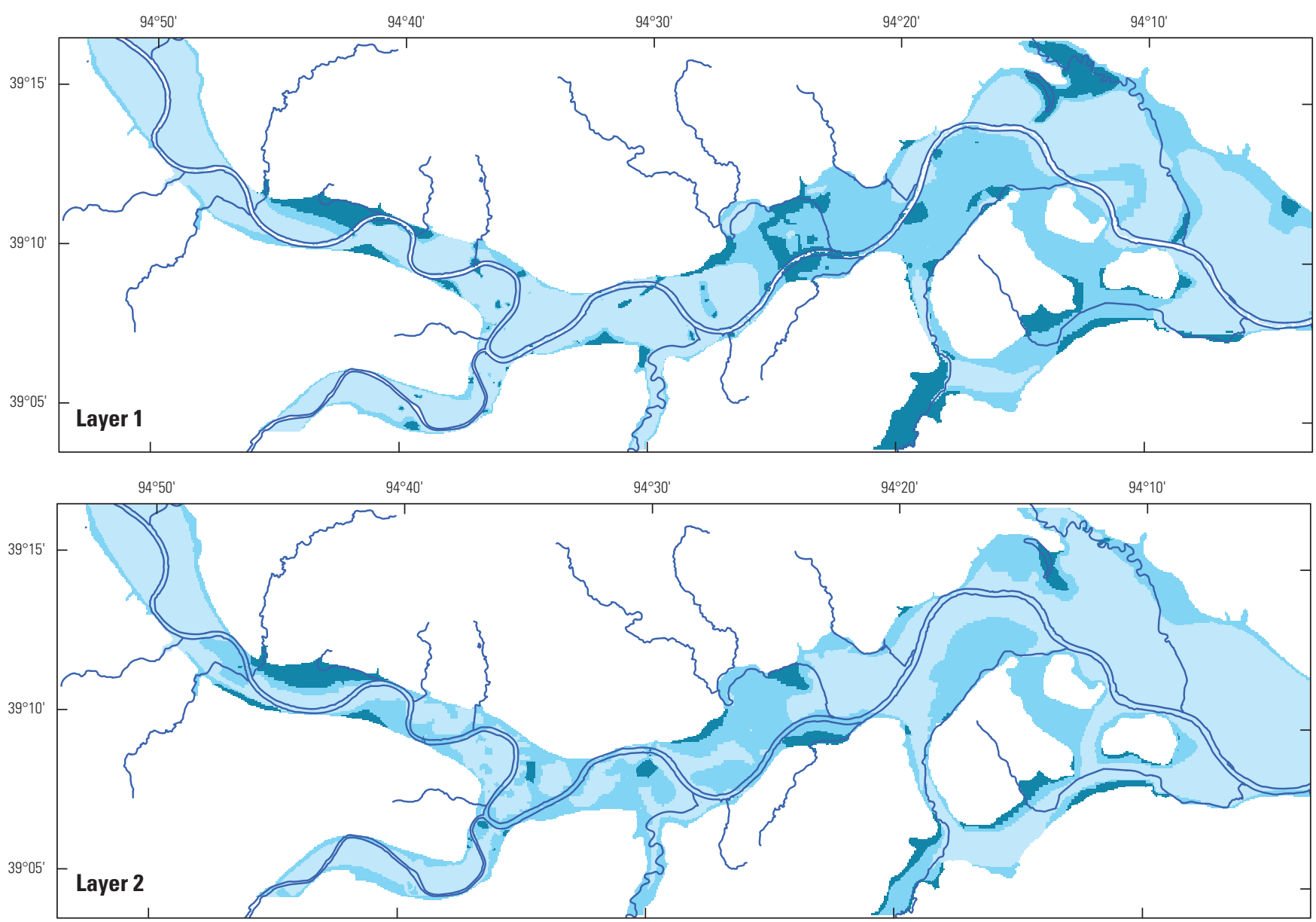

Base from U.S Geological Survey, digital data 1:100,000, 2005 Universal Transverse Mercator projection, Zone 15

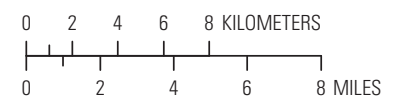

EXPLANATION

Porosity

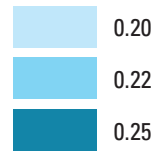

River boundary or stream

Figure 14. Estimated porosity distribution by model layer. 

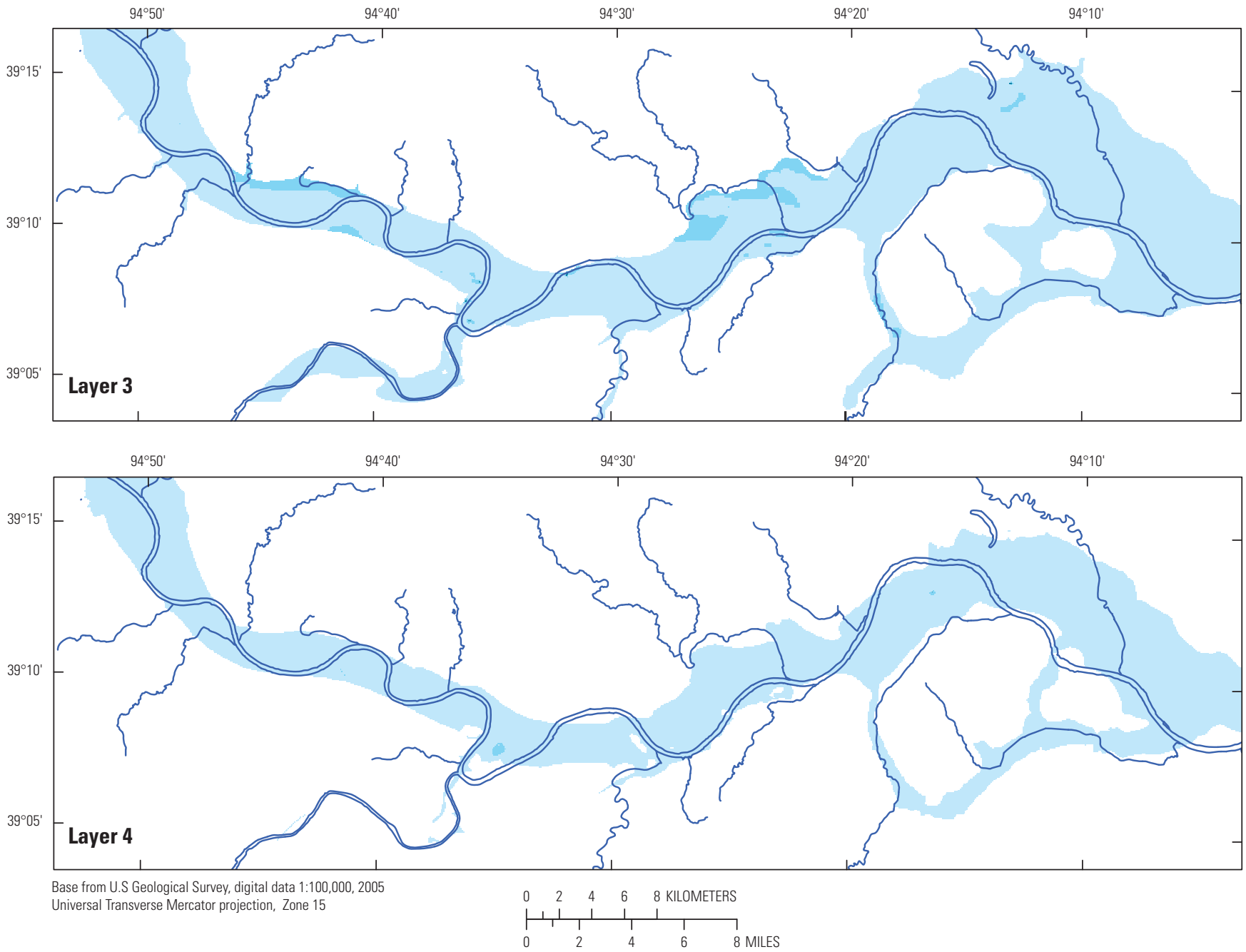

$4^{\circ} 20^{\prime}$

$94^{\circ} 10^{\prime}$

\section{EXPLANATION}

Porosity

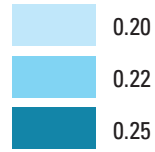

River boundary or stream

Figure 14. Estimated porosity distribution by model layer.-Continued 


\section{Groundwater Quality}

Water-quality samples were collected during ongoing annual sampling of the Independence groundwater monitoring well network (fig. 2). Methods of sample collection and analysis are described in Kelly (2002a). Water-quality constituent groups include dissolved oxygen and physical properties, nutrients (inorganic nitrogen species and orthophosphate), major ions and trace elements, wastewater indicator compounds, fuel compounds, and total benzene, toluene, ethylbenzene, and xylene (BTEX), alachlor, and atrazine. The constituents analyzed are listed in table 9.

Statistical summaries and the spatial and temporal variability of water quality in the Missouri River alluvial aquifer near the Independence well field include analyses of 598 water samples collected from 68 wells of the Independence groundwater monitoring well network (fig. 2) from 1997 to 2008. The total number of samples for each monitoring well and the number of analyses for each water-quality constituent group are listed in table 10. Combined wellfield sample, designated as IND in this report, was sampled from a tank where water from all supply wells is mixed before chlorination.

Results of analyses for all water-quality samples are available from the USGS National Water Information System at the URL http://nwis.waterdata.usgs.gov/mo/nwis/qwdata. Data can be retrieved for each monitoring well using the USGS site number listed in table 10. Statistical summaries of data from samples from monitoring wells with five or more samples are presented graphically as boxplots that include maximum, 75th percentile, median, 25th percentile, and minimum values (fig. 15). Data from samples from monitoring wells with three or four samples are presented graphically using maximum, median, and minimum values. Data from samples from monitoring wells with two samples are presented graphically using the maximum, average, and minimum values, and data from samples from monitoring wells with one sample are presented using the value. Waterquality results for constituents not detected (non detects) are reported as less than the laboratory reporting level (LRL) or method reporting level (MRL) and were set equal to the LRL or MRL. Assignment of the LRL or MRL to water-quality results less than the LRL or MRL can lead to incorrect or erroneous results if statistical analysis is performed on the data (Helsel, 2005). The summary statistics presented in this report are modified based on the percentage of non-detects assigned the LRL or MRL. For summary statistics where greater than 25 percent but less than 50 percent of the data were not detected, the maximum, median, and the LRL or MRL are shown for data with three or more samples; the maximum, average, and the LRL or MRL are shown for data with two samples, and the value is shown for data with one sample. For summary statistics where greater than 50 percent of the data were not detected, the maximum and the LRL or
MRL are shown. The slope of the line of best fit calculated using linear regression of median values was used to determine vertical trends for water samples grouped by depth interval and temporal trends for water samples grouped by year. Results of linear trend analysis of median values were not affected by assignment of LRLs or MRLs to non-detects because the analysis was performed only on data with more than 50 percent of sample results greater than the LRL or MRL.

Monitoring wells were grouped according to the depth of the screened interval into four categories: < (less than) $12 \mathrm{~m}, 12$ - to $18-\mathrm{m}, 18$ - to $24-\mathrm{m}$, and > (greater than) $24 \mathrm{~m}$. Maximum, median, and minimum concentrations were graphed for all samples from monitoring wells grouped by depth interval to show the vertical variability of selected water-quality constituents. Median values of selected waterquality constituents from water samples of the Independence monitoring well network were mapped for each depth interval to determine their areal distribution at each depth interval. The temporal variability of selected water-quality constituents was determined using graphs of linear trends of median concentrations for all samples from the well field grouped by year. The slope of the line of best fit calculated using linear regression of the median values indicates the rate of change of the median concentrations (Helsel and Hirsch, 2002). The correlation coefficient $\left(\mathrm{R}^{2}\right)$ indicates the amount of variability of the concentration to either depth or time. A larger $\mathrm{R}^{2}$ value indicates the median concentrations of a constituent have a larger relation of its variability to either depth or time than a smaller $\mathrm{R}^{2}$ value.

Quality assurance-quality control methodology used for this study and results of analyses of blanks, paired replicates, and samples collected from 1998 to 2000 are described in Kelly (2002a). Concentrations of nutrients, selected major ions and trace elements, wastewater indicator compounds, fuel compounds in blanks, and paired replicates, and samples collected from 2001 to 2008 are shown in table 11. Linear regression was used to compare samples and qualityassurance replicate samples collected between 1998 and 2008 for ammonia, calcium, chloride and arsenic (fig. 16). These constituents were selected because they are representative of quality-assurance sample results for other similar constituents. Correlation coefficients of 0.94 or greater indicate sampling and laboratory procedures did not bias sample results. Most concentrations were below detection for samples and replicate samples for wastewater indicator compounds and fuel compounds. However, $N, N$-diethylmeta-toluamide (DEET) and phenol were detected in blanks and both sample and replicate samples. DEET may have been introduced during sampling procedures because it is commonly used by USGS personnel when in the field. 
Table 9. Selected water-quality constituents analyzed in samples collected from the Independence monitoring wells.

[CAS, Chemical Abstract Service; LRL, 2008 laboratory reporting level; MRL, 2008 method reporting level; MCL, maximum contaminant level; DNR, Missouri Department of Natural Resources; SMCL, secondary maximum contaminant level; -, not applicable; $\mu \mathrm{S} / \mathrm{cm}$, microsiemens per centimeter at 25 degrees Celsius; ${ }^{\circ} \mathrm{C}$, degrees Celsius; mg/L, milligrams per liter; $\mu \mathrm{g} / \mathrm{L}$, micrograms per liter; $\mathrm{CaCO}_{3}$, calcium carbonate; $\mathrm{HCO}_{3}$, bicarbonate; BTEX, benzene, toluene, ethylbenzene, and xylene]

\begin{tabular}{|c|c|c|c|c|c|c|}
\hline Property or constituent & ${ }^{\mathrm{a} C A S}$ Number & LRL & MRL & ${ }^{\mathrm{b}} \mathrm{MCL}$ DNR & 'DSMCL DNR & Units \\
\hline \multicolumn{7}{|c|}{ Dissolved oxygen and physical properties } \\
\hline $\mathrm{pH}$ & - & - & .1 & - & - & $\mathrm{pH}$ \\
\hline Temperature & - & - & .1 & - & - & ${ }^{\circ} \mathrm{C}$ \\
\hline \multicolumn{7}{|c|}{ Nutrients } \\
\hline Nitrogen, ammonia & 7664-41-7 & .04 & - & - & - & $\mathrm{mg} / \mathrm{L}$ \\
\hline Nitrogen, nitrite + nitrate & - & .06 & - & 10 & - & $\mathrm{mg} / \mathrm{L}$ \\
\hline \multicolumn{7}{|c|}{ Major ions and iron } \\
\hline Calcium & $7440-70-2$ & .010 & - & - & - & $\mathrm{mg} / \mathrm{L}$ \\
\hline Magnesium & $7439-95-4$ & .008 & - & - & - & $\mathrm{mg} / \mathrm{L}$ \\
\hline Potassium & 7440.09-7 & - & .06 & - & - & $\mathrm{mg} / \mathrm{L}$ \\
\hline Silica & $7631-86-9$ & .04 & - & - & - & $\mathrm{mg} / \mathrm{L}$ \\
\hline Sodium & $7440-23-5$ & .10 & - & - & - & $\mathrm{mg} / \mathrm{L}$ \\
\hline Aluminum & $7429-90-5$ & 1.6 & - & - & 50 & $\mu \mathrm{g} / \mathrm{L}$ \\
\hline Antimony & $7440-36-0$ & .06 & - & 6 & - & $\mu \mathrm{g} / \mathrm{L}$ \\
\hline Arsenic & $7440-38-2$ & .2 & - & 10 & - & $\mu \mathrm{g} / \mathrm{L}$ \\
\hline Barium & $7440-39-3$ & .2 & - & 2,000 & - & $\mu \mathrm{g} / \mathrm{L}$ \\
\hline Beryllium & $7440-41-7$ & .06 & - & 4 & - & $\mu \mathrm{g} / \mathrm{L}$ \\
\hline Boron & $7440-42-8$ & 8 & - & - & - & $\mu \mathrm{g} / \mathrm{L}$ \\
\hline Cadmium & $7440-43-9$ & .04 & - & 5 & - & $\mu \mathrm{g} / \mathrm{L}$ \\
\hline Chromium & $7440-47-3$ & .8 & - & 100 & - & $\mu \mathrm{g} / \mathrm{L}$ \\
\hline Cobalt & $7440-48-4$ & .0 & - & - & - & $\mu \mathrm{g} / \mathrm{L}$ \\
\hline Copper & $7440-50-8$ & .4 & - & - & 1,000 & $\mu \mathrm{g} / \mathrm{L}$ \\
\hline Iron & $7439-89-6$ & 6.4 & - & - & 300 & $\mu \mathrm{g} / \mathrm{L}$ \\
\hline Lead & $7439-92-1$ & .1 & - & 15 & - & $\mu \mathrm{g} / \mathrm{L}$ \\
\hline Lithium & $7439-93-2$ & .6 & - & - & - & $\mu \mathrm{g} / \mathrm{L}$ \\
\hline Vanadium & $7440-62-2$ & .14 & - & - & - & $\mu \mathrm{g} / \mathrm{L}$ \\
\hline Zinc & $7440-66-6$ & .6 & - & - & 5,000 & $\mu \mathrm{g} / \mathrm{L}$ \\
\hline \multicolumn{7}{|c|}{ Wastewater indicator compounds } \\
\hline Cotinine & $486-56-6$ & - & 1 & - & - & $\mu \mathrm{g} / \mathrm{L}$ \\
\hline 5-Methyl-1H-benzotriazole & $136-85-6$ & - & 2 & - & - & $\mu \mathrm{g} / \mathrm{L}$ \\
\hline Anthraquinone & $84-65-1$ & - & .5 & - & - & $\mu \mathrm{g} / \mathrm{L}$ \\
\hline Acetophenone & $98-86-2$ & - & .5 & - & - & $\mu \mathrm{g} / \mathrm{L}$ \\
\hline Acetyl hexamethyl tetrahydronaphthalene (AHTN) & $21145-77-7$ & - & .5 & - & - & $\mu \mathrm{g} / \mathrm{L}$ \\
\hline Anthracene & $120-12-7$ & - & .5 & - & - & $\mu \mathrm{g} / \mathrm{L}$ \\
\hline 1,4-Dichlorobenzene & $106-46-7$ & - & .5 & - & 75 & $\mu \mathrm{g} / \mathrm{L}$ \\
\hline Benzo[a]pyrene & $50-32-8$ & - & .5 & - & .2 & $\mu \mathrm{g} / \mathrm{L}$ \\
\hline Benzophenone & $119-61-9$ & - & .5 & - & -.2 & $\mu \mathrm{g} / \mathrm{L}$ \\
\hline Bromacil & $314-40-9$ & - & .5 & - & - & $\mu \mathrm{g} / \mathrm{L}$ \\
\hline Bromoform & $75-25-2$ & - & .5 & - & - & $\mu \mathrm{g} / \mathrm{L}$ \\
\hline 3-tert-Butyl-4-hydroxy anisole (BHA) & $25013-16-5$ & - & 5 & - & - & $\mu \mathrm{g} / \mathrm{L}$ \\
\hline Caffeine & $58-08-2$ & - & .2 & - & - & $\mu \mathrm{g} / \mathrm{L}$ \\
\hline Camphor & $76-22-2$ & - & .5 & - & - & $\mu \mathrm{g} / \mathrm{L}$ \\
\hline Carbaryl & $63-25-2$ & - & 1 & - & - & $\mu \mathrm{g} / \mathrm{L}$ \\
\hline Carbazole & $86-74-8$ & - & .5 & - & - & $\mu \mathrm{g} / \mathrm{L}$ \\
\hline
\end{tabular}


Table 9. Selected water-quality constituents analyzed in samples collected from the Independence monitoring wells.—Continued

[CAS, Chemical Abstract Service; LRL, 2008 laboratory reporting level; MRL, 2008 method reporting level; MCL, maximum contaminant level; DNR, Missouri Department of Natural Resources; SMCL, secondary maximum contaminant level; -, not applicable; $\mu \mathrm{S} / \mathrm{cm}$, microsiemens per centimeter at 25 degrees Celsius; ${ }^{\circ} \mathrm{C}$, degrees Celsius; $\mathrm{mg} / \mathrm{L}$, milligrams per liter; $\mu \mathrm{g} / \mathrm{L}$, micrograms per liter; $\mathrm{CaCO}_{3}$, calcium carbonate; $\mathrm{HCO}_{3}$, bicarbonate; BTEX, benzene, toluene, ethylbenzene, and xylene]

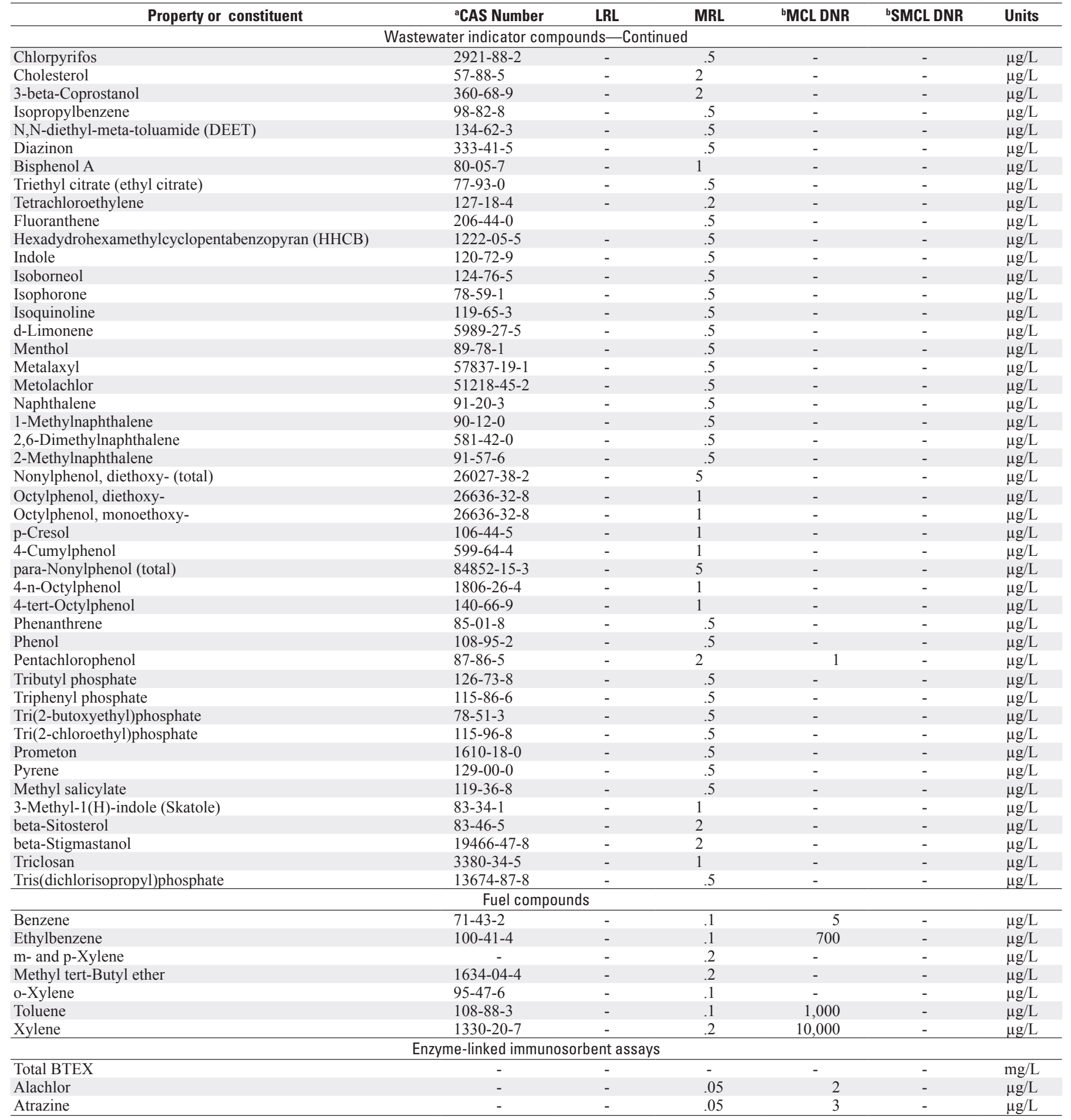

a"This report contains CAS Registry Number, which is a registered trademark of the American Chemical Society. CAS recommends the verification of the CASRNs through CAS Client Services ${ }^{\mathrm{sm}}$."

${ }^{\mathrm{b}}$ Missouri Department of Natural Resources, 2003. 
Table 10. Total number of samples for each monitoring well and number of analyses for each water-quality constituent group.

[USGS, U.S. Geological Survey; Fuel, fuel compounds; ELISA, enzyme-linked immunosorbent assay; BTEX, benzene, toluene, ethylbenzene, xylene; IND, combined well field sample]

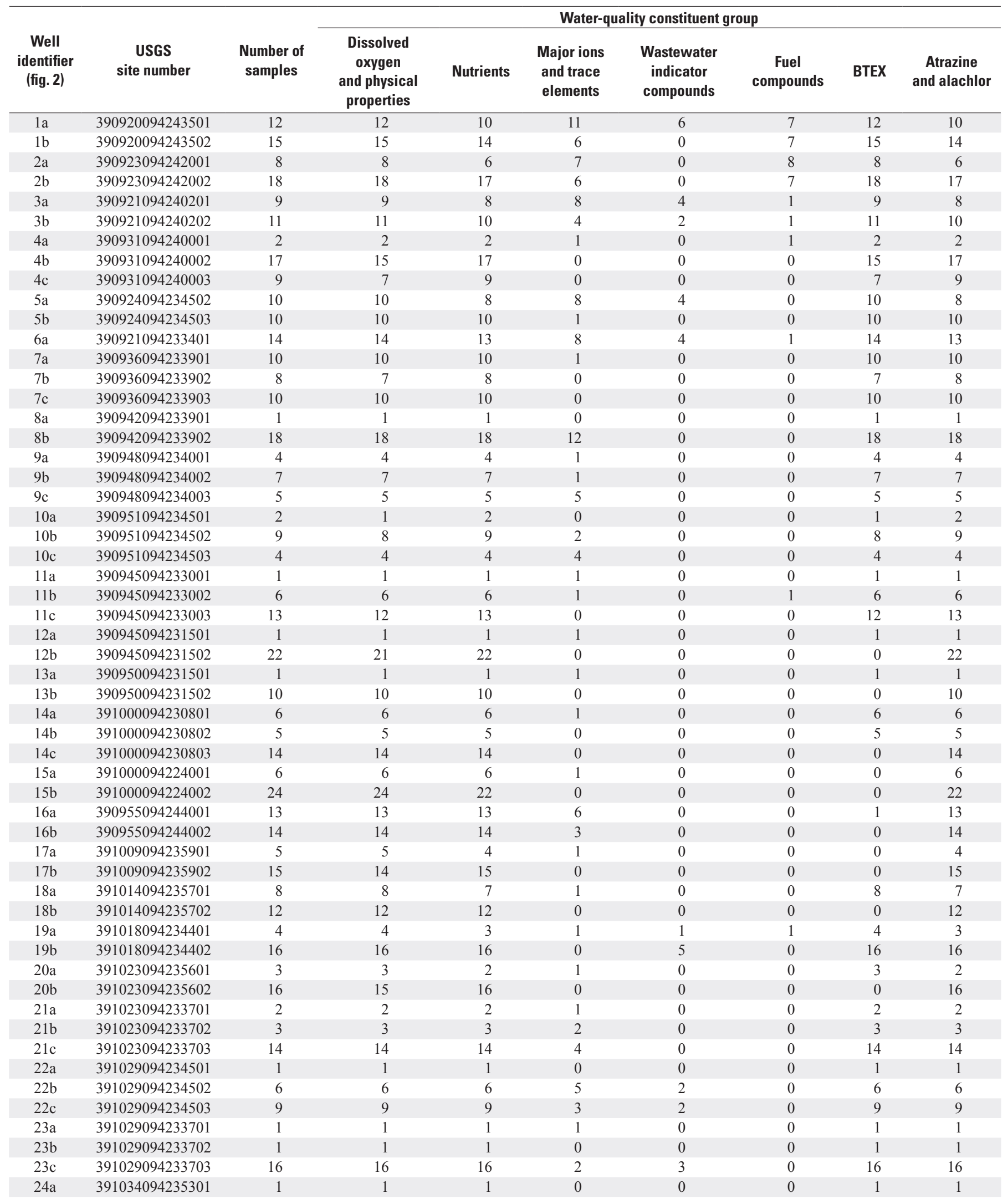


Table 10. Total number of samples for each monitoring well and number of analyses for each water-quality constituent group.-Continued

[USGS, U.S. Geological Survey; Fuel, fuel compounds; ELISA, enzyme-linked immunosorbent assay; BTEX, benzene, toluene, ethylbenzene, xylene; IND, combined well field sample]

\begin{tabular}{|c|c|c|c|c|c|c|c|c|c|}
\hline \multirow[b]{2}{*}{$\begin{array}{c}\text { Well } \\
\text { identifier } \\
\text { (fig. 2) }\end{array}$} & \multirow[b]{2}{*}{$\begin{array}{c}\text { USGS } \\
\text { site number }\end{array}$} & \multirow[b]{2}{*}{$\begin{array}{c}\text { Number of } \\
\text { samples }\end{array}$} & \multicolumn{7}{|c|}{ Water-quality constituent group } \\
\hline & & & $\begin{array}{c}\text { Dissolved } \\
\text { oxygen } \\
\text { and physical } \\
\text { properties }\end{array}$ & Nutrients & $\begin{array}{l}\text { Major ions } \\
\text { and trace } \\
\text { elements }\end{array}$ & $\begin{array}{l}\text { Wastewater } \\
\text { indicator } \\
\text { compounds }\end{array}$ & $\begin{array}{c}\text { Fuel } \\
\text { compounds }\end{array}$ & BTEX & $\begin{array}{c}\text { Atrazine } \\
\text { and alachlor }\end{array}$ \\
\hline $24 b$ & 391034094235302 & 3 & 3 & 3 & 2 & 0 & 0 & 3 & 3 \\
\hline $24 c$ & 391034094235303 & 16 & 16 & 15 & 5 & 0 & 0 & 16 & 15 \\
\hline $25 \mathrm{a}$ & 391042094241701 & 3 & 3 & 1 & 0 & 0 & 0 & 0 & 1 \\
\hline $25 b$ & 391042094241702 & 8 & 8 & 8 & 0 & 0 & 0 & 0 & 8 \\
\hline $25 c$ & 391042094241703 & 10 & 10 & 10 & 4 & 0 & 0 & 10 & 10 \\
\hline $26 \mathrm{a}$ & 391032094243301 & 1 & 1 & 1 & 0 & 0 & 0 & 0 & 1 \\
\hline $26 b$ & 391032094243302 & 14 & 14 & 13 & 7 & 0 & 0 & 14 & 13 \\
\hline $27 \mathrm{a}$ & 391015094245802 & 8 & 8 & 7 & 0 & 0 & 0 & 8 & 7 \\
\hline $27 b$ & 391015094245803 & 10 & 10 & 10 & 4 & 0 & 0 & 10 & 10 \\
\hline $28 \mathrm{a}$ & 391029094240202 & 5 & 5 & 5 & 0 & 0 & 4 & 5 & 5 \\
\hline $28 b$ & 391029094240201 & 5 & 5 & 5 & 5 & 0 & 4 & 5 & 5 \\
\hline $29 a$ & 391021094242302 & 5 & 5 & 5 & 0 & 0 & 4 & 5 & 5 \\
\hline $29 b$ & 391021094242301 & 5 & 5 & 4 & 4 & 1 & 3 & 5 & 4 \\
\hline IND & 390939094240201 & 23 & 23 & 22 & 11 & 6 & 0 & 23 & 22 \\
\hline Total & & 598 & 587 & 574 & 165 & 40 & 50 & 428 & 574 \\
\hline
\end{tabular}

Box plots for wells with less than 25 percent of samples with non-detectable constituents
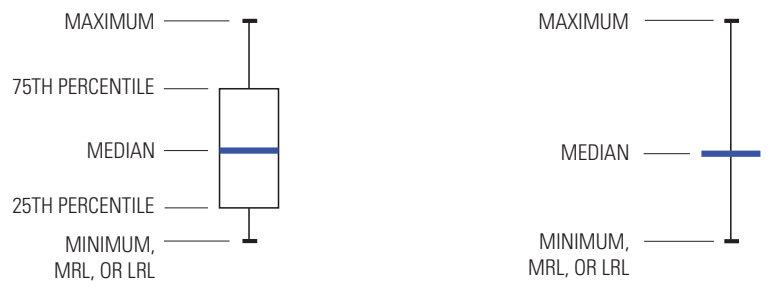

Data from wells with five or more samples

Data from wells with three or four samples

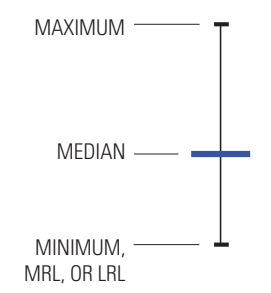

Data from wells with two samples

Data from wells with one sample

Box plots for wells with more than $\mathbf{2 5}$ percent and less than $\mathbf{5 0}$ percent of samples with non-detectable constituents

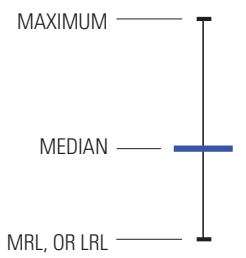

Data from wells with three or more samples

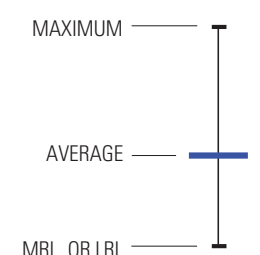

Data from wells with two samples
Data from wells with one sample

Box plots for wells with greater than 50 percent of samples with non-detectable constituents
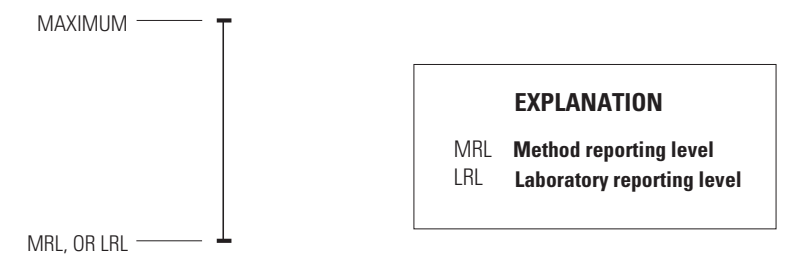

Figure 15. Features of boxplots used in this report. 
Table 11. Concentrations of selected constituents in blanks, replicates, and samples.

$[\mathrm{mg} / \mathrm{L}$, milligrams per liter; a, b, c in identifier indicates relative depth of the well in each nest from "a" the deepest to "c" the shallowest. For well nest 4, 4a is deepest, $4 \mathrm{c}$ is intermediate, and $4 \mathrm{~b}$ is shallowest; b, blank; <, less than; s, sample; r, replicate, E, estimated; $\mu \mathrm{g} / \mathrm{L}$, micrograms per liter; M, detected but not estimated]

\begin{tabular}{|c|c|c|c|c|c|c|}
\hline \multirow{2}{*}{$\begin{array}{c}\text { Well } \\
\text { identifier }\end{array}$} & \multirow[b]{2}{*}{ Date } & \multirow{2}{*}{$\begin{array}{c}\text { Sample } \\
\text { type }\end{array}$} & \multicolumn{4}{|c|}{ Nutrients } \\
\hline & & & \multicolumn{4}{|c|}{$\mathrm{mg} / \mathrm{L}$} \\
\hline 1a & $6 / 20 / 2005$ & $\mathrm{~b}$ & $<0.04$ & $<0.06$ & ${ }^{a}<0.008$ & $\mathrm{a}<0.02$ \\
\hline 1a & $6 / 20 / 2006$ & $\mathrm{r}$ & 3.11 & $<.06$ & $<.002$ & .013 \\
\hline 1a & $6 / 20 / 2006$ & $\mathrm{~s}$ & 3.08 & $<.06$ & $<.002$ & .015 \\
\hline $1 \mathrm{a}$ & $7 / 18 / 2007$ & $\mathrm{r}$ & 3.29 & $<.06$ & .002 & .065 \\
\hline $4 \mathrm{~b}$ & $6 / 20 / 2007$ & $\mathrm{~s}$ & $<.02$ & 3.78 & .014 & .025 \\
\hline $26 \mathrm{~b}$ & $6 / 8 / 2005$ & $\mathrm{r}$ & .64 & .06 & ${ }^{\mathrm{a}}<.008$ & .03 \\
\hline $26 \mathrm{~b}$ & $6 / 8 / 2005$ & $\mathrm{~s}$ & .64 & .06 & ${ }^{\mathrm{a}}<.008$ & .04 \\
\hline
\end{tabular}

\begin{tabular}{|c|c|c|c|c|c|c|c|c|c|c|}
\hline \multirow{2}{*}{$\begin{array}{c}\text { Well } \\
\text { identifier }\end{array}$} & \multirow[b]{2}{*}{ Date } & \multirow{2}{*}{$\begin{array}{c}\text { Sample } \\
\text { type }\end{array}$} & \multicolumn{8}{|c|}{ Major ions } \\
\hline & & & \multicolumn{7}{|c|}{$\mathrm{mg} / \mathrm{L}$} & $\begin{array}{l}\text { ug/L } \\
\text { Iron }\end{array}$ \\
\hline 1a & $6 / 20 / 2005$ & $\mathrm{~b}$ & 0.06 & $<0.008$ & 0.17 & $<0.2$ & $<0.1$ & 0.79 & $<0.18$ & $<6$ \\
\hline $1 \mathrm{a}$ & $6 / 20 / 2006$ & $\mathrm{r}$ & 232 & 64.4 & 54.6 & 23.2 & .29 & 37.8 & 298 & 25,600 \\
\hline $1 \mathrm{a}$ & $6 / 20 / 2006$ & $\mathrm{~s}$ & 237 & 66 & 55.9 & 23.2 & .29 & 39.2 & 298 & 26,600 \\
\hline $1 \mathrm{a}$ & $7 / 18 / 2007$ & $\mathrm{r}$ & 233 & 63.2 & 65 & 26.5 & .32 & 41.7 & 351 & 28,700 \\
\hline $1 \mathrm{a}$ & $7 / 11 / 2008$ & $\mathrm{~s}$ & 215 & 58.6 & 52.8 & 23.7 & .29 & 36.7 & 261 & 26,600 \\
\hline $22 b$ & $6 / 7 / 2005$ & $\mathrm{r}$ & 265 & 46.3 & 16.9 & 46.9 & .26 & 41.9 & 164 & 18,500 \\
\hline $22 b$ & $6 / 7 / 2005$ & $\mathrm{~s}$ & 255 & 44.9 & 17.7 & 47.7 & .28 & 36.8 & 164 & 18,500 \\
\hline $26 \mathrm{~b}$ & $6 / 8 / 2005$ & $\mathrm{r}$ & 162 & 43.5 & 27.2 & 6.49 & .31 & 36.3 & $<.18$ & 13,100 \\
\hline $26 \mathrm{~b}$ & $6 / 8 / 2005$ & $\mathrm{~s}$ & 169 & 43.9 & 28.1 & 6.45 & .29 & 36.4 & .18 & 13,400 \\
\hline
\end{tabular}

\begin{tabular}{|c|c|c|c|c|c|c|}
\hline \multirow{2}{*}{$\begin{array}{c}\text { Well } \\
\text { identifier }\end{array}$} & \multirow[b]{2}{*}{ Date } & \multirow{2}{*}{$\begin{array}{c}\text { Sample } \\
\text { type }\end{array}$} & \multicolumn{4}{|c|}{ Trace elements } \\
\hline & & & \multicolumn{4}{|c|}{$\mu \mathrm{g} / \mathrm{L}$} \\
\hline 1a & $6 / 20 / 2005$ & $\mathrm{~b}$ & ${ }^{\mathrm{a}}<0.2$ & $<0.2$ & $<0.2$ & $<0.2$ \\
\hline $1 \mathrm{a}$ & $6 / 20 / 2006$ & $\mathrm{r}$ & ${ }^{\mathrm{a}}<.2$ & 5.1 & 229 & 1,300 \\
\hline 1a & $6 / 20 / 2006$ & $\mathrm{~s}$ & ${ }^{\mathrm{a}}<.2$ & 5.2 & 230 & 1,280 \\
\hline $1 \mathrm{a}$ & $7 / 11 / 2008$ & $\mathrm{r}$ & $<.14$ & 6.5 & 252 & 1,160 \\
\hline $1 \mathrm{a}$ & $7 / 11 / 2008$ & $\mathrm{~s}$ & $<.14$ & 6.5 & 247 & 1,140 \\
\hline $22 b$ & $6 / 7 / 2005$ & $\mathrm{r}$ & ${ }^{\mathrm{a}}<.2$ & 7.5 & 308 & 1,940 \\
\hline $22 b$ & $6 / 7 / 2005$ & $\mathrm{~s}$ & .45 & 7.1 & 426 & 1,930 \\
\hline $26 \mathrm{~b}$ & $6 / 8 / 2005$ & $r$ & ${ }^{\mathrm{a}}<.2$ & .3 & 1,630 & 258 \\
\hline $26 \mathrm{~b}$ & $6 / 8 / 2005$ & $\mathrm{~s}$ & ${ }^{a}<.2$ & .3 & 1,630 & 258 \\
\hline
\end{tabular}


Table 11. Concentrations of selected constituents in blanks, replicates, and samples._- Continued

$[\mathrm{mg} / \mathrm{L}$, milligrams per liter; a,b,c in identifier indicates relative depth of the well in each nest from "a" the deepest to "c" the shallowest. For well nest 4, 4a is deepest, $4 \mathrm{c}$ is intermediate, and $4 \mathrm{~b}$ is shallowest; $\mathrm{b}$, blank; <, less than; $\mathrm{s}$, sample; $\mathrm{r}$, replicate, E, estimated; $\mu \mathrm{g} / \mathrm{L}$, micrograms per liter; M, detected but not estimated]

\begin{tabular}{|c|c|c|c|c|c|c|}
\hline \multirow{2}{*}{$\begin{array}{c}\text { Well } \\
\text { identifier }\end{array}$} & \multirow{2}{*}{ Date } & \multirow{2}{*}{$\begin{array}{l}\text { Sample } \\
\text { type }\end{array}$} & \multicolumn{4}{|c|}{ Wastewater indicator compounds } \\
\hline & & & \multicolumn{4}{|c|}{$\mu \mathrm{g} / \mathrm{L}$} \\
\hline $1 \mathrm{a}$ & $6 / 20 / 2005$ & $\mathrm{~s}$ & M & $\mathrm{a}<.5$ & 1.4 & ${ }^{\mathrm{b}} \mathrm{E} .1$ \\
\hline $1 \mathrm{a}$ & $6 / 20 / 2006$ & $\mathrm{r}$ & $<.5$ & $\mathrm{a}<.5$ & $<.5$ & $\mathrm{a}<.5$ \\
\hline $1 \mathrm{a}$ & $6 / 20 / 2006$ & $\mathrm{~s}$ & $<.5$ & $\mathrm{a}<.5$ & $<.5$ & $\mathrm{a}<.5$ \\
\hline $1 \mathrm{a}$ & $7 / 18 / 2007$ & $\mathrm{r}$ & $\mathrm{M}$ & $<.2$ & ${ }^{\mathrm{b}} \mathrm{E} .3$ & $<.2$ \\
\hline $1 \mathrm{a}$ & $7 / 11 / 2008$ & $\mathrm{~s}$ & ${ }^{\mathrm{b}} \mathrm{E} .1$ & $<.2$ & $<.5$ & $<.2$ \\
\hline $22 b$ & $6 / 7 / 2005$ & $\mathrm{r}$ & M & $\mathrm{a}<.5$ & .5 & $\mathrm{a}<.5$ \\
\hline $22 b$ & $6 / 25 / 2007$ & $\mathrm{~s}$ & & $\mathrm{M}$ & .5 & ${ }^{\mathrm{a}}<.5$ \\
\hline
\end{tabular}

\begin{tabular}{|c|c|c|c|c|c|c|c|c|c|}
\hline \multirow{2}{*}{$\begin{array}{c}\text { Well } \\
\text { identifier }\end{array}$} & \multirow{2}{*}{ Date } & \multirow{2}{*}{$\begin{array}{c}\text { Sample } \\
\text { type }\end{array}$} & \multicolumn{7}{|c|}{ Fuel compounds } \\
\hline & & & \multicolumn{7}{|c|}{$\mu \mathrm{g} / \mathrm{L}$} \\
\hline 1a & $6 / 20 / 2005$ & $\mathrm{~b}$ & $<0.1$ & $<0.1$ & $<0.2$ & $<0.2$ & $<0.1$ & $<0.1$ & $<0.2$ \\
\hline $1 \mathrm{a}$ & $6 / 20 / 2005$ & $\mathrm{~s}$ & $<.1$ & $<.1$ & $<.2$ & $<.2$ & $<.1$ & $<.1$ & $<.2$ \\
\hline $1 \mathrm{a}$ & $6 / 20 / 2006$ & $r$ & $<.1$ & $<.1$ & $<.2$ & $<.2$ & $<.1$ & $<.1$ & $<.2$ \\
\hline $1 \mathrm{a}$ & $6 / 20 / 2006$ & $\mathrm{~s}$ & $<.1$ & $<.1$ & $<.2$ & $<.2$ & $<.1$ & $<.1$ & $<.2$ \\
\hline
\end{tabular}

${ }^{a}$ Laboratory reporting level for this constituent was greater at the time of analysis than the 2008 laboratory reporting level listed in table 9.

${ }^{b}$ Estimated values are concentrations measured between the laboratory reporting level and the long-term method detection level (Childress and others, 1999). 

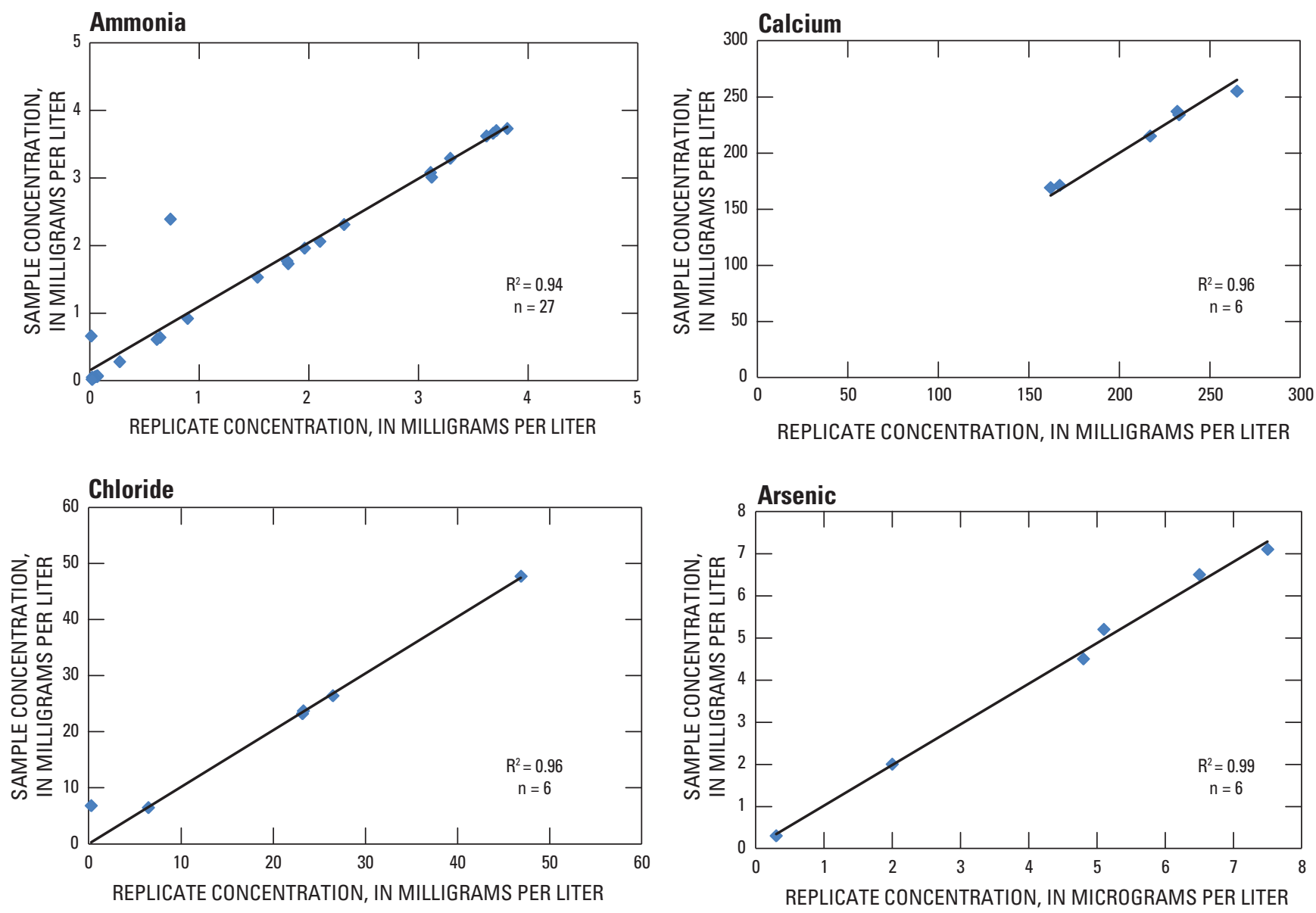

\section{EXPLANATION}

$\mathrm{R}^{2} \quad$ Coefficient of determination

n Number of replicate pairs

Figure 16. Selected quality assurance data for sample and replicate sample pairs. 


\section{Contributing Recharge Area and Groundwater Travel Time for the Independence Well Field}

The simulated CRA for the Independence well field for average annual river stage, rainfall, and 2007 well pumpage is elongated upstream and extends to both sides of the Missouri River (fig. 17). The capture of groundwater by the pumping wells as it moves downgradient toward the Missouri River causes the long up-valley extent of the CRA, especially north of the Missouri River. The alluvial valley walls south of the well field and the groundwater flow divide between flow to the Missouri River and flow to the Independence well field form the southern boundary of the CRA. Alluvial valley walls north of the well field and the groundwater flow divide between flow to the Liberty well field (located north of the Independence well field) and flow to the Independence well field form the northern boundary of the CRA. The western boundary of the CRA is the Missouri River although some small areas located farther to the west and adjacent to the Missouri River contribute some recharge to the well field. The eastern boundary of the CRA is formed by the alluvial valley walls to the east and south of the Missouri River and the groundwater flow divide between the Liberty well field and the Independence well field. The length of the CRA from west to east is about 13.6 kilometers $(\mathrm{km})$ and from north to south about $5.2 \mathrm{~km}$. The total area is about 37.18 square $\mathrm{km}$.

Groundwater velocity is affected by the groundwater gradient, hydraulic conductivity of the aquifer, and porosity. Groundwater velocity is faster with steeper gradient and constant hydraulic conductivity and porosity, with increased hydraulic conductivity and constant gradient and porosity, and with decreased porosity and constant hydraulic conductivity and gradient. The steepest groundwater gradients within the Missouri River alluvial aquifer in the model area were near supply wells and the Missouri River. Supply wells create a cone of depression on the potentiometric surface so that the groundwater gradient and groundwater velocity are greatest near a supply well. Rivers can produce large changes in groundwater gradient and direction as river altitude rises and falls. Hydraulic conductivity is smallest in clays and silts, larger in sands, and largest in gravels. Within the Missouri River alluvial aquifer in the model area, clay and silt overlie sand and gravel. Assuming a constant groundwater gradient, groundwater velocity increases with depth. Groundwater velocity is smaller in clay and silt, larger in sand, and largest in gravel, and because of the lithologic distribution within the alluvial aquifer this relation causes groundwater velocity to increase with depth. A typical map of groundwater travel time for a well located within an aquifer so that effects from any hydrologic boundary are negligible would have a bull's-eye pattern with shorter travel times in the center and longer travel times at the edges. The simulated groundwater travel time within the CRA to supply wells in the Independence well field is shown in figure 18.

\section{Individual Supply Wells of the Independence Well Field}

Pumping was simulated for the 40 supply wells of the Independence well field using average annual well pumpage from 2007 (table 7). Independence well-field pumpage is listed in table 7 and locations and identifiers of supply wells and monitoring well nests are shown on figure 2 .

Supply well CRAs were calculated using endpoint analysis for groundwater travel times less than 50 years, average river stage, and 2007 average annual pumping. The percentage of particles from the Missouri River or land surface indicates the relative contribution each of these make to the total flow to each well. The percentage of particles from the Missouri River and land surface, travel times, and size of the CRA for each well with a CRA for the Independence well field are listed in table 12.

CRAs calculated using only endpoint analysis resulted in no assignment of a CRA for wells 1A, 11, 30, and 38. A single particle on the surface of the topmost active cell characterized the CRA for most supply wells. The proximity of wells $1 \mathrm{~A}, 11,30$, and 38 to other supply wells, lower relative well pumpage for these wells, and the resolution of the model grid did not allow these wells to capture particles. Some CRAs include two supply wells. The CRA for well 4 includes well 2A, the CRA for well 14 includes well 13, and the CRA for well 27 includes well 3A. In these cases the wells are located in the same model cell and the CRA applies to the combined well pair.

Flow-path analysis provided additional information about CRAs and groundwater flow to individual supply wells of the Independence well field including wells 1A, 11, 30, and 38 . The CRAs calculated using endpoint analysis and groundwater flow paths calculated using flow-path analysis for average river stage and 2007 average annual pumping for each supply well are shown in figure 19. Wells 10 and 49 have the largest individual CRAs and form the outer-most boundary of the Independence well field CRA under simulated conditions. The large extent the CRAs for wells 10 and 49 indicate they obtain a large amount of recharge from rainfall that falls on the land surface. Supply wells located closer to the Missouri River, wells 7,15 , and 36 for example, receive much of their water induced from the river and have smaller CRAs than those wells recharged from the land surface because more water is available from the Missouri River bed per unit area than from the land surface. The percentage of particles from the Missouri River and land surface, and travel times calculated using flowpath analysis, for each supply well of the Independence well field are listed in table 13.

\section{Monitoring Wells of the Independence Well Field}

Sixty-eight monitoring wells in 29 well nests are located within and near the Independence well field (fig. 2). Water from these wells is regularly sampled by USGS personnel 


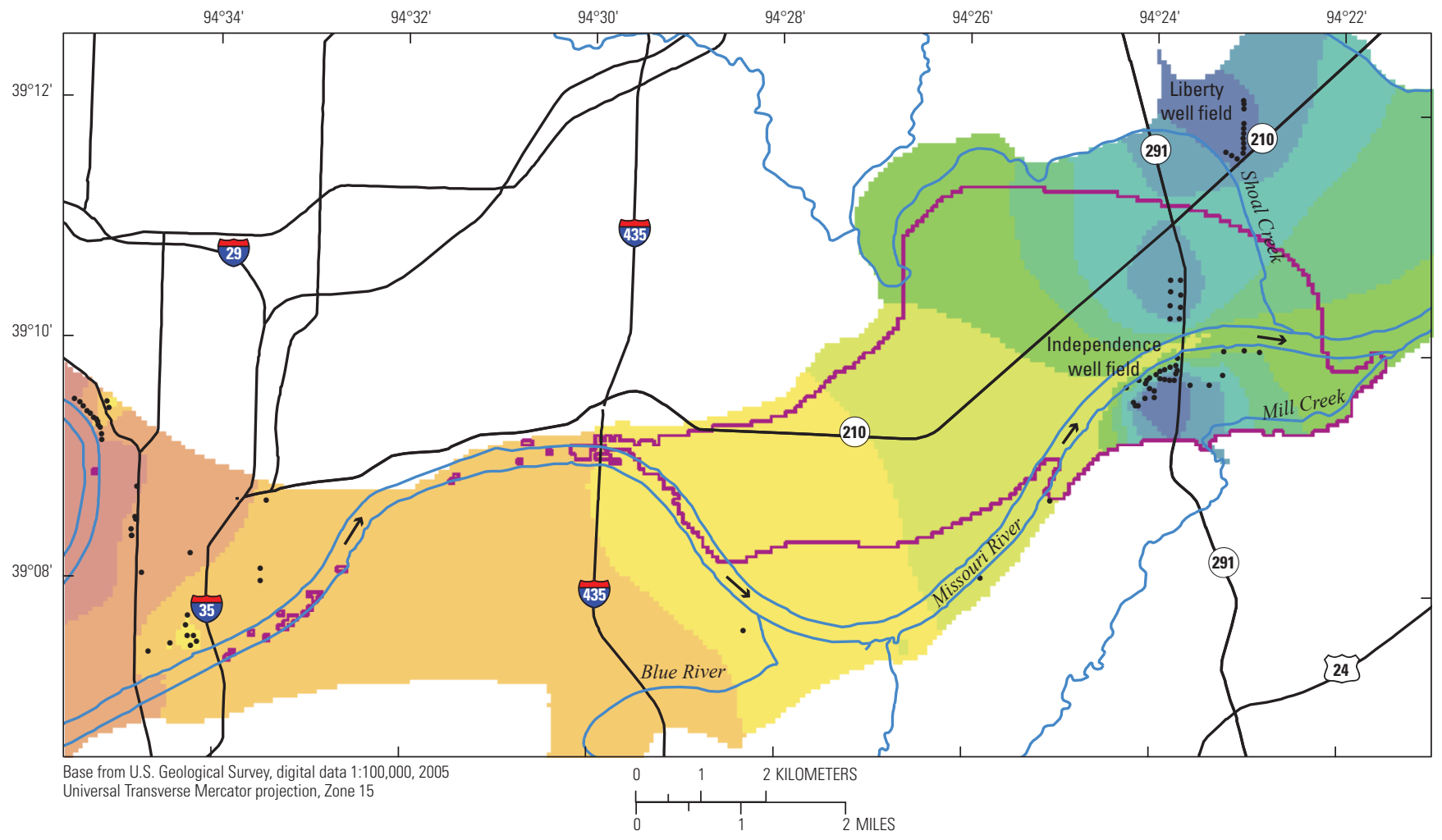

EXPLANATION

Groundwater altitude - Level at which water would have stood in a tightly cased well, in meters above the North American Vertical Datum of 1988 (NAVD88)

$[<$, less than; $>$, greater than $]$
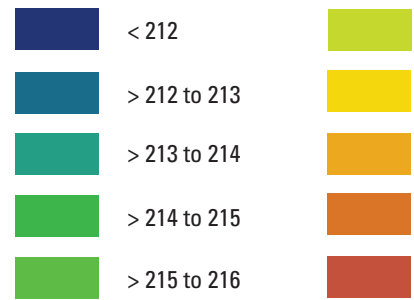

$>216$ to 217

$>217$ to 218

$>218$ to 219

$>219$ to 220

$>220$ to 221

Figure 17. Simulated groundwater altitude and contributing recharge area for the Independence well field. 

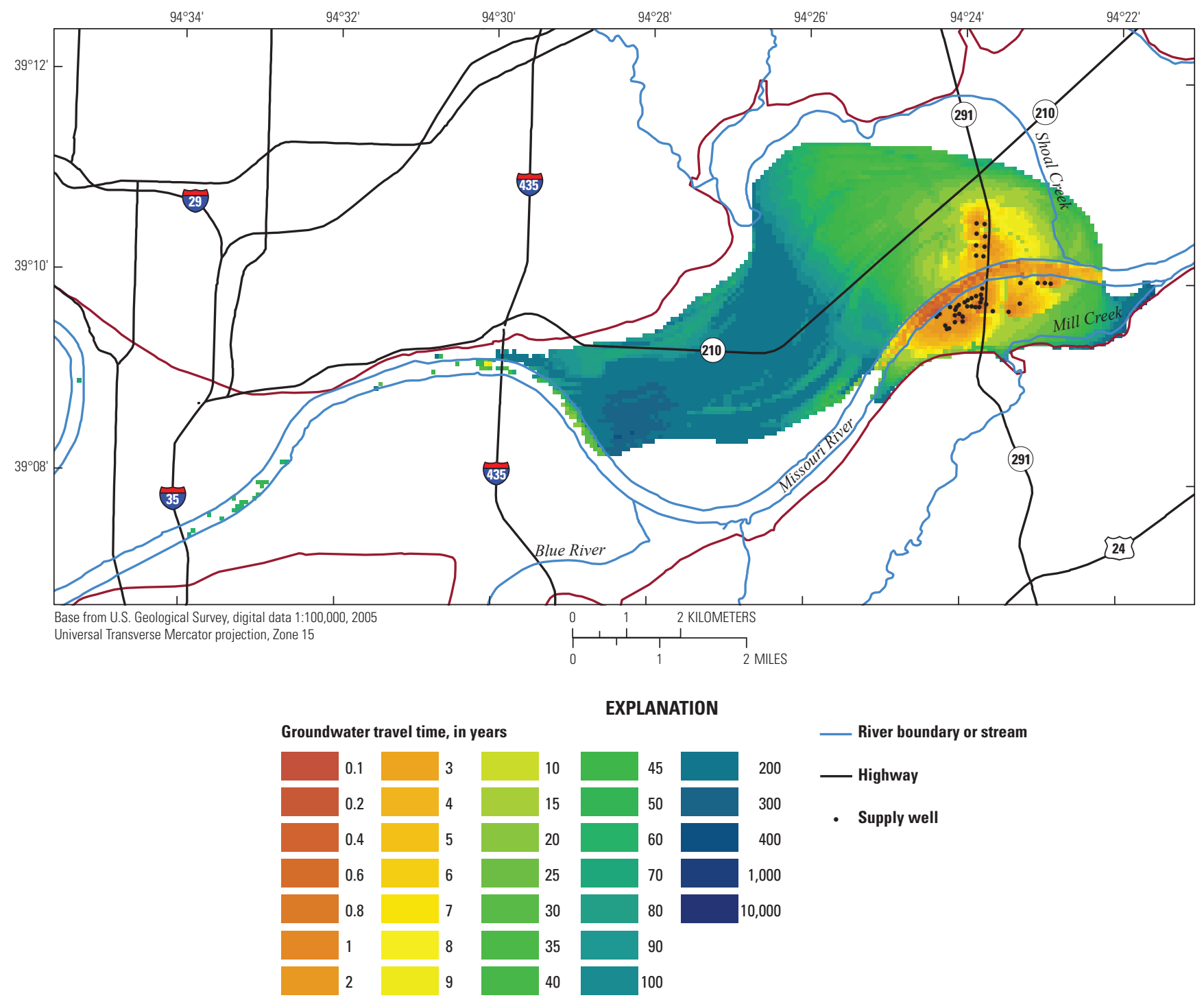

Figure 18. Simulated groundwater travel time within the contributing recharge area for the Independence well field. 
Table 12. Percentage of particles from the Missouri River and land surface, groundwater travel times, and size of the contributing recharge area for each supply well calculated using endpoint analysis.

[CRA, contributing recharge area; Min, minimum; Avg, average; Max, maximum; km², square kilometers]

\begin{tabular}{|c|c|c|c|c|c|c|}
\hline \multirow{2}{*}{$\begin{array}{l}\text { Supply well and CRA } \\
\text { (figs. } 2 \text { and 19) }\end{array}$} & \multicolumn{2}{|c|}{ Percentage of particles } & \multicolumn{3}{|c|}{$\begin{array}{l}\text { Travel time } \\
\text { (years) }\end{array}$} & \multirow[t]{2}{*}{$\begin{array}{r}\text { CRA } \\
\left(\mathrm{km}^{2}\right)\end{array}$} \\
\hline & Missouri River & Land surface & Min & Avg & Max & \\
\hline $4,2 \mathrm{~A}$ & 100 & 0.0 & 0.25 & 0.38 & 0.57 & 0.017 \\
\hline $5 \mathrm{~A}$ & 100 & 0 & .16 & .32 & .53 & .017 \\
\hline 7 & 100 & 0 & .42 & .42 & .42 & .006 \\
\hline 8 & 100 & 0 & .25 & .41 & .57 & .011 \\
\hline 9 & 22 & 78 & .22 & 3.48 & 10.3 & .416 \\
\hline 10 & 7 & 93 & .28 & 45 & 407 & 3.7 \\
\hline 12 & 100 & 0 & .47 & 1.18 & 2.5 & .045 \\
\hline 14,13 & 100 & 0 & .28 & .45 & .62 & .011 \\
\hline 15 & 100 & 0 & .25 & .25 & .25 & .006 \\
\hline 16 & 100 & 0 & .22 & .22 & .22 & .011 \\
\hline 17 & 100 & 0 & .22 & .57 & .91 & .023 \\
\hline 18 & 100 & 0 & .28 & .28 & .28 & .006 \\
\hline 19 & 50 & 50 & 1.95 & 1.99 & 2.02 & .006 \\
\hline 20 & 16 & 84 & .25 & 2.99 & 9.74 & .354 \\
\hline 22 & 100 & 0 & .68 & 1.18 & 1.45 & .045 \\
\hline 23 & 100 & 0 & .36 & .46 & .57 & .011 \\
\hline 24 & 100 & 0 & 1.21 & 2.52 & 3.75 & .028 \\
\hline $27,3 \mathrm{~A}$ & 100 & 0 & .35 & 1.92 & 3.39 & .034 \\
\hline 32 & 0 & 100 & .22 & .22 & .22 & .006 \\
\hline 33 & 100 & 0 & .88 & 1.32 & 2 & .023 \\
\hline 34 & 16 & 84 & .70 & 6.45 & 23.6 & .782 \\
\hline 35 & 100 & 0 & .75 & 1.76 & 2.96 & .045 \\
\hline 36 & 100 & 0 & .34 & .34 & .34 & .006 \\
\hline 39 & 58 & 42 & .72 & 2.43 & 11.5 & .101 \\
\hline 40 & 61 & 39 & .81 & 1.63 & 4.15 & .135 \\
\hline 41 & 95 & 5 & .06 & .34 & .88 & .113 \\
\hline 42 & 100 & 0 & .35 & .47 & .54 & .017 \\
\hline 43 & 26 & 74 & .27 & 3.81 & 16.7 & .293 \\
\hline 44 & 15 & 85 & .32 & 9.66 & 27.1 & .489 \\
\hline 45 & 7 & 93 & 2.94 & 22 & 100 & 1.22 \\
\hline 46 & 100 & 0 & .23 & .23 & .23 & .006 \\
\hline 47 & 24 & 76 & .67 & 6.82 & 11.7 & .146 \\
\hline 48 & 10 & 90 & .61 & 30.4 & 98.9 & 1.69 \\
\hline 49 & 4 & 97 & 1.72 & 146 & 562 & 27.4 \\
\hline
\end{tabular}



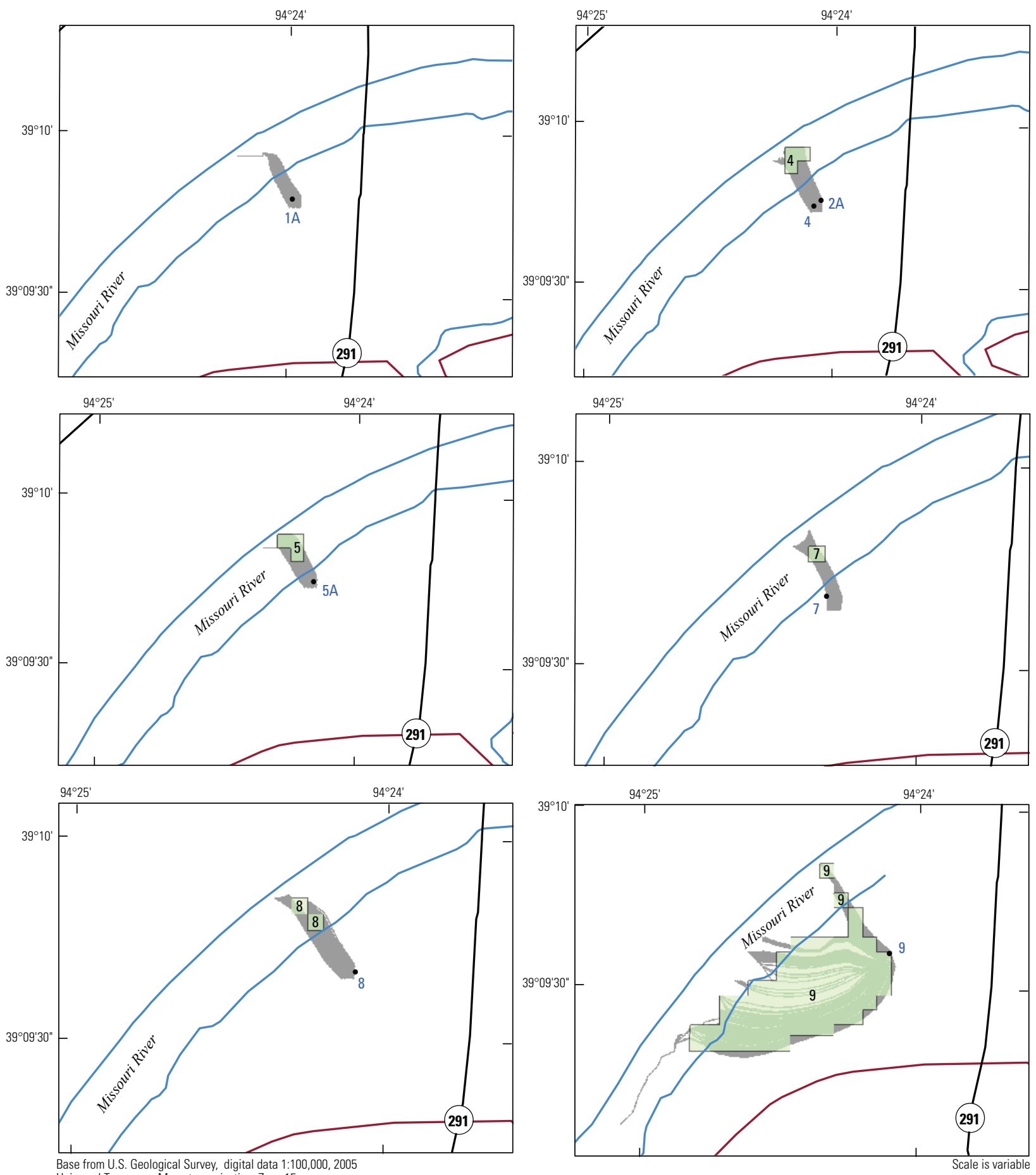
Base from U.S. Geological Survey, digital data $1.100,0$
Universal Transverse Mercator projection, Zone 15

\section{EXPLANATION}

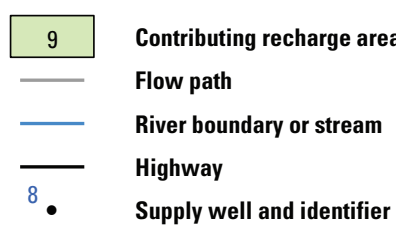

Figure 19. Contributing recharge areas calculated using endpoint analysis and groundwater flow paths calculated using flowpath analysis for each supply well of the Independence well field. 

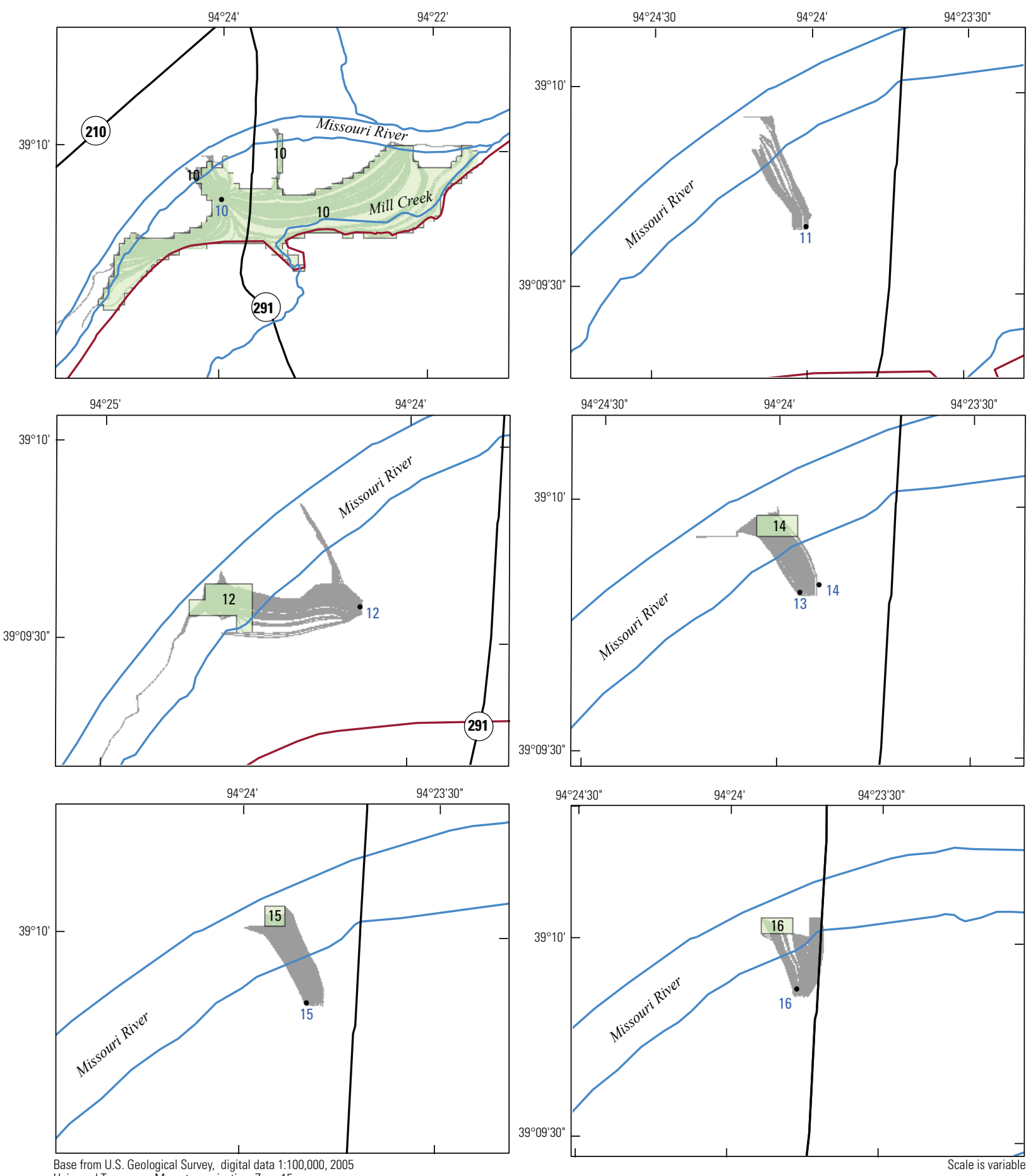
Universal Transverse Mercator projection, Zone 15
and

\section{EXPLANATION}

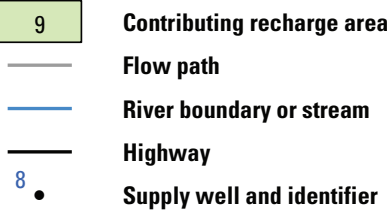

Figure 19. Contributing recharge areas calculated using endpoint analysis and groundwater flow paths calculated using flowpath analysis for each supply well of the Independence well field.-Continued 

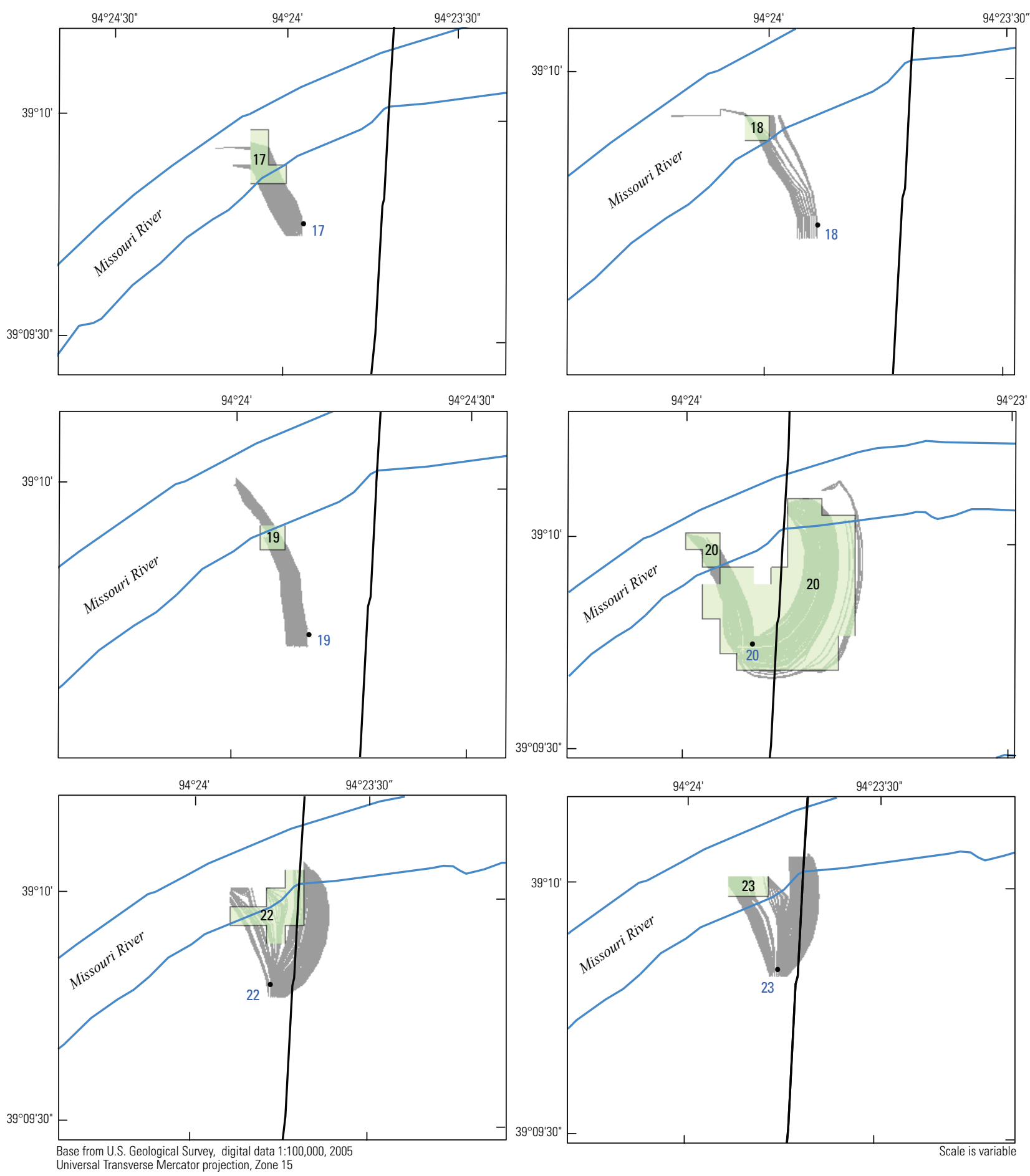

\section{EXPLANATION}

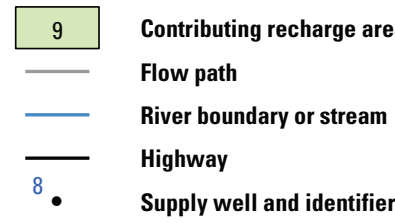

Figure 19. Contributing recharge areas calculated using endpoint analysis and groundwater flow paths calculated using flowpath analysis for each supply well of the Independence well field.-Continued 

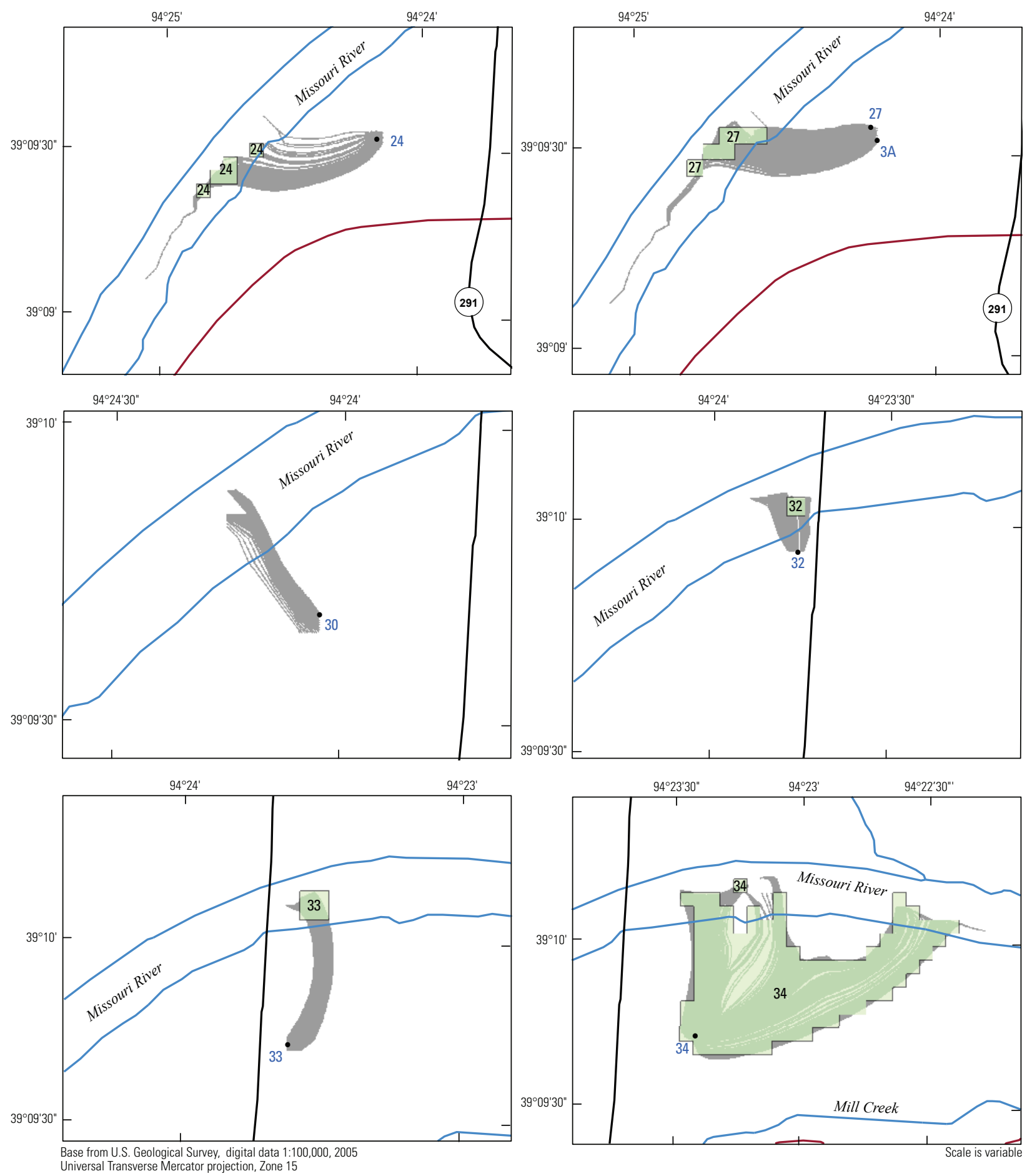

\section{EXPLANATION}

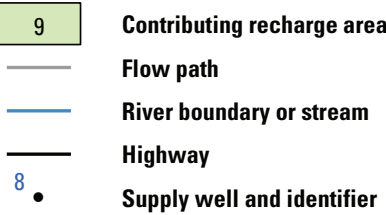

Figure 19. Contributing recharge areas calculated using endpoint analysis and groundwater flow paths calculated using flowpath analysis for each supply well of the Independence well field._- Continued 

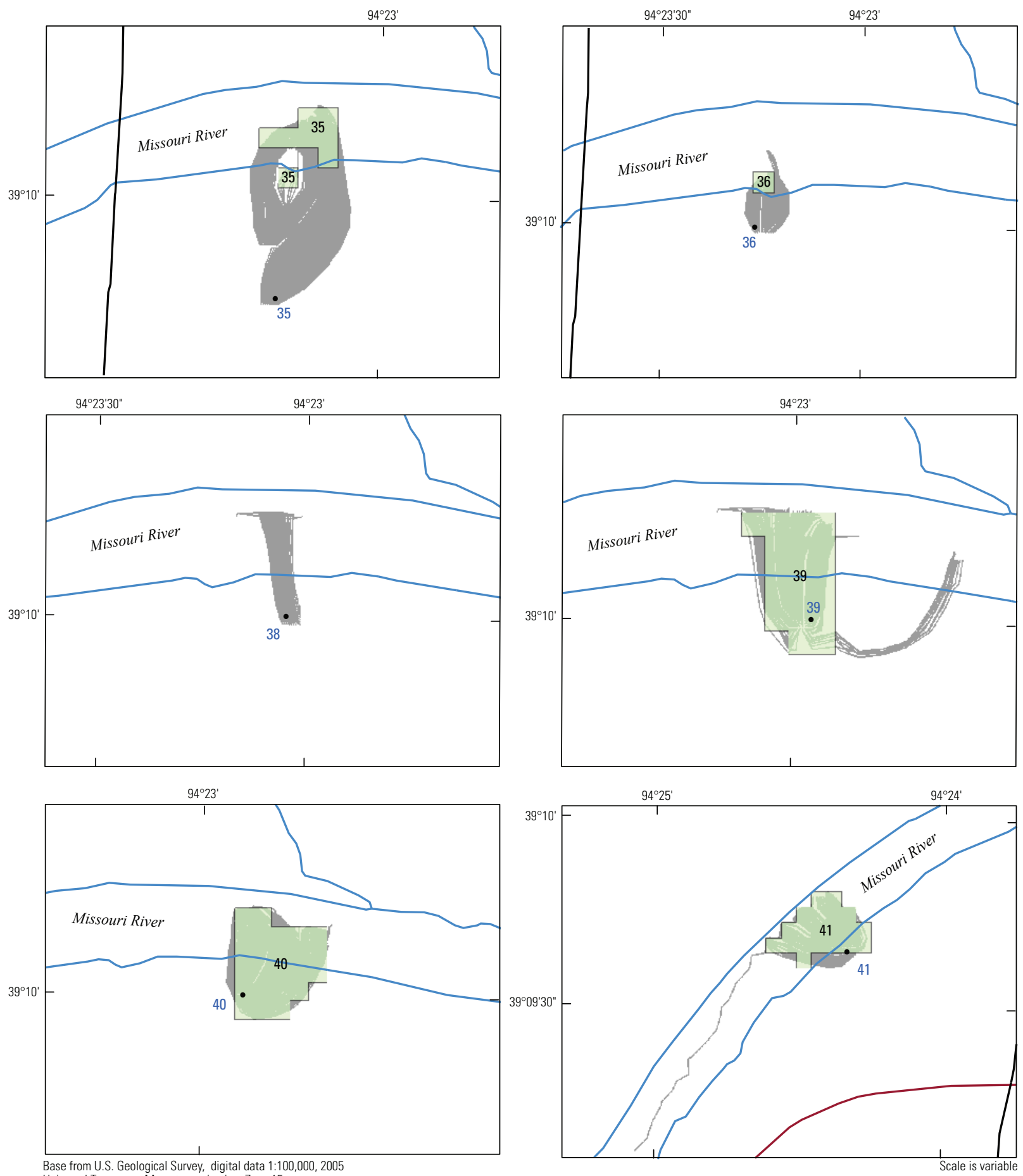

Universal Transverse Mercator projection, Zone 15

\section{EXPLANATION}

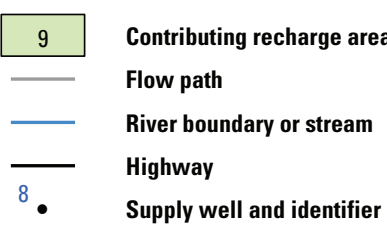

Figure 19. Contributing recharge areas calculated using endpoint analysis and groundwater flow paths calculated using flowpath analysis for each supply well of the Independence well field.-Continued 

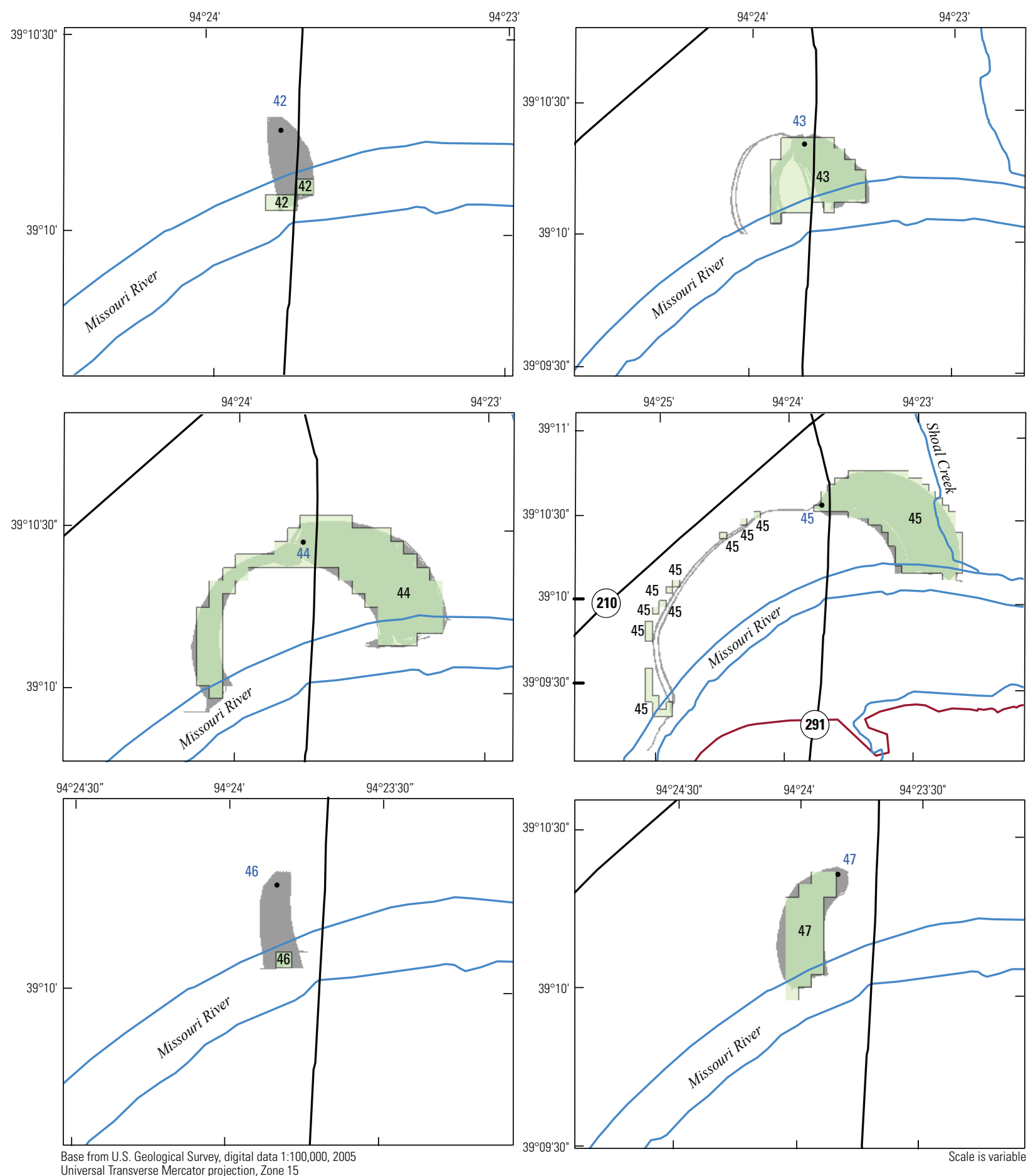

\section{EXPLANATION}

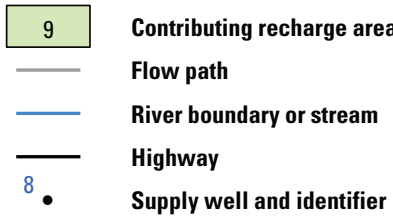

Figure 19. Contributing recharge areas calculated using endpoint analysis and groundwater flow paths calculated using flowpath analysis for each supply well of the Independence well field._- Continued 

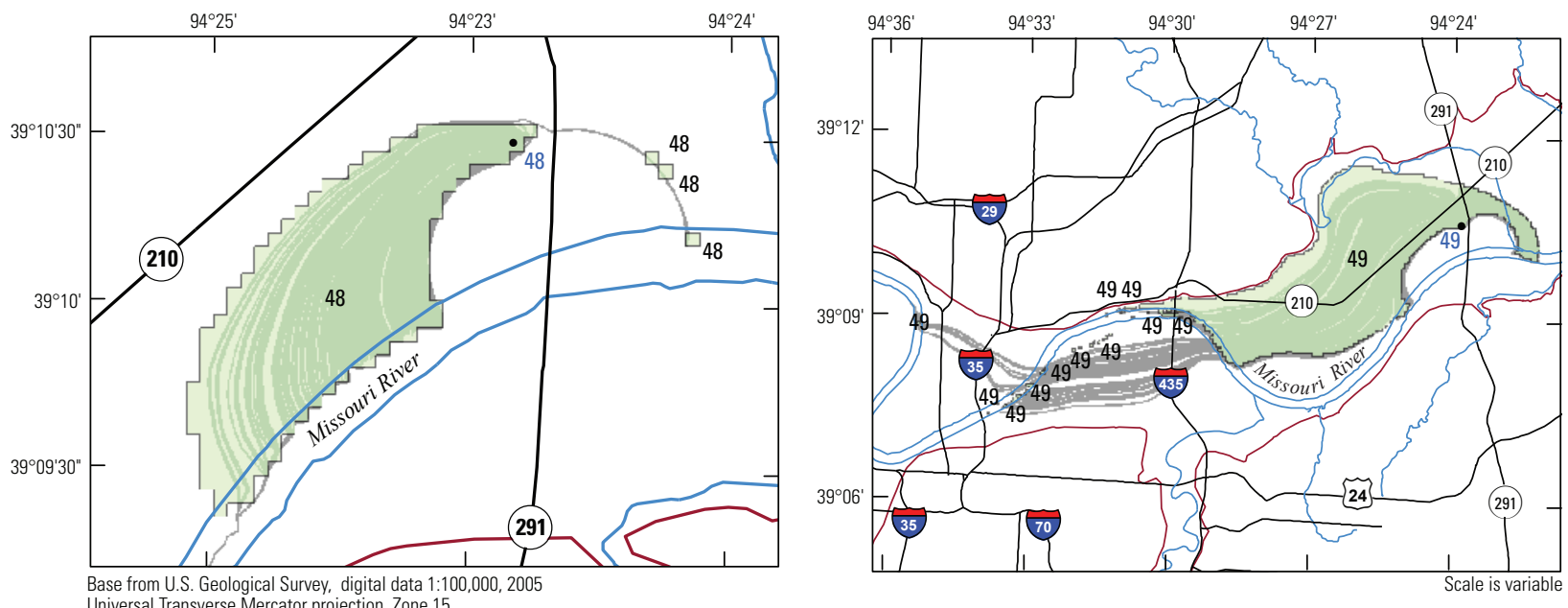

Base from U.S. Geological Survey, digital data 1:100,000, 2005

\section{EXPLANATION}

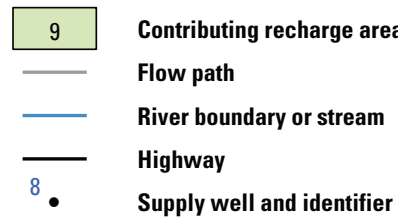

Figure 19. Contributing recharge areas calculated using endpoint analysis and groundwater flow paths calculated using flowpath analysis for each supply well of the Independence well field.-Continued 
Table 13. Percentage of particles from the Missouri River and land surface and groundwater travel times for each supply well calculated using flow-path analysis.

[CRA, contributing recharge area; Min, minimum; Avg, average; Max, maximum]

\begin{tabular}{|c|c|c|c|c|c|c|}
\hline \multirow{2}{*}{$\begin{array}{l}\text { Supply well and CRA } \\
\text { (figs. } 2 \text { and 19) }\end{array}$} & \multicolumn{3}{|c|}{ Percentage of particles } & \multicolumn{3}{|c|}{$\begin{array}{c}\text { Groundwater travel time } \\
\text { (years) }\end{array}$} \\
\hline & Missouri River & Land surface & $\begin{array}{l}\text { Other pumping } \\
\text { well cells }\end{array}$ & Min & Avg & Max \\
\hline $1 \mathrm{~A}$ & 100.0 & & & 52.70 & 59.60 & 61.10 \\
\hline $4,2 \mathrm{~A}$ & 100.0 & & & .09 & 5.31 & 12.20 \\
\hline $5 \mathrm{~A}$ & 100.0 & & & .15 & 13.60 & 22.60 \\
\hline 7 & 100.0 & & & .07 & .27 & 0.62 \\
\hline 8 & 45.5 & & 54.5 & .03 & .36 & 2.07 \\
\hline 9 & 72.2 & .1 & 27.7 & .01 & 22.70 & 981.00 \\
\hline 10 & 70.5 & 1.9 & 27.6 & .00 & 14.90 & 298.00 \\
\hline 11 & 23.5 & & 76.5 & .01 & 2.72 & 14.70 \\
\hline 12 & 96.7 & & 3.3 & .02 & 87.00 & 980.82 \\
\hline 14,13 & 100.0 & & & .09 & 53.10 & 61.59 \\
\hline 15 & 100.0 & & & .09 & .43 & 1.21 \\
\hline 16 & 67.8 & & 32.2 & .01 & .56 & 2.20 \\
\hline 17 & 100.0 & & & 1.52 & 49.80 & 61.30 \\
\hline 18 & 53.9 & & 46.1 & .04 & 30.00 & 61.60 \\
\hline 19 & 88.9 & & 11.1 & .03 & .48 & .87 \\
\hline 20 & 80.8 & & 19.2 & .01 & 2.61 & 9.76 \\
\hline 22 & 74.2 & & 25.8 & .00 & 1.05 & 3.68 \\
\hline 23 & 53.4 & & 46.6 & .00 & .37 & 2.51 \\
\hline 24 & 66.7 & & 33.3 & .01 & 67.40 & 980.00 \\
\hline $27,3 \mathrm{~A}$ & 100.0 & & & .16 & 39.20 & 979.00 \\
\hline 30 & 47.0 & & 53.0 & .01 & .31 & 1.44 \\
\hline 32 & 100.0 & & & .03 & 1.15 & 22.10 \\
\hline 33 & 100.0 & & & .46 & 1.69 & 4.79 \\
\hline 34 & 98.8 & 1.1 & .1 & .27 & 12.30 & 72.40 \\
\hline 35 & 99.1 & & .9 & .10 & 2.84 & 40.20 \\
\hline 36 & 100.0 & & & .04 & .16 & 15.00 \\
\hline 38 & 100.0 & & & 3.13 & 16.10 & 48.60 \\
\hline 39 & 100.0 & & & .21 & 12.60 & 63.40 \\
\hline 40 & 99.9 & .1 & & .26 & 8.72 & 95.30 \\
\hline 41 & 95.5 & 1.0 & 3.6 & .00 & 54.80 & 169.00 \\
\hline 42 & 100.0 & & & .09 & 2.05 & 9.72 \\
\hline 43 & 98.1 & .4 & 1.5 & .10 & 1.15 & 12.50 \\
\hline 44 & 99.9 & .1 & & .35 & 19.30 & 62.80 \\
\hline 45 & 99.6 & .4 & & .44 & 10.60 & 118.00 \\
\hline 46 & 100.0 & & & .51 & 5.58 & 22.20 \\
\hline 47 & 100.0 & & & .19 & .71 & 6.37 \\
\hline 48 & 100.0 & & & .49 & 45.80 & 210.00 \\
\hline 49 & 97.4 & 2.6 & & 1.45 & 83.00 & $1,060.00$ \\
\hline
\end{tabular}


for selected water-quality constituents as part of a wellhead protection plan the City of Independence follows to assess the quality of the water supply (City of Independence, Missouri, 2003). Monitoring well identifiers used in previous reports (Kelly, 1996b, 2002a, 2002b, 2006) were based on a well nest number and a designation of the simulated groundwater travel time from the screened interval of each monitoring well to the well field (Kelly, 1996b). For example, well 1-5 yr is part of well nest 1 and had a 5-year simulated groundwater travel time from the monitoring well to the well field (based on Kelly, 1996b). The City of Independence has assigned other identifiers to the monitoring well network. For example, well $1-5 \mathrm{yr}$ is designated well 1a. Installation of new wells, changes in well pumpage, and the resulting change in groundwater travel times to supply wells has obviated the original monitoring well identifiers. For this report, the monitoring well identifiers adopted by the City of Independence are used. Monitoring well identifier, previous monitoring well identifier (for reference purposes), land-surface altitude, and well depth are listed in table 14. The "a", "b", and "c" designation in the monitoring well identifiers indicates relative depth of the well in each well nest with "a" the deepest well, "b" the next deepest, and "c" the next deepest. This relation is different for well nest 4. Well $4 \mathrm{a}$ is deepest, $4 \mathrm{c}$, next deepest, and $4 \mathrm{~b}$ the next deepest.

Groundwater flow paths (fig. 20) and CRAs estimated for monitoring wells using flow-path analysis indicate the origin of water to each monitoring well, the travel time of that water from the recharge area, the flow path from the vicinity of each monitoring well to a supply well, and the travel time from the monitoring well to the supply well. Groundwater flow in the Missouri River alluvial aquifer is three-dimensional, and shallow flow path features can mask flow directions deeper in the aquifer. Additional details of groundwater flow paths were determined with an analysis of groundwater flow paths from monitoring well recharge areas to monitoring wells for each layer of the model. The area where particles from each monitoring well stopped (either at the Missouri River or land surface) defined a polygon. Results, grouped by layer, are shown in figure 21.

The percentage of particles from the Missouri River and land surface, and groundwater travel times from monitoring well CRAs to each monitoring well are listed in table 15 . Monitoring well 14a and $14 \mathrm{~b}$ have the shortest minimum travel time of 0.30 years, monitoring well $19 \mathrm{a}$ has the shortest average travel time of 1.68 years, and monitoring well $17 \mathrm{~b}$ has the shortest maximum travel time of 3.19 years. Monitoring well 16a has the longest minimum travel time of 159.00 years, monitoring well $27 \mathrm{~b}$ has the longest average travel time of 193.30 years, and monitoring well 29a has the longest maximum travel time of $1,701.00$ years.

Groundwater flow paths and travel times were also determined from each monitoring well to each supply well for each layer of the model using flow-path analysis (fig. 22). As before, monitoring wells were grouped by the model layer that contained the screened interval for the well. The percentage of particles from each monitoring well that ended in each supply well and groundwater travel times calculated using endpoint analysis are compiled in table 16. Groundwater flow from 23 of the monitoring wells to more than one supply well illustrates the effect of multiple supply wells on groundwater flow near the well field.

Monitoring well 22a has the shortest minimum travel time of 0.00 year ( 0.5 day) to supply well 44 and shortest average travel time of 0.01 year to supply well 44 , and monitoring well 23a has the shortest maximum travel time of 0.04 year to supply well 44 . Monitoring well $3 \mathrm{~b}$ has the longest minimum travel time of 9.65 years to supply well 10, monitoring well $16 \mathrm{~b}$ has the longest average travel time of 16.77 years to supply well 48 , and monitoring well $3 \mathrm{~b}$ has the longest maximum travel time of 31.91 years to supply well 10 .

\section{Hydrologic Controls on Contributing Recharge Areas}

The size and shape of the CRA for each Independence supply well and monitoring well is complex. Each supply well has a unique position with respect to the geometry of the aquifer, the alluvial valley walls, the Missouri River, the distribution of hydraulic conductivity, and other supply wells in the well field, or a unique pumping rate. Supply well 49, without relatively nearby hydrologic boundaries such as the Missouri River, has a large CRA because groundwater in the simulation travelled a long distance along the flow gradient before it was captured and discharged by the well. Wells located closer to the Missouri River, for example supply well 7, have small CRAs that intersect the Missouri River bed because a large amount of induced recharge is available. Wells located closer to the alluvial valley walls have CRAs that extend away from the valley walls because the amount of water available to the well is limited from this low-flow or no-flow boundary.

The vertical conductance limits water flow between layers of the model to simulate the vertical anisotropy of hydraulic conductivity within the alluvial aquifer. This anisotropy is greatest in the heterogeneously distributed clay, silty clay, and silt present at shallow depths and represented in the model by layer 1 . The distribution of vertical conductance between layers 1 and 2 affects the distribution of groundwater travel times within the CRA of each well. A low rate of vertical water movement caused by the presence of clay or silt near the land surface increases the travel time of water from the top of the water table to deeper parts of the aquifer. Because the hydraulic conductivity values in the deeper parts of the aquifer are higher and more uniformly distributed, the rate of water movement is faster and more uniform than the rate in shallower parts of the aquifer. Therefore, the rate of water flow downward to the deeper parts of the aquifer has a large effect on the travel time of water from the water table to the screened interval of a supply well and on the distribution of the CRA of a well or well field.

Interference among supply wells within the well field also affects the size and shape of the CRA for each well. Wells 
Table 14. Monitoring well identifier, previous monitoring well identifier, land surface altitude, and well depth.

[a, b, c in identifier indicates relative depth of the well in each nest from "a" the deepest to "c" the shallowest. For well nest 4, 4a is deepest, 4c is intermediate, and $4 \mathrm{~b}$ is shallowest; $\mathrm{m}$, meter]

\begin{tabular}{|c|c|c|c|c|c|c|c|}
\hline $\begin{array}{l}\text { Monitoring } \\
\text { well identifier } \\
\text { (fig. 2) }\end{array}$ & $\begin{array}{c}\text { Previous } \\
\text { monitoring well } \\
\text { identifier } \\
\text { (Kelly, 2002a) }\end{array}$ & $\begin{array}{l}\text { Land surface } \\
\text { altitude above } \\
\text { North } \\
\text { American } \\
\text { Vertical Datum } \\
\text { of } 1988 \\
\text { (m) }\end{array}$ & $\begin{array}{c}\text { Well } \\
\text { depth } \\
(\mathrm{m})\end{array}$ & $\begin{array}{c}\text { Monitoring } \\
\text { well identifier } \\
\text { (fig. 2) }\end{array}$ & $\begin{array}{c}\text { Previous } \\
\text { monitoring well } \\
\text { identifier } \\
\text { (Kelly, 2002a) }\end{array}$ & $\begin{array}{l}\text { Land surface } \\
\text { altitude above } \\
\text { North } \\
\text { American } \\
\text { Vertical Datum } \\
\text { of } 1988 \\
\text { (m) }\end{array}$ & $\begin{array}{c}\text { Well } \\
\text { depth } \\
\text { (m) }\end{array}$ \\
\hline 1a & $1-5 \mathrm{yr}$ & 222.49 & 22.3 & $15 b$ & $15-2 \mathrm{yr}$ & 220.19 & 17.7 \\
\hline $1 \mathrm{~b}$ & $1-10 \mathrm{yr}$ & 222.49 & 11.9 & $16 \mathrm{a}$ & $16-5 \mathrm{yr}$ & 224.13 & 24.7 \\
\hline $3 a$ & $3-3 y r$ & 223.78 & 20.4 & $17 \mathrm{~b}$ & $17-2 \mathrm{yr}$ & 220.04 & 6.1 \\
\hline $3 b$ & $3-10 y r$ & 223.78 & 14.6 & $18 \mathrm{a}$ & $18-0.5 \mathrm{yr}$ & 220.32 & 16.5 \\
\hline $4 a$ & $4-1 \mathrm{yr}$ & 224.17 & 25.9 & $18 \mathrm{~b}$ & $18-2 \mathrm{yr}$ & 220.32 & 6.7 \\
\hline $4 \mathrm{~b}$ & $4-3 y r$ & 224.17 & 12.2 & $19 a$ & $19-0.5 \mathrm{yr}$ & 222.27 & 16.5 \\
\hline $4 c$ & $4-5 y r$ & 224.17 & 16.5 & $19 \mathrm{~b}$ & $19-1 \mathrm{yr}$ & 222.27 & 8.2 \\
\hline $5 \mathrm{a}$ & $5-4 y r$ & 231.85 & 27.1 & $20 \mathrm{a}$ & $20-0.5 \mathrm{yr}$ & 220.72 & 16.5 \\
\hline $8 a$ & $8-0.5 \mathrm{yr}$ & 223.21 & 18.3 & $22 b$ & $22-2 \mathrm{yr}$ & 223.02 & 12.2 \\
\hline $8 \mathrm{~b}$ & $8-2 \mathrm{yr}$ & 223.21 & 15.8 & $22 c$ & $22-3 \mathrm{yr}$ & 223.02 & 10.4 \\
\hline $9 \mathrm{a}$ & $9-0.5 \mathrm{yr}$ & 221.45 & 15.8 & $23 a$ & $23-1 \mathrm{yr}$ & 224.25 & 33.5 \\
\hline $9 \mathrm{~b}$ & $9-2 \mathrm{yr}$ & 221.45 & 11.6 & $23 \mathrm{~b}$ & $23-3 \mathrm{yr}$ & 224.25 & 26.2 \\
\hline $9 \mathrm{c}$ & $9-5 \mathrm{yr}$ & 221.45 & 9.8 & $23 \mathrm{c}$ & $23-10 y r$ & 224.25 & 14.6 \\
\hline $10 \mathrm{a}$ & $10-0.5 \mathrm{yr}$ & 221.04 & 16.8 & $24 a$ & $24-1 \mathrm{yr}$ & 222.09 & 36.9 \\
\hline $10 \mathrm{~b}$ & $10-2 \mathrm{yr}$ & 221.04 & 13.1 & $24 \mathrm{~b}$ & $24-3 y r$ & 222.09 & 24.4 \\
\hline $10 \mathrm{c}$ & $10-5 \mathrm{yr}$ & 221.04 & 9.8 & $24 \mathrm{c}$ & $24-5 \mathrm{yr}$ & 222.09 & 9.1 \\
\hline $11 \mathrm{a}$ & $11-0.5 \mathrm{yr}$ & 222.45 & 17.4 & $25 a$ & $25-3 \mathrm{yr}$ & 220.26 & 31.7 \\
\hline $11 \mathrm{~b}$ & $11-1 \mathrm{yr}$ & 222.45 & 15.2 & $25 \mathrm{~b}$ & $25-5 y r$ & 220.26 & 32.6 \\
\hline $11 \mathrm{c}$ & $11-3 \mathrm{yr}$ & 222.45 & 11.0 & $25 \mathrm{c}$ & $25-10 y r$ & 220.26 & 20.7 \\
\hline $12 a$ & $12-0.5 \mathrm{yr}$ & 221.71 & 14.0 & $26 a$ & $26-2 \mathrm{yr}$ & 220.87 & 31.1 \\
\hline $12 b$ & $12-3 \mathrm{yr}$ & 221.71 & 12.5 & $26 b$ & $26-5 \mathrm{yr}$ & 220.87 & 26.8 \\
\hline
\end{tabular}




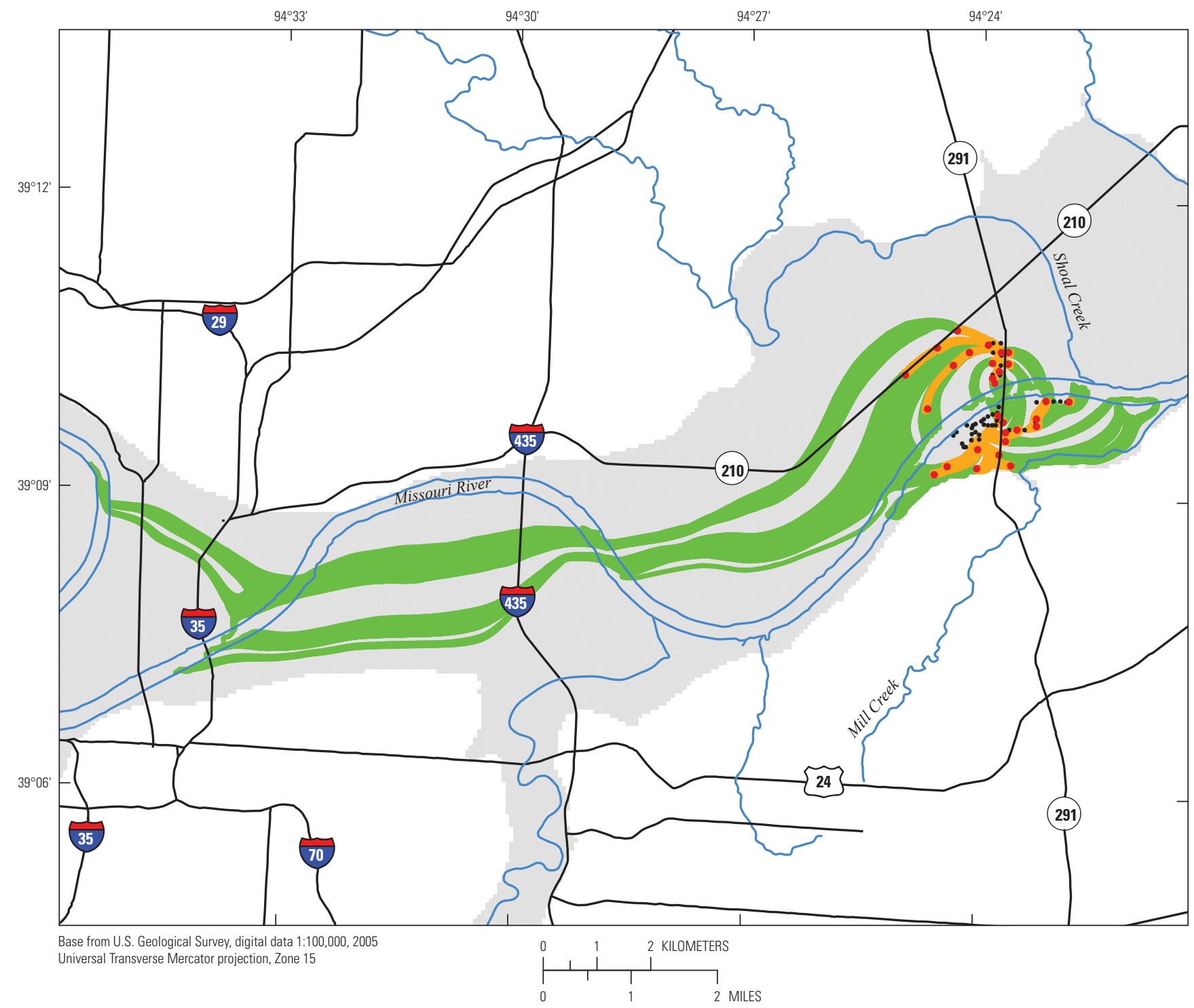

EXPLANATION

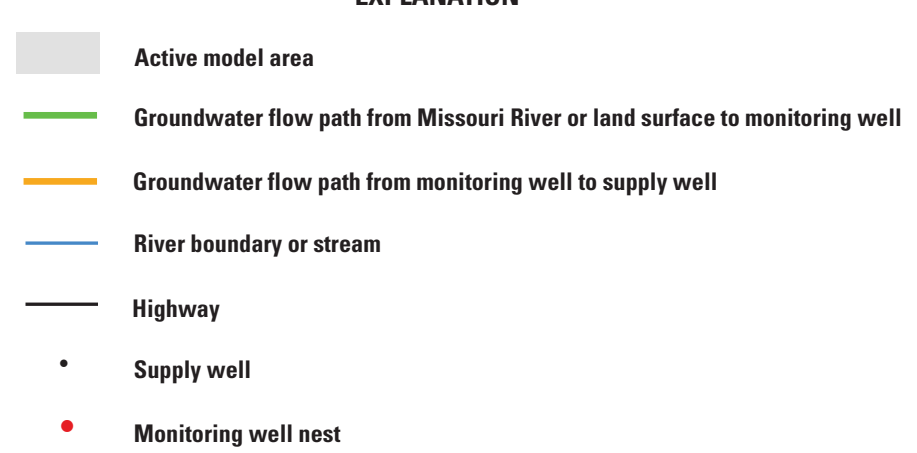

Figure 20. Groundwater flow paths from the Missouri River or land surface to monitoring wells and from monitoring wells to supply wells of the Independence well field. 


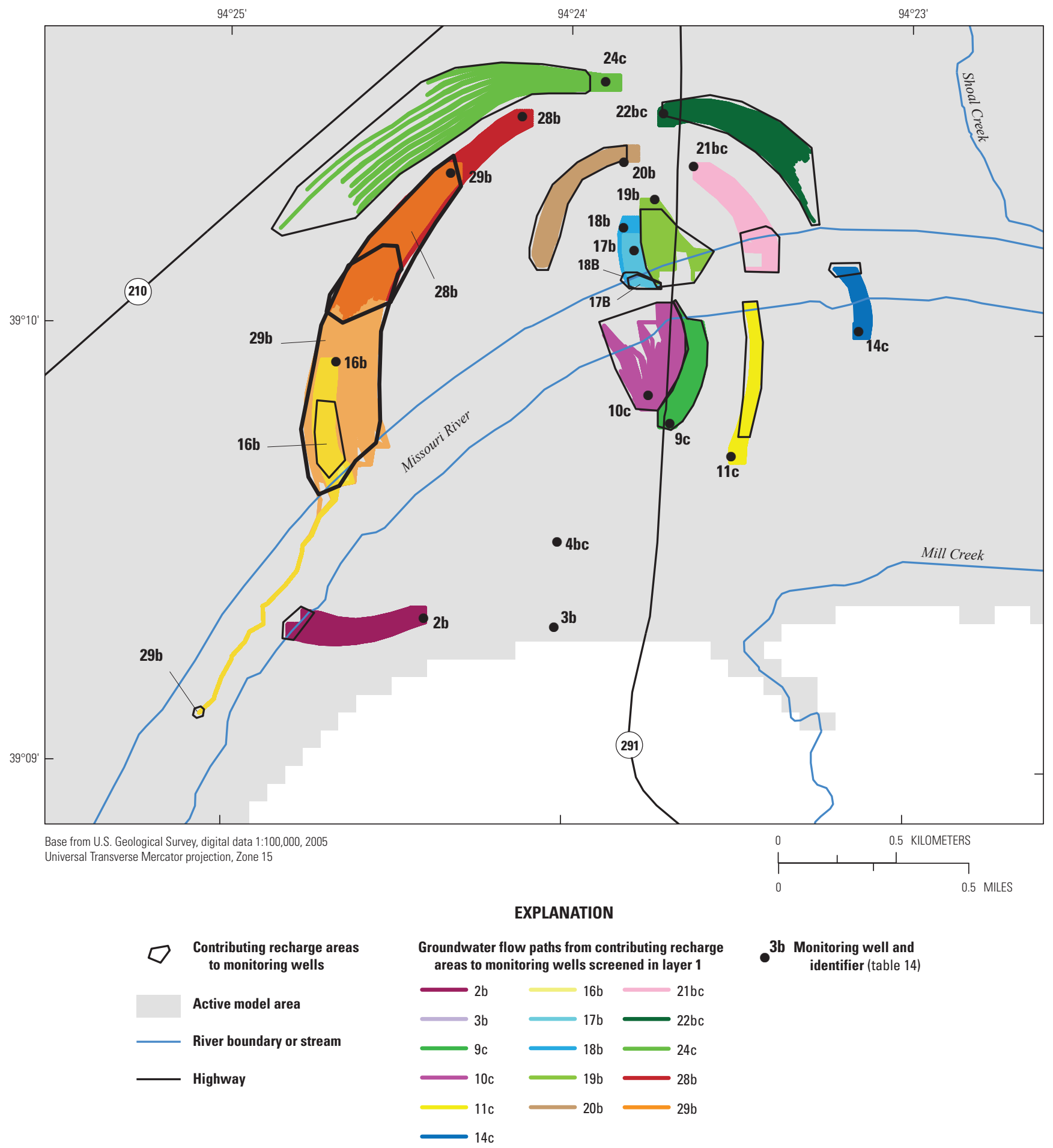

Figure 21. Contributing recharge areas and groundwater flow paths from contributing recharge areas to monitoring wells grouped by model layer for the Independence well field. 


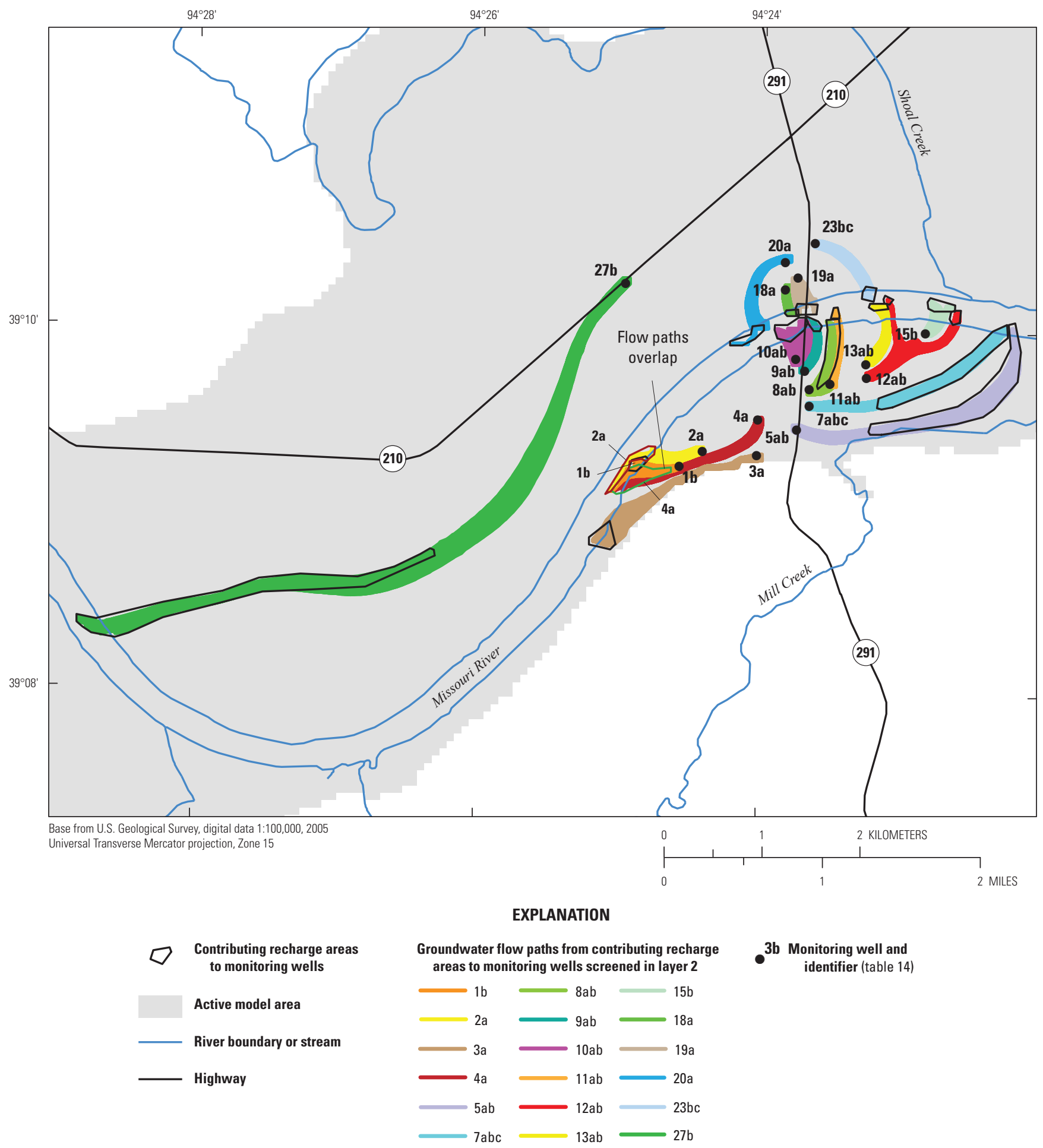

Figure 21. Contributing recharge areas and groundwater flow paths from contributing recharge areas to monitoring wells grouped by model layer for the Independence well field.-Continued 


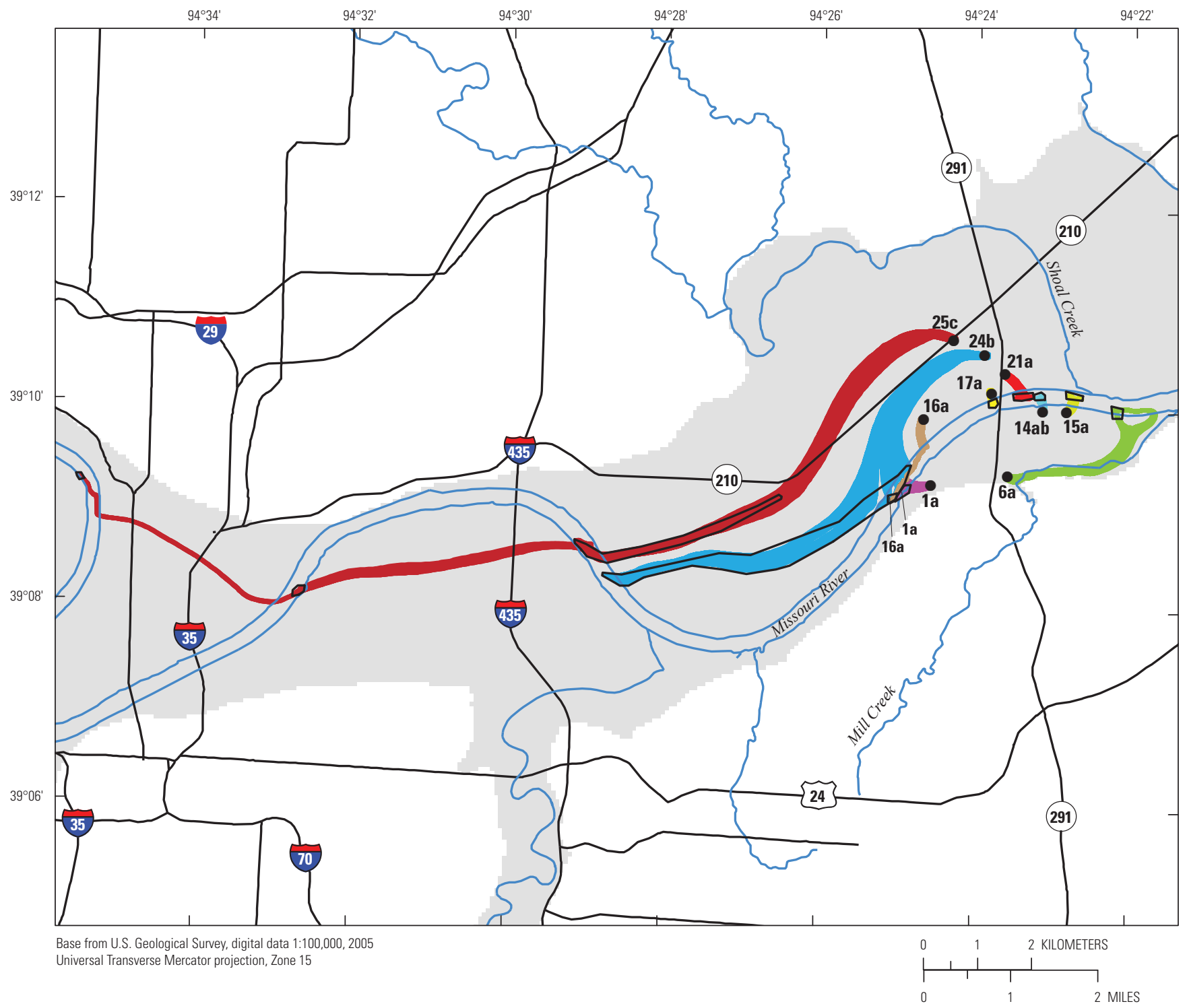

EXPLANATION

$\square$ Contributing recharge areas to monitoring wells

Groundwater flow paths from contributing recharge areas to monitoring wells screened in layer 3

Active model area

1a 15a 21a

$-6 a-16 a-24 b$

River boundary or stream

$-14 a b-17 a-25 c$ 3b Monitoring well and identifier (table 14)

\section{Highway}

Figure 21. Contributing recharge areas and groundwater flow paths from contributing recharge areas to monitoring wells grouped by model layer for the Independence well field.-Continued 


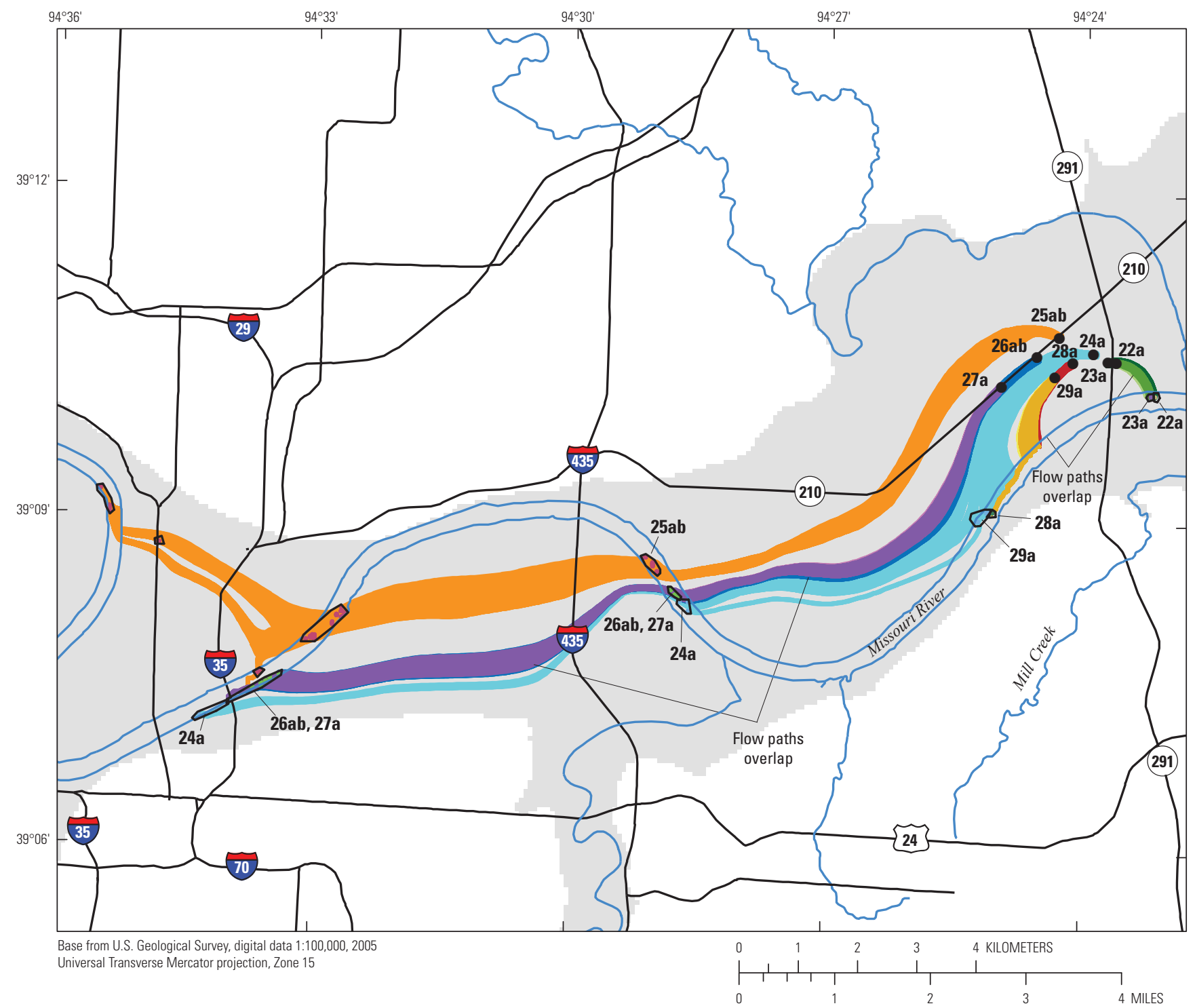

EXPLANATION

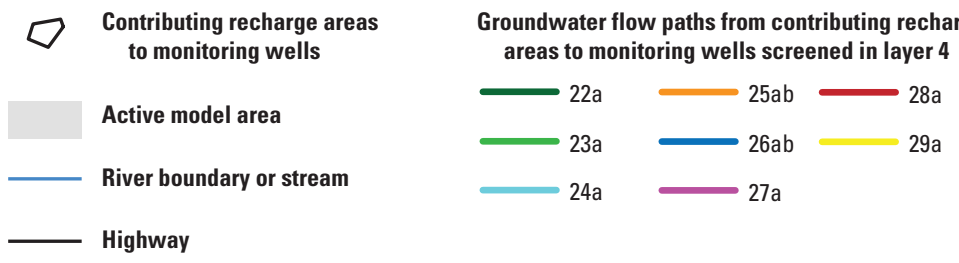

Figure 21. Contributing recharge areas and groundwater flow paths from contributing recharge areas to monitoring wells grouped by model layer for the Independence well field.-Continued 
Table 15. Monitoring well, percentage of particles from the Missouri River and land surface, and groundwater travel times from monitoring well contributing recharge areas to each monitoring well.

[a, $b, c$ in identifier indicates relative depth of the well in each nest from "a" the deepest to "c" the shallowest. For well nest 4, 4a is deepest, 4c is intermediate, and $4 \mathrm{~b}$ is shallowest; Min, minimum; Avg, average; Max, maximum]

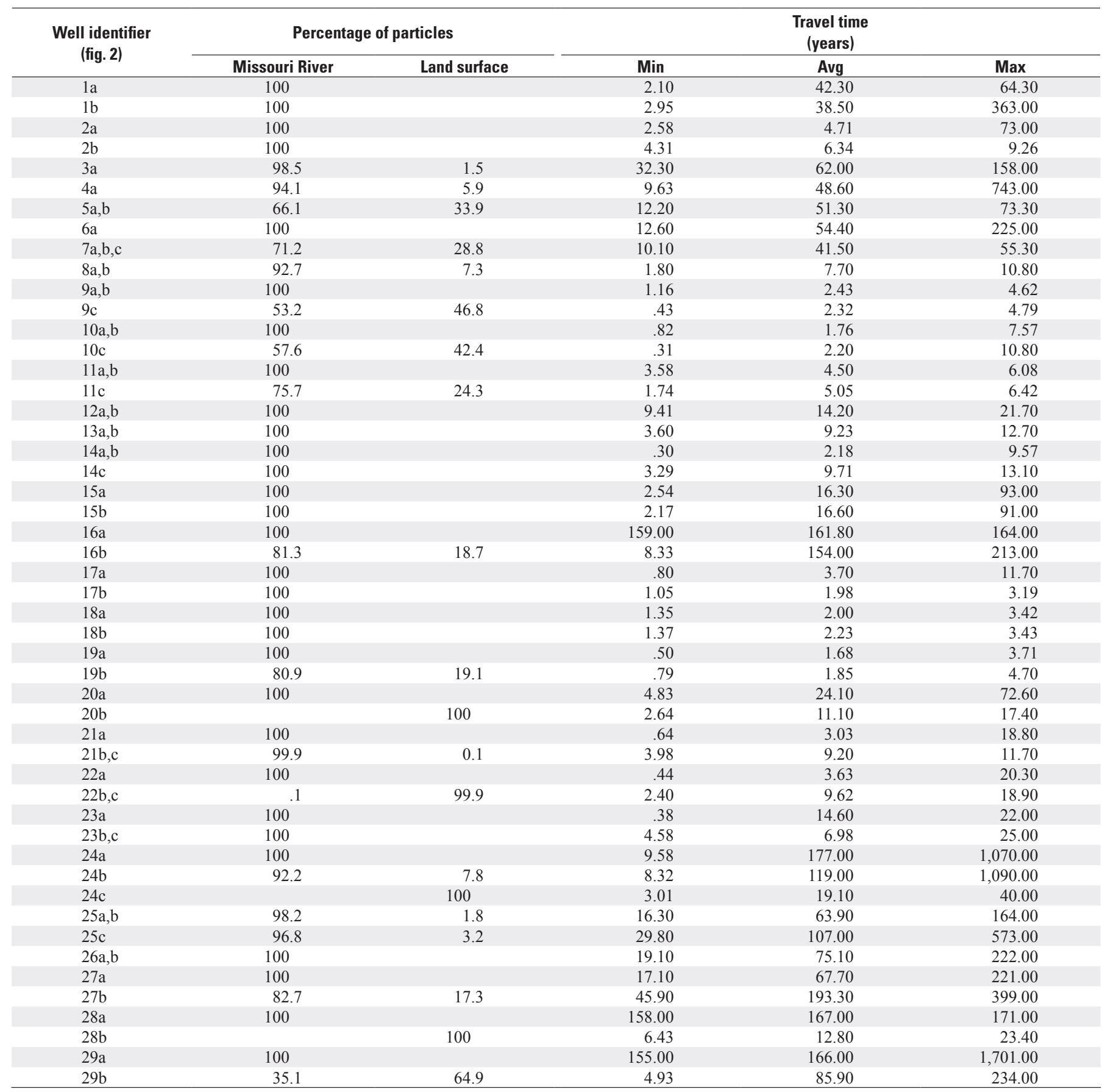




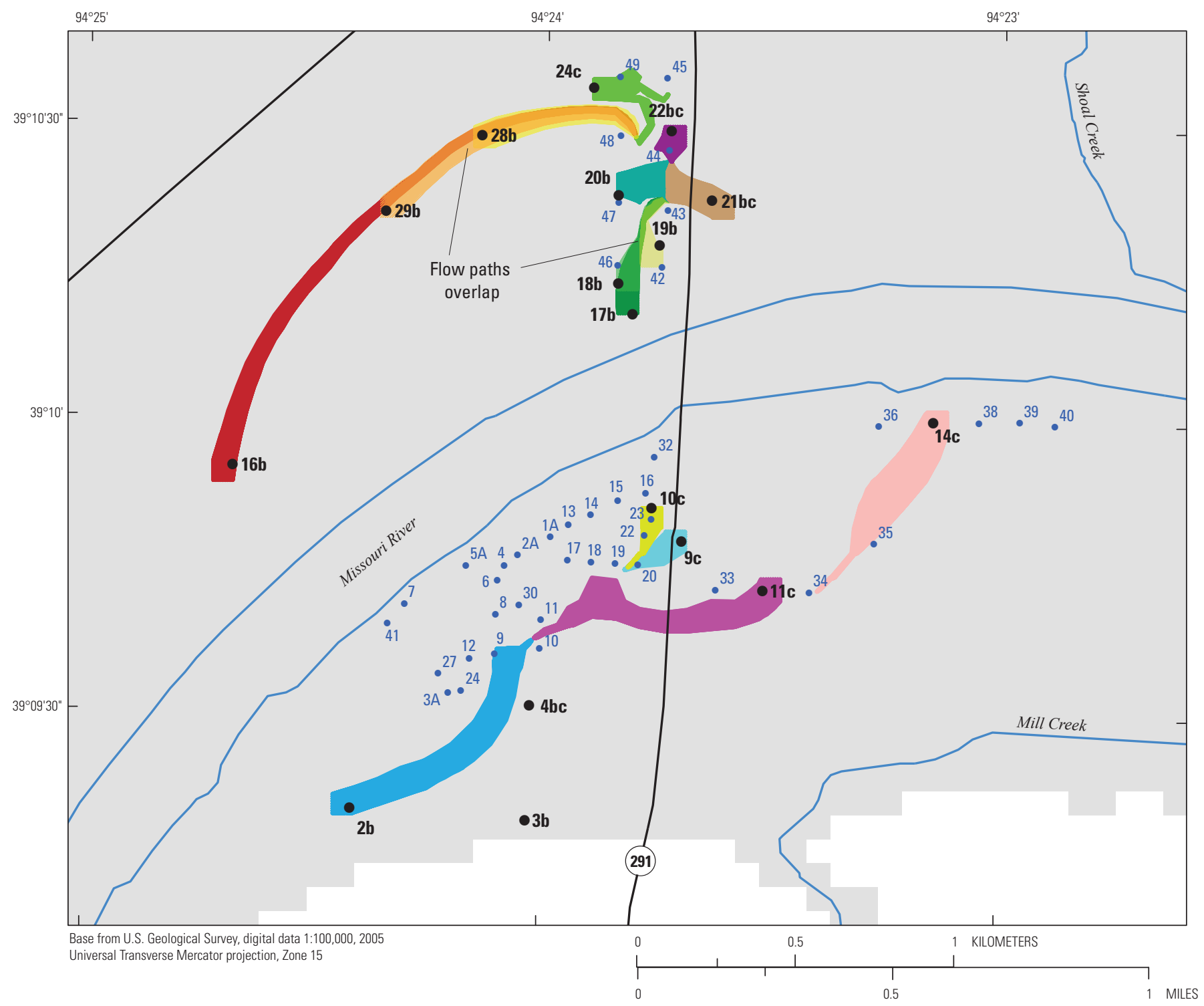

EXPLANATION

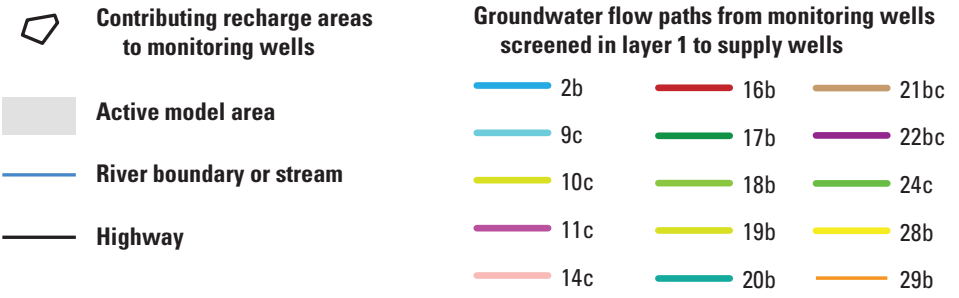

Figure 22. Groundwater flow paths from monitoring wells grouped by model layer to supply wells of the Independence well field. 


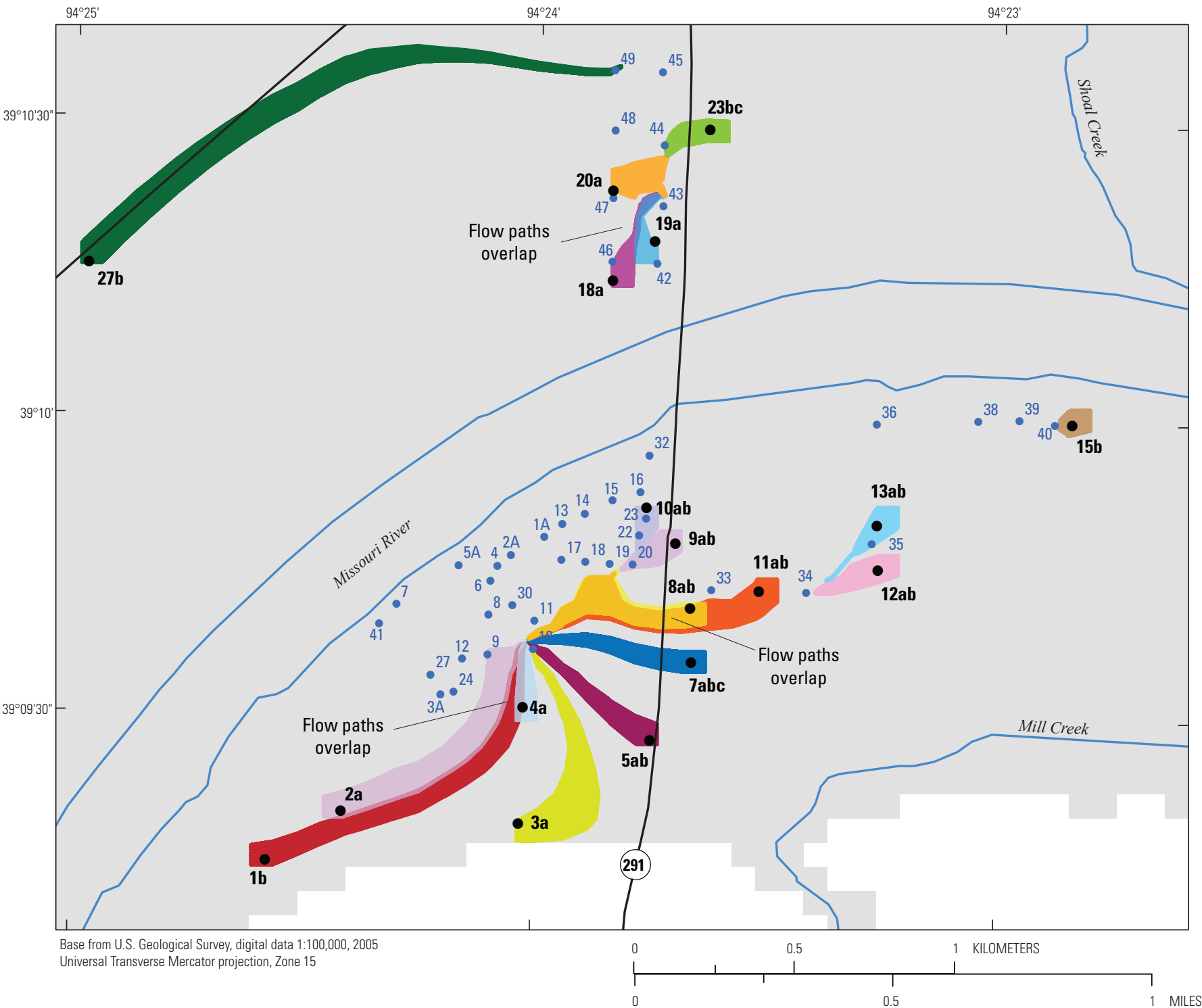

EXPLANATION

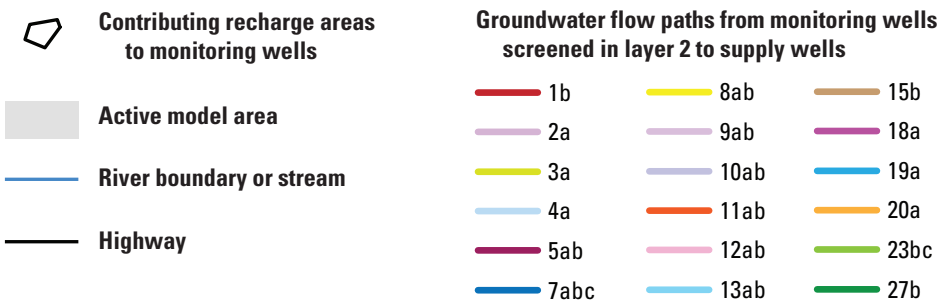

Figure 22. Groundwater flow paths from monitoring wells grouped by model layer to supply wells of the Independence well field.-Continued 


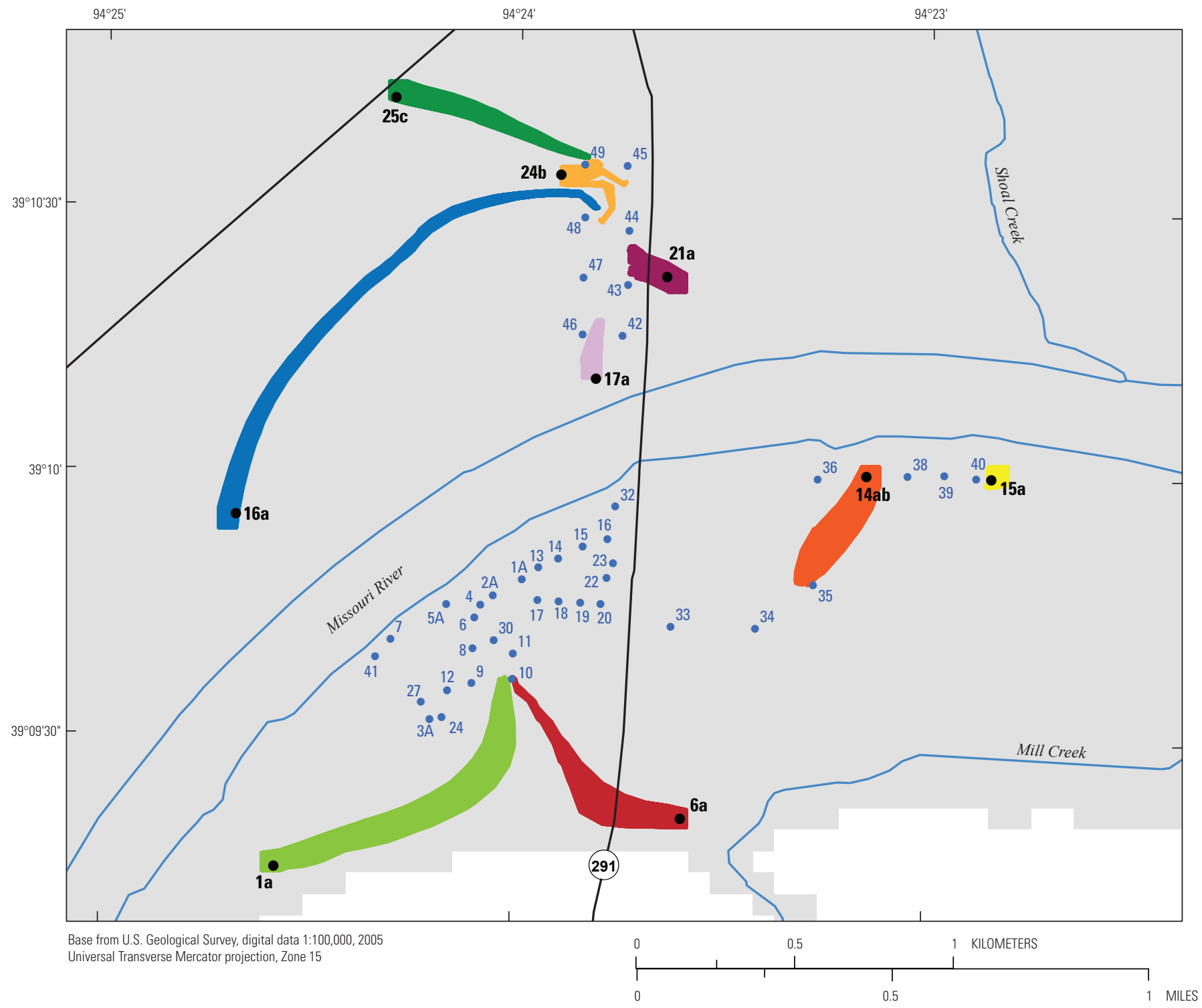

\section{EXPLANATION} $\nabla \begin{gathered}\text { Contributing recharge areas } \\ \text { to monitoring wells }\end{gathered}$

Active model area

River boundary or stream

Highway
Groundwater flow paths from monitoring wells screened in layer 3 to supply wells

$\begin{array}{crr}1 \mathrm{a} & 15 \mathrm{a} & -21 \mathrm{a} \\ 6 \mathrm{a} & 16 \mathrm{a} & 24 \mathrm{~b} \\ 14 \mathrm{ab} & 17 \mathrm{a} & 25 \mathrm{c}\end{array}$ 3b Monitoring well and identifier (table 14)

- 40 Supply well and identifier

Figure 22. Groundwater flow paths from monitoring wells grouped by model layer to supply wells of the Independence well field.-Continued 


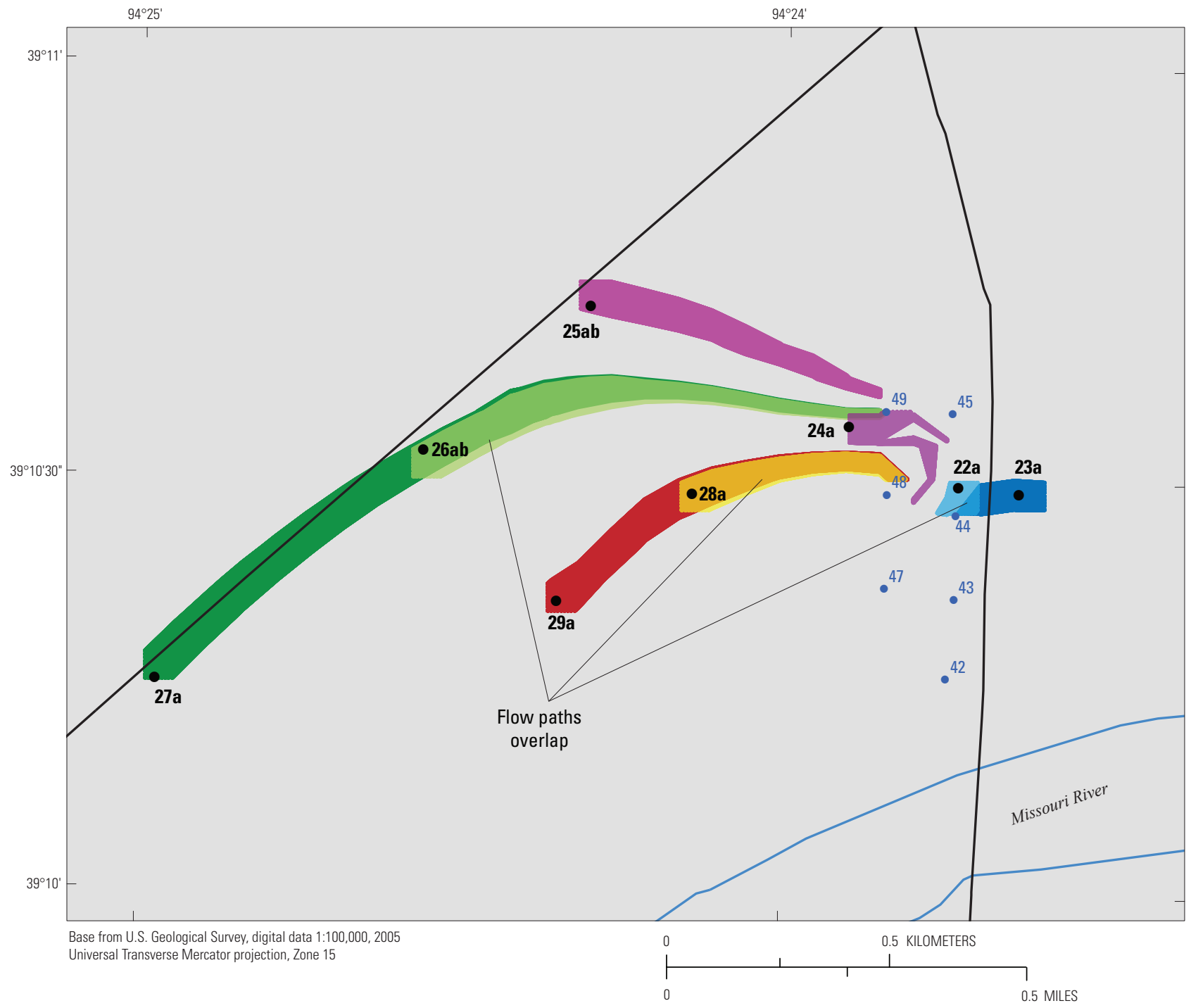

EXPLANATION

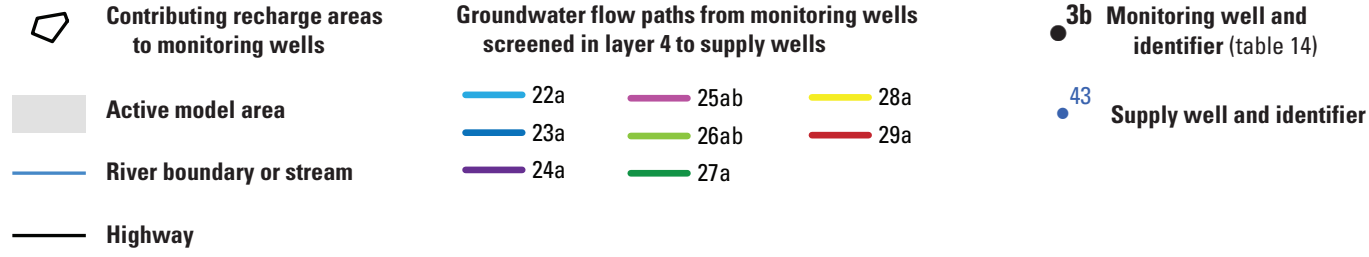

Figure 22. Groundwater flow paths from monitoring wells grouped by model layer to supply wells of the Independence well field.-Continued 
Table 16. Monitoring well, percentage of particles to each supply well, and groundwater travel times from monitoring wells to each supply well.

[a,b,c in identifier indicates relative depth of the well in each nest from "a" the deepest to "c" the shallowest. For well nest 4, 4a is deepest, 4c is intermediate, and $4 \mathrm{~b}$ is shallowest; Min, minimum; Avg, average; Max, maximum; -, not applicable]

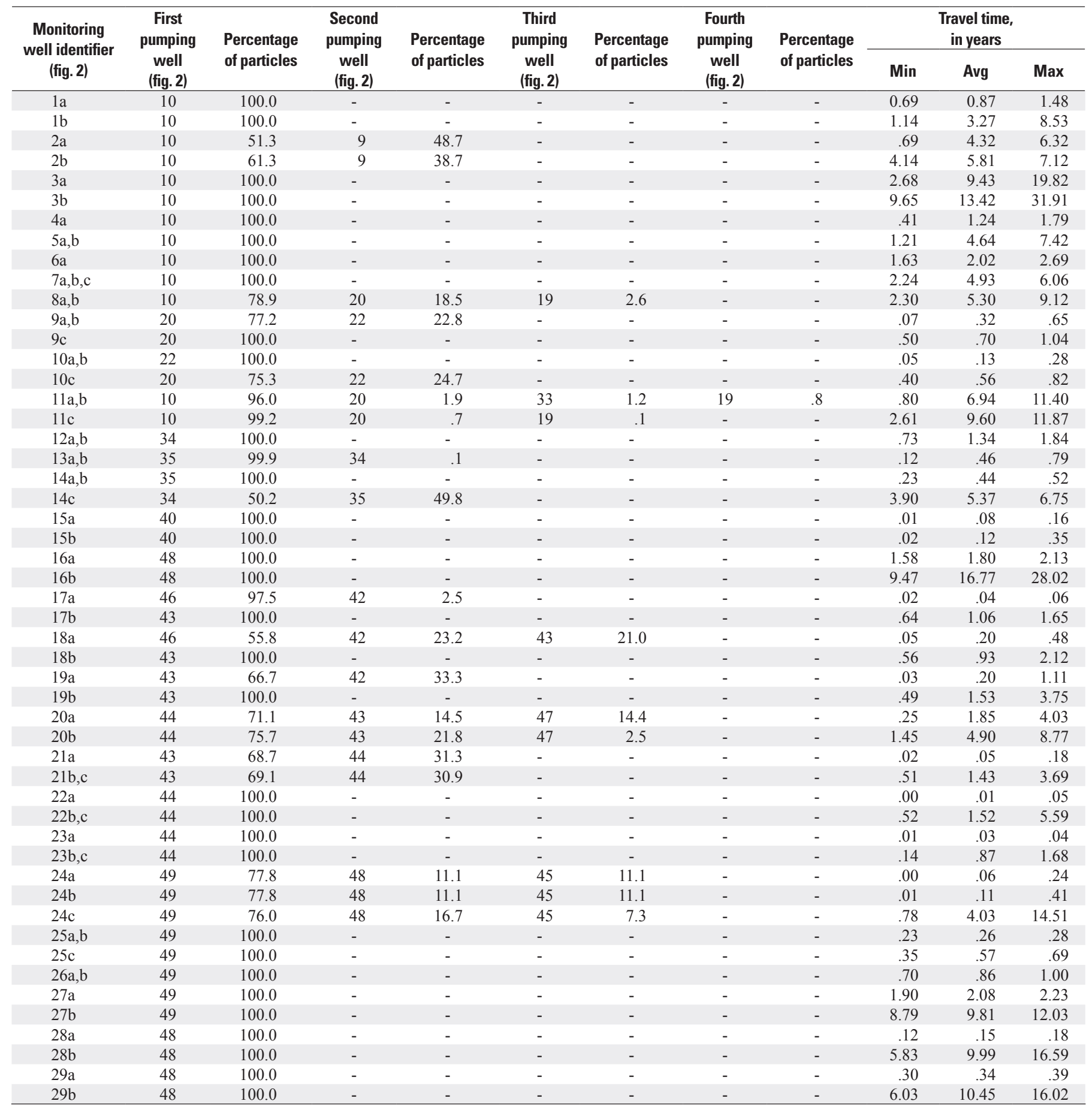


upgradient in the regional flow field will intercept groundwater moving downgradient. This causes the CRA of the downgradient wells to expand to either side of the CRA of the upgradient well. The most notable effect of interference between supply wells is shown by the CRAs of supply wells north of the Missouri River (fig. 19). Wells 42 and 46 located near the Missouri River have small CRAs that extend to the river. Wells 43 and 47 located farther from the river have CRAs that extend to either side of the CRAs of wells 42 and 46 . Wells 45 and 49 have CRAs that extend to either side of the CRAs of wells 43 and 47. The individual CRAs of wells may dramatically change in shape and size if pumping changes in nearby wells. In a well field where wells pump intermittently, CRAs intermittently change in shape and size.

\section{Groundwater Quality}

Potential source areas of groundwater contamination near the Independence well field were compiled from publicly available geographic information system (GIS) data sources listed in table 17 (Missouri Resource Assessment Program, 2005, Missouri Department of Natural Resources, 2007a, 2008a, b, c, 2009a, b, c) and an onsite survey of the area near the Independence well field to provide information pertinent to the quality of the well-field source water and future wellfield management decisions (fig. 23). Although some areas have documented groundwater contamination, identification as a potential source area of groundwater contamination does not imply that the area is contaminating or will contaminate groundwater in the Missouri River alluvial aquifer.

Potential point source areas of contamination near the Independence well field include above- and below-ground storage tanks; hazardous waste generators including a closed oil refinery and industrial areas; mining activities; National
Pollution Discharge Elimination System (NPDES) outfalls and stormwater discharge; Superfund sites; chemical spills adjacent to the well field along State Highway 291, along State Highway 210, and along the rail lines; chemical- or petroleum-product spills in the Missouri River; spills or runoff into Mill Creek from landfills; leaching of contaminants into groundwater from landfills in upland areas and then into the alluvial aquifer; and runoff from limestone mining operations south of the well field. Potential nonpoint source areas of contamination have larger areal extent and distribution and include infiltration of wastewater treatment land-application of municipal sewage sludge on the north side of the Missouri River west of the well field and fertilizers and pesticides used on crops and on highway right-of-ways. Specific information for areas of potential contamination shown in figure 23 is listed in table 18.

\section{Dissolved Oxygen and Physical Properties}

Median dissolved oxygen was $0.1 \mathrm{mg} / \mathrm{L}$ (milligram per liter) in 503 well samples, and concentrations ranged from $<0.1$ to $7.70 \mathrm{mg} / \mathrm{L}$; median $\mathrm{pH}$ was 6.9 in 561 samples, and values ranged from 6.2 to 7.8 ; median specific conductance was $929 \mu \mathrm{S} / \mathrm{cm}$ (microsiemens per centimeter at 25 degrees Celsius) in 560 samples, and values ranged from 232 to $1,700 \mu \mathrm{S} / \mathrm{cm}$; and median water temperature was $16.1{ }^{\circ} \mathrm{C}$ (degrees Celsius) in 570 samples, and temperature ranged from 5.8 to $28.8^{\circ} \mathrm{C}$. Maximum, median, minimum and quartiles of dissolved oxygen, $\mathrm{pH}$, specific conductance, and water temperature in samples from each monitoring well are shown in figure 24.

Dissolved oxygen, $\mathrm{pH}$, specific conductance, and temperature in groundwater and the linear trend of median values for samples from monitoring wells grouped by depth interval are shown in figure 25 . The linear trend with depth interval

Table 17. Geographic information system data sources for potential groundwater contamination near the Independence well field.

[MODNR, Missouri Department of Natural Resources; ESRI, Environmental Systems Research Institute; NPDES, National Pollution Discharge Elimination System; MORAP, Missouri Resource Assessment Partnership]

\begin{tabular}{|c|c|c|c|c|}
\hline Source type & Publisher & $\begin{array}{c}\text { Publication } \\
\text { date }\end{array}$ & File type & Geographic information system data source \\
\hline Above ground storage tank & MODNR & 24-Aug-07 & ESRI shapefile & ftp://msdis.missouri.edu/pub/state/st_abv_grd_tanks.zip \\
\hline Hazardous waste generators & MODNR & 30-Jun-08 & ESRI shapefile & ftp://msdis.missouri.edu/pub/state/st_haz_generator.zip \\
\hline Mining & MODNR & $15-O c t-08$ & ESRI shapefile & ftp://msdis.missouri.edu/pub/state/st_ind_min_mines.zip \\
\hline NPDES stormwater discharge & MODNR & 20-Apr-09 & ESRI shapefile & ftp://msdis.missouri.edu/pub/state/st_npdes_storm.zip \\
\hline Superfund site & MODNR & 1-Jun-09 & ESRI shapefile & ftp://msdis.missouri.edu/pub/state/st_superfund.zip \\
\hline Land cover & MORAP & 22-Aug-05 & ESRI raster digital data & $\begin{array}{l}\text { http://msdis.missouri.edu/pub/lulc/lulc05/clay_lulc05.e00.gz } \\
\text { http://msdis.missouri.edu/pub/lulc/lulc05/jacks_lulc05.e00.gz }\end{array}$ \\
\hline
\end{tabular}




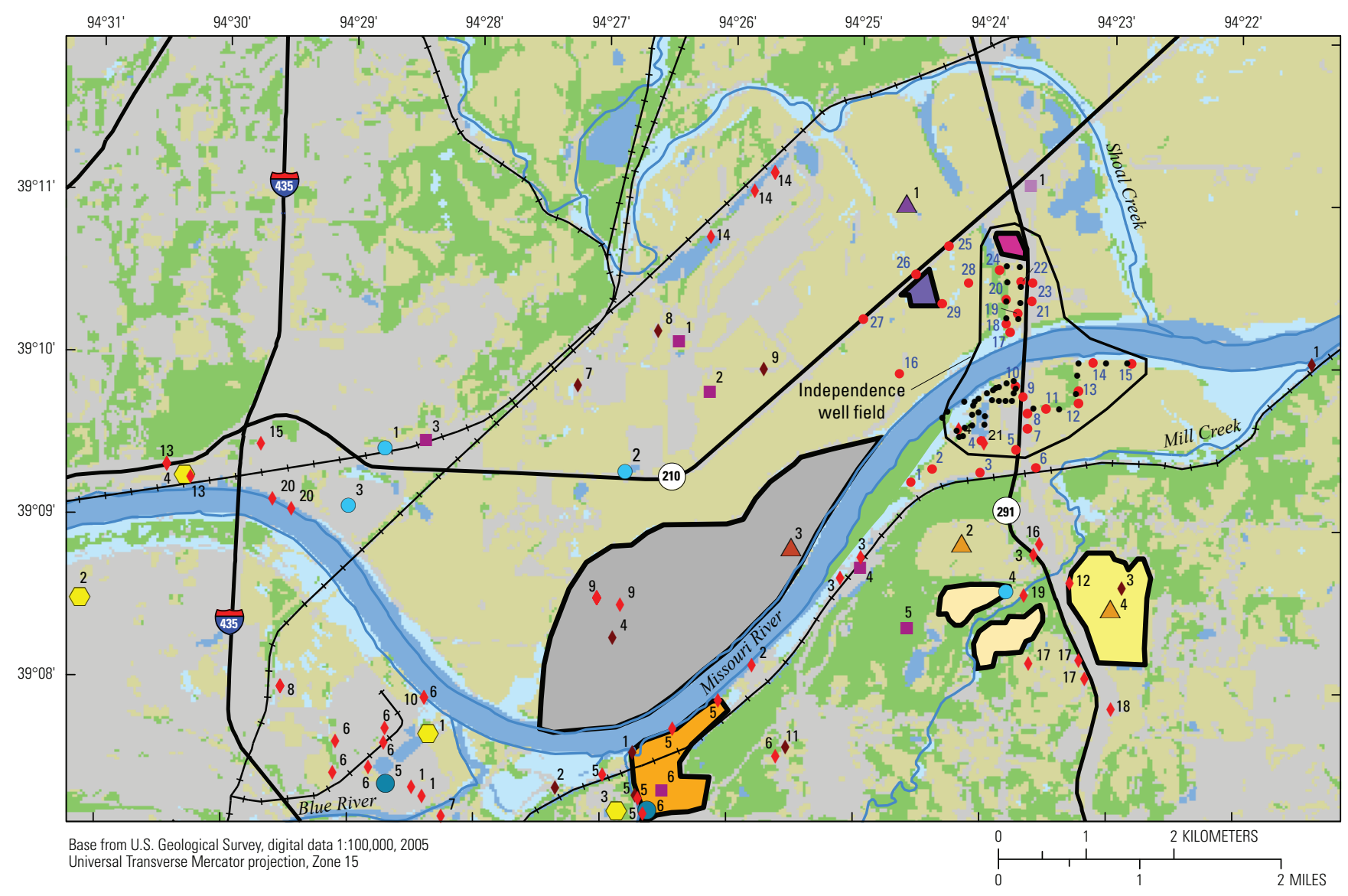

EXPLANATION

Potential contamination source areas

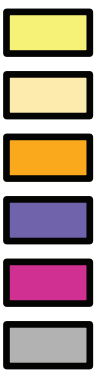

Active landfill

Closed landfil

Closed oil refinery

Construction landfill

Temporary asphalt plant

Wastewater treatment land application
Land cover

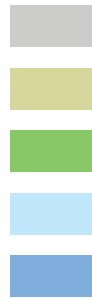

+ Railroad

— Highway

_ River boundary or stream

Wetland

Open water
- Supply well

Urban/impervious

Agriculture/grassland

Forest/woodland

16. Monitoring well and identifier

Potential contamination sources

- Above ground storage tank

- Below ground storage tank

- Hazardous waste generator - large quantity

- Hazardous waste generator - small quantity

$\triangle$ Limestone mining

$\triangle$ Sand mining

$\triangle$ Sand and gravel mining

- National Pollution Discharge Elimination System

- National Pollution Discharge Elimination System storm water discharge points

$\square$ Superfund site

Map identification numbers are shown in black next to each potential contamination source symbol are specific for each type of potential contamination and are

listed in table 18 to provide additional information and sources of data for each area indicated. Well identifiers are shown in blue next to each monitoring well.

Figure 23. Locations of potential source areas of groundwater contamination near the Independence well field. 
Table 18. Information for potential sources of potential groundwater contamination near the Independence well field.

[MOAG, Missouri Department of Agriculture; ID, Identification number; MODNR, Missouri Department of Natural Resources; EPA, U.S. Envirmonmental Protection Agency; LR, Missouri Land Reclamation; TN, tracking number; NPDES, National Pollution Discharge Elimination System; VOC, volatile organic compound; BTEX, benzene, toluene, ethylbenzene, xylene]

\begin{tabular}{|c|c|c|c|c|c|c|c|}
\hline \multicolumn{8}{|c|}{${ }^{\text {a} A b o v e ~ g r o u n d ~ s t o r a g e ~ t a n k ~}$} \\
\hline $\begin{array}{l}\text { Map ID } \\
\text { (fig. 22) }\end{array}$ & Name & Address of owner & City & \multicolumn{3}{|c|}{ MOAG ID } & Status \\
\hline 1 & Sales Conoco & 4500 North Cobbler & Independence & \multicolumn{3}{|c|}{2331} & Open \\
\hline \multicolumn{8}{|c|}{${ }^{b} B e l o w$ ground storage tank } \\
\hline $\begin{array}{l}\text { Map ID } \\
\text { (fig. 22) }\end{array}$ & Name & Address of owner & City & \multicolumn{2}{|c|}{ MODNR ID } & \multicolumn{2}{|r|}{ Remediation } \\
\hline 1 & Transport Corporation of America & 4100 Northeast Kimball Drive & Kansas City & \multicolumn{2}{|c|}{ ST0020650 } & \multirow{6}{*}{\multicolumn{2}{|c|}{ Active remediation site }} \\
\hline 2 & Federal Express Ground & 12501 Northeast $40 \mathrm{TH}$ Street & Kansas City & \multirow{2}{*}{\multicolumn{2}{|c|}{$\begin{array}{l}\text { ST0021470 } \\
\text { ST0020819 }\end{array}$}} & & \\
\hline 3 & Highway 210 Travel Plaza & 8801 Northeast Birmingham Road & Kansas City & & & & \\
\hline 4 & LaFarge Corporation sugar Creek Plant & 4201 North River Road [PO Box 1071] & Sugar Creek & \multicolumn{2}{|c|}{$\begin{array}{l}\text { ST0020819 } \\
\text { ST0006654 }\end{array}$} & & \\
\hline 5 & TOTAL \#4391 & 211 South Noland Road & Independence & \multicolumn{2}{|c|}{ ST0013970 } & & \\
\hline 6 & BP Products North America, Inc. & 1000 North Sterling & Sugar Creek & \multicolumn{2}{|c|}{ ST0006650 } & & \\
\hline \multicolumn{8}{|c|}{${ }^{\circ}$ Hazardous waste generator } \\
\hline $\begin{array}{l}\text { Map ID } \\
\text { (fig. 22) }\end{array}$ & Name & Address of owner & City & \multicolumn{2}{|l|}{ EPA ID } & MODNR ID & Facility Status \\
\hline 1 & KC Envelope Co. Inc. & 8638 Northeast Underground Drive & Kansas City & \multicolumn{2}{|c|}{ MOD095831640 } & 3604 & Small quantity \\
\hline 2 & Grainger Inc. & 11200 East 210 Highway & North Kansas City & \multicolumn{2}{|c|}{ MOD981727118 } & 6630 & Small quantity \\
\hline 3 & Ameristar Casino Kansas City & 3200 North Ameristar Drive & Kansas City & \multicolumn{2}{|c|}{ MOR000012179 } & 32572 & Small quantity \\
\hline 4 & LaFarge North America, Inc. & 2200 North Courtney Road & Sugar Creek & \multicolumn{2}{|c|}{ MOR000506790 } & 42603 & Small quantity \\
\hline 5 & Bayer Cropscience & 8400 Hawthorne Road & Kansas City & \multicolumn{2}{|c|}{ MOD056389828 } & 1231 & Large quantity \\
\hline 6 & AMOCO Sugar Creek Former Refinery & 1000 North Sterling & Sugar Creek & \multicolumn{2}{|c|}{ MOD007161425 } & 1210 & Large quantity \\
\hline \multicolumn{8}{|c|}{ dMining } \\
\hline $\begin{array}{l}\text { Map ID } \\
\text { (fig. 22) }\end{array}$ & Name & Address of owner & City & LR Permit ID & LR TN & Status & Permit type \\
\hline 1 & Mid America Sand, LLC & 14800 M-210 Highway & Independence & 1023 & 2263 & Active & Open Pit 5,000 tons or more \\
\hline 2 & Lafarge North America, Inc. & 2200 Courtney Road & Sugar Creek & 90 & 865 & Active & Open Pit 5,000 tons or more \\
\hline 3 & Kansas City Sand \& Gravel, LLC & 643 Tennessee & Lawrence & 1018 & 2265 & Active & Instream 5,000 tons or more \\
\hline 4 & Woodmen of the World Life Insurance Society & $\begin{array}{l}\text { C/O LS Commercial Real Estate } 8301 \\
\text { West 125th Street Suite } 210\end{array}$ & Overland Park & $0570 \mathrm{~T}$ & 565 & Active & Open Pit 5,000 tons or more \\
\hline \multicolumn{8}{|c|}{ eNPDES } \\
\hline $\begin{array}{l}\text { Map ID } \\
\text { (fig. 22) }\end{array}$ & Name & Address of owner & City & $\begin{array}{l}\text { Missouri } \\
\text { NPDES ID }\end{array}$ & $\begin{aligned} \text { Total n } \\
\text { of ou }\end{aligned}$ & $\begin{array}{l}\text { umber } \\
\text { falls }\end{array}$ & Receiving stream \\
\hline 1 & Bayer Corporation Kansas City Plant & 8400 Hawthorne Road & Kansas City & MO0002526 & & 2 & Blue River \\
\hline 2 & LaFarge North America-Kansas City Terminal & 4201 Cement City, Road & Sugar Creek & MO0002585 & & 1 & Missouri River \\
\hline 3 & LaFarge North America-Sugar Creek & 2000 Courtney Road & Sugar Creek & MO0002666 & & 3 & Missouri River \\
\hline 4 & Independence, Courtney Bend Water Treatment Plant & Sugar Creek & Sugar Creek & MO0003646 & & 3 & Missouri River \\
\hline 5 & BP Products NA Inc. & 1000 North Sterling & Sugar Creek & MO0004774 & & 7 & Missouri River \\
\hline 6 & Kansas City Power and Light Hawthorne Station & 8700 Hawthorne Road & Kansas City & MO0004855 & & 9 & Missouri River \\
\hline 7 & AK Steel Corporation & 7000 Winner Road & Kansas City & MO0004952 & & & Blue River \\
\hline 8 & Kansas City Blue River Wastewater Treatment Facility & 7300 Hawthorne Road & Kansas City & MO0024911 & & 5 & Missouri River \\
\hline 9 & Birmingham Wastewater Treatment Facility & 10801 NE 28TH Street & Kansas City & MO0049531 & & & Missouri River \\
\hline
\end{tabular}


Table 18. Information for potential sources of potential groundwater contamination near the Independence well field. - Continued

[MOAG, Missouri Department of Agriculture; ID, Identification number; MODNR, Missouri Department of Natural Resources; EPA, U.S. Envirmonmental Protection Agency; LR, Missouri Land Reclamation; TN, tracking number; NPDES, National Pollution Discharge Elimination System; VOC, volatile organic compound; BTEX, benzene, toluene, ethylbenzene, xylene]

\begin{tabular}{|c|c|c|c|c|c|c|}
\hline \multicolumn{7}{|c|}{ eNPDES } \\
\hline $\begin{array}{l}\text { Map ID } \\
\text { (fig. 22) }\end{array}$ & Name & Address of owner & City & $\begin{array}{c}\text { Missouri } \\
\text { NPDES ID }\end{array}$ & $\begin{array}{l}\text { Total number } \\
\text { of outfalls }\end{array}$ & Receiving stream \\
\hline 10 & Conservation Chemical Co. Site & 8900 Front Street & Kansas City & MO0108472 & 1 & Missouri River \\
\hline 11 & KCSRC, ONE SPOT REPAIR & 4747 Front Street & Kansas City & MO0115703 & 1 & Tributary Missouri River \\
\hline 12 & Courtney Ridge Recycling & 2001 N. M-291 Highway & Sugar Creek & MO0117790 & 1 & Mill Creek \\
\hline 13 & Brenntag-Mid South Inc. & 6301 Northeast Birmingham Road & Kansas City & MO0121771 & 5 & Missouri River \\
\hline 14 & NSRC/Voltz Intermodel / KC & 4800 North Kimball Drive & Birmingham & MO0123102 & 7 & Unnamed tributary Shoal Creek \\
\hline 15 & Hunt Martin Materials, LLC & 410 Randolph Road & Kansas City & MOG490178 & 1 & Tributary Missouri River \\
\hline 16 & LaFarge North America-Sugar Creek & 2601 North State Route 291 Highway & Sugar Creek & MOG490333 & 1 & Tributary Mill Creek \\
\hline 17 & Carefree Industrial Park & 1600 North M-291 Highway & Independence & MOG490585 & 3 & Tributary Mill Creek \\
\hline 18 & LaFarge-Independence Quarry & 16400 East Kentucky Road & Independence & MOG490759 & 1 & Tributary Mill Creek \\
\hline 19 & APAC-Kansas Inc. Kansas City & 2031 North Courtney Road & Sugar Creek & MOG491073 & 1 & Tributary Mill Creek \\
\hline 20 & Holliday Sand And Gravel Co. & 7801 Northeast Birmingham & Avondale & MOG500028 & 2 & Missouri River \\
\hline 21 & Courtney Bend Water Treatment Pland & 3008 North Cement City Road & Sugar Creek & MOG640177 & 1 & Missouri River \\
\hline
\end{tabular}

\begin{tabular}{|c|c|c|c|c|c|c|}
\hline \multicolumn{7}{|c|}{ 'NPDES Stormwater } \\
\hline $\begin{array}{l}\text { Map ID } \\
\text { (fig. 22) }\end{array}$ & Name & Address of owner & City & $\begin{array}{c}\text { Missouri } \\
\text { NPDES ID }\end{array}$ & $\begin{array}{c}\text { Total number } \\
\text { of outfalls }\end{array}$ & Receiving stream \\
\hline 1 & City of Sugar Creek & 103 South Sterling & Sugar Creek & MOR040031 & 2 & Missouri River \\
\hline 2 & BP Products North America & Sugar Creek Marketing & Sugar Creek & MOR107924 & 1 & Unnamed tributary Sugar Creek \\
\hline 3 & Courtney Ridge Landfill & 2001 North M-291 Highway & Sugar Creek & MOR10A263 & 1 & Tributary Mill Creek \\
\hline 4 & Auburndale Estates & Northeast Cookingham Drive & Kansas City & MOR10A694 & 1 & Tributary Fishing River \\
\hline 5 & BP Products North America & Sugar Creek Marketing Terrace & Sugar Creek & MOR10B266 & 1 & Tributary Sugar Creek \\
\hline 6 & Siemens Westinghouse & 4140 Front Street & Kansas City & MOR203269 & 1 & Tributary Missouri River \\
\hline 7 & Birmingham Auto Parts & 600 Spratley & Birmingham & MOR60A005 & 1 & Tributary Mill Creek \\
\hline 8 & Transport Corp of America & 4100 North Kimball Drive & Kansas City & MOR80C355 & 1 & Tributary Missouri River \\
\hline 9 & FEDEX Ground & 12501 Northease $40 \mathrm{TH}$ Street & Kansas City & MOR80C475 & 1 & Tributary Missouri River \\
\hline
\end{tabular}

\begin{tabular}{|c|c|c|c|c|c|c|c|}
\hline \multicolumn{8}{|c|}{${ }^{9}$ Superfund } \\
\hline $\begin{array}{l}\text { Map ID } \\
\text { (fig. 22) }\end{array}$ & Name & Address of owner & City & EPA ID & $\begin{array}{l}\text { MODNR } \\
\text { ID }\end{array}$ & $\begin{array}{c}\text { National } \\
\text { Priorities } \\
\text { List }\end{array}$ & Known Contaminants \\
\hline 1 & Conservation Chemical Company & 8900 Front Street & Kansas City & MOD000829705 & 10180 & YES & $\begin{array}{l}\text { Acids/bases, arsenic, cadmium, cyanides, dioxin, inorganic } \\
\text { compounds, metals, organic compounds, phenols, VOCs }\end{array}$ \\
\hline 2 & HCI Chemtech-Stillwell Street & 5200 Stillwell Street & Kansas City & MOSFN0703588 & 10533 & NO & BTEX, solvents \\
\hline 3 & Amoco Oil Co & 1000 North Sterling & Sugar Creek & MOD007161425 & 10044 & $\mathrm{NO}$ & Arsenic, BTEX, cadmium \\
\hline 4 & HCI Chemtech - Birmingham Road & 6301 Northeast Birmingham Road & North Kansas City & MOD980633143 & 10142 & NO & Acids/bases, pesticides, semi-volatiles, solvents \\
\hline
\end{tabular}

a Missouri Department of Natural Resources, 2007a

${ }^{\mathrm{b}}$ Missouri Department of Natural Resources, 2008a.

${ }^{c}$ Missouri Department of Natural Resources, 2008b.

${ }^{\mathrm{d}}$ Missouri Department of Natural Resources, 2008c.

e Missouri Department of Natural Resources, 2009a.

${ }^{\mathrm{f}}$ Missouri Department of Natural Resources, 2009b.

g Missouri Department of Natural Resources, 2009c. 

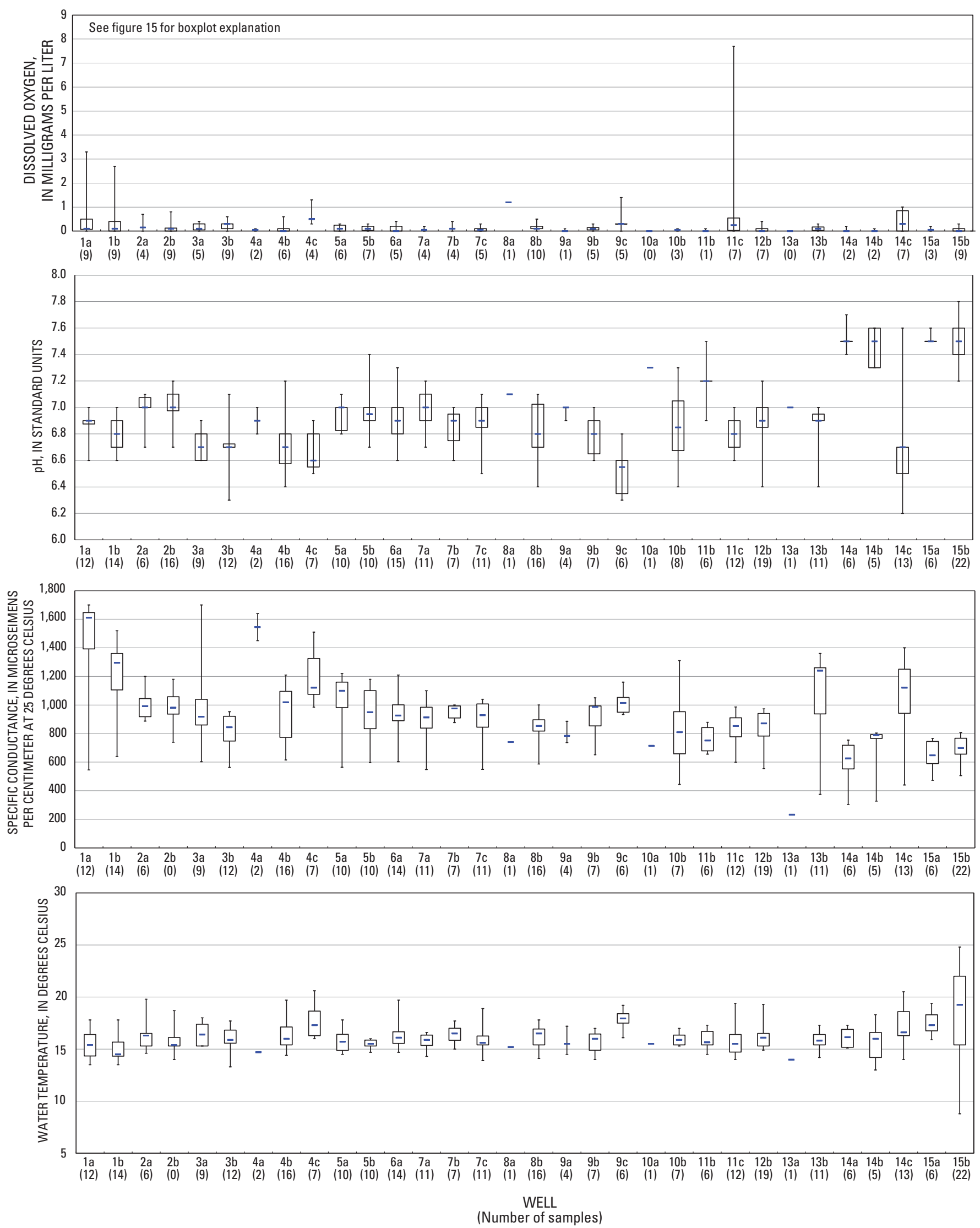

Figure 24. Boxplots of dissolved oxygen, pH, specific conductance, and temperature for water samples from each monitoring well. 

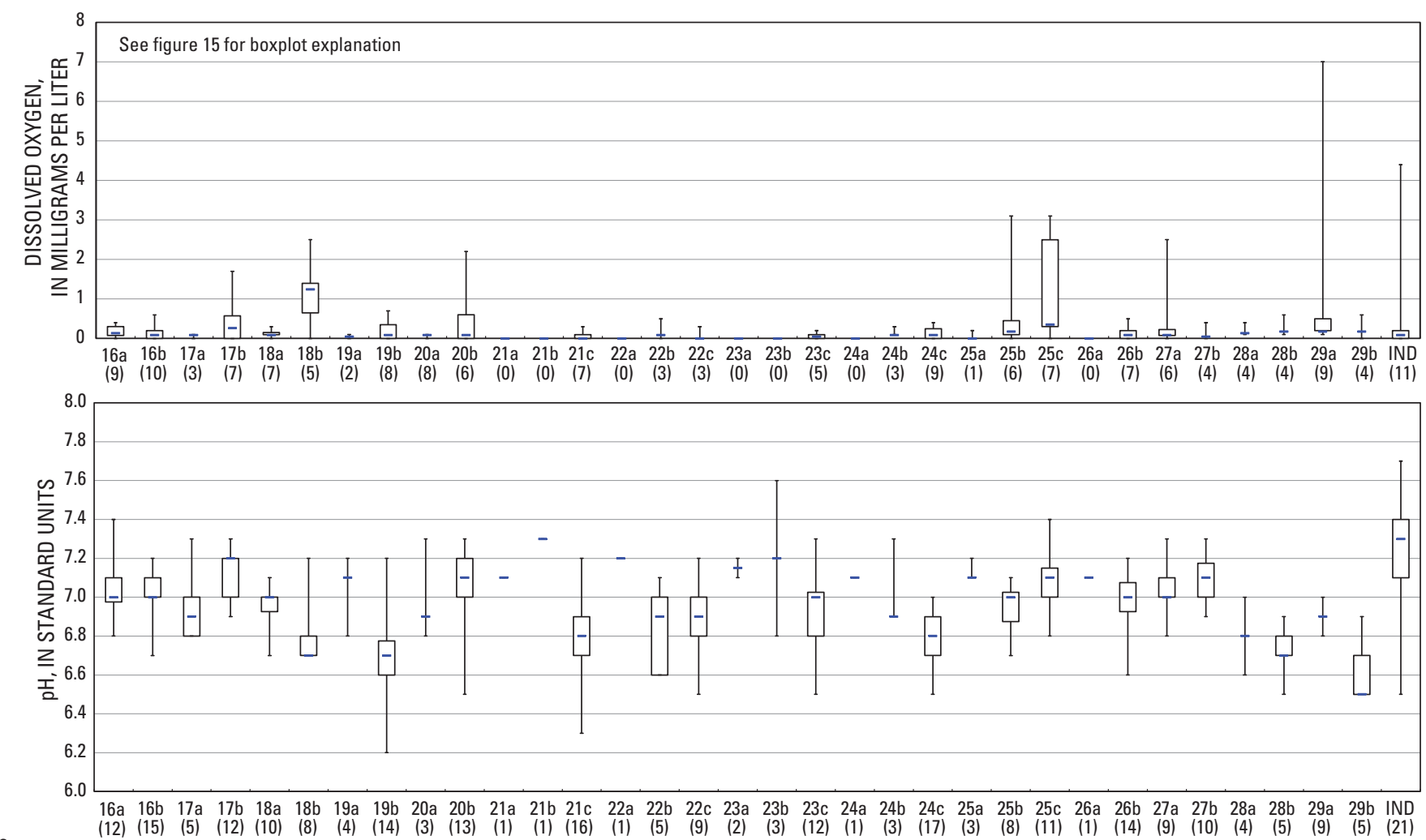

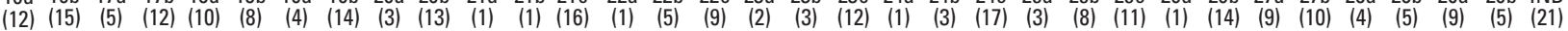
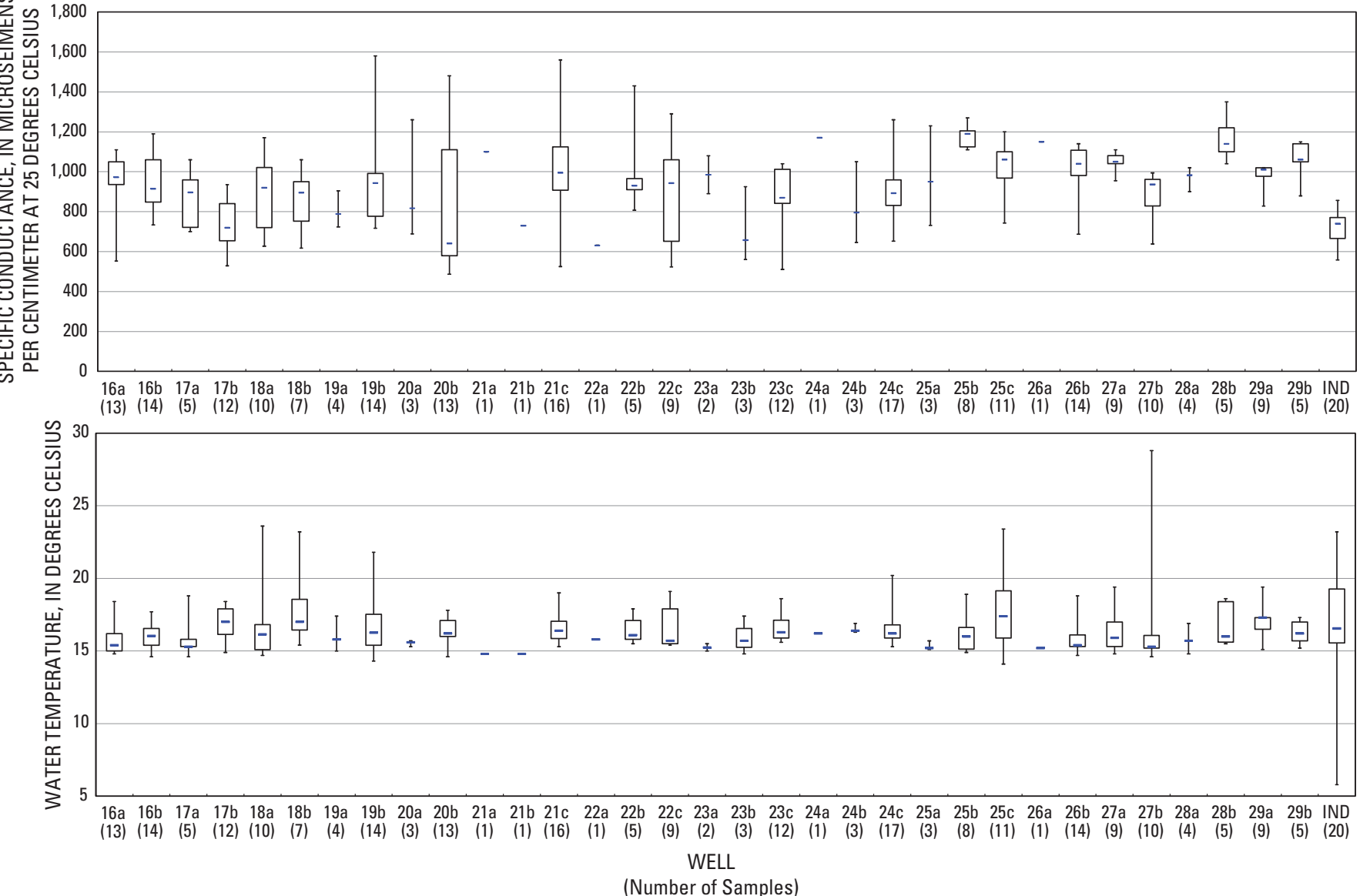

Figure 24. Boxplots of dissolved oxygen, $\mathrm{pH}$, specific conductance, and temperature for water samples from each monitoring well.-Continued 

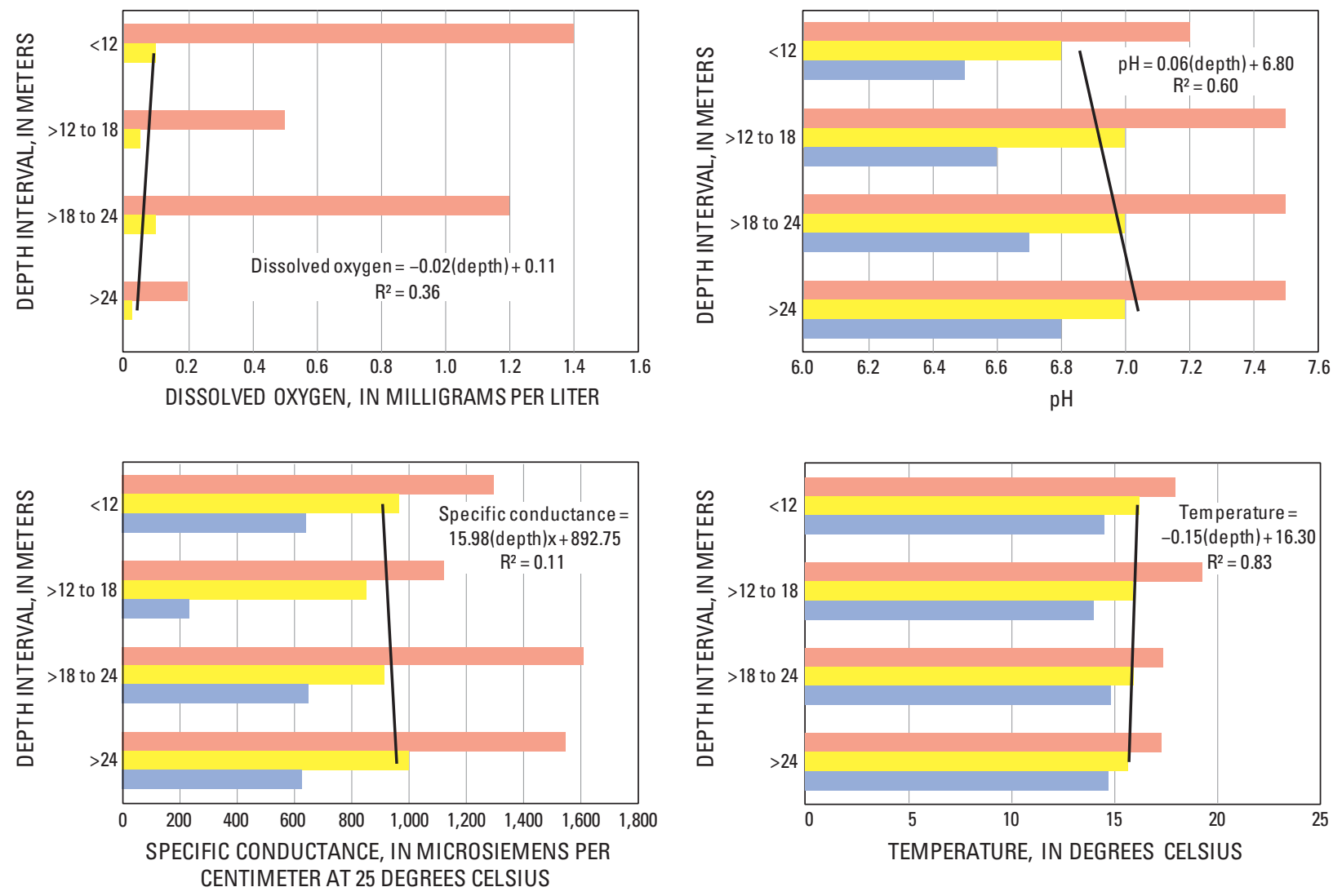

EXPLANATION

$[<$, less than; $>$, greater than $]$

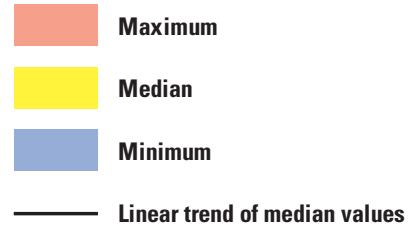

Figure 25. Dissolved oxygen, $\mathrm{pH}$, specific conductance, and temperature and linear trend of median values for water samples from monitoring wells grouped by depth interval. 
of median concentrations of dissolved oxygen decreased $0.02 \mathrm{mg} / \mathrm{L}\left(\mathrm{R}^{2}=0.36\right)$, of $\mathrm{pH}$ increased 0.06 unit $\left(\mathrm{R}^{2}=0.60\right)$, of specific conductance increased $15.98 \mu \mathrm{S} / \mathrm{cm}$ per depth interval $\left(\mathrm{R}^{2}=0.11\right)$, and of temperature decreased $0.15^{\circ} \mathrm{C}$ per depth interval $\left(\mathrm{R}^{2}=0.83\right)$. Sixty percent of the increase of $\mathrm{pH}$ was related to increased depth interval. Specific conductance had a slight correlation of its variability to depth interval, and 83 percent of the temperature difference in samples from monitoring wells was related to depth interval. The largest maximum and median concentrations for dissolved oxygen are in the $<12-\mathrm{m}$ and 18- to 24-m depth intervals. Values for $\mathrm{pH}$ are smallest in the $<12-\mathrm{m}$ depth interval and the minimum value increases with depth. Maximum, median, and minimum values for specific conductance are smallest for the 12- to 18 -m depth interval. The 18- to 24-m depth interval had the largest maximum and minimum, but the $>24-\mathrm{m}$ depth interval had the largest median value.

Highest median $\mathrm{pH}$ values south of the Missouri River are from samples from monitoring wells $15 \mathrm{~b}$ (12- to $18-\mathrm{m}$ ); 14b and 15a, (18- to 24-m); and 14a (> 24-m). Highest median $\mathrm{pH}$ values north of the Missouri River are from samples from monitoring well 21b (18- to 24-m) (fig. 26). Smallest median $\mathrm{pH}$ values south of the Missouri River are from samples from monitoring wells $9 \mathrm{c}(<12-\mathrm{m})$; $3 \mathrm{~b}, 4 \mathrm{~b}$, and $4 \mathrm{c}(12-$ to $18-\mathrm{m})$; and $3 \mathrm{a}$ and $7 \mathrm{~b}$ (18- to $24-\mathrm{m})$. Smallest median $\mathrm{pH}$ values north of the Missouri River were from samples from monitoring wells 20a (12- to $18-\mathrm{m}) ; 25 \mathrm{c}$ (18- to 24-m); and 24b and $28 \mathrm{~b}(>24-\mathrm{m})$. Largest median specific conductance values (fig. 27) were from samples from monitoring wells $1 \mathrm{~b}$ and $13 \mathrm{~b}$ (<12-m), 1a (18- to 24-m), and 4a (> 24-m) located south of the Missouri River. North of the Missouri River the largest median values of specific conductance were in samples from monitoring wells from the $>24-\mathrm{m}$ depth interval.

Boxplots and linear trend of median $\mathrm{pH}$ and median specific conductance for samples from wells grouped by year are shown in figure 28. The linear trend of median values of $\mathrm{pH}$ decreased 0.03 unit per year $\left(\mathrm{R}^{2}=0.48\right)$, and of specific conductance increased $19.97 \mu \mathrm{S} / \mathrm{cm}$ per year $\left(\mathrm{R}^{2}=0.45\right)$ from 1998 to 2008. For both specific conductance and $\mathrm{pH}$, the correlation coefficient is less than 0.5 which indicates less than one-half of the variation in median values is related to time.

\section{Nutrients}

Dissolved ammonia was detected in 475 of 504 samples (94 percent). Median dissolved ammonia was $0.54 \mathrm{mg} / \mathrm{L}$ as nitrogen $(\mathrm{N})$, and concentrations ranged from 0.02 (the laboratory reporting level) to $5.0 \mathrm{mg} / \mathrm{L}$ as $\mathrm{N}$. Dissolved nitrate plus nitrite was detected in samples from 107 of 560 samples (19 percent). Median dissolved nitrate plus nitrite was $0.06 \mathrm{mg} / \mathrm{L}$ as $\mathrm{N}$, and concentrations ranged from 0.02 to $7.0 \mathrm{mg} / \mathrm{L}$ as N. Dissolved nitrite was detected in 183 of 504 samples (36 percent). Median dissolved nitrite was 0.008 (the laboratory reporting level) $\mathrm{mg} / \mathrm{L}$ as $\mathrm{N}$, and concentrations ranged from 0.001 (estimated) to $0.09 \mathrm{mg} / \mathrm{L}$ as N.
Dissolved nitrate was detected in 64 of 560 samples (11 percent). Median dissolved nitrate was $0.38 \mathrm{mg} / \mathrm{L}$ as $\mathrm{N}$, and concentrations ranged from 0.02 to $6.6 \mathrm{mg} / \mathrm{L}$ as $\mathrm{N}$. Total inorganic nitrogen, the sum of ammonia as $\mathrm{N}$, nitrite as $\mathrm{N}$, and nitrate as $\mathrm{N}$, was calculated for 504 samples. Median total inorganic nitrogen was $0.68 \mathrm{mg} / \mathrm{L}$, and concentrations ranged from 0.07 to $7.0 \mathrm{mg} / \mathrm{L}$. Dissolved orthophosphate was detected in 357 of 504 samples (71 percent). Median dissolved orthophosphate was $0.02 \mathrm{mg} / \mathrm{L}$ as phosphorous $(\mathrm{P})$, and concentrations ranged from $<0.018$ to $1.31 \mathrm{mg} / \mathrm{L}$ as $\mathrm{P}$. Boxplots of ammonia, nitrite, nitrate, nitrite plus nitrate, orthophosphate, and total inorganic nitrogen are shown in figure 29 for all samples from monitoring wells.

Boxplots of total inorganic nitrogen and orthophosphate for samples from individual monitoring wells are shown in figure 30. The largest maximum total inorganic nitrogen concentration, $7.0 \mathrm{mg} / \mathrm{L}$, was from a sample from monitoring well $4 \mathrm{c}$. The largest median total inorganic nitrogen concentration, $4.3 \mathrm{mg} / \mathrm{L}$, was from samples from monitoring well $17 \mathrm{~b}$. The smallest median total inorganic nitrogen concentration, $0.12 \mathrm{mg} / \mathrm{L}$, was from samples from monitoring well $15 \mathrm{~b}$. The largest range of total inorganic nitrogen, 0.15 to $6.5 \mathrm{mg} / \mathrm{L}$, was in samples from monitoring well 24c. The largest maximum orthophosphate concentration, $1.3 \mathrm{mg} / \mathrm{L}$ as $\mathrm{P}$, was from a sample from monitoring well 13b. The largest median orthophosphate concentration, $0.32 \mathrm{mg} / \mathrm{L}$ as $\mathrm{P}$, was from a sample from monitoring well 20a. Samples from multiple wells had P concentrations less than the LRL for orthophosphate, $0.018 \mathrm{mg} / \mathrm{L}$ as $\mathrm{P}$.

Total inorganic nitrogen and orthophosphate in groundwater and linear trend of median concentrations for samples from monitoring wells grouped by depth are shown in figure 31. Median concentrations of total inorganic nitrogen increased $0.05 \mathrm{mg} / \mathrm{L}$ per depth interval $\left(\mathrm{R}^{2}=0.57\right)$, and median concentrations of orthophosphate were unrelated to depth interval $\left(R^{2}=0.07\right)$. Fifty-seven percent of the variation in total inorganic nitrogen was related to depth interval. Maximum concentrations for both total inorganic nitrogen and orthophosphate were largest in the shallower depth intervals and may indicate land-surface management practices were the sources of these constituents to groundwater. Median and minimum concentrations of total inorganic nitrogen increased slightly with depth, and median and minimum concentrations of orthophosphate were similar for all depth intervals.

The areal distribution of total inorganic nitrogen in groundwater for samples from monitoring wells grouped by depth interval is shown in figure 32. Samples from monitoring wells with median concentrations of total inorganic nitrogen greater than $2 \mathrm{mg} / \mathrm{L}$ include samples from monitoring wells $1 \mathrm{~b}, 13 \mathrm{~b}$, and $17 \mathrm{~b}(<12-\mathrm{m})$; well $2 \mathrm{~b}(12-$ to $18-\mathrm{m})$; and well 1a (18- to 24-m). No samples from monitoring wells screened $>24-\mathrm{m}$ had median concentrations above $2 \mathrm{mg} / \mathrm{L}$. With the exception of well $17 \mathrm{~b}$, all samples from monitoring wells with total inorganic nitrogen greater than $2 \mathrm{mg} / \mathrm{L}$ are south of the Missouri River. 

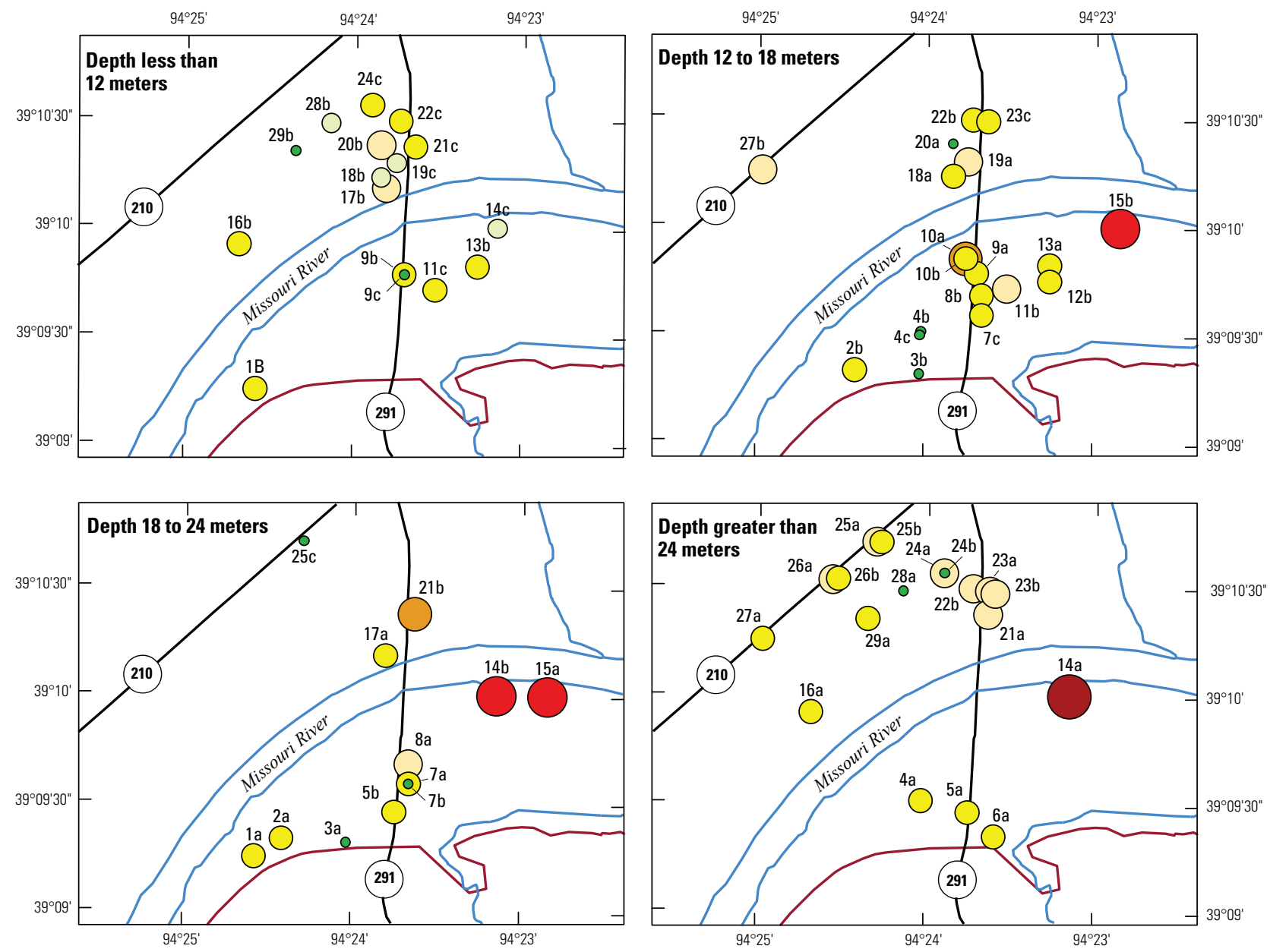

Base from U.S. Geological Survey, digital data 1:100,000, 2005 Universal Transverse Mercator projection Zone 15

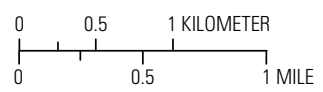

\section{EXPLANATION}

$[\leq$, less than or equal; $>$, greater than $]$

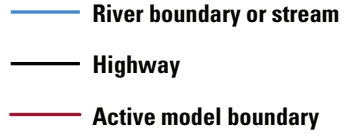

Well, identifier, and median $\mathrm{pH}$, in pH units

3a

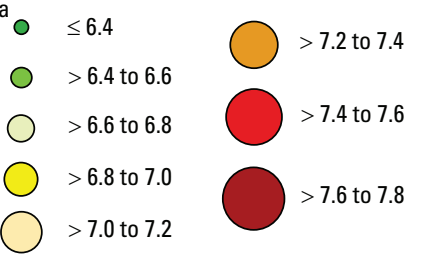

Figure 26. The areal distribution of median values of $\mathrm{pH}$ for water samples from monitoring wells grouped by depth interval. 

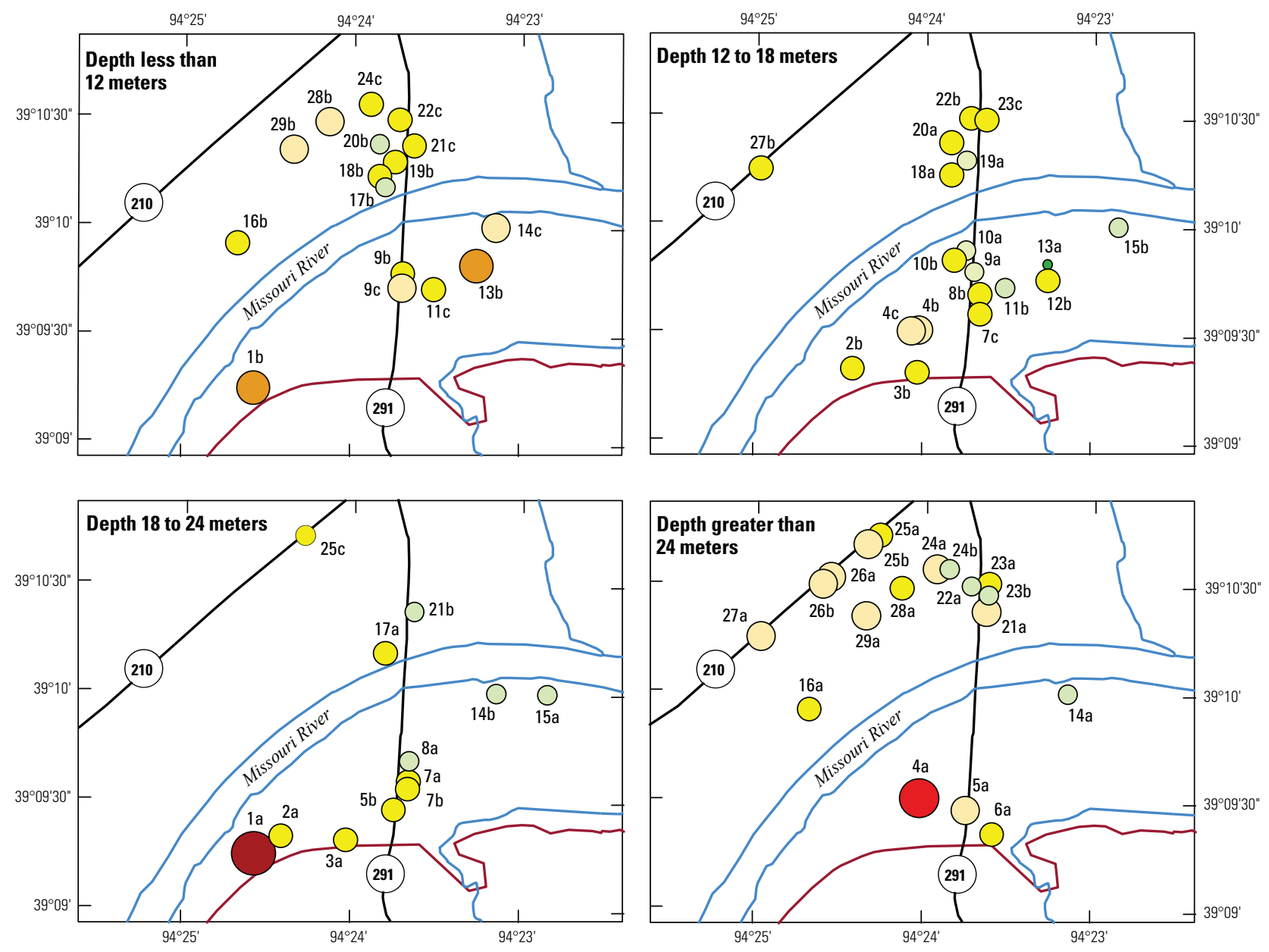

Base from U.S. Geological Survey, digital data 1:100,000, 2005 Universal Transverse Mercator projection Zone 15

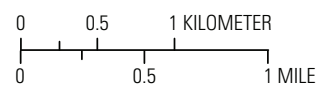

EXPLANATION

$[>$, greater than]

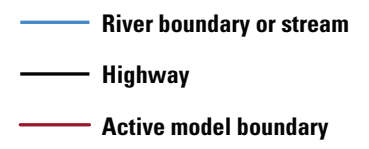

Well, identifier, and median specific conductance, in microseimens per centimeter at 25 degrees Celsius
$3 a$ o 232 to 400
$>\quad>6.4$ to 6.6
$\bigcirc>600$ to 800
$>>800$ to 1,000
$\bigcirc>1,000$ to 1,200

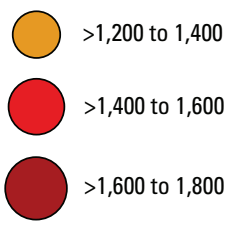

Figure 27. The areal distribution of median values of specific conductance for water samples from monitoring wells grouped by depth interval. 

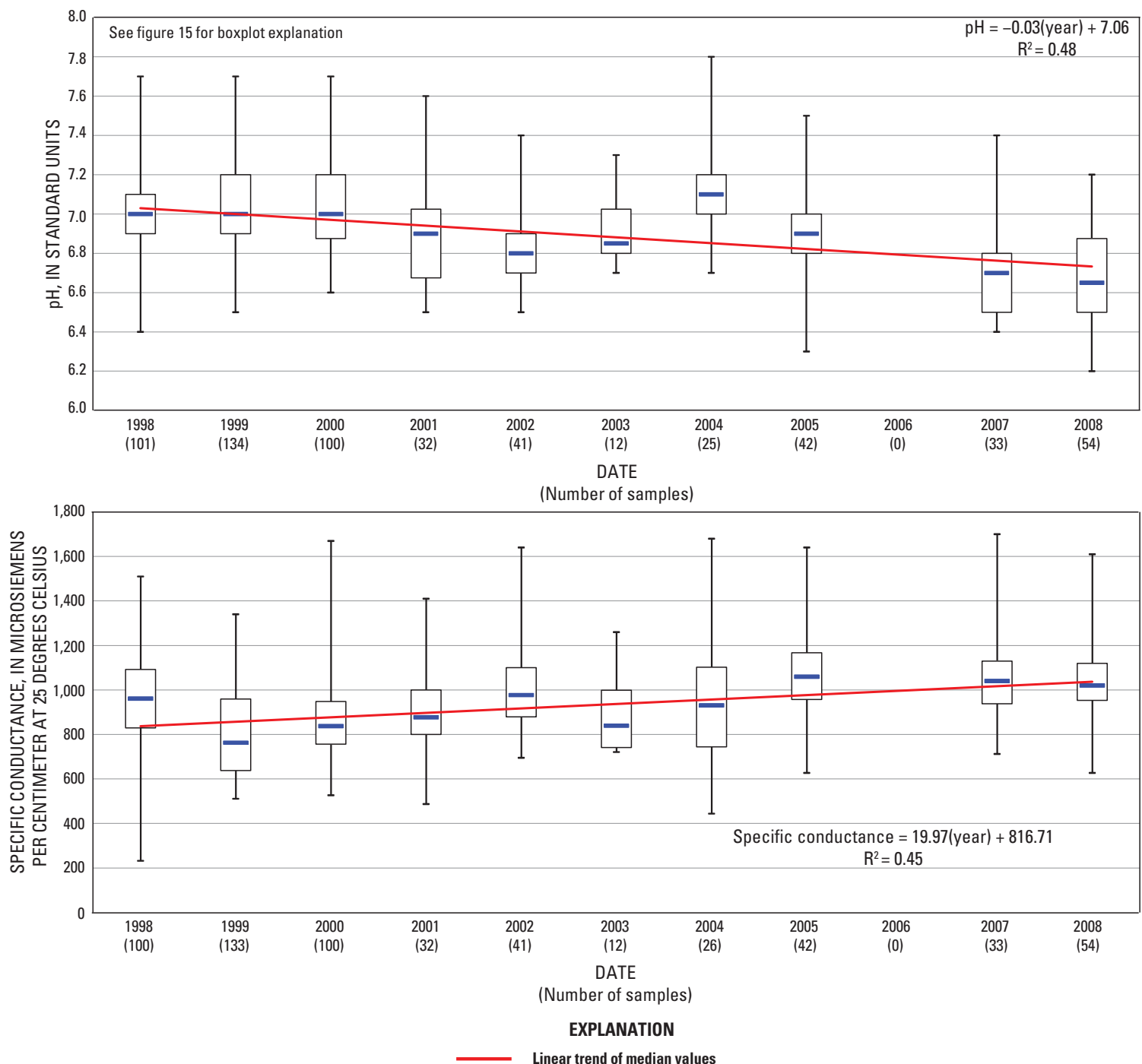

Figure 28. Boxplots and linear trend of median $\mathrm{pH}$ and median specific conductance for water samples from monitoring wells grouped by year.

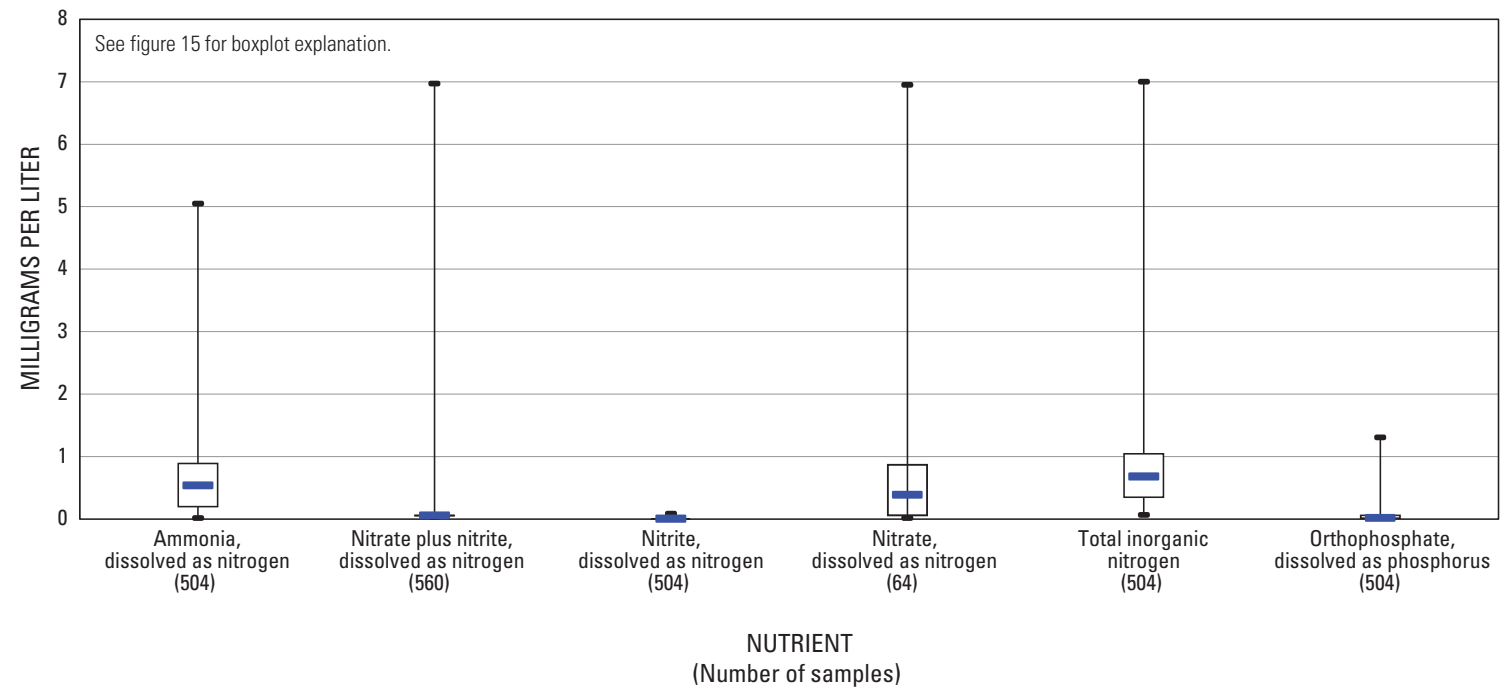

Figure 29. Boxplots of selected nutrients for water samples from all monitoring wells. 


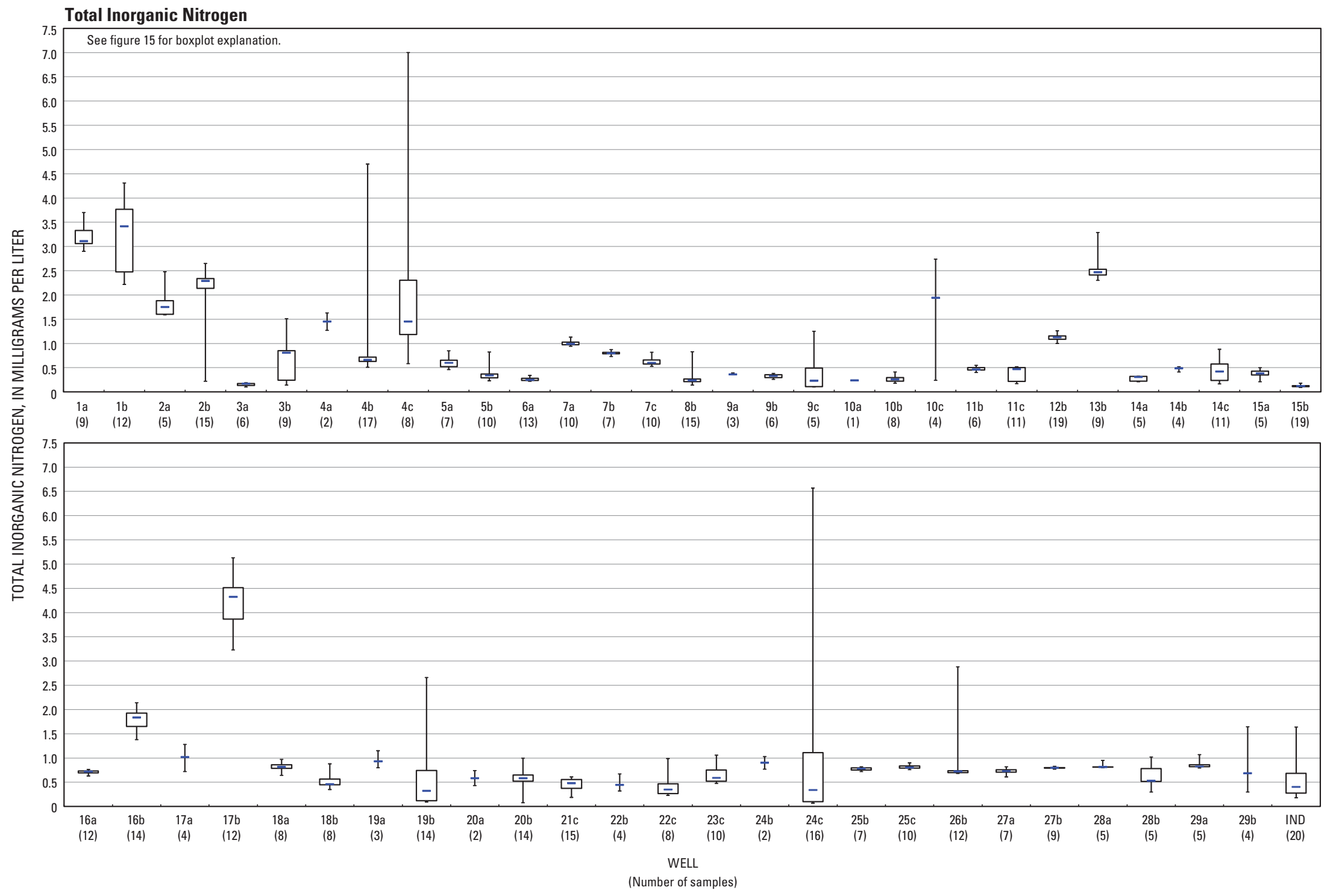

Figure 30. Boxplots of total inorganic nitrogen (ammonia plus nitrate plus nitrite) and orthophosphate for water samples from each monitoring well. 


\section{Orthophosphate}

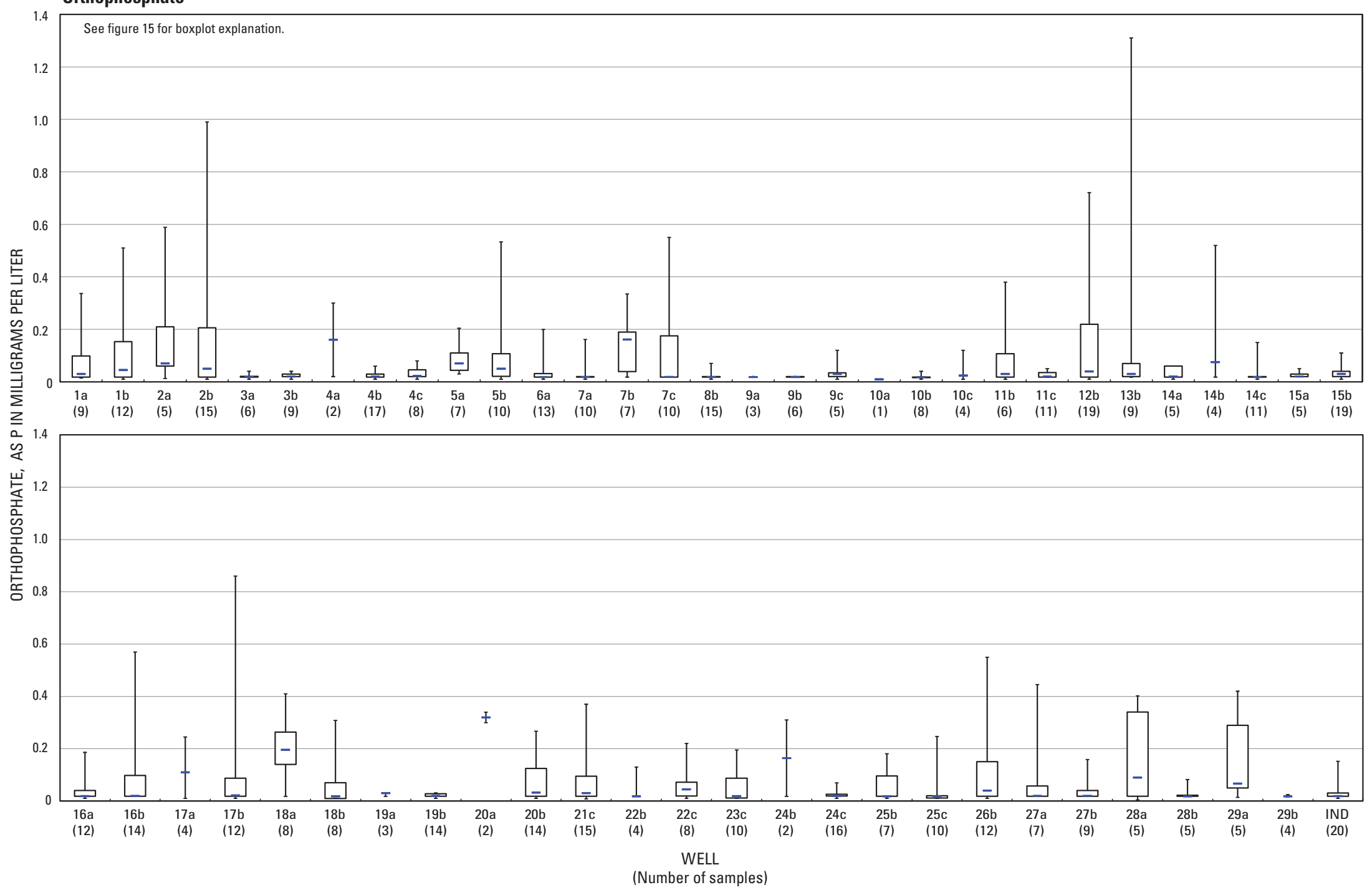

Figure 30. Boxplots of total inorganic nitrogen (ammonia plus nitrate plus nitrite) and orthophosphate for water samples from each monitoring well.—Continued 

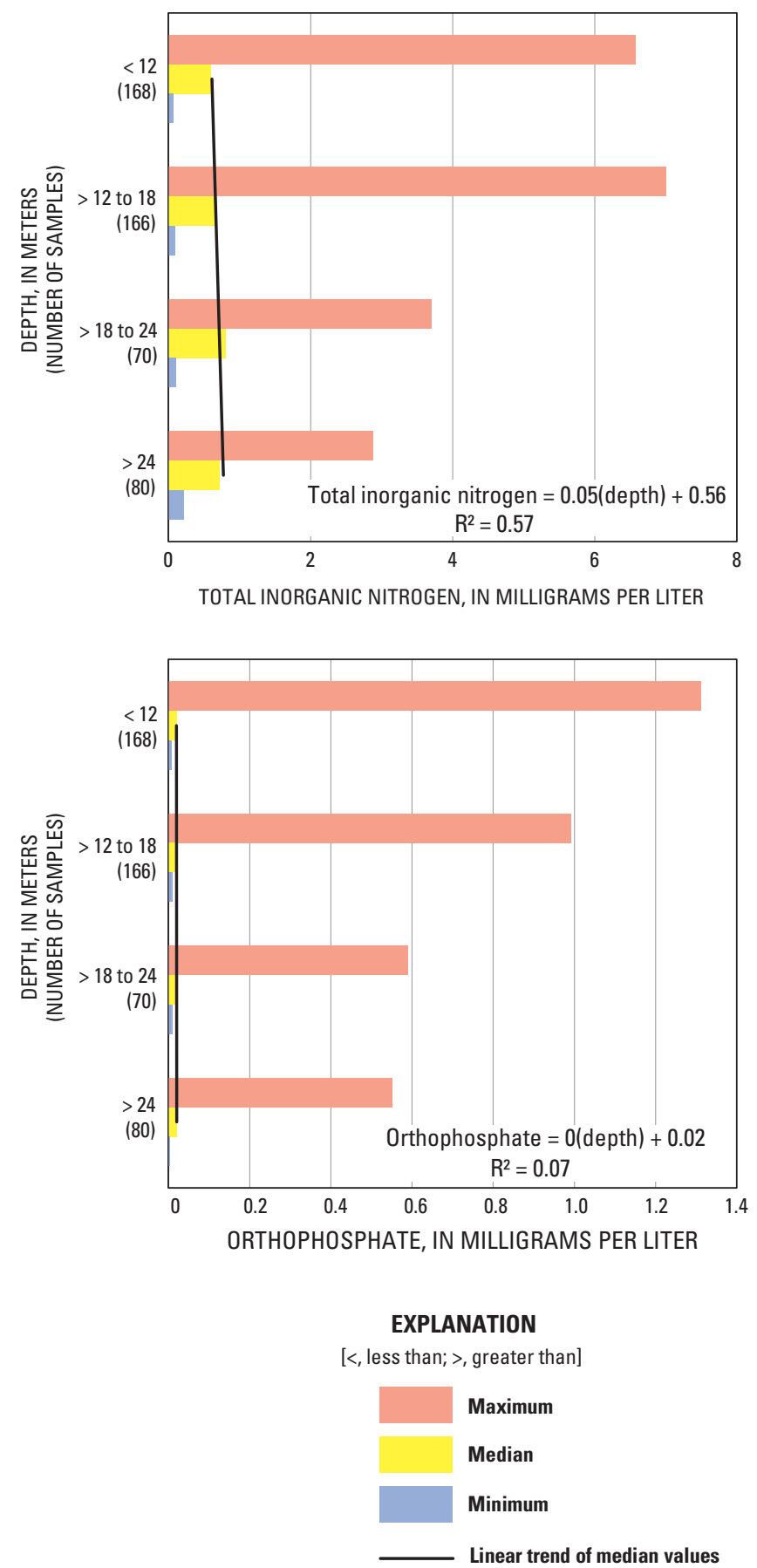

Figure 31. Total inorganic nitrogen (ammonia plus nitrate plus nitrite) and orthophosphate and linear trend of median concentrations for water samples from monitoring wells grouped by depth. 

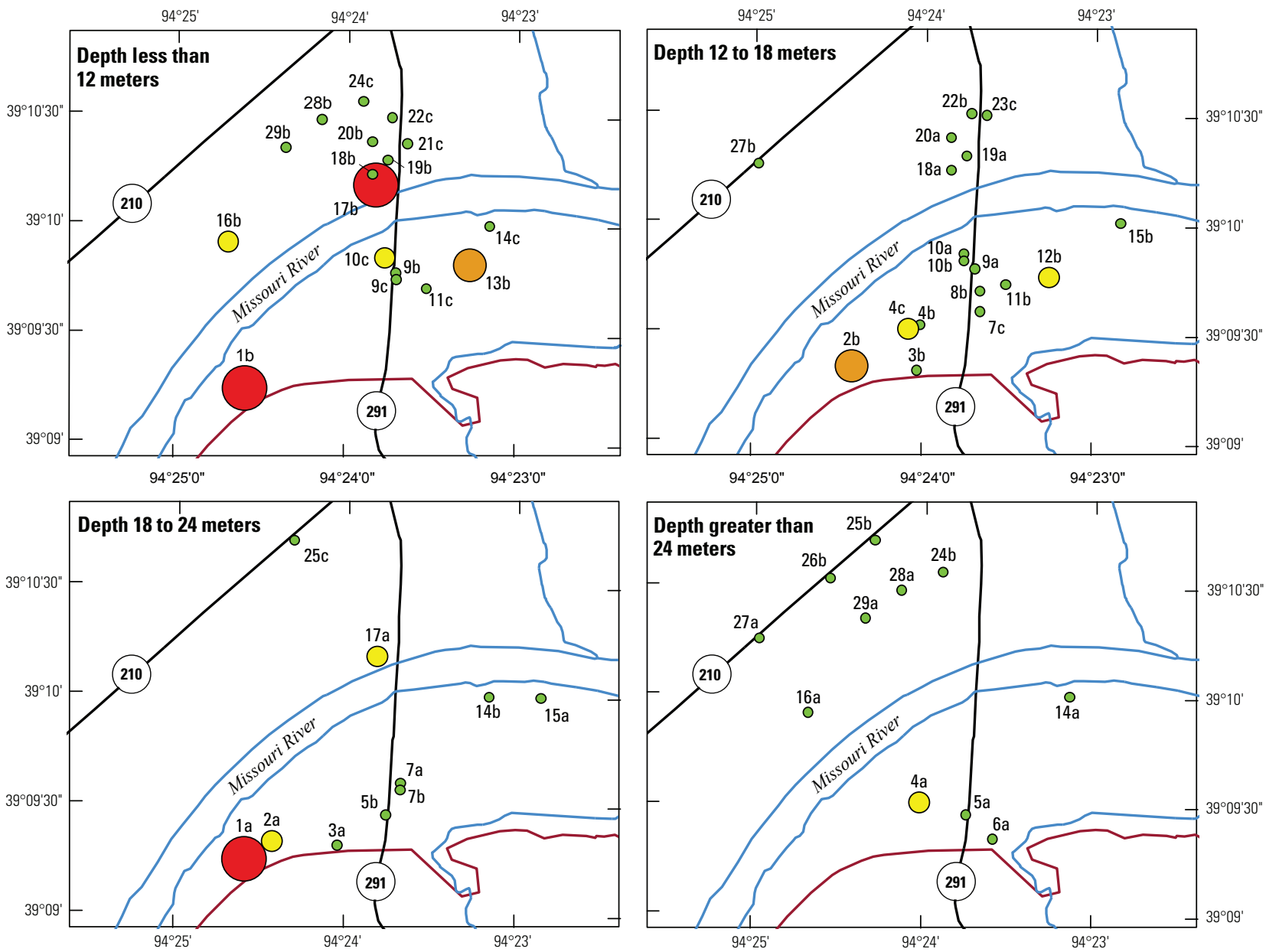

Base from U.S. Geological Survey, digital data 1:100,000, 2005 Universal Transverse Mercator projection Zone 15

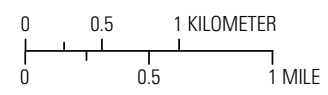

EXPLANATION

[ $>$ greater than]

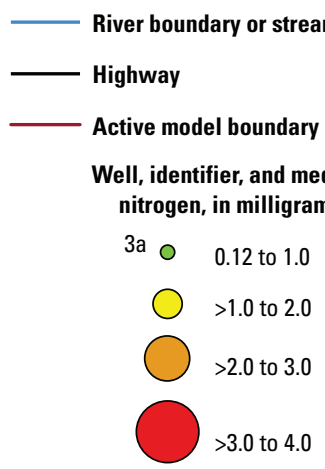

Figure 32. The areal distribution of median concentrations of total inorganic nitrogen (ammonia plus nitrate plus nitrite) for water samples from monitoring wells grouped by depth interval. 
The areal distribution of median concentrations of orthophosphate in groundwater for samples from monitoring wells grouped by depth interval is shown in figure 33. Samples from monitoring wells with median concentrations of orthophosphate greater than $0.1 \mathrm{mg} / \mathrm{L}$ as $\mathrm{P}$ include $18 \mathrm{a}$ and $20 \mathrm{a}$ (12- to $18-\mathrm{m}), 7 \mathrm{~b}$ and $17 \mathrm{a}$ (18- to $24-\mathrm{m})$, and $4 \mathrm{a}$ and $24 \mathrm{~b}$ (> 24-m).

Boxplots and linear trends from 1998 to 2008 of median concentrations of total inorganic nitrogen and orthophosphate for samples from wells grouped by year are shown in figure 34. The linear trend of median concentrations of total inorganic nitrogen increased $0.02 \mathrm{mg} / \mathrm{L}$ per year $\left(\mathrm{R}^{2}=0.56\right)$, and of orthophosphate increased $0.01 \mathrm{mg} / \mathrm{L}$ per year $\left(\mathrm{R}^{2}=0.10\right)$ from 1998 to 2008 . The low rate of change of the linear trend of median concentrations of both total inorganic nitrogen and orthophosphate indicate little variation of these between 1998 and 2008, and the $\mathrm{R}^{2}$ values indicate 56 percent of the variation of total inorganic nitrogen and only 10 percent of the variation of orthophosphate is related to time.

\section{Major lons and Trace Elements}

Comparisons of maximum contaminant levels (MCLs) and secondary maximum contaminant levels (SMCLs) for major ions and trace elements in drinking water (Missouri Department of Natural Resources, 2003) to the analytical results obtained from filtered samples collected from monitoring wells during this study are for illustrative purposes only. Dissolved major ions include calcium, magnesium, potassium, sodium, carbonate, bicarbonate, chloride, fluoride, sulfate, and silica. Although iron is considered a trace element, it is included with the discussion of major ions because it was detected at relatively high concentrations in almost all samples. Acid neutralizing capacity (ANC) is a measure of the ability of an unfiltered water sample to neutralize strong acid. $\mathrm{ANC}$ is equivalent to alkalinity in samples without titratable particulate matter (Rounds, 2006). Boxplots of dissolved major ions and iron in water samples from all monitoring wells are shown in figure 35 . Groundwater was dominated by calcium, carbonate (ANC), and bicarbonate ions (fig. 35).

Boxplots of dissolved major ions and iron in water samples from each monitoring well are shown in figure 36 . The MCLs and SMCLs for drinking water for chloride, fluoride, sulfate, and iron (Missouri Department of Natural Resource, 2003) are listed in table 9. No samples analyzed for chloride or fluoride exceeded the MCL ( $250 \mathrm{mg} / \mathrm{L}$ for chloride and $2 \mathrm{mg} / \mathrm{L}$ for fluoride); however, the SMCL for sulfate $(250 \mathrm{mg} / \mathrm{L})$ was equaled or exceeded in samples from monitoring well 1a and almost exceeded in samples from monitoring well 4a. The Missouri SMCL for iron [300 micrograms per liter $(\mu \mathrm{g} / \mathrm{L})$ ] was exceeded in samples from all monitoring wells, except wells 3a, 3b, 10a, 14a, and 20a. Samples from well nest 1 generally had the largest maximum concentrations for calcium, magnesium, sodium, sulfate, and silica, and the largest median concentrations for calcium, magnesium, iron, and sulfate.
MCLs or SMCLs for drinking water for total recoverable aluminum, antimony, arsenic, barium, cadmium, chromium, copper, cyanide, lead, manganese, mercury, selenium, thallium, and zinc are listed in table 9. Boxplots of dissolved trace elements in water samples from all monitoring wells are shown in figure 37. Boxplots of dissolved antimony, arsenic, barium, and manganese in water samples from each monitoring well are shown in figure 38. The MCL for antimony $(6 \mu \mathrm{g} / \mathrm{L})$ was exceeded once in a sample from monitoring well $16 \mathrm{~b}(7 \mu \mathrm{g} / \mathrm{L})$ and equaled once in a sample from monitoring well $22 b$. The MCL for arsenic $(10 \mu \mathrm{g} / \mathrm{L})$ was exceeded 32 times in samples from monitoring wells $1 \mathrm{~b}, 2 \mathrm{a}, 2 \mathrm{~b}, 9 \mathrm{c}, 10 \mathrm{c}$, $16 \mathrm{~b}, 22 \mathrm{~b}, 28 \mathrm{~b}$, and 29b. The MCL for barium $(2,000 \mu \mathrm{g} / \mathrm{L})$ was exceeded five times in samples from monitoring well 16a. The MCL for lead $(15 \mu \mathrm{g} / \mathrm{L})$ may have been exceeded once in monitoring well $16 \mathrm{~b}$ (estimated $50 \mu \mathrm{g} / \mathrm{L}$ ) and once in the combined well-field sample, (IND) (estimated $60 \mu \mathrm{g} / \mathrm{L}$ ), but all other samples analyzed were at or near the LRL of $0.08 \mu \mathrm{g} / \mathrm{L}$. The SMCL for manganese $(50 \mu \mathrm{g} / \mathrm{L})$ was exceeded 160 times in samples from all monitoring wells and IND. The MCL for selenium $(50 \mu \mathrm{g} / \mathrm{L})$ was exceeded in well $24 \mathrm{c}$ in one sample.

Maximum, median, and minimum concentrations for major ions and iron in samples and linear trend of median concentrations for monitoring wells grouped by depth interval are shown in figure 39. The linear trend of median concentrations of calcium, potassium, and sulfate decrease with depth interval and median magnesium, bicarbonate, sodium, chloride, fluoride, iron, and silica increased with depth interval. Correlation coefficients for calcium, magnesium, chloride, fluoride, and iron were less than 0.1 , indicating little relation between variation of these constituents and depth interval. Larger correlation coefficients for sodium $(0.32)$, potassium $(0.96)$, bicarbonate $(0.28)$, sulfate $(0.48)$, and silica ( 0.49$)$ indicate their variability has some relation to depth interval. Maximum concentrations for calcium, magnesium, sodium, sulfate, and silica were from samples from monitoring well $1 \mathrm{a}$ in the 18- to 24-m depth interval. A maximum concentration for potassium was from samples from well 9c in the $<12-\mathrm{m}$ depth interval. Maximum concentrations for ANC, bicarbonate, and chloride are from a sample from monitoring well $5 \mathrm{a}$ in the $>24-\mathrm{m}$ depth interval. Maximum concentration of iron is from a sample from monitoring well $22 \mathrm{c}$ in the $<12-\mathrm{m}$ depth interval.

Maximum, median, and minimum concentrations for antimony, arsenic, barium, and manganese in samples and linear trends of median concentrations for samples from monitoring wells grouped by depth interval are shown in figure 40 . The linear trend of median concentrations of antimony is constant with depth interval. The linear trend of median concentrations of arsenic decreased $2.8 \mu \mathrm{g} / \mathrm{L}$ with depth interval $\left(\mathrm{R}^{2}=0.62\right)$, of barium increased about $98 \mu \mathrm{g} / \mathrm{L}$ with depth interval $\left(R^{2}=0.49\right)$, and of manganese decreased about $230 \mu \mathrm{g} / \mathrm{L}$ with depth interval $\left(\mathrm{R}^{2}=0.47\right)$. Correlation coefficients for arsenic, barium, and manganese indicate their variability had some relation to depth interval. Maximum concentrations of antimony, arsenic, and manganese were in the $<12-\mathrm{m}$ depth interval, and a maximum concentration for barium was in the $>24-\mathrm{m}$ depth interval. Median concentrations of arsenic were largest in the 

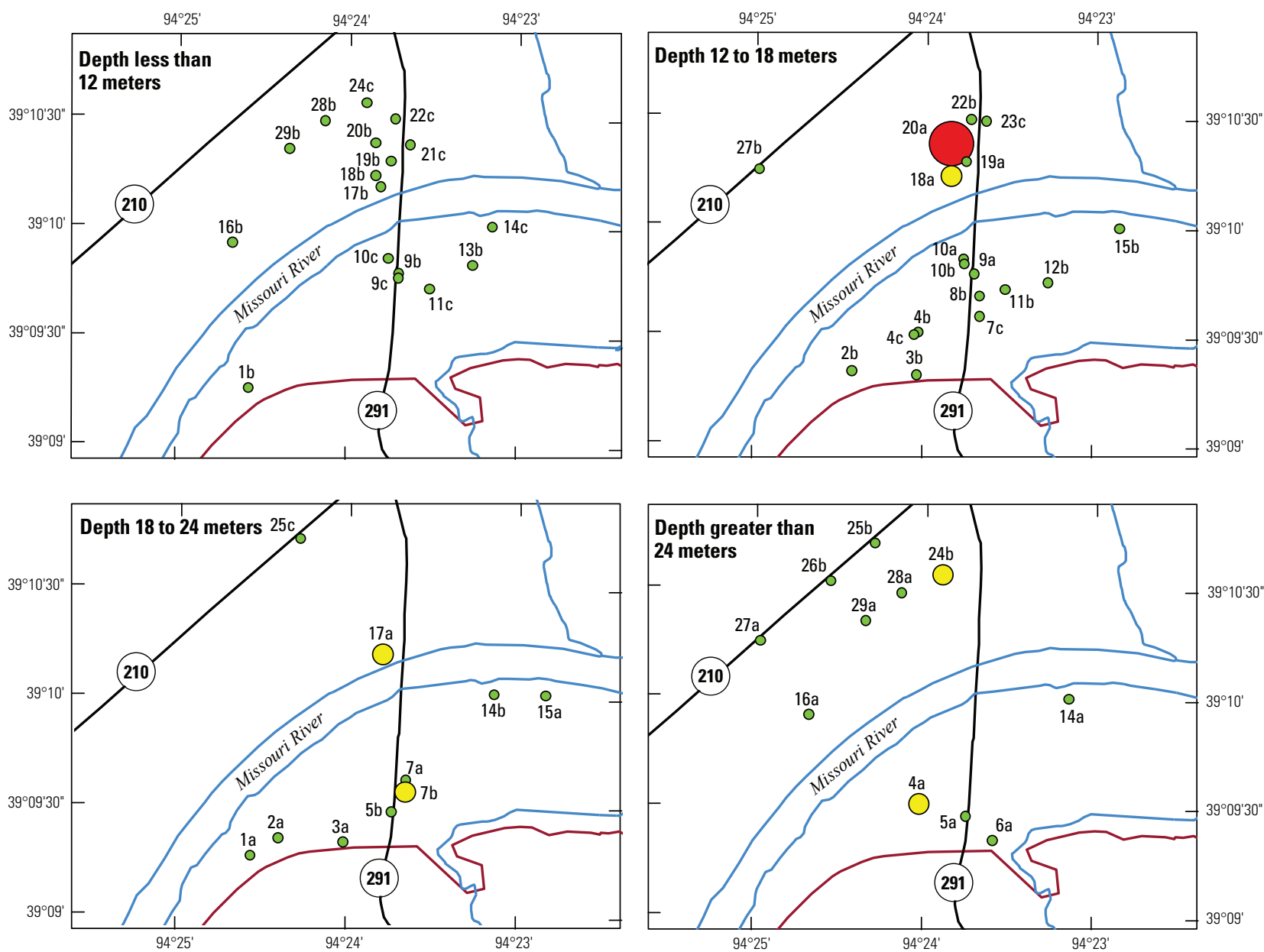

Base from U.S. Geological Survey, digital data 1:100,000, 2005 Universal Transverse Mercator projection Zone 15

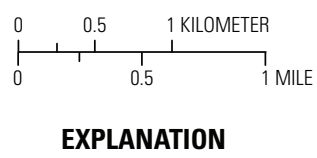

[>, greater than]

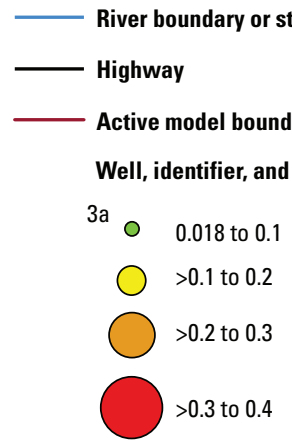

Figure 33. The areal distribution of median concentrations of orthophosphate for water samples from monitoring wells grouped by depth interval. 

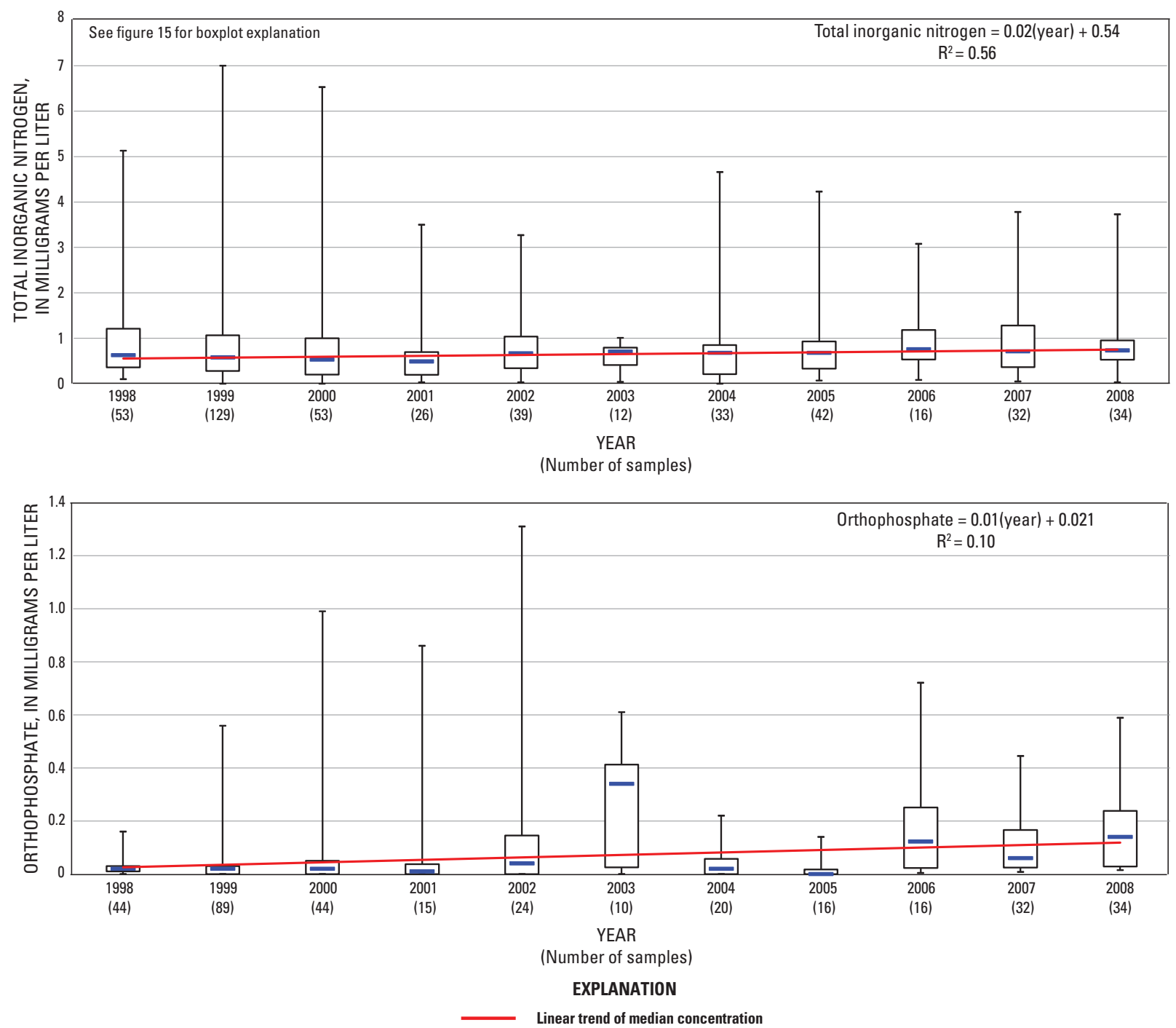

Figure 34. Boxplots and linear trend from 1998 to 2008 of median concentrations of total inorganic nitrogen (ammonia plus nitrate plus nitrite) and orthophosphate for water samples from monitoring wells grouped by year.

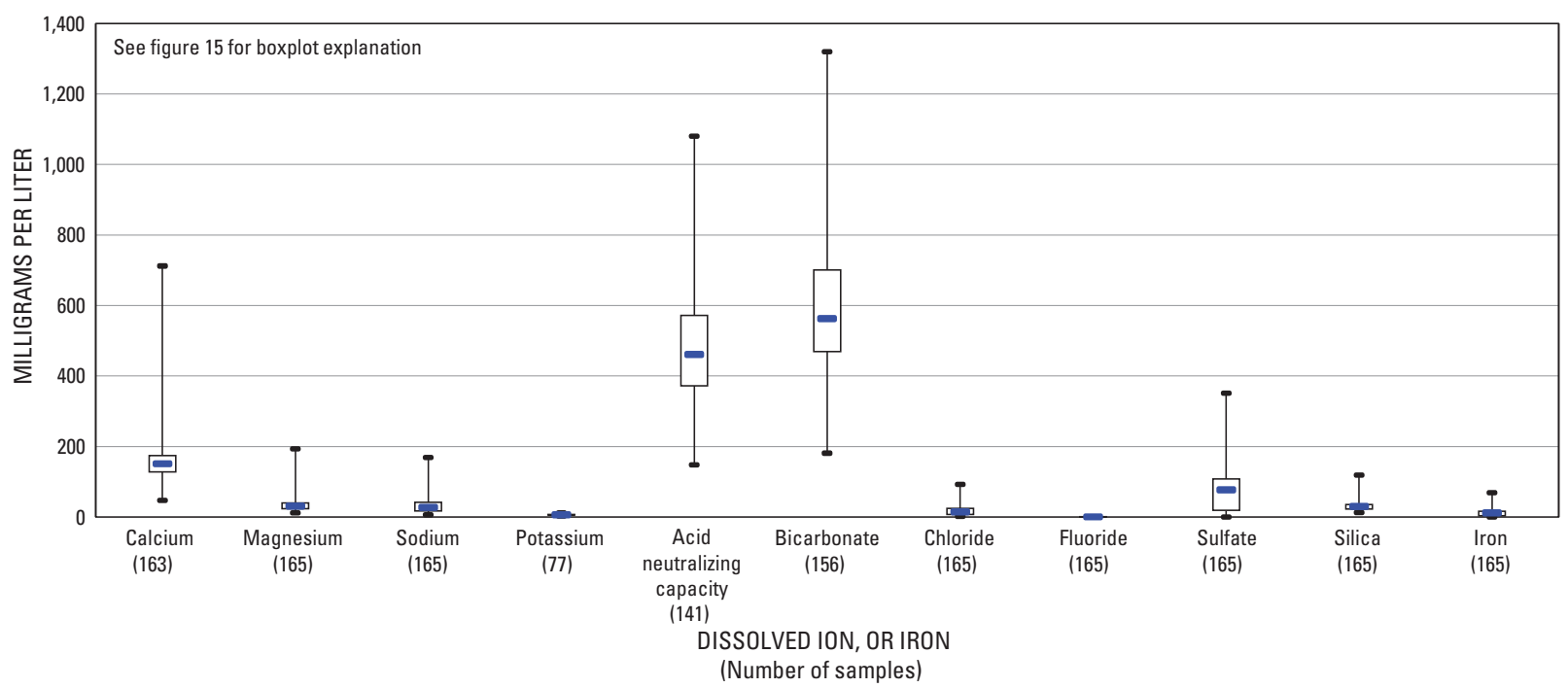

Figure 35. Boxplots of dissolved major ions and iron for water samples from all monitoring wells. 

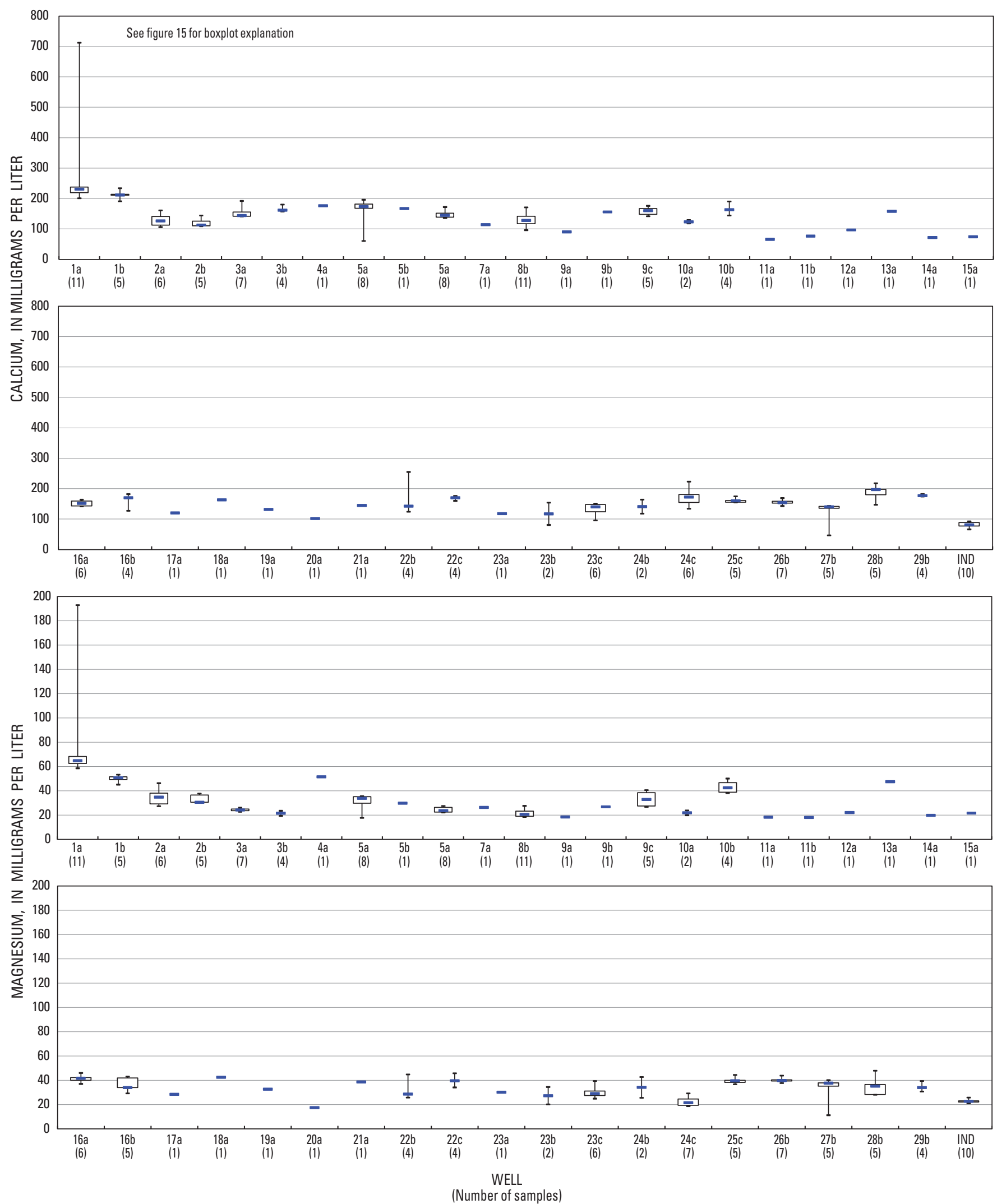

Figure 36. Boxplots of dissolved major ions and iron for water samples from each monitoring well. 

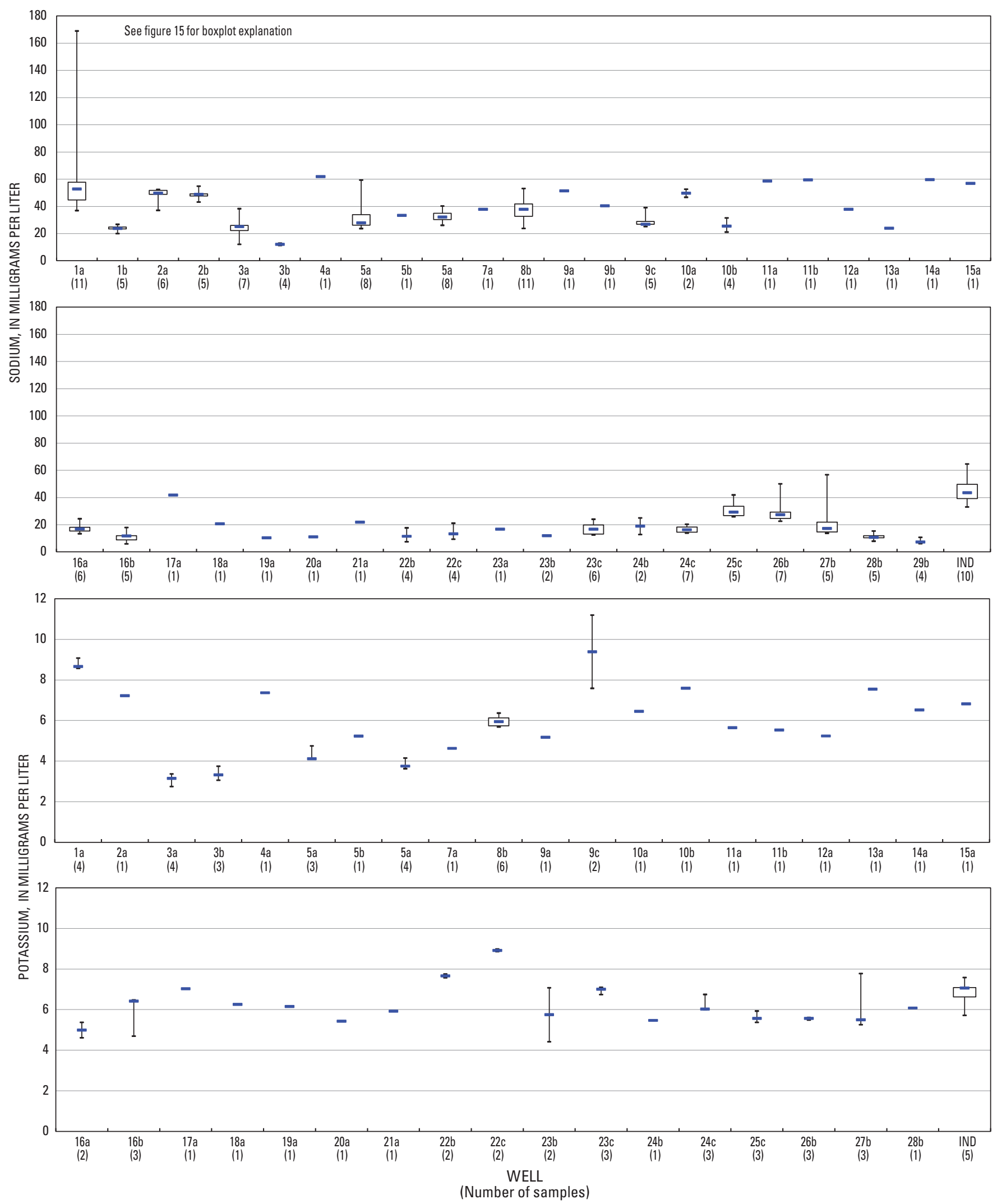

Figure 36. Boxplots of dissolved major ions and iron for water samples from each monitoring well._Continued 

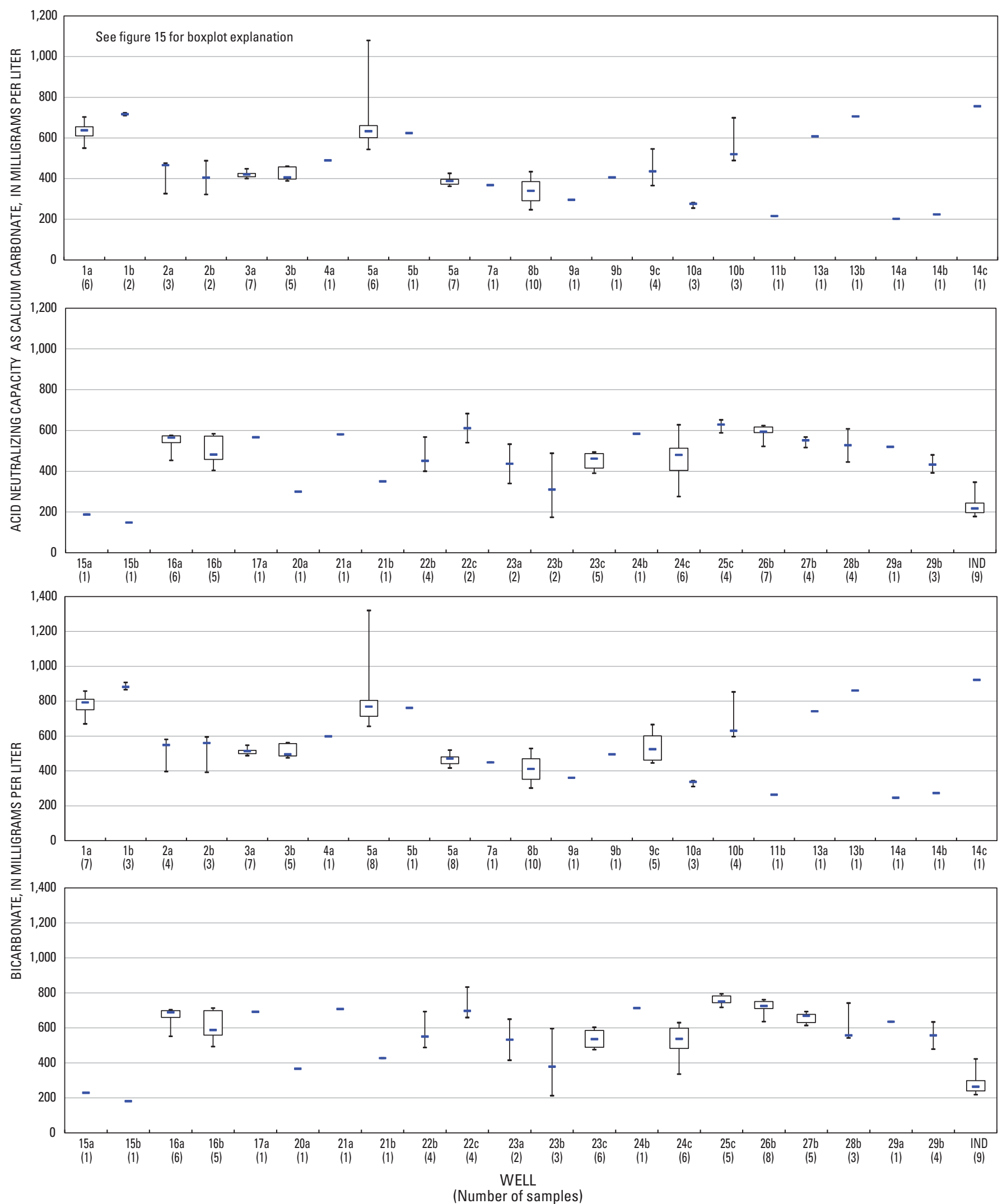

Figure 36. Boxplots of dissolved major ions and iron for water samples from each monitoring well.-Continued 

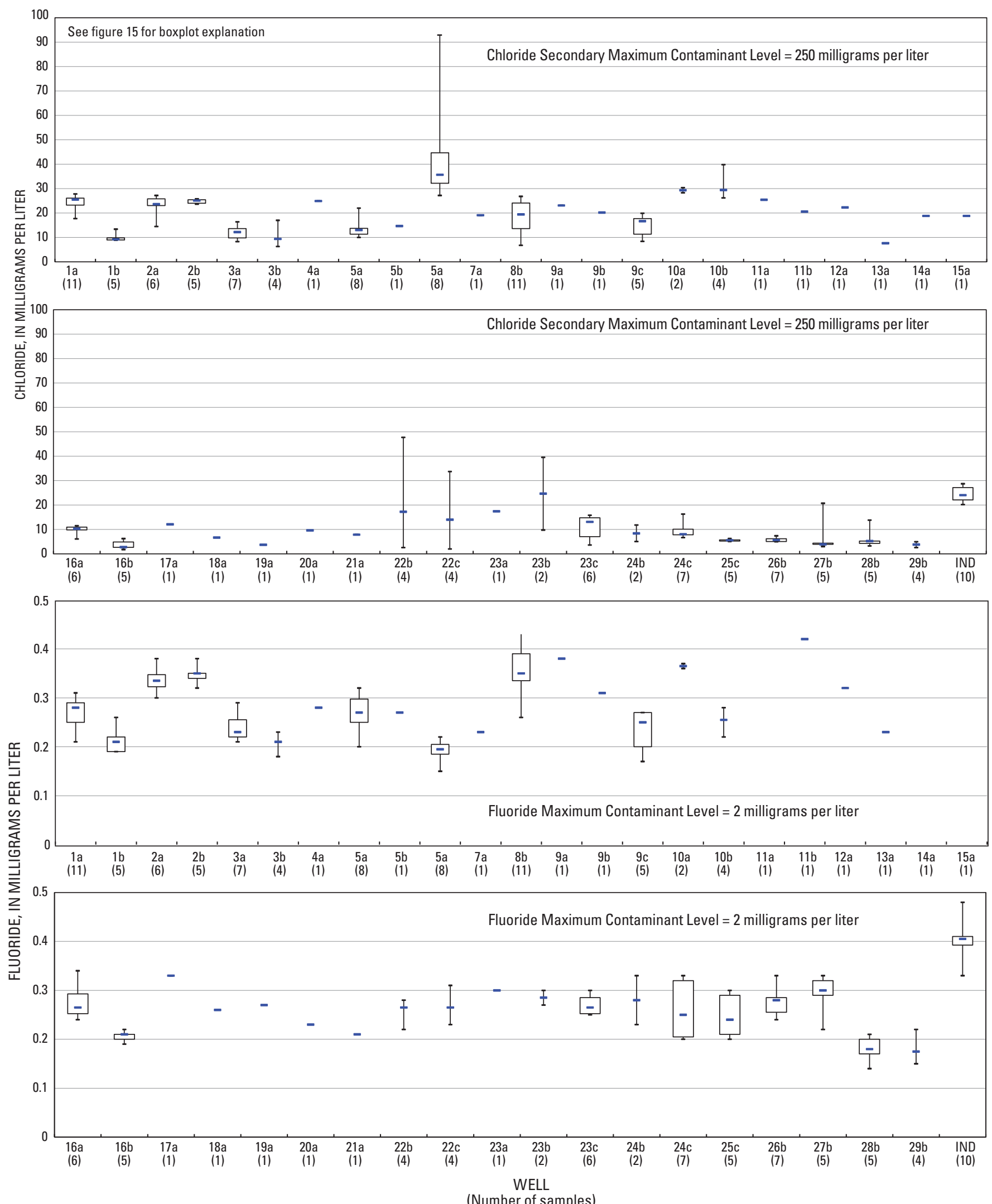

Figure 36. Boxplots of dissolved major ions and iron for water samples from each monitoring well._Continued 

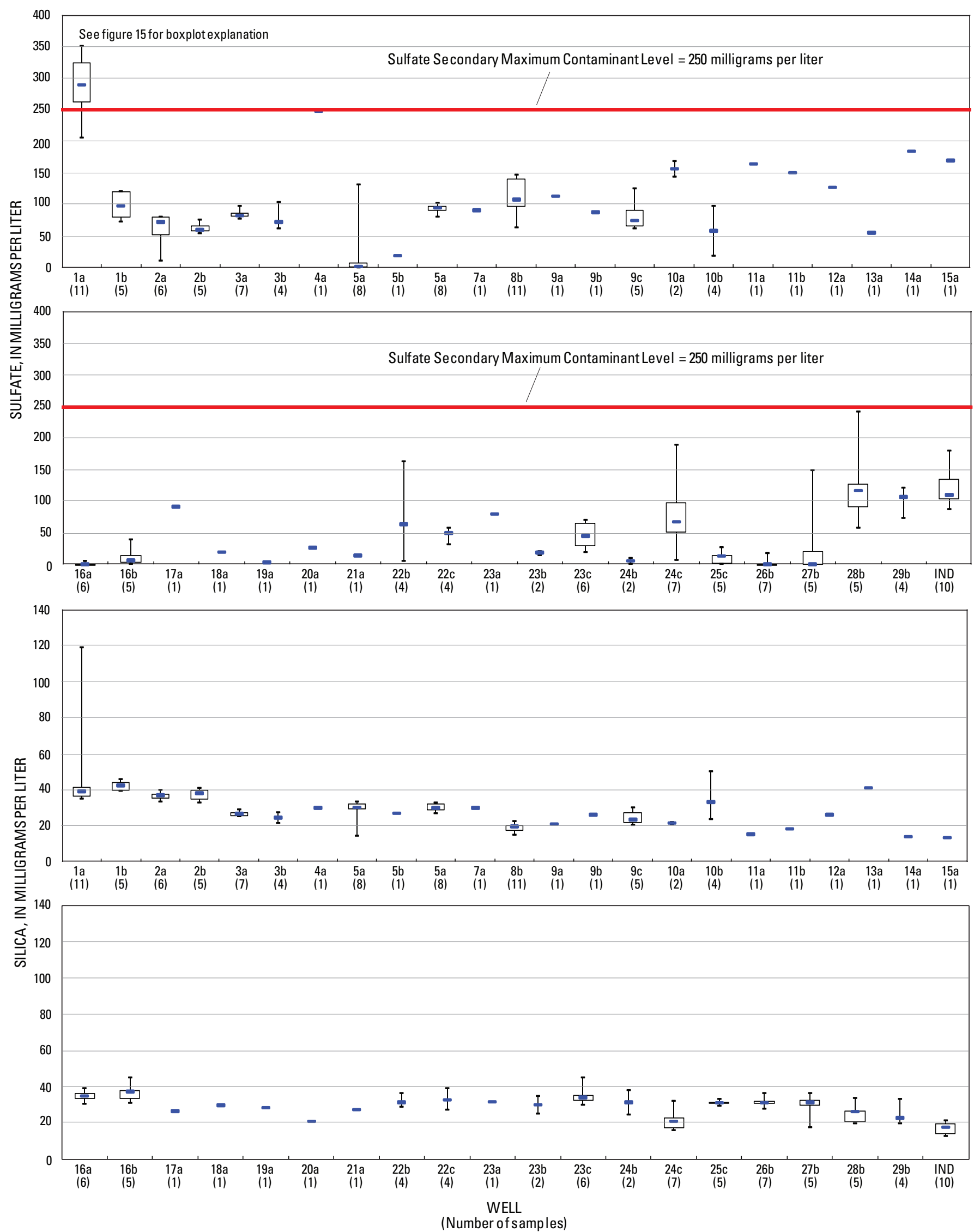

Figure 36. Boxplots of dissolved major ions and iron for water samples from each monitoring well._-Continued 


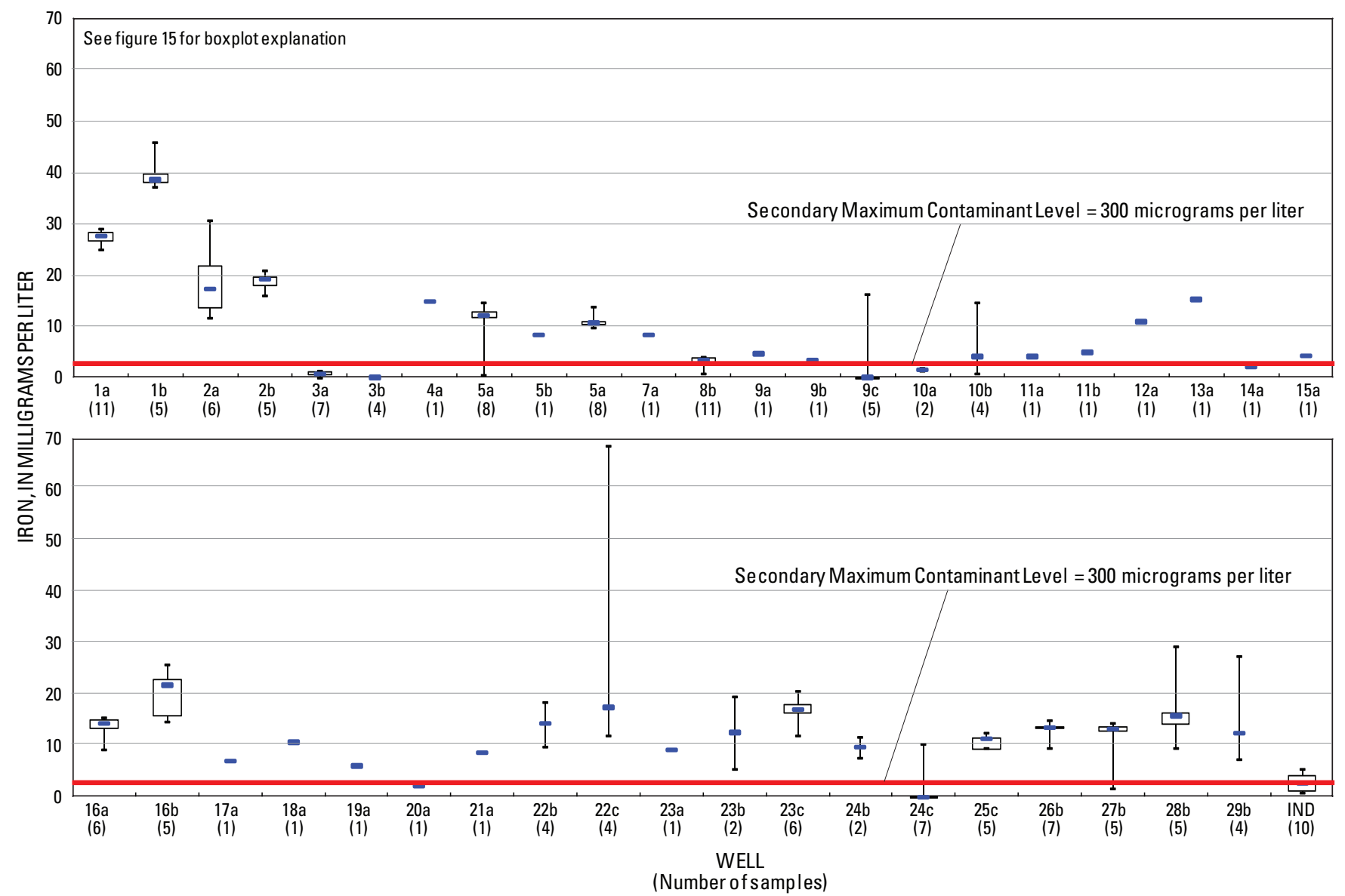

Figure 36. Boxplots of dissolved major ions and iron for water samples from each monitoring well.—Continued 


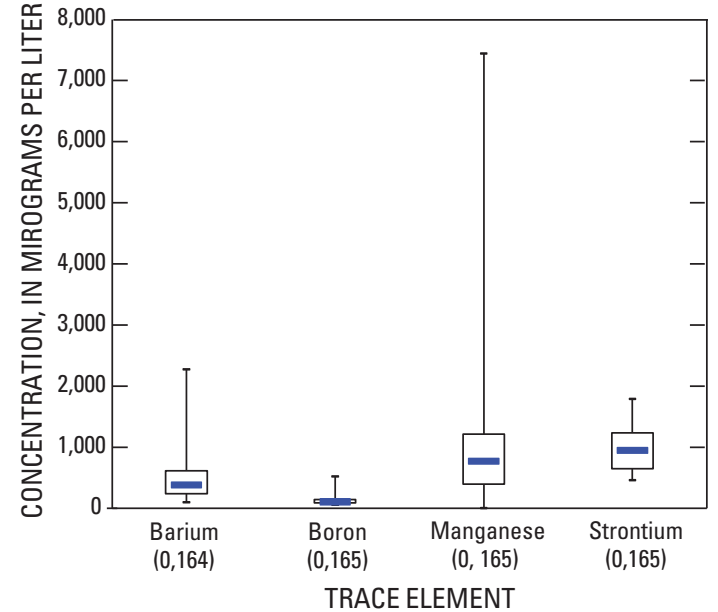

(Samples below laboratory reporting level, total number of samples)

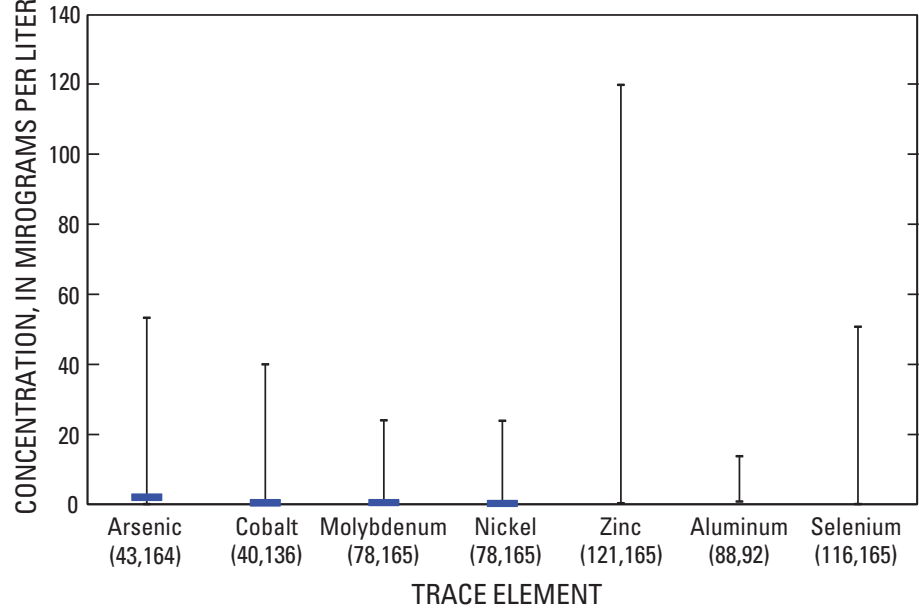

(Samples below laboratory reporting level, total number of samples)

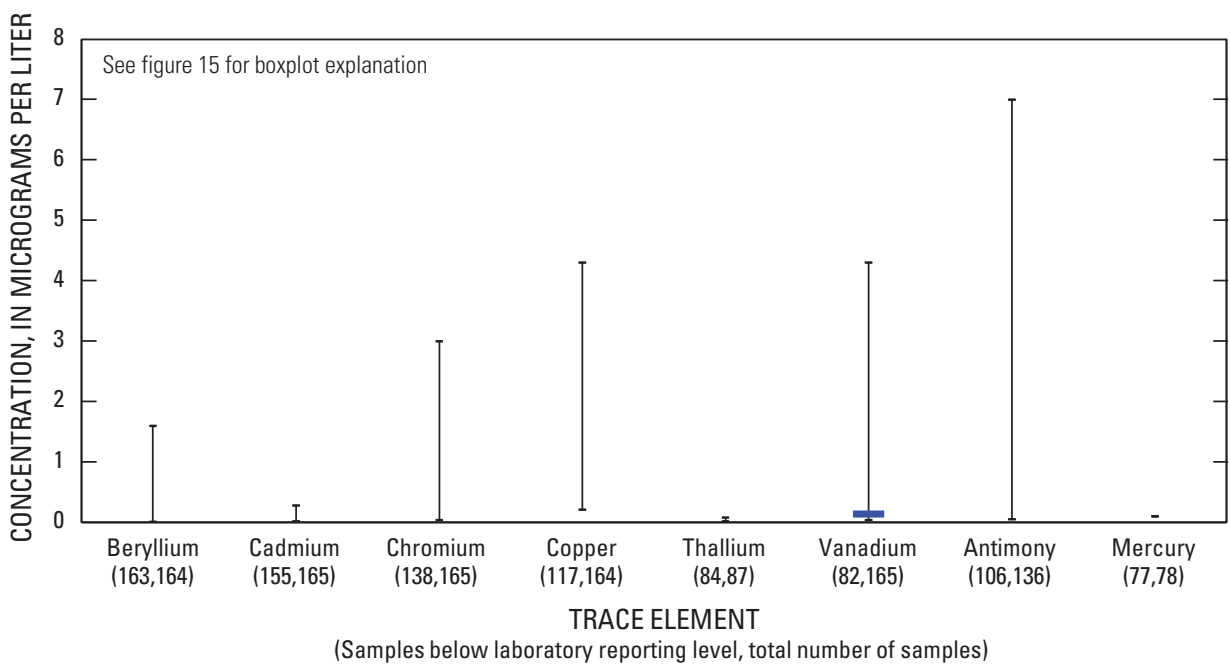

Figure 37. Boxplots of dissolved trace elements for water samples from all monitoring wells. 

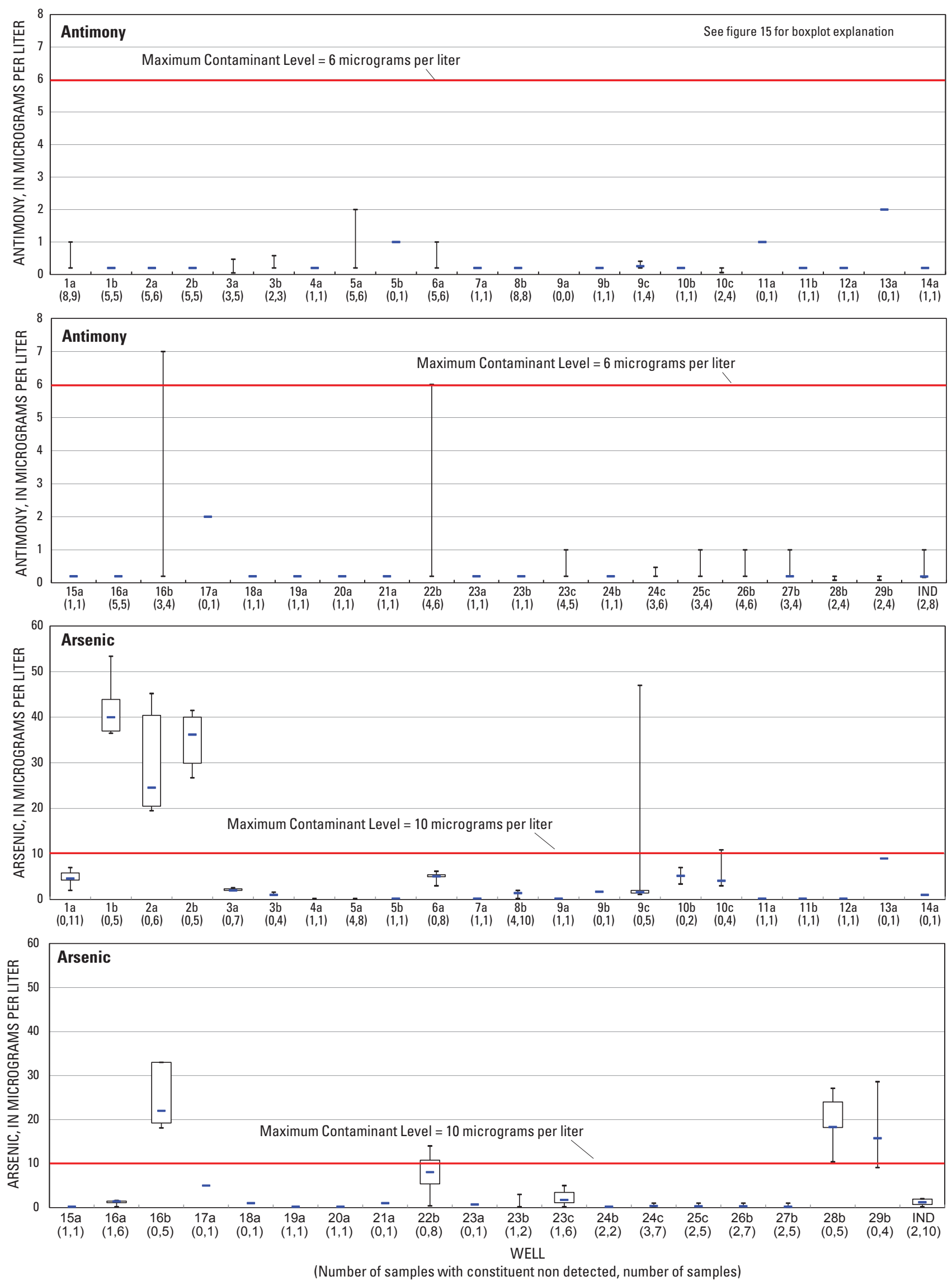

Figure 38. Boxplots of dissolved antimony, arsenic, barium, manganese for water samples from each monitoring well. 

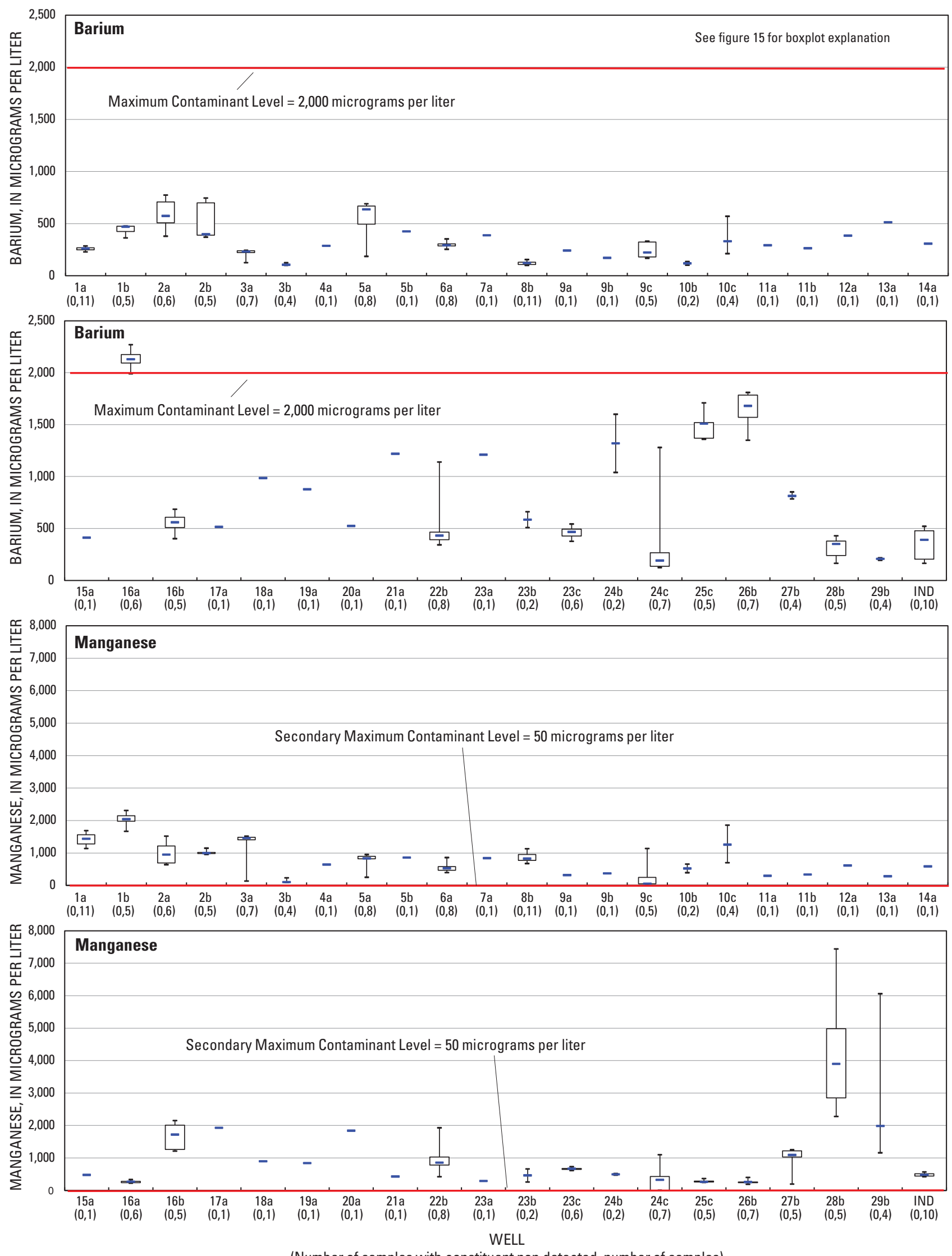

(Number of samples with constituent non detected, number of samples)

Figure 38. Boxplots of dissolved antimony, arsenic, barium, manganese for water samples from each monitoring well.—Continued 

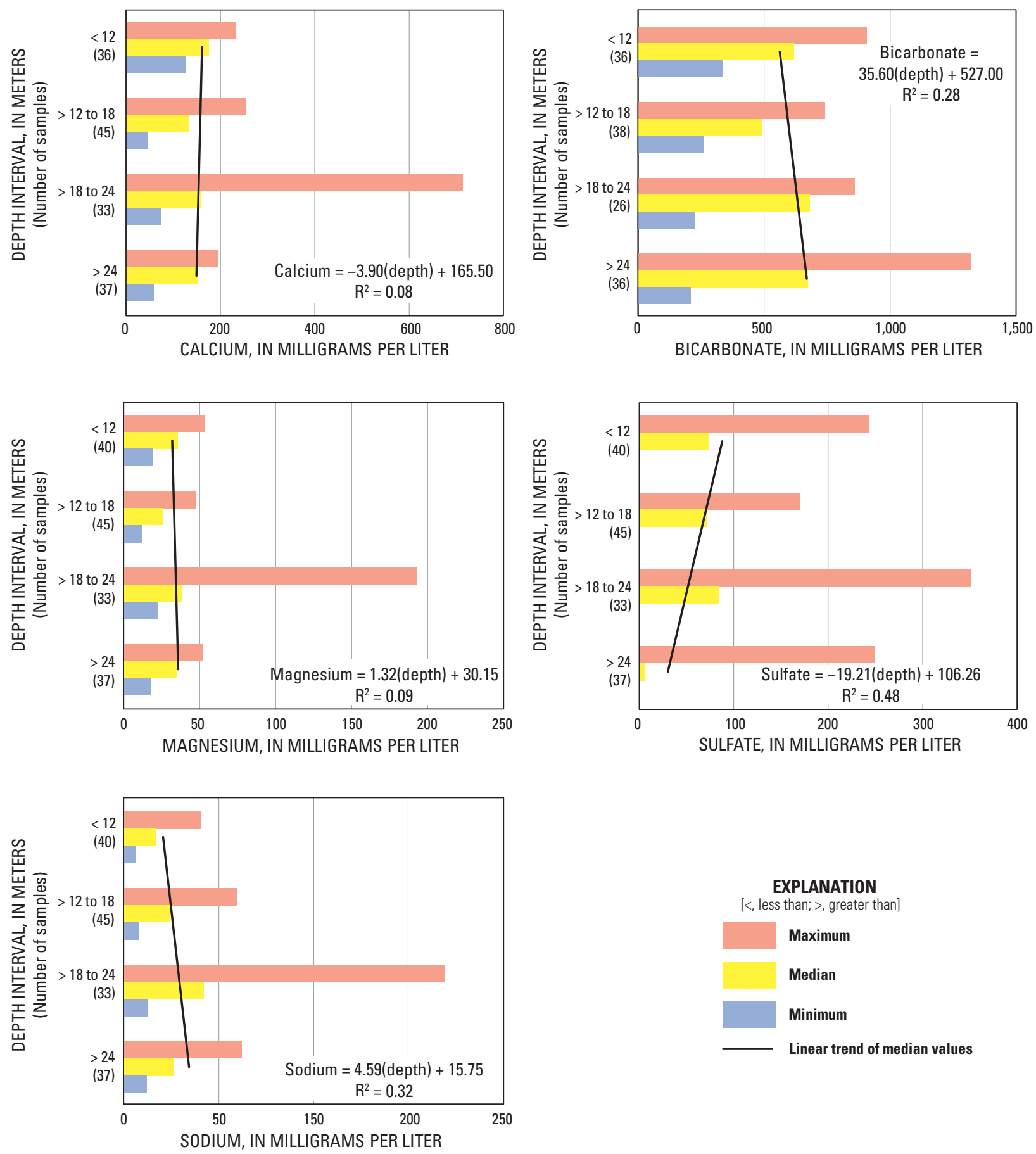

EXPLANATION

$[<$, less than; $>$, greater than $]$

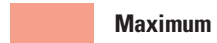

Median

Minimum

Linear trend of median values

Figure 39. Major ions and iron concentrations and linear trend of median concentrations for water samples from monitoring wells grouped by depth interval. 

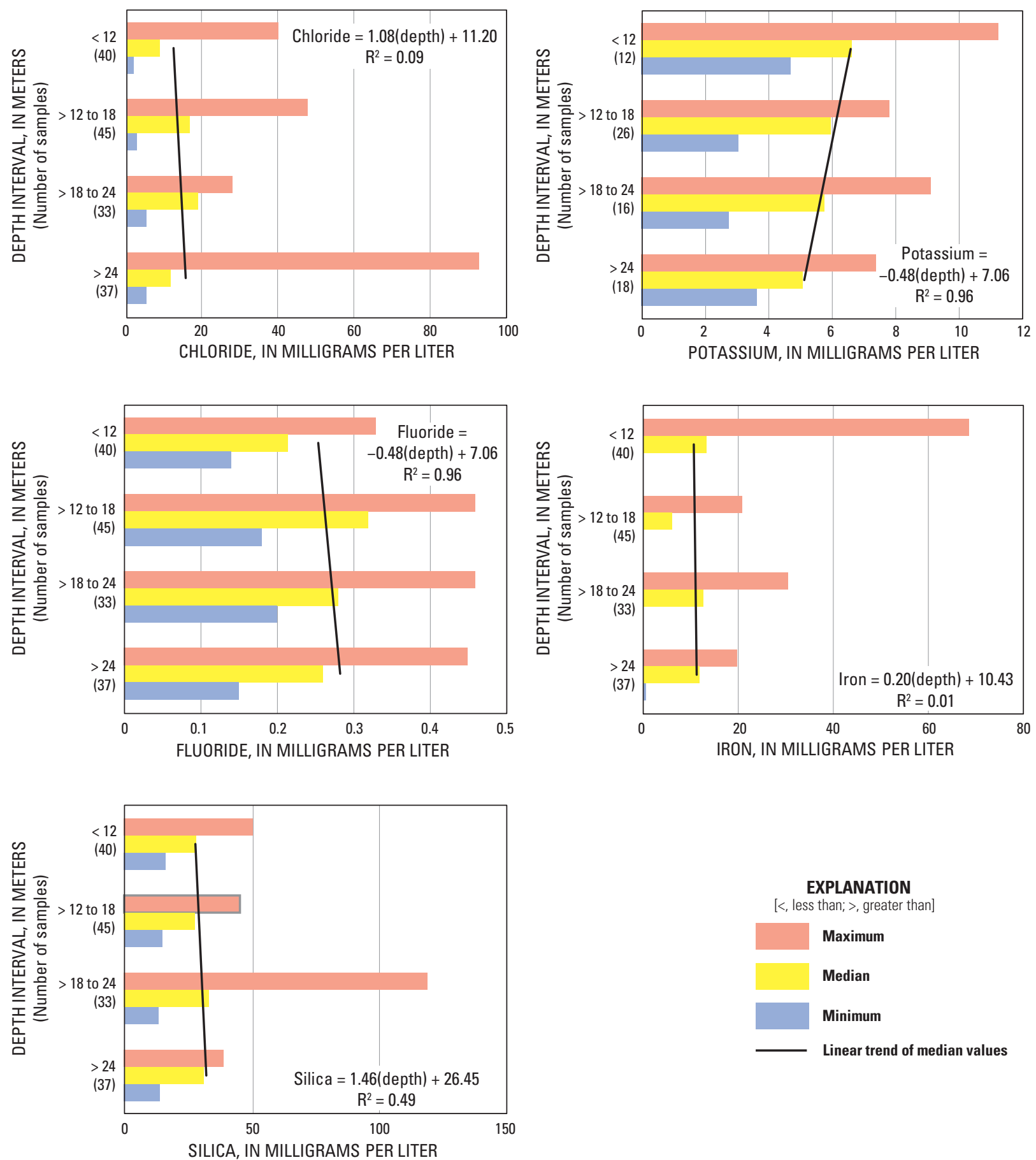

EXPLANATION

$[<$, less than; $>$, greater than $]$

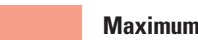

Median

Minimum

Linear trend of median values

Figure 39. Major ions and iron concentrations and linear trend of median concentrations for water samples from monitoring wells grouped by depth interval.-Continued 

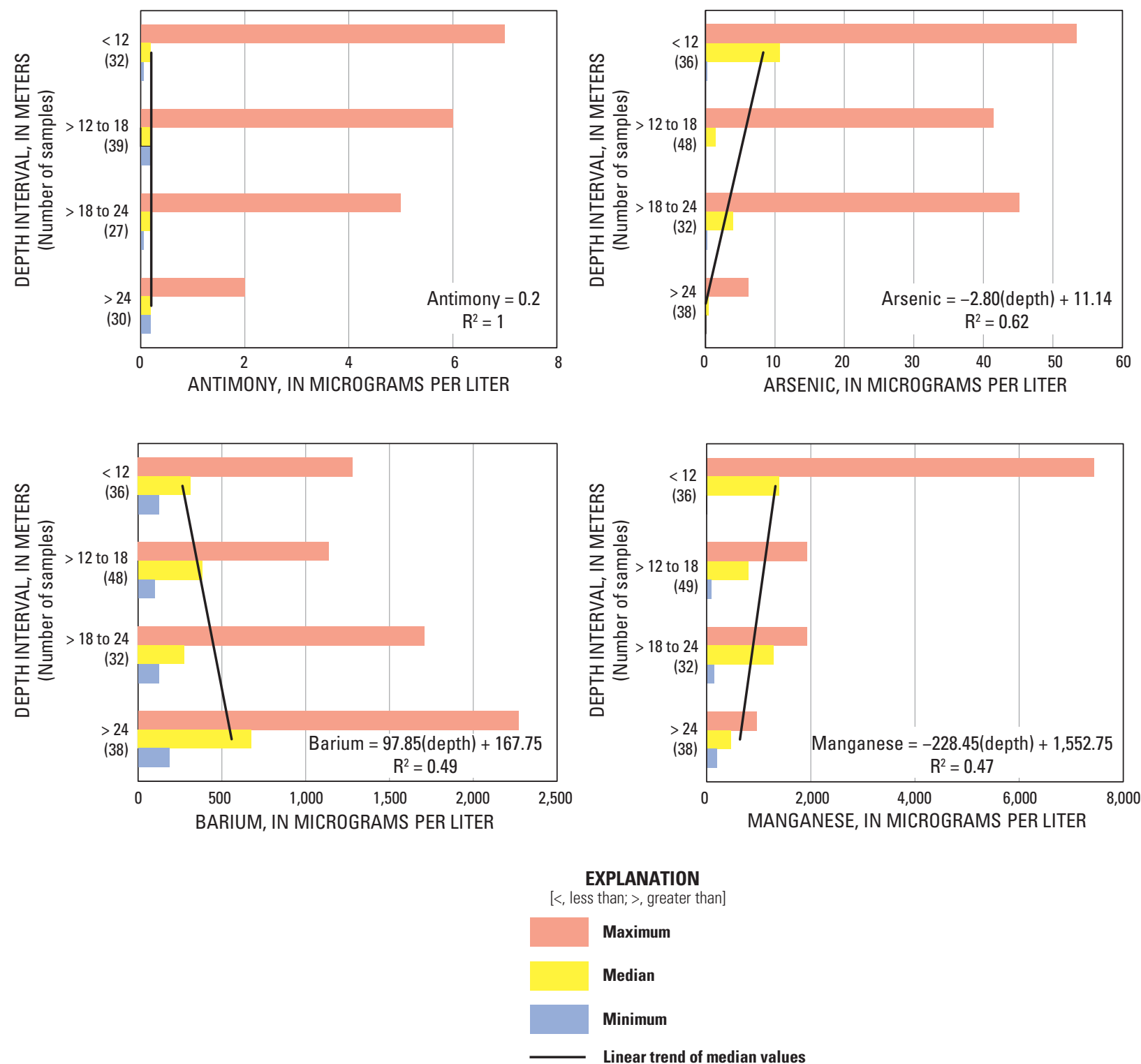

Figure 40. Antimony, arsenic, barium, and manganese concentrations and linear trend of median concentrations for water samples from monitoring wells grouped by depth interval. 
$<12$-m depth interval and smallest in the $>24$-m depth interval, and varied with depth similar to the maximum concentration. Maximum, median, and minimum concentrations of barium increased with depth. Maximum and median concentrations of manganese tended to decrease with depth. However, minimum concentrations of manganese increased slightly with depth.

Instead of grouping by depth interval, selected major ions, iron, and trace elements were grouped according to well nest because little variability with depth was evident for median concentrations, and most analyses of major ions and trace elements were from one well in each well nest. Median concentrations of selected major ions and trace elements in samples for wells grouped by well nest are shown in figure 41. Largest median concentrations of calcium, magnesium, sodium, chloride, sulfate, and arsenic were from wells south of the Missouri River. The largest median concentration of manganese was from a well north of the Missouri River, and large median concentrations of bicarbonate and iron were throughout the well field.

Boxplots of major ions, iron, and selected trace elements and linear trend of median concentrations for samples from monitoring wells grouped by year are shown in figure 42 . The linear trend of median concentrations of sodium and antimony decreased slightly from 1998 to 2008; the linear trend of median concentrations for all other major ions, iron, and selected trace elements increased slightly per year. The coefficients of determination of the linear regression for all major ions, iron, and selected trace elements shown in figure 42 were small indicating that a small variation of these constituents was related to time.

\section{Wastewater Indicator Compounds}

Detections of wastewater indicator compounds in water samples are listed in table 19. The most frequently detected wastewater indicator compounds were $N, N$-diethyl-meta-toluamide (DEET) (19 detections), phenol (16 detections), and caffeine and metolachlor ( 6 detections each). Detections of DEET and phenol were also present in sample blanks. The greatest number of detections occurred in IND with 21 detections between 2000 and 2008. The greatest number of detections for a single sample (June 15, 2004) was in IND (10 detections).

Wastewater indicator compound detections in samples for wells grouped by well nest are shown in figure 43 . The greatest number of wastewater indicator detections in samples from monitoring well nests occurred in well nests 3 ( 8 detections), 1 and 19 (7 detections each), and 6 (5 detections).

Percentage of wells sampled with one or more detections of wastewater indicator compounds for samples grouped by year are shown in figure 44. Wastewater indicator compounds were detected in water samples in at least one well every year. All samples from wells in 2003 (2 wells) and 2005 (9 wells)

had detections of at least one wastewater indicator compound, and detections were greater than 50 percent for all years except 2006.

\section{Fuel Compounds and Total Benzene, Toluene, Ethylbenzene, and Xylene (BTEX)}

Detections of fuel compounds in water samples are listed in table 20 and in table 21, at the back of this report. The most frequently detected fuel compounds were toluene (15 detections) and benzene (5 detections). Total BTEX is a total analysis of the fuel compounds benzene, toluene, ethylbenzene, and xylene and was done only by enzyme-linked immunosorbent assay (ELISA) (table 21). Individual fuel compounds also were analyzed (table 9) to determine the composition of the BTEX. Total BTEX was detected in 19 samples from 16 monitoring wells and combined well-field sample IND (22 of 217 samples; 10 percent), and concentrations ranged from 0.02 to $0.33 \mathrm{mg} / \mathrm{L}$. There is no MCL for total BTEX (table 9). The largest total BTEX detection of $0.33 \mathrm{mg} / \mathrm{L}(330 \mathrm{ug} / \mathrm{L})$ in water sampled from IND on May 27, 1999, is less than the MCL of toluene $(1,000 \mu \mathrm{g} / \mathrm{L})$, ethyl benzene $(700 \mu \mathrm{g} / \mathrm{L})$, or xylene $(10,000 \mu \mathrm{g} / \mathrm{L})$, but greater than the MCL for benzene $(5 \mu \mathrm{g} / \mathrm{L})$. The smallest BTEX detection was $0.02 \mathrm{mg} / \mathrm{L}(20 \mathrm{ug} / \mathrm{L})$ in a sample from monitoring well 4C on July 16, 2008.

Fuel compounds and BTEX detections in samples for wells grouped by well nest are shown in figure 45 . The greatest number of fuel compound detections were for samples from well nests 28 ( 7 detections) and 29 (5 detections).

Number of samples, detections, and non-detections of fuel compounds and total BTEX in samples grouped by year are shown in figure 46. All samples from wells in 2002 (3 samples) had detections of fuel compounds. Fuel compounds were not detected in 2000, 2003, 2005, and 2007. However, BTEX was detected in 1999, 2005, 2006, 2007, and 2008. Largest number of detections of fuel compounds were in 2008 (8 samples) and of total BTEX were in 2006 (7 samples). No temporal trend is evident for detections of fuel compounds from 1998 to 2008 or total BTEX from 1999 to 2008.

\section{Alachlor and Atrazine}

Results of analyses for alachlor and atrazine in water samples are listed in table 21 at the back of this report. Alachlor was detected in 22 samples from monitoring wells and in IND (50 of 442 samples; 11 percent), and concentrations were less than the MCL for alachlor $(2 \mu \mathrm{g} / \mathrm{L})$ in all samples. Atrazine was detected in 38 samples from monitoring wells and in IND (67 of 370 samples; 18 percent), and concentrations ranged from 0.05 to $7.51 \mu \mathrm{g} / \mathrm{L}$. The MCL for atrazine $(3 \mu \mathrm{g} / \mathrm{L})$ was exceeded in one sample from monitoring well $16 \mathrm{~b}(7.5 \mu \mathrm{g} / \mathrm{L})$ on June 21,1999 . Alachlor and atrazine concentrations in samples from all monitoring wells are shown in figure 47.

The distribution of alachlor and atrazine in groundwater from samples from monitoring wells grouped by well nest are shown in figure 48. The largest alachlor percentage detections occurred in samples from monitoring well nest 15 ( $>60$ to 70 percent). All other samples from monitoring well nests had 


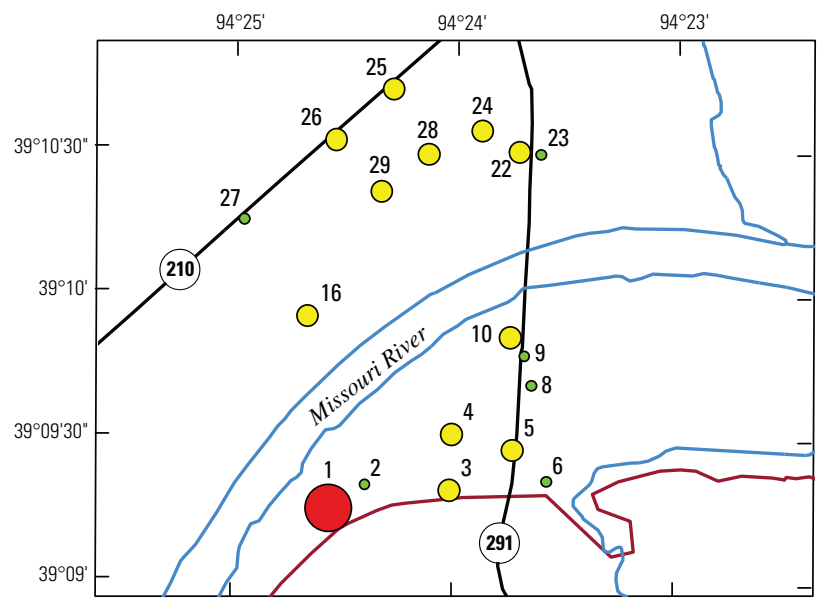

\section{EXPLANATION}

[>, greater than]

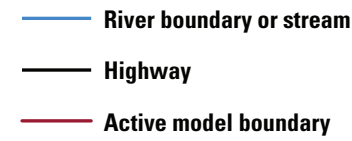

Active model boundary

Monitoring well nest, identifier, and calcium, in milligrams per liter

3 ○ 122 to 150

$>150$ to 200

$>200$ to 250

$>250$ to 300

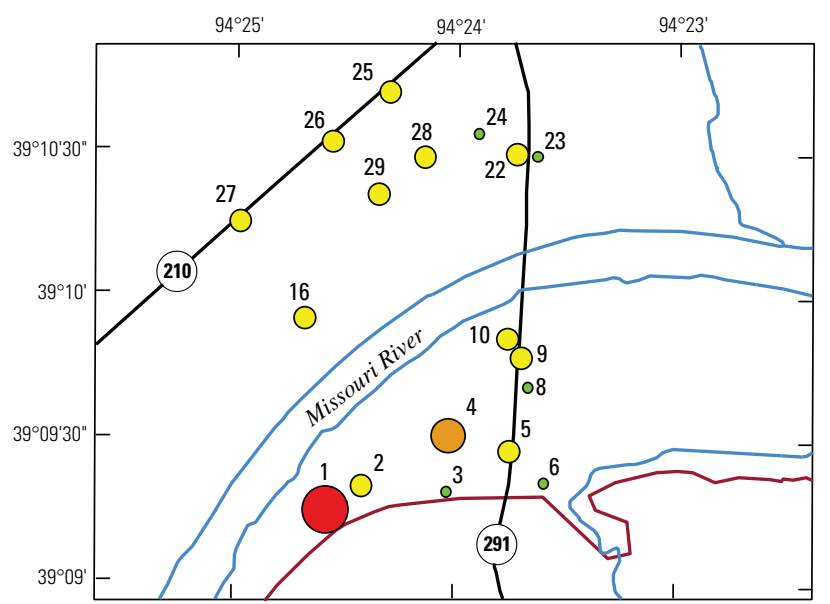

Monitoring well nest, identifier, and magnesium, in milligrams per liter

3 ○ 22 to 30

$\bigcirc>30$ to 45

$>45$ to 60

$>60$ to 75

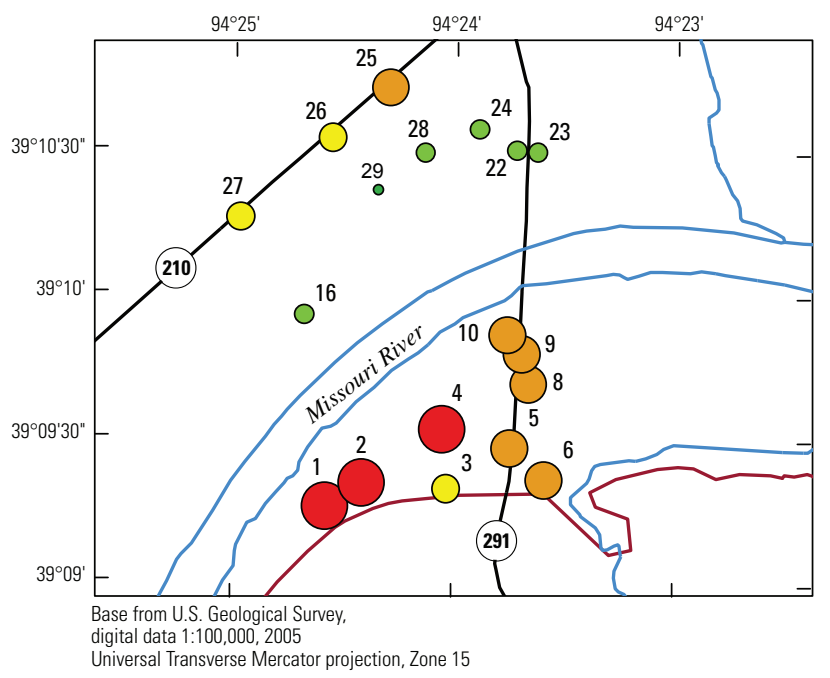

Monitoring well nest, identifier, and sodium, in milligrams per liter
3 ○ 8 to 10
○> $>10$ to 20
$>20$ to 30
$>30$ to 40
$>40$ to 70

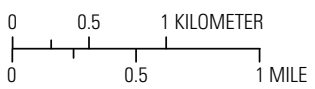

Figure 41. Median concentrations of selected major ions and trace elements for water samples from monitoring wells grouped by well nest. 


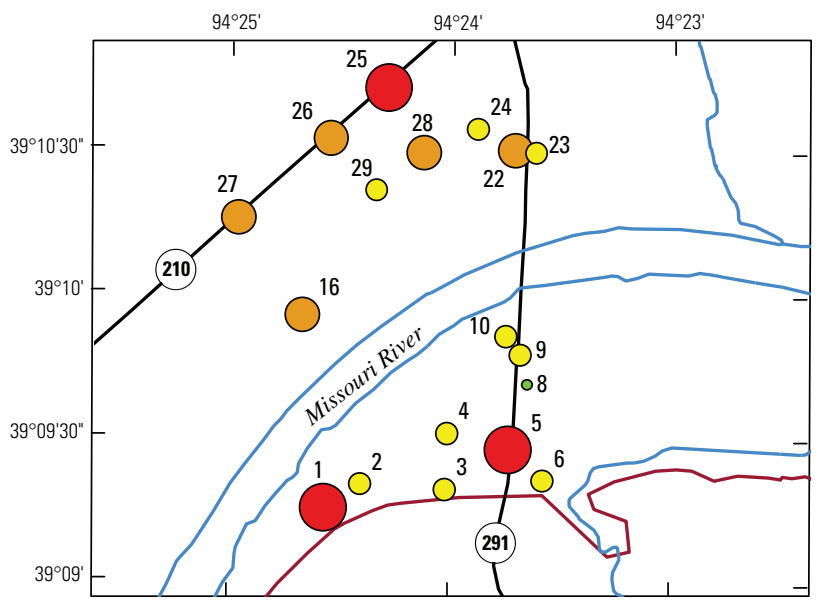

\section{EXPLANATION}

[>, greater than]

\section{River boundary or stream \\ - Highway \\ Active model boundary}

Monitoring well nest, identifier, and bicarbonate, in milligrams per liter

3 。 414 to 450

$\bigcirc>450$ to 600

$\bigcirc>600$ to 750

$>750$ to 900

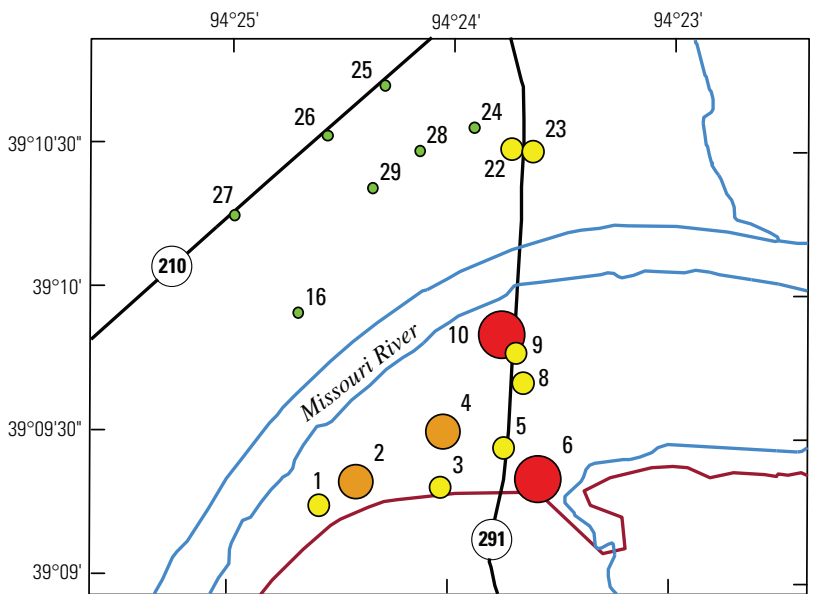

Monitoring well nest, identifier, and chloride in milligrams per liter

3 。 4 to 10

$\bigcirc>10$ to 20

$>20$ to 30

$>30$ to 50

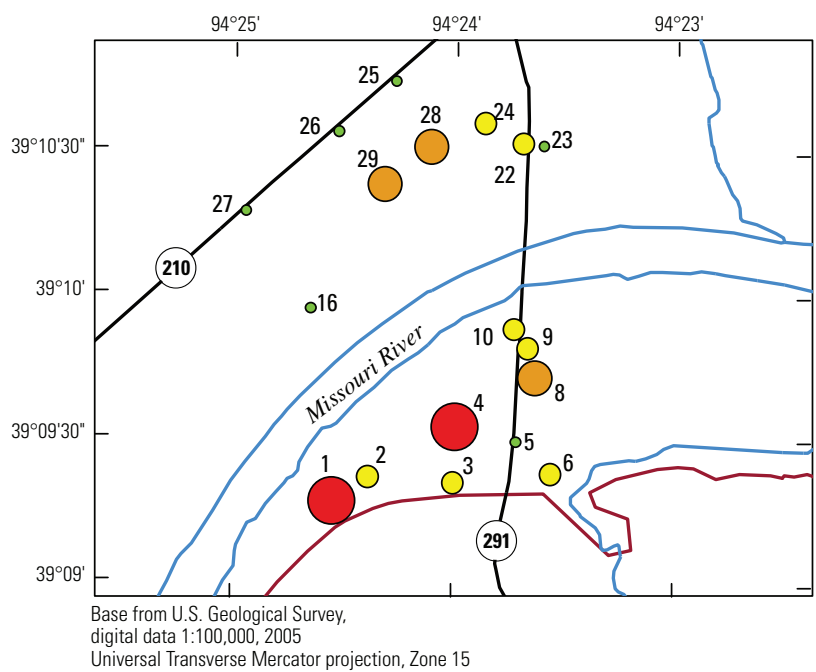

Monitoring well nest, identifier, and sulfate, in milligrams per liter

3 。 3 to 50

$\bigcirc>50$ to 100

$\bigcirc>100$ to 200

$>200$ to 300

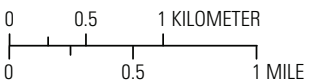

Figure 41. Median concentrations of selected major ions and trace elements for water samples from monitoring wells grouped by well nest.-Continued 


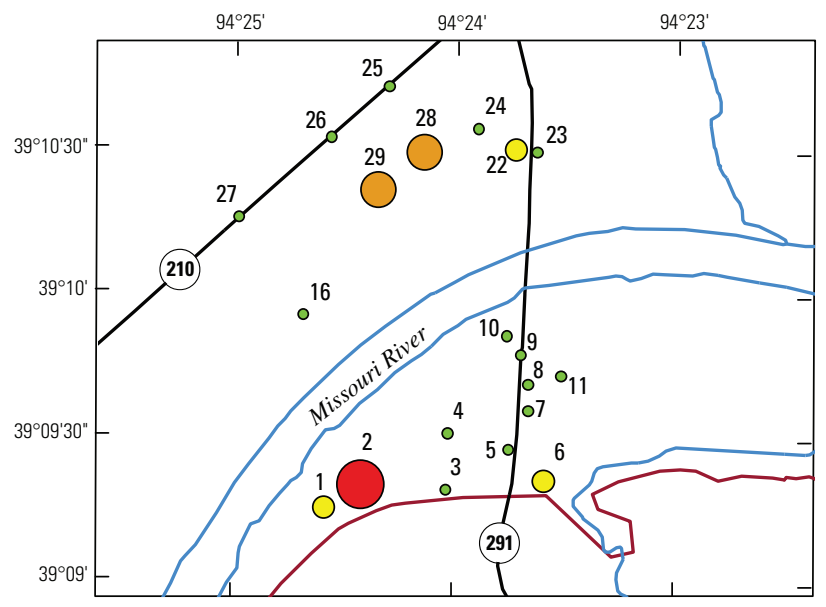

\section{EXPLANATION}

[>, greater than]

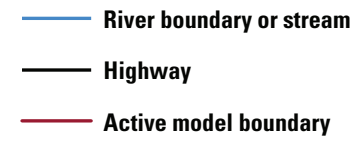

Active model boundary

Monitoring well nest, identifier, and arsenic, in micrograms per liter

$3 \circ 0.2$ to 5

$>5$ to 10

$>10$ to 20

$>20-30$

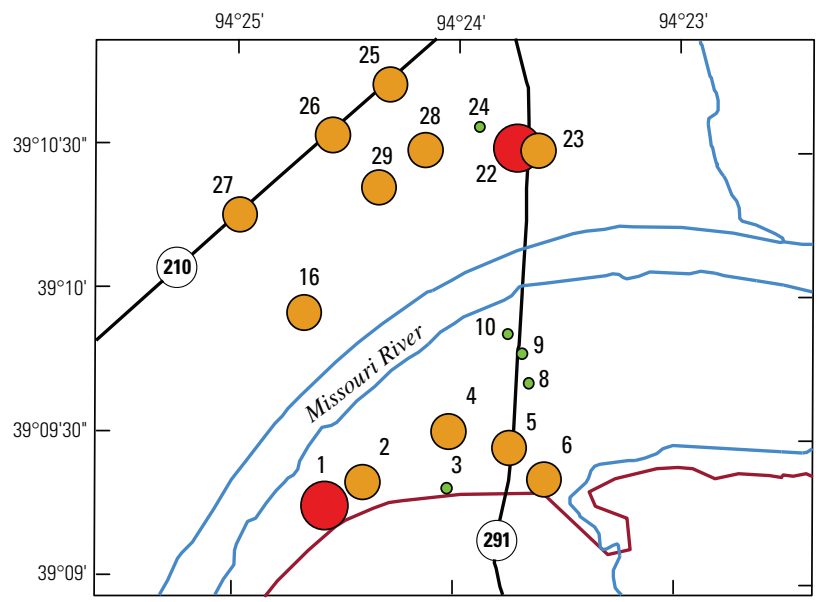

Monitoring well nest, identifier, and iron, in micrograms per liter

3 ○ 0.48 to 5

$>>5$ to 10

$>10$ to 20

$>20$ to 40

Monitoring well nest, identifier, and manganese, in micrograms per liter

3 ○ 249 to 500

$>>500$ to 1000

$>1,000$ to 2,000

$>2,000$ to 4,000
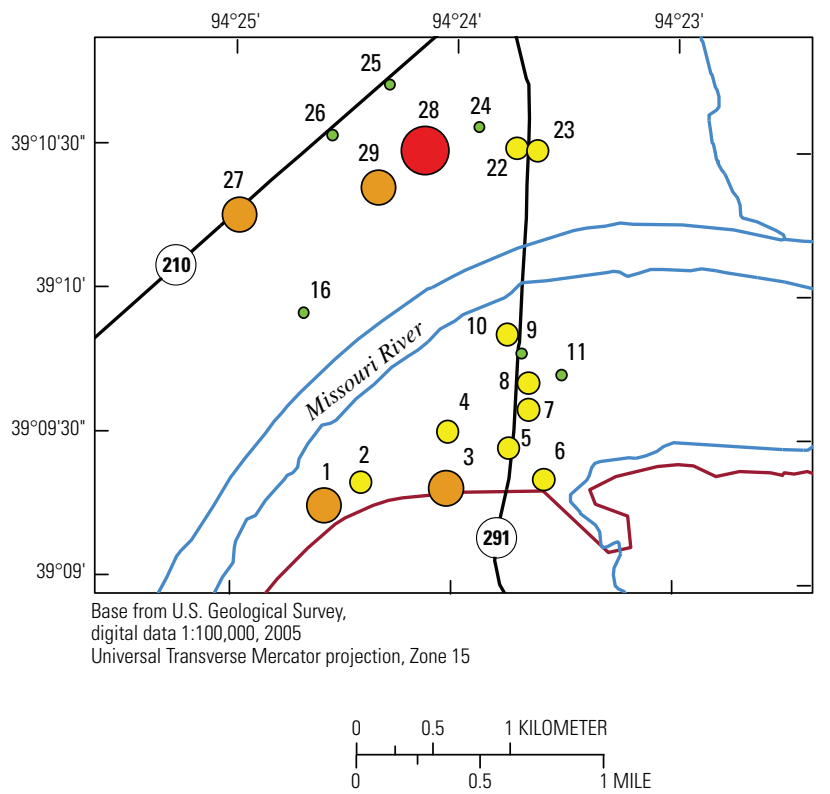

Figure 41. Median concentrations of selected major ions and trace elements for water samples from monitoring wells grouped by well nest.-Continued 

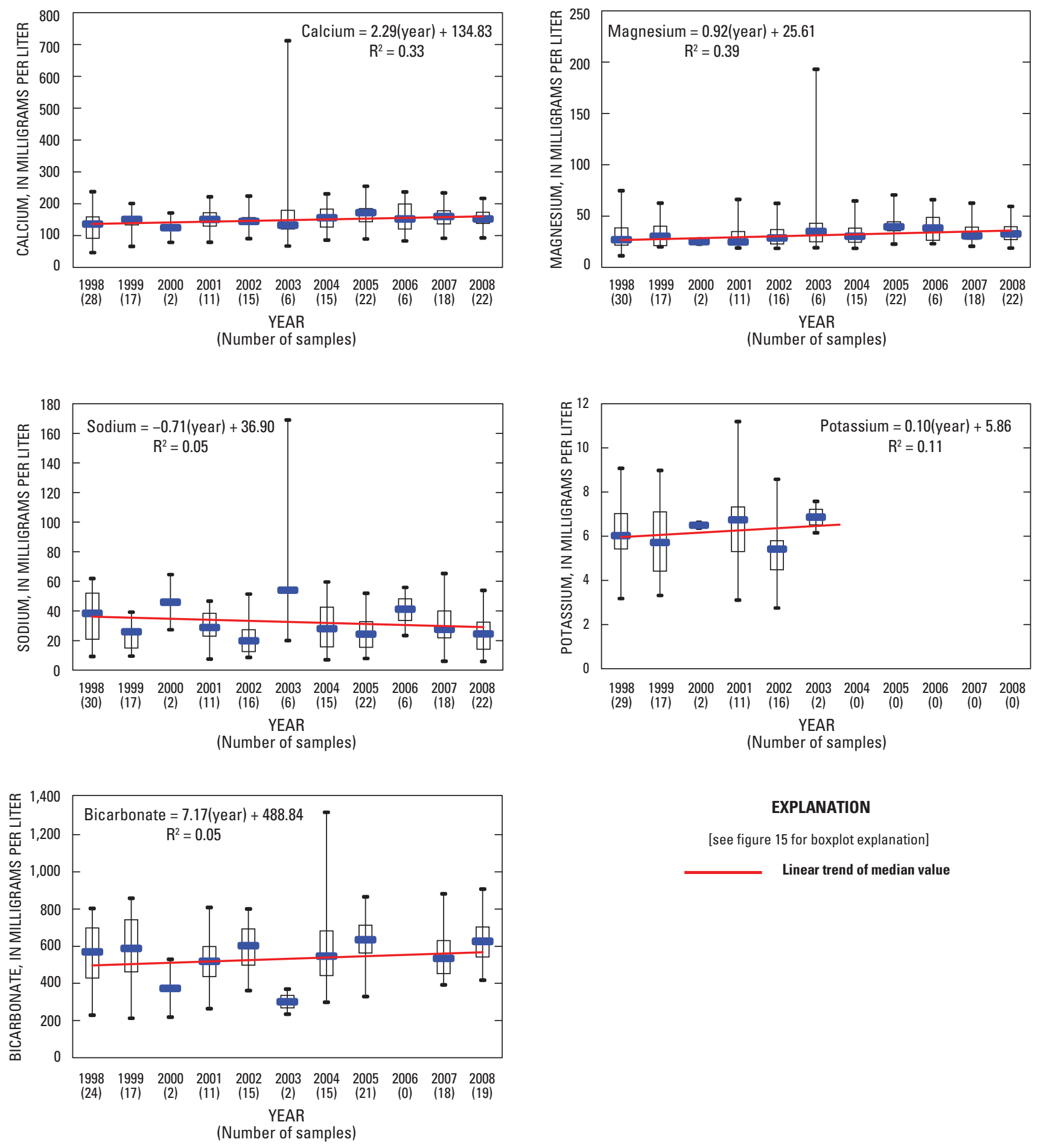

\section{EXPLANATION}

[see figure 15 for boxplot explanation]

Linear trend of median value

Figure 42. Boxplots of dissolved major ions iron and linear trend of median concentrations for water samples from all monitoring wells grouped by year. 

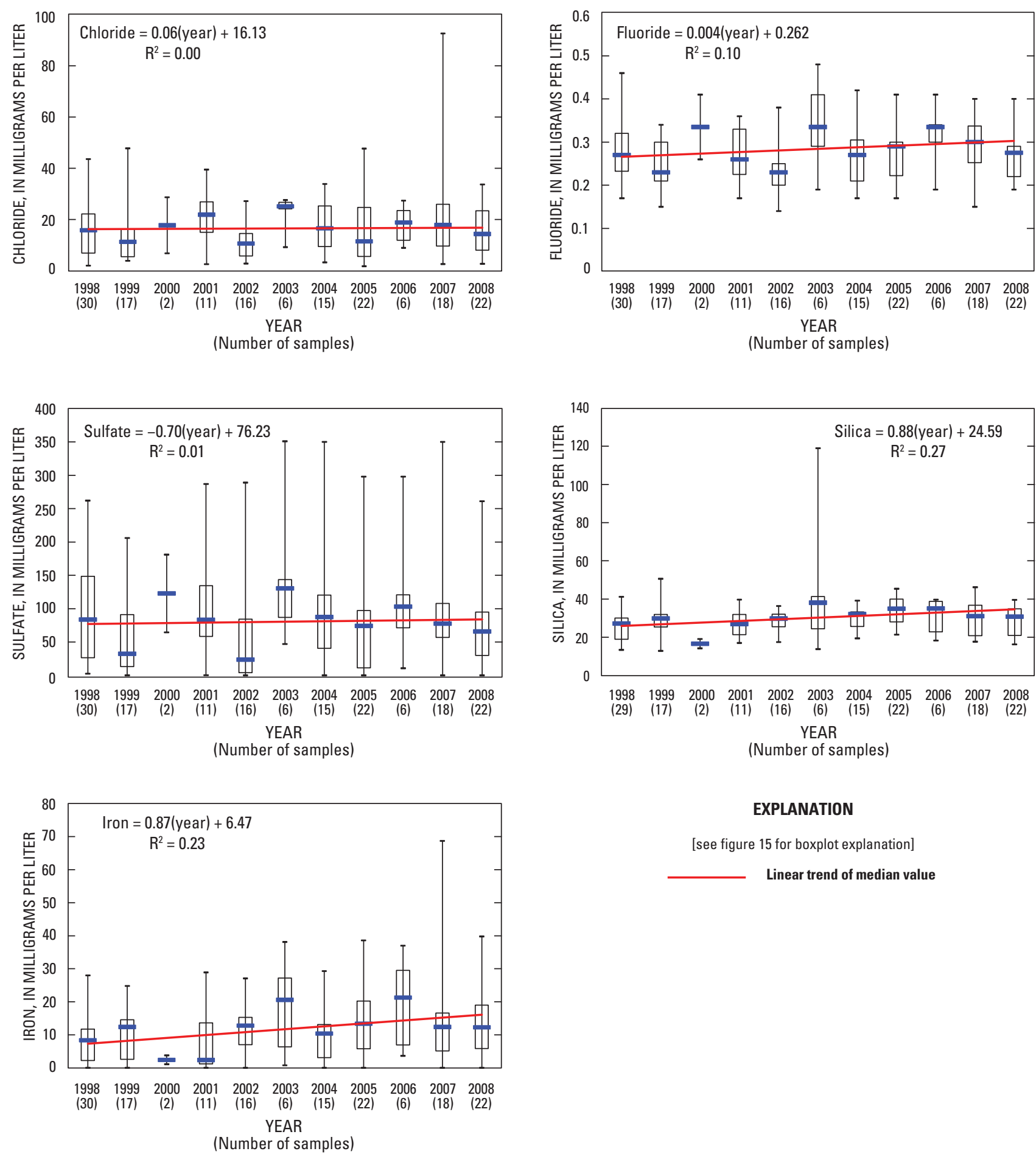

EXPLANATION

[see figure 15 for boxplot explanation]

Linear trend of median value

Figure 42. Boxplots of dissolved major ions iron and linear trend of median concentrations for water samples from all monitoring wells grouped by year.-Continued 
Table 19. Detections of wastewater indicator compounds in water samples from monitoring wells.

$[\mu \mathrm{g} / \mathrm{L}$, micrograms per liter; -, below detection limit; E, estimated; M, presence detected but not quantified; IND, combined well-field sample, HHCB, Hexa-hydro-hexa-methyl cyclo-penta-benzo-pyran; DEET, N,N-diethyl-meta-toluamide]

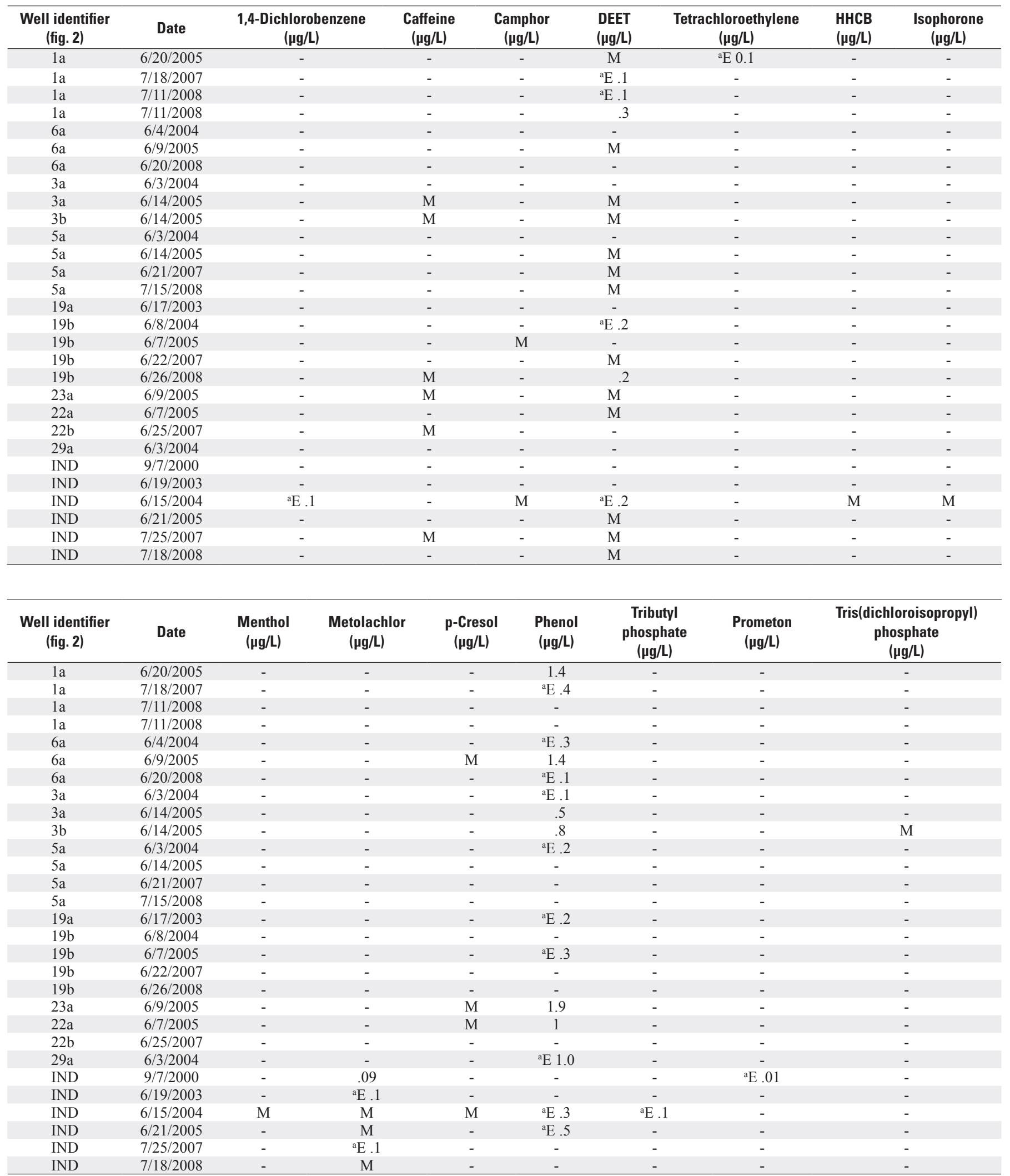

${ }^{a}$ Estimated values are concentrations measured between the laboratory reporting level and the long-term method detection level (Childress and others, 1999). 


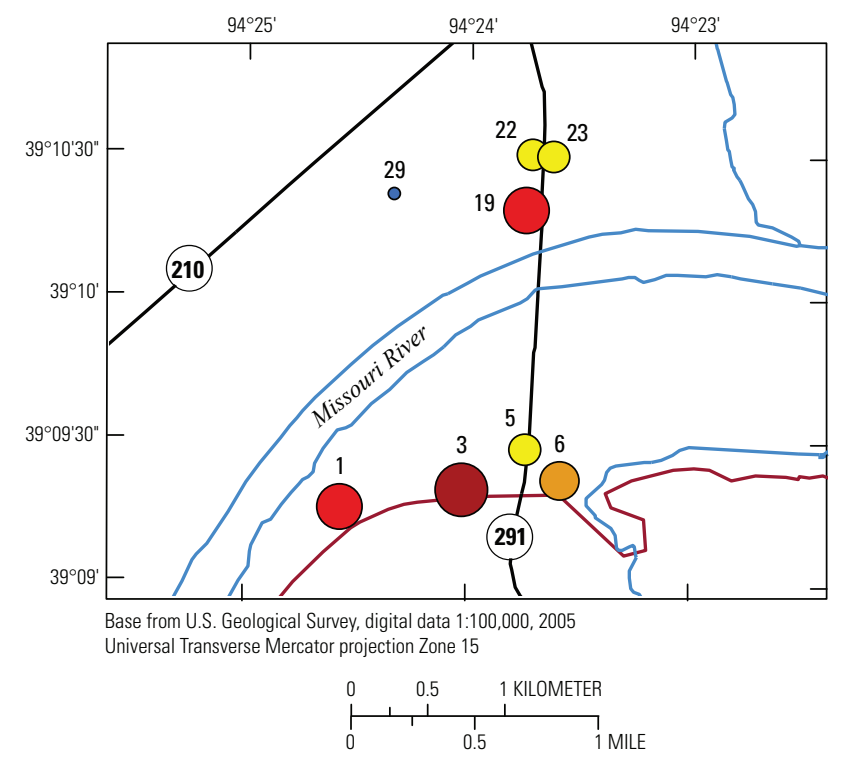

EXPLANATION

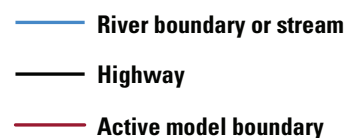

Monitoring well nest, identifier, and number of wastewater indicator detections

$3 \circ 1$

○ 4

5

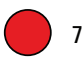

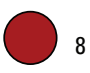

Figure 43. Wastewater indicator compound detections in water samples from monitoring wells grouped by well nest.

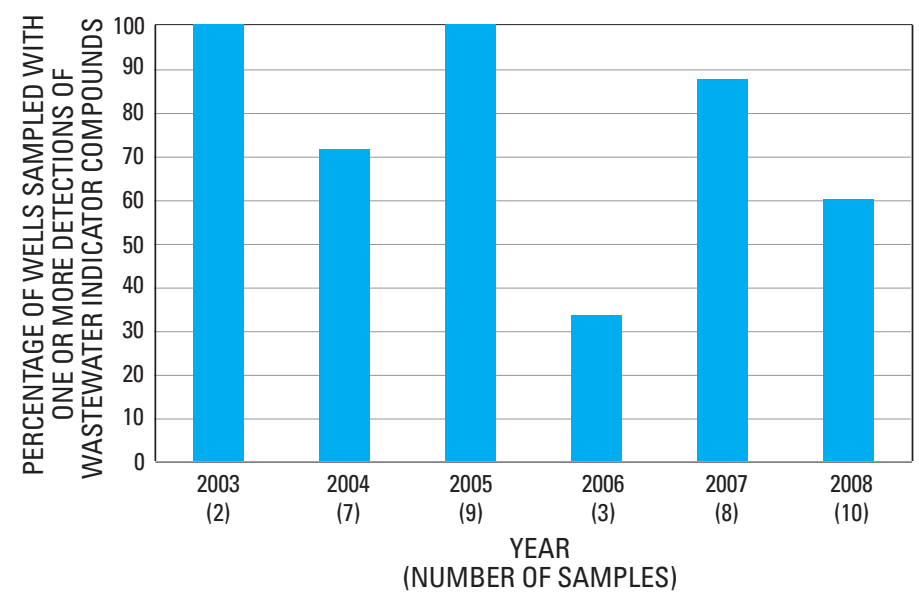

Figure 44. Percentage of wells sampled with one or more detections of wastewater indicator compounds for water samples from monitoring wells grouped by year. 
Table 20. Detections of fuel compounds and total BTEX (benzene, toluene, ethylbenzene, and xylene) in water samples from monitoring wells.

$[\mu \mathrm{g} / \mathrm{L}$, micrograms per liter; BTEX, benzene, toluene, ethylbenzene, and xylene; $\mathrm{mg} / \mathrm{L}$, milligrams per liter; a,b,c in identifier indicates relative depth of the well in each nest from "a" the deepest to "c" the shallowest. For well nest 4, 4a is deepest, 4c is intermediate, and 4b is shallowest; -, below laboratory reporting level; ns, no sample; IND, combined well-field sample]

\begin{tabular}{|c|c|c|c|c|c|c|}
\hline $\begin{array}{c}\text { Well identifier } \\
\text { (fig. 2) }\end{array}$ & Date & $\begin{array}{c}\text { Benzene } \\
(\mu \mathrm{g} / \mathrm{L})\end{array}$ & $\begin{array}{c}\text { Ethylbenzene } \\
(\mu \mathrm{g} / \mathrm{L})\end{array}$ & $\begin{array}{c}\text { Toluene } \\
\text { ( } \mu \mathrm{g} / \mathrm{L})\end{array}$ & $\begin{array}{c}\text { Xylene } \\
\text { ( } \mu \mathrm{g} / \mathrm{L})\end{array}$ & $\begin{array}{c}\text { Total aBTEX } \\
\text { (mg/L) }\end{array}$ \\
\hline \multirow[t]{2}{*}{$1 \mathrm{a}$} & $6 / 20 / 2006$ & - & - & - & - & 0.08 \\
\hline & $7 / 11 / 2008$ & - & - & .1 & - & - \\
\hline \multirow[t]{2}{*}{$1 b$} & $6 / 20 / 2006$ & - & - & - & - & .18 \\
\hline & $7 / 11 / 2008$ & - & - & .2 & - & - \\
\hline \multirow[t]{3}{*}{$2 \mathrm{a}$} & $6 / 20 / 2006$ & - & - & .2 & - & - \\
\hline & $6 / 21 / 2006$ & ns & ns & ns & - & .03 \\
\hline & $7 / 8 / 2008$ & - & - & .1 & - & - \\
\hline \multirow[t]{2}{*}{$2 b$} & $6 / 20 / 2006$ & ns & ns & ns & - & .15 \\
\hline & $6 / 21 / 2006$ & - & - & .2 & - & ns \\
\hline $4 b$ & $7 / 16 / 2008$ & ns & ns & ns & - & .05 \\
\hline $4 c$ & $7 / 16 / 2008$ & ns & ns & ns & - & .02 \\
\hline $6 a$ & $6 / 9 / 2005$ & ns & ns & ns & - & .03 \\
\hline $8 b$ & $6 / 21 / 2006$ & ns & ns & ns & - & .10 \\
\hline $11 \mathrm{a}$ & 7/22/1998 & - & .2 & 1.1 & - & ns \\
\hline $16 \mathrm{a}$ & $5 / 5 / 1999$ & ns & ns & ns & - & .03 \\
\hline \multirow[t]{3}{*}{$21 \mathrm{c}$} & $6 / 8 / 2005$ & ns & ns & ns & - & .04 \\
\hline & $6 / 22 / 2006$ & ns & ns & ns & - & .15 \\
\hline & $7 / 25 / 2007$ & ns & ns & ns & - & .10 \\
\hline $23 c$ & $6 / 25 / 2007$ & ns & ns & ns & - & .05 \\
\hline $24 c$ & $6 / 25 / 2007$ & ns & ns & ns & - & .08 \\
\hline \multirow[t]{2}{*}{$26 b$} & $6 / 8 / 2005$ & ns & ns & ns & - & .04 \\
\hline & $7 / 17 / 2007$ & ns & ns & ns & - & .11 \\
\hline $27 \mathrm{a}$ & $6 / 8 / 2005$ & ns & ns & ns & - & .05 \\
\hline $27 b$ & 5/14/1999 & ns & ns & ns & - & .27 \\
\hline \multirow[t]{3}{*}{$28 \mathrm{a}$} & $9 / 4 / 2002$ & - & - & .5 & - & - \\
\hline & $6 / 23 / 2006$ & - & - & .2 & - & - \\
\hline & $7 / 17 / 2008$ & .5 & - & .5 & - & - \\
\hline \multirow[t]{2}{*}{$28 b$} & $9 / 4 / 2002$ & - & - & .2 & - & - \\
\hline & $7 / 17 / 2008$ & .5 & - & .5 & - & - \\
\hline \multirow[t]{2}{*}{$29 a$} & $9 / 4 / 2002$ & - & - & .3 & - & - \\
\hline & $7 / 17 / 2008$ & .2 & - & .4 & - & - \\
\hline \multirow[t]{2}{*}{$29 b$} & $7 / 24 / 2007$ & - & - & - & - & .06 \\
\hline & 7/17/2008 & .3 & - & .4 & - & - \\
\hline \multirow[t]{3}{*}{ IND } & 5/27/1999 & ns & ns & ns & - & .33 \\
\hline & $6 / 26 / 2006$ & ns & ns & ns & - & .10 \\
\hline & $7 / 25 / 2007$ & ns & ns & ns & - & .06 \\
\hline
\end{tabular}

${ }^{a}$ Total BTEX is a total analysis of the fuel compounds benzene, toluene, ethylbenzene, and xylene only by enzyme-linked immunosorbent assay. 

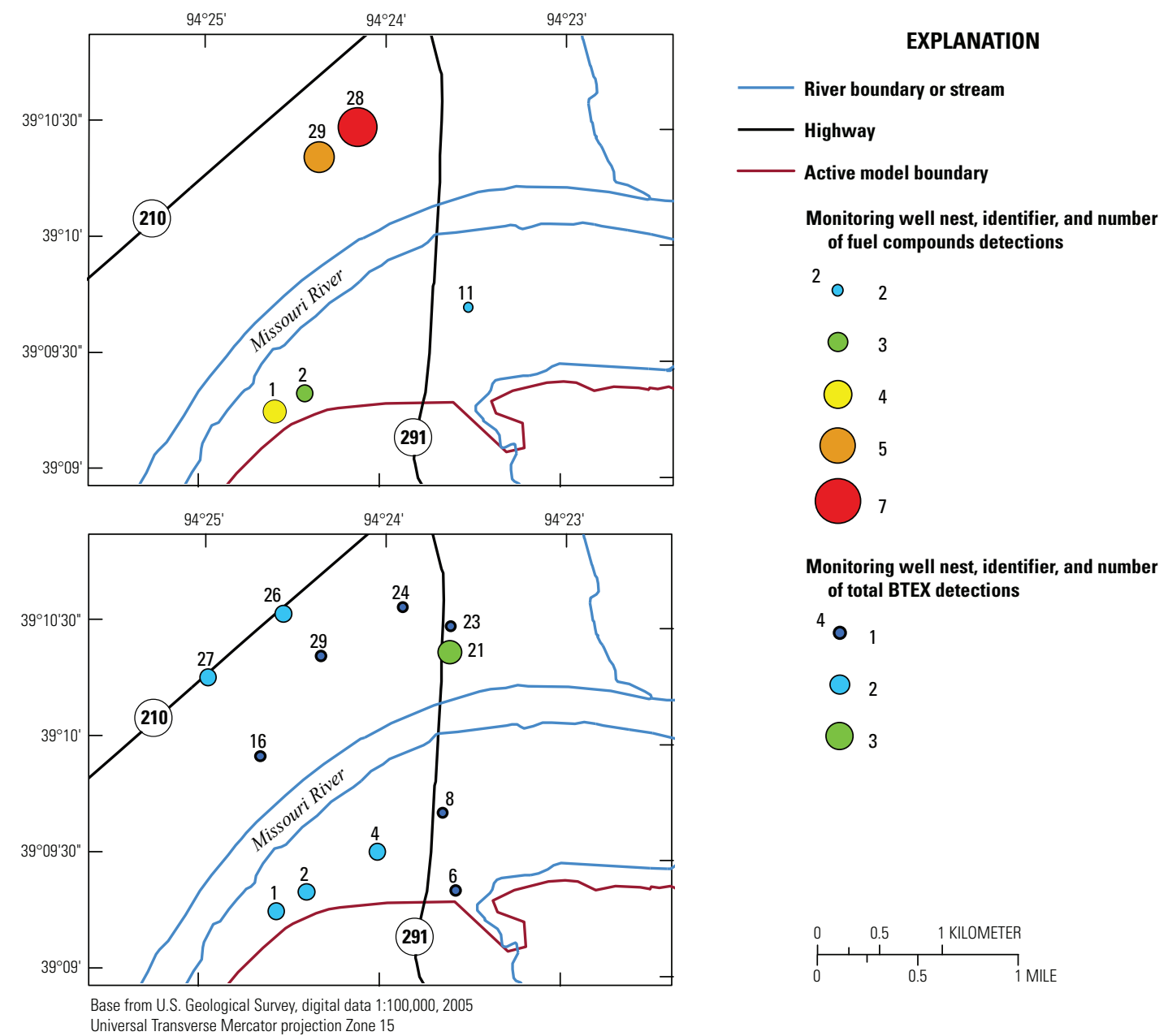
Monitoring well nest, identifier, and number
of total BTEX detections

4 ○ 1

$\bigcirc 2$

$\bigcirc 3$

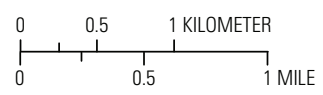

Figure 45. Detections of fuel compounds and total BTEX (benzene, ethylbenzene, toluene, and xylene) in water samples for monitoring wells grouped by well nest.

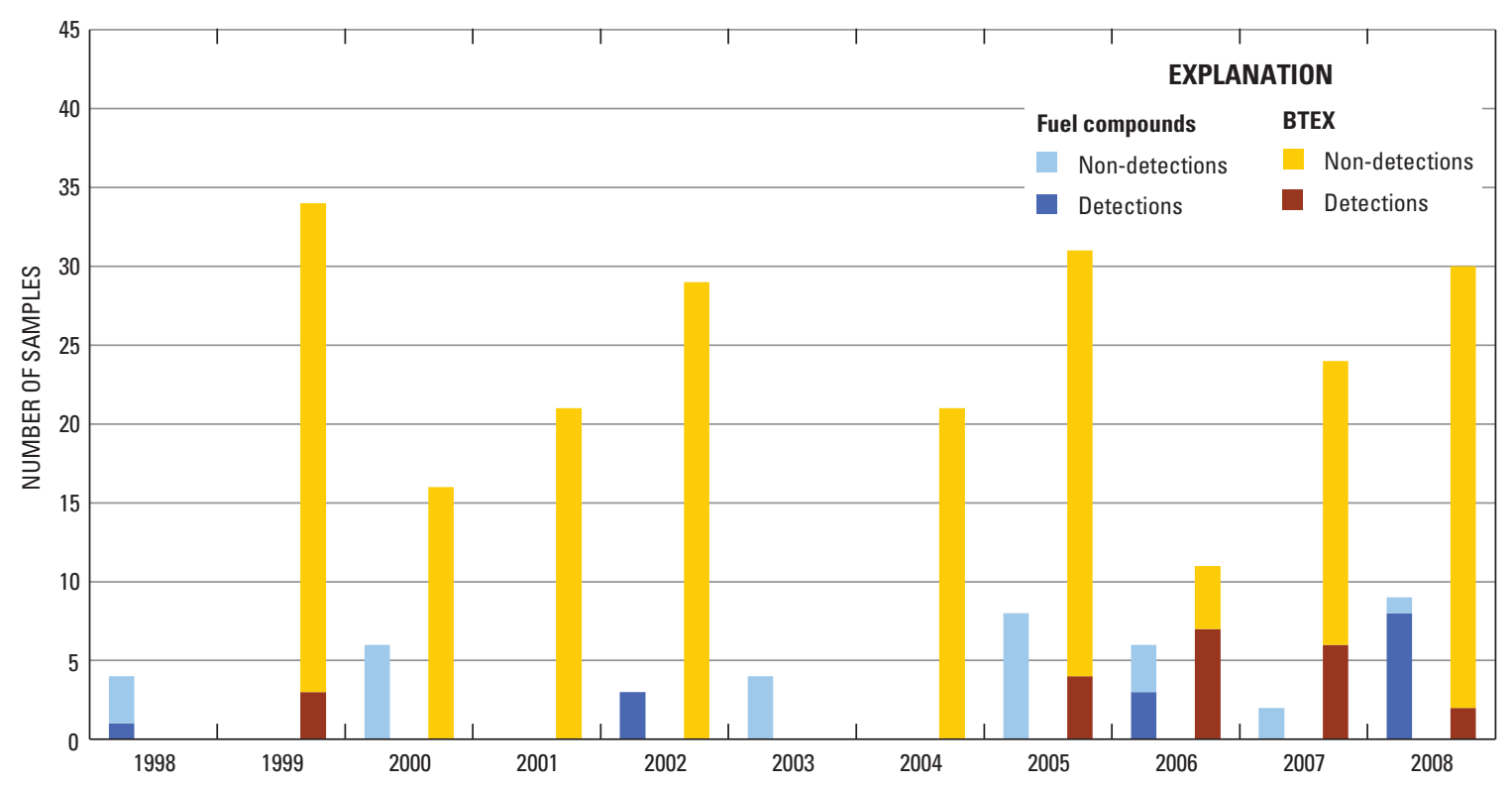

Figure 46. Number of samples with detections and non-detections of fuel compounds and total BTEX (benzene, toluene, ethylbenzene, and xylene) for water samples from monitoring wells grouped by year. 


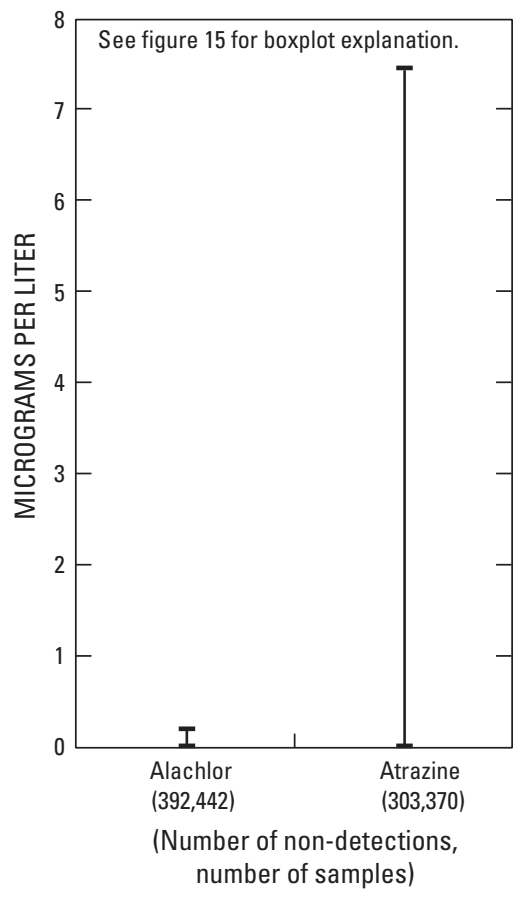

Figure 47. Boxplots for alachlor and atrazine for water samples from all monitoring wells.

fewer than 30 percentage detections. The largest atrazine percentage detections also occurred in samples from monitoring well nest 15 (> 50 to 60 percent), and all other samples from monitoring well nests had fewer than 30 percentage detections.

Percent detections for alachlor and atrazine for all water samples grouped by year are shown in figure 49 . Alachlor was detected in all years except 2003, 2004, and 2008. Largest percent detections for alachlor were for 1999 (42 percent; 11 detections) and 2006 ( 25 percent; 3 detections), although 2005 and 2007 had four detections each (14 and 15 percent, respectively). Atrazine was detected in 1999, 2000, 2003, 2005 , and 2007. The most yearly detections for atrazine occurred in 1999 (77 percent; 20 detections). No temporal trend is evident for frequency of detection of alachlor or atrazine from 1999 to 2008.

\section{Groundwater Flow and Quality}

The CRA to the Independence well field includes both the land surface and the Missouri River streambed. The quality of water recharging the aquifer from rainfall and induced from the Missouri River into the aquifer by well withdrawals affects the water quality in the aquifer near the Independence well field. Industrial, commercial, and agricultural activities can affect groundwater quality as can the interaction of groundwater with aquifer material as it travels through the aquifer. The path that water has travelled through the aquifer to the Independence well field changes over time because of fluctuating river stage, intermittent recharge, and pumping changes caused by the addition of new supply wells to the well field or pumping patterns. Because of the dynamic nature and the complex history of groundwater flow within the aquifer, analysis of water-quality results needs to be within the framework of groundwater flow and travel time.

Monitoring wells 1a, 1b, 2a, 2b, 4a, 4c, 10c, 12b, 13b, 16b, 17a, and 17b (fig. 32) are located near agricultural land (fig. 23) and had samples with median concentrations of total inorganic nitrogen larger than $1 \mathrm{mg} / \mathrm{L}$. Although well pumpage and distribution have changed substantially north of the river over time, well withdrawals have remained relatively stable from 1997 to 2008 south of the river. A comparison of the CRAs for each of the monitoring wells south of the Missouri River (fig. 21) with samples from monitoring wells that have median concentrations of total inorganic nitrogen larger than $1 \mathrm{mg} / \mathrm{L}$ indicates their CRAs intersect the Missouri River (1a, 1b, 2a, 2b, 12b, 13b), or both agricultural land and the Missouri River (4a and 10c). The CRA for monitoring well $4 \mathrm{c}$ is most likely agricultural land near the monitoring well, but the model could not calculate a CRA because simulated drawdown near the well field caused model cells to dry out for the steady-state simulation, and the screened interval for monitoring well $4 \mathrm{c}$ is in the zone of dry cells. The larger total inorganic nitrogen concentrations in these samples from monitoring wells may indicate that agricultural land practices are the source of nitrogen to groundwater. However, other samples from monitoring wells south of the river with CRAs in agricultural land or the river do not have high median concentrations of total inorganic nitrogen. Differences in total inorganic nitrogen between these samples from monitoring wells and those with larger total inorganic nitrogen concentrations may be caused by different agricultural land practices over time, other sources of inorganic nitrogen, or changes in the location of the CRA over time.

Largest median values of specific conductance; total inorganic nitrogen; dissolved calcium, magnesium, sodium, iron, arsenic, manganese, bicarbonate, and sulfate; and detections of wastewater indicator compounds generally were in water samples from monitoring well nests 1, 2, 3, and 4 (figs. 24, 30, 36, and 43). CRAs for these monitoring wells, shown in figure 21, indicate that the water is induced recharge from the Missouri River and land-surface infiltration. Results of a previous investigation of changes in water quality between the Missouri River and supply wells of the Independence well field (Kelly and Rydlund, 2006) indicated a zone of higher specific conductance (between 820 and $840 \mu \mathrm{S} / \mathrm{cm}$ ) in water along the south bank of the Missouri River that coincides with parts of the CRAs of monitoring well nests 1,2,3, and 4. Specific conductance in water from the north bank of the Missouri River in August 2005 was between 740 and $760 \mu \mathrm{S} / \mathrm{cm}$. Although the specific conductance in water from the south bank of the Missouri River near the well field in August 2005 was less than the median values in groundwater for these well nests, zones of higher specific conductance were located immediately 


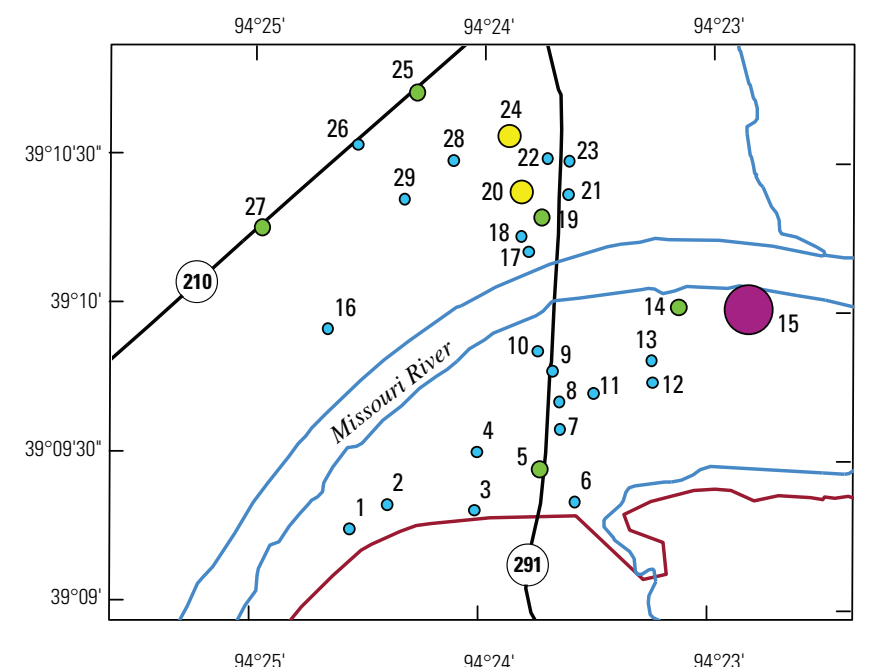

EXPLANATION
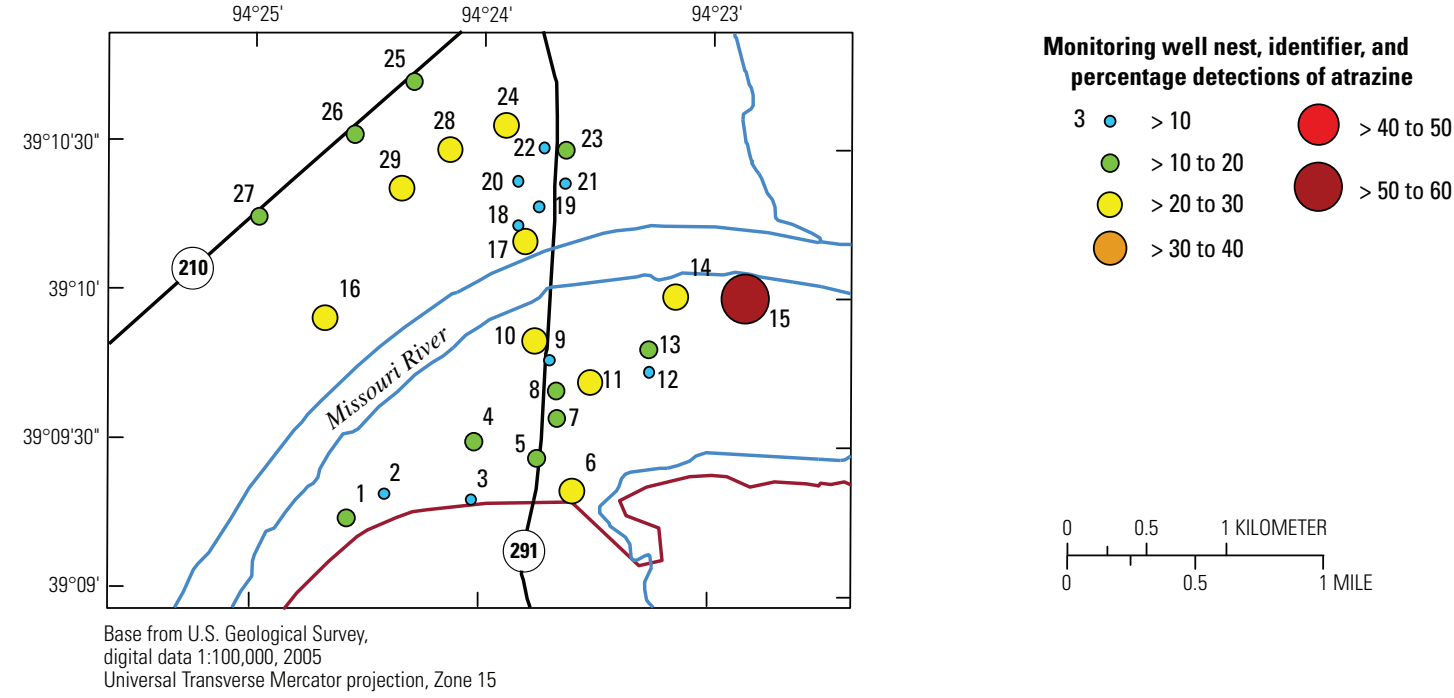

[ $>$, greater than]

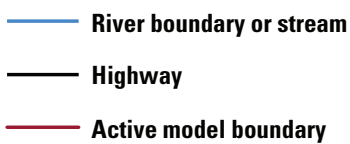

Monitoring well nest, identifier, and percentage detections of alachlor

$3 \circ>10 \bigcirc>40$ to 50

O $>10$ to 20

$\bigcirc>20$ to 30

$>30$ to 40

$>50$ to 60

$>60$ to 70

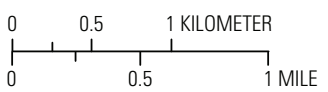

Figure 48. Percentage of detections for alachlor and atrazine in water samples from monitoring wells grouped by well nest.

upstream from the Independence well field at south-bank outfalls from wastewater treatment plants (fig. 23), the Blue River (fig. 1), and the south bank of the Missouri River near the closed oil refinery (fig. 23) (Kelly and Rydlund, 2006). The long-term presence of these south-bank outfalls and the large specific conductance indicate that the surface water at the south bank of the Missouri River near the Independence well field can be induced into the aquifer by pumping.

Large median concentrations of sodium were found in water samples from well nests 5, 8, 9, and 10, and well 6a (31 to $40 \mathrm{mg} / \mathrm{L}$ ) and chloride from well $6 \mathrm{a}$ and well nest 10 (31 to $50 \mathrm{mg} / \mathrm{L}$ ) (fig. 41). These wells are near State Highway 291 (fig. 41). CRAs for wells in nests 9 and 10 include the Missouri River and areas next to the highway. The CRAs for wells in nest 5 extend along the flood plain near Mill Creek and the CRA for well nest 6 includes the Missouri River and land surface to the east of the well field (fig. 21). The higher median concentrations of sodium and chloride in these samples from monitoring wells may be the result of road salt use on State
Highway 291 or from Mill Creek which drains the uplands south of the Independence well field.

Median concentrations of sodium and chloride in samples from monitoring wells north of the Missouri River are lower than concentrations from monitoring wells south of the Missouri River (fig. 41). Bicarbonate has higher median concentrations north of the river. These differences are most likely because of differences in groundwater travel time and less use of road salt north of the Missouri River. The CRAs for supply wells south of the river have not changed recently because pumping conditions have been relatively constant in recent years. South of the Missouri River, groundwater travel time within the CRA of each supply well (and monitoring well) is shorter than the travel time north of the river because supply wells are located closer to their sources of recharge (figs. 19 and 21). In contrast, groundwater travel times north of the Missouri River are longer, and the longest travel times are for supply wells located farther from the river. Chloride in groundwater can be associated with human activities (Hem, 1992). Smaller median concentrations of chloride in 

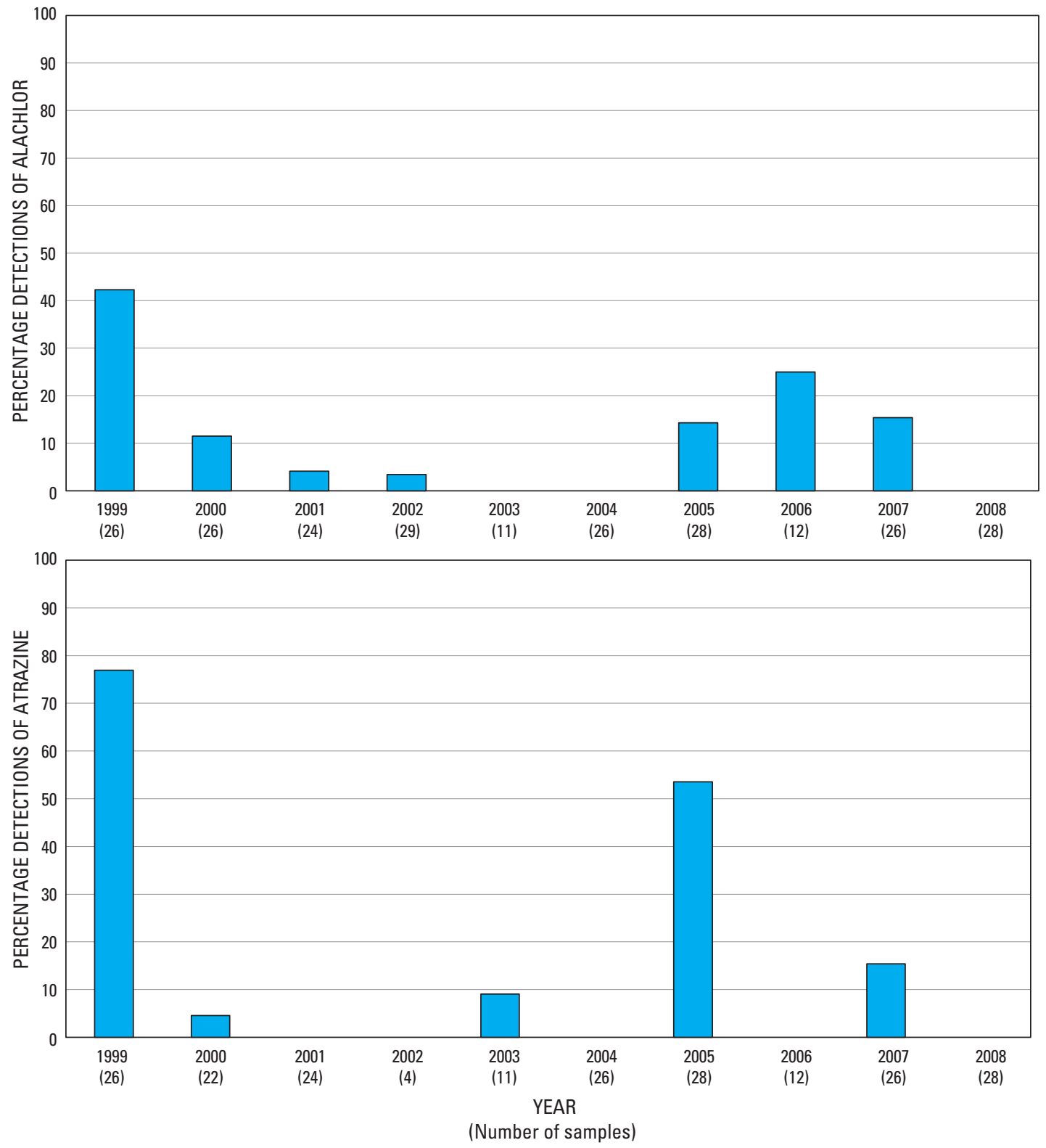

Figure 49. Percentage of detections for alachlor, and atrazine in water samples from monitoring wells grouped by year.

groundwater north of the river may indicate that this water entered the aquifer before industrial and commercial activities became widespread. Similarly, larger median concentrations of bicarbonate indicate a longer time of residence in the aquifer for this water because rainfall and surface waters are typically lower in bicarbonate than groundwater (Hem, 1992)

Median concentrations of iron (fig. 41) were large in samples from all monitoring wells and were most likely caused by the interaction between fluctuating oxidizing and reducing conditions and siderite and ferric hydroxide (Applin and Zhao, 1989; Hem, 1992). Large median concentrations of arsenic (fig. 41) in samples from monitoring well nests 1, 2,
$6,22,28$, and 29 were most likely associated with dissolution of iron and sulfide minerals and fluctuation between oxidizing and reducing conditions (Hem, 1992). Largest median concentrations for arsenic were in samples from the shallow depth interval $(<12-\mathrm{m})$ where fluctuations between oxidizing and reducing conditions occur because of fluctuating water levels.

The largest numbers of detections of wastewater indicators were in water samples from well nests $1,3,6$, and 19 (fig. 43). Many of these detections were $N, N$-diethyl-metatoluamide (DEET), which was detected in samples from all wells except 22b and 29a and may have been introduced during sampling activities. The CRAs for all monitoring wells 
in these well nests with detections of wastewater indicators, shown in figure 21, indicate the source of water is from induced recharge from the Missouri River and land surface. As discussed previously, a zone of higher specific conductance along the south bank of the Missouri River coincides with parts of the CRAs of wells 1 and 3. The presence of this zone may indicate the south bank of the Missouri River near the Independence well field has consistently larger concentrations of wastewater indicator compounds that can be induced into the aquifer by pumping. The contributing recharge area for monitoring well 6 extends to the Missouri River to the east of the well field and groundwater flow paths parallel Mill Creek (fig. 21). Numerous potential source areas of groundwater contamination, including one active and two closed landfills, are in the Mill Creek Basin on the uplands south of the well field (fig. 23). The water quality in Mill Creek has the potential to affect water quality near the well field. The CRA for monitoring well nest 19 includes both the Missouri River and land surface near State Highway 291. The most likely source for wastewater indicator compounds for monitoring well nest 19 is the Missouri River.

Fuel compounds were analyzed in water samples from monitoring well nests $1,2,3,6,11,19,21,28$, and 29. Total BTEX was analyzed at least once in water samples from all monitoring well nests except 15 and 17. Spatial and temporal trends were not evident from the fuel compounds or total BTEX sample results. Fuel compounds were detected in samples from monitoring well nest 28, five times in 2002, 2006, and 2008 and total BTEX was detected in samples from monitoring well nest 21, three times in 2005, 2006, and 2007 (fig. 45 and table 20).

Alachlor and atrazine were detected in most samples from monitoring wells, and atrazine was detected more often than alachlor. The source of alachlor and atrazine in groundwater near the Independence well field is most likely from nearby agricultural land management practices or the Missouri River, or both. The CRAs for monitoring wells (fig. 21) indicate the CRAs for many of the wells with alachlor or atrazine detections greater than 10 percent intersect either agricultural land or the Missouri River streambed. The wells in nest 15 have CRAs almost entirely in the Missouri River and have the largest percentage of detections for both alachlor and atrazine.

\section{Summary}

The City of Independence, Missouri, operates a well field within the city limits of Sugar Creek, Missouri, in the Missouri River alluvial aquifer. The long-term presence of potential contaminant sources has created concerns about the increased potential for contamination and the cumulative effect of contamination on the quality of the source water to the Independence well field. Contributing recharge areas (CRA) were last determined for the Independence well field in 1996. Since that time, eight supply wells have been installed in the area north of the Missouri River and well pumpage has changed for the older supply wells. The change in pumping has likely altered groundwater flow and substantially changed the character of the CRA and groundwater travel times to the wells.

The U.S Geological Survey (USGS), in a cooperative study with the City of Independence, Missouri, simulated steady-state groundwater flow for 2007 well pumpage, average annual river stage, and average annual recharge to determine the hydraulic head distribution in the model area. Particletracking analysis was used to determine the CRA for supply wells and monitoring wells, the travel time from recharge areas to supply wells, recharge areas to monitoring wells, and from monitoring wells to supply wells.

The simulated CRA for the Independence well field is elongated upstream and extends to both sides of the Missouri River. The capture of groundwater by the supply wells as it moves downgradient toward the Missouri River causes the long up-valley extent of the CRA, especially north of the Missouri River.

Sixty-eight monitoring wells in 29 well nests are located within and near the Independence well field. Groundwater flow paths and recharge areas estimated for monitoring wells indicate the origin of water to each monitoring well, the travel time of that water from the recharge area, the flow path from the vicinity of each monitoring well to a supply well, and the travel time from the monitoring well to the supply well. Monitoring wells 14a and 14b have the shortest groundwater travel time from their CRA of 0.30 years and monitoring well 29a has the longest maximum groundwater travel time from its CRA of 1,701 years. Monitoring well 22a has the shortest groundwater travel time of 0.5 day to supply well 44 and monitoring well $3 \mathrm{~b}$ has the longest maximum travel time of 31.91 years to supply well 10 .

Potential point sources of contamination near the Independence well field include above- and below-ground storage tanks; hazardous waste generators including a closed oil refinery and industrial areas; mining activities; National Pollution Discharge Elimination System outfalls and stormwater discharge; Superfund sites; chemical spills adjacent to the well field along State Highway 291, along State Highway 210, and along the rail lines; chemical- or petroleum-product spills in the Missouri River; spills or runoff into Mill Creek from landfills; leaching of contaminants into groundwater from landfills in upland areas and then into the alluvial aquifer; and runoff from limestone mining operations south of the well field. Potential nonpoint source areas of contamination have larger areal extent and distribution and include infiltration of wastewater treatment land application of municipal sewage sludge on the north side of the Missouri River west of the well field and fertilizers and pesticides used on crops and on highway right-of-ways.

Water-quality samples were collected by USGS personnel during ongoing annual sampling of the Independence groundwater monitoring well network. Water-quality constituent groups include dissolved oxygen and physical properties, nutrients (inorganic nitrogen species and orthophosphate), 
major ions and trace elements, organic wastewater indicator compounds, fuel compounds, and total benzene, toluene, ethyl-benzene, and xylene (BTEX), alachlor, and atrazine.

Maximum concentrations for both total inorganic nitrogen and orthophosphate are largest in samples from monitoring wells screened in the shallower depth intervals and may indicate land-surface management practices are the sources of these constituents to groundwater. The Missouri SMCL for iron was exceeded in almost all samples from monitoring wells. The MCL for arsenic was exceeded 32 times in samples from monitoring wells. The MCL for barium was exceeded 5 times in samples from one well. The SMCL for manganese was exceeded 160 times in samples from all monitoring wells and IND. The most frequently detected wastewater indicator compounds were $N, N$-diethyl-meta-toluamide (DEET), phenol, caffeine, and metolachlor. The most frequently detected fuel compounds were toluene and benzene. Total BTEX was detected in 19 samples from 16 monitoring wells and IND. No temporal trend is evident for detections of fuel compounds from 1998 to 2008 or total BTEX from 1999 to 2008. Alachlor was detected in 22 samples from monitoring wells and in IND and concentrations were less than the MCL in all samples. Atrazine was detected in 37 samples from monitoring wells and IND. The MCL for atrazine was exceeded in one sample from well 16b.

Samples from monitoring wells with median concentrations of total inorganic nitrogen higher than $1 \mathrm{mg} / \mathrm{L}$ are located near agricultural land. The larger total inorganic nitrogen concentrations in these samples from monitoring wells may indicate that agricultural land practices are the source of nitrogen to groundwater. Largest median values of specific conductance; total inorganic nitrogen; dissolved calcium, magnesium, sodium, iron, arsenic, manganese, bicarbonate, and sulfate and detections of wastewater indicator compounds, generally were in water samples from well nests 1, 2, 3, and 4 . A zone of higher specific conductance along the south bank of the Missouri River coincides with parts of the CRAs of monitoring well nests 1, 2, 3, and 4. Zones of higher specific conductance were located just upstream from the Independence well field at south-bank outfalls from sewage treatment plants, the Blue River, and the south bank of the Missouri River near the closed oil refinery. The long-term presence of these south-bank outfalls and the large specific conductance indicate that the surface water at the south bank of the Missouri River near the Independence well field can be induced into the aquifer by pumping. Large median concentrations of sodium were found in water samples from well nests 5, 6, 8, 9, and 10 (31 to $40 \mathrm{mg} / \mathrm{L}$ ) and chloride from well nests 6 and 10 (31 to $50 \mathrm{mg} / \mathrm{L}$ ). The higher median concentrations of sodium and chloride in these samples from monitoring wells may be the result of road salt use on Missouri State Highway 291 or from Mill Creek which drains the uplands south of the Independence well field. Median concentrations of sodium and chloride north of the Missouri River are lower than south of the Missouri River. Lower chloride median concentrations in groundwater north of the river may indicate that this water entered the aquifer before industrial and commercial activities became widespread in this area. Large median concentrations of arsenic in samples from monitoring well nests 1, 2, 6, 22, 28 , and 29 are most likely associated with dissolution of iron and sulfide minerals and fluctuation between oxidizing and reducing conditions. Largest median concentrations for arsenic are in the shallow depth interval $(<12-\mathrm{m})$ where fluctuations between oxidizing and reducing conditions occur. Median concentrations of iron are large in all samples from monitoring wells and are most likely caused by the interaction between fluctuating oxidizing and reducing conditions and siderite and ferric hydroxide.

The largest number of detections of wastewater indicators were found in water samples from well nests $1,3,6$, and 19 . A zone of higher specific conductance along the south bank of the Missouri River coincides with parts of the contributing recharge areas of wells 1 and 3 . The presence of this zone may indicate the south bank of the Missouri River near the Independence well field may have consistently higher concentrations of wastewater indicator compounds that can be induced into the aquifer by pumping. Spatial and temporal trends are not evident from the fuel compounds or total BTEX sample results. Fuel compounds were detected in samples from monitoring well nest 28, five times in 2002, 2006, and 2008 and total BTEX was detected in samples from monitoring well nest 21, three times in 2005, 2006, and 2007.

Alachlor and atrazine were detected in most samples from monitoring wells and atrazine was detected more often than alachlor. The source of alachlor and atrazine in groundwater near the Independence well field is most likely from nearby agricultural land management practices and (or) the Missouri River. Contributing recharge areas for monitoring wells indicate the source areas for many of the wells with alachlor or atrazine detections greater than 10 percent have contributing recharge areas that intersect either agricultural land or the Missouri River bed. The wells in nest 15 have contributing recharge areas almost entirely in the Missouri River and have the largest percentage of detections for both alachlor and atrazine. 
Table 3. Water-level altitudes in monitoring wells near the Independence well field (1993-1999).

[Wells 1a through $29 \mathrm{~b}$ are shown on figures 2 and 4, wells 505A through 501W are shown on figure 5]

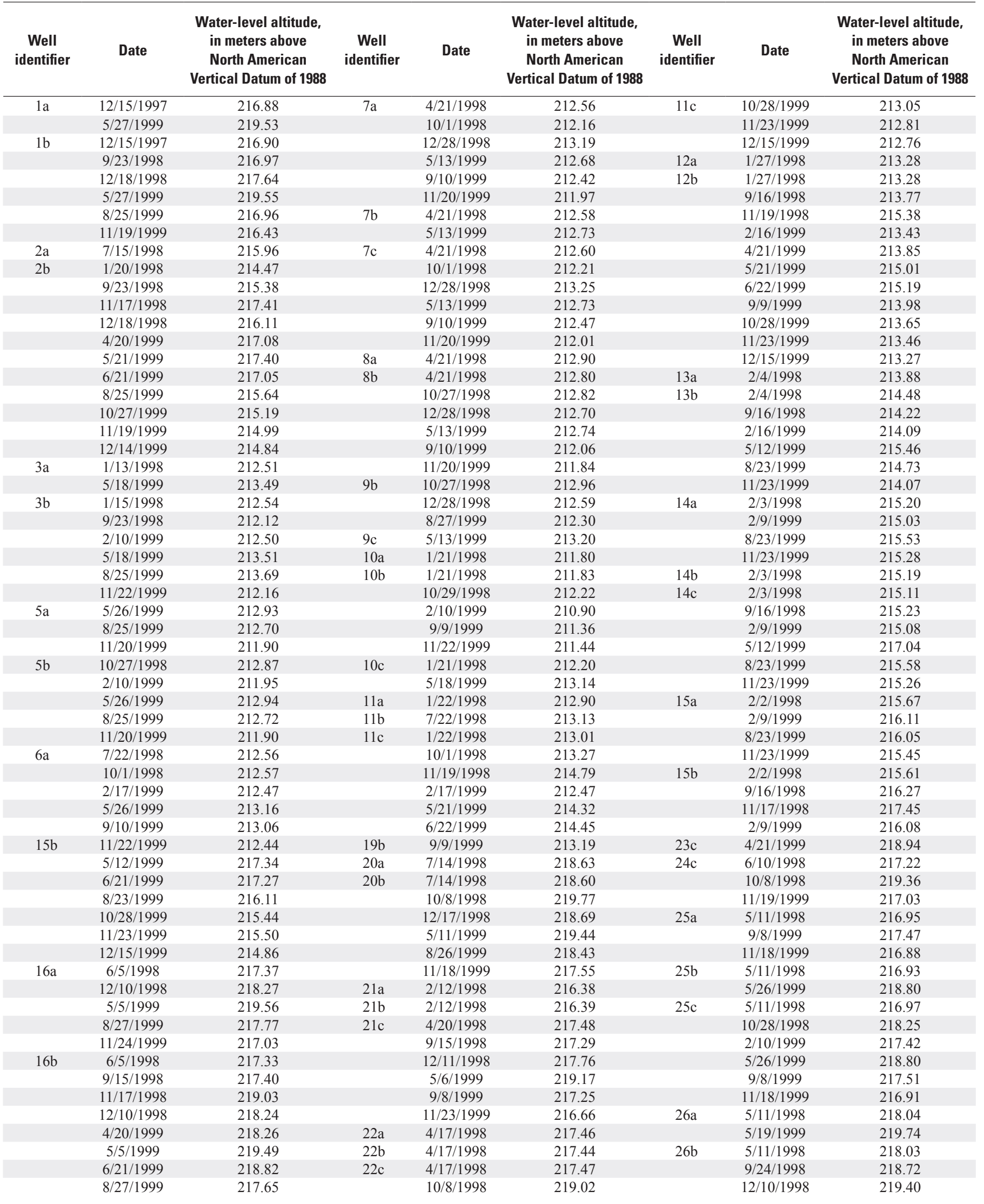


Table 3. Water-level altitudes in monitoring wells near the Independence well field (1993-1999)._Continued

[Wells 1a through 29b are shown on figures 2 and 4, wells 505A through 501W are shown on figure 5]

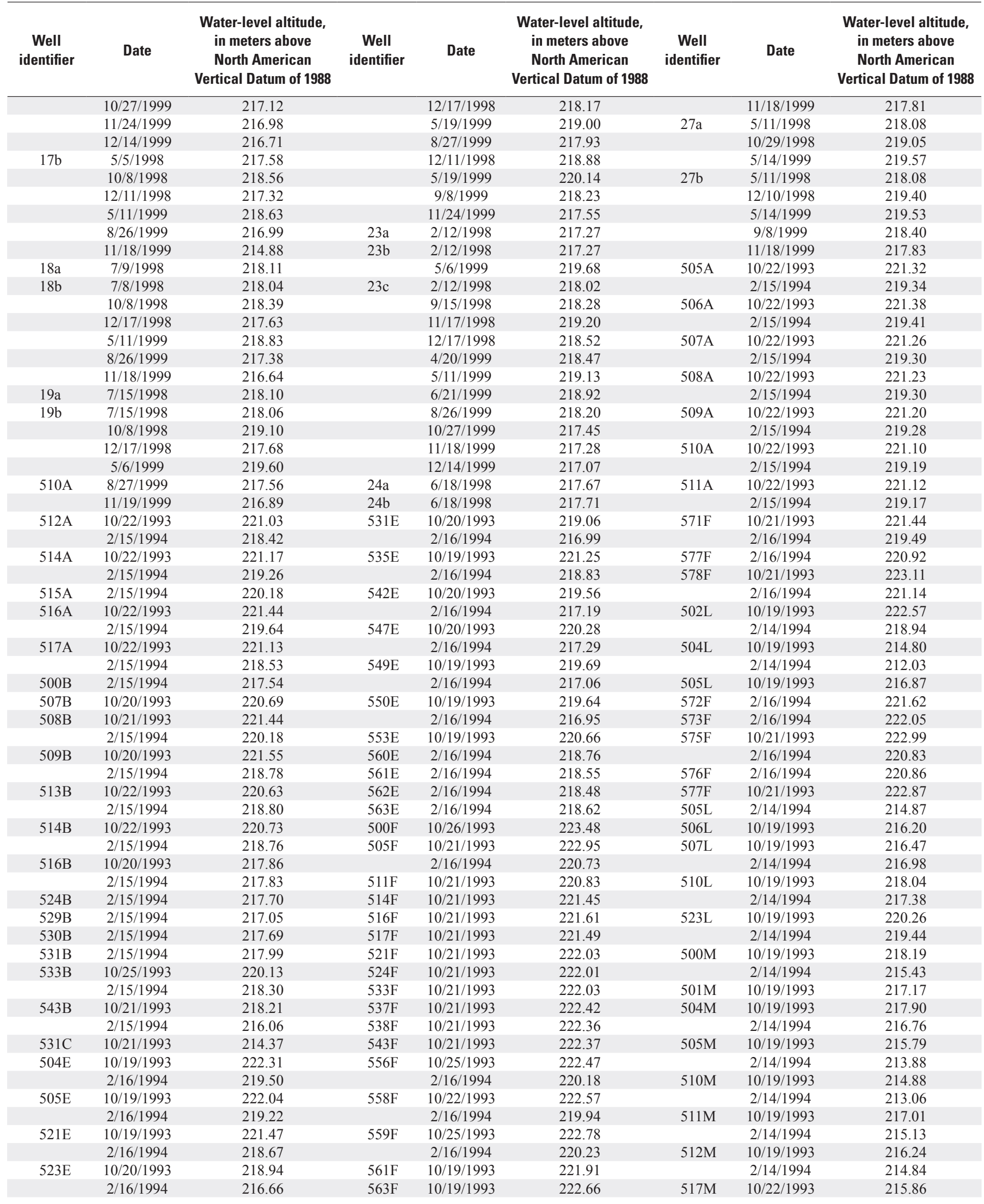


Table 3. Water-level altitudes in monitoring wells near the Independence well field (1993-1999).-Continued

[Wells 1a through 29b are shown on figures 2 and 4, wells 505A through 501W are shown on figure 5]

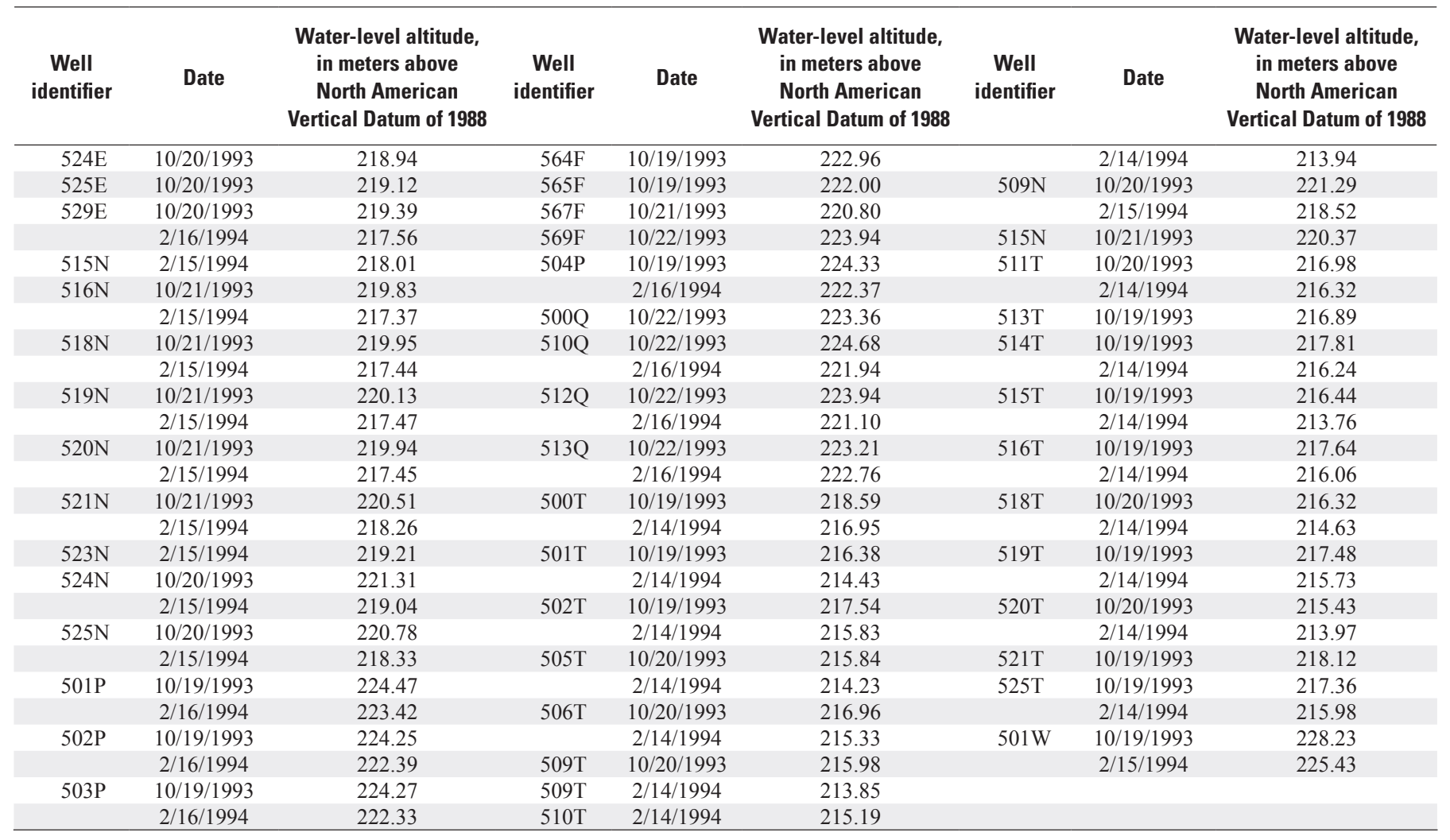


Table 5. Well pumpage used for the transient calibration simulation.

[L, layer number; $\mathrm{R}$, row number; $\mathrm{C}$, column number]

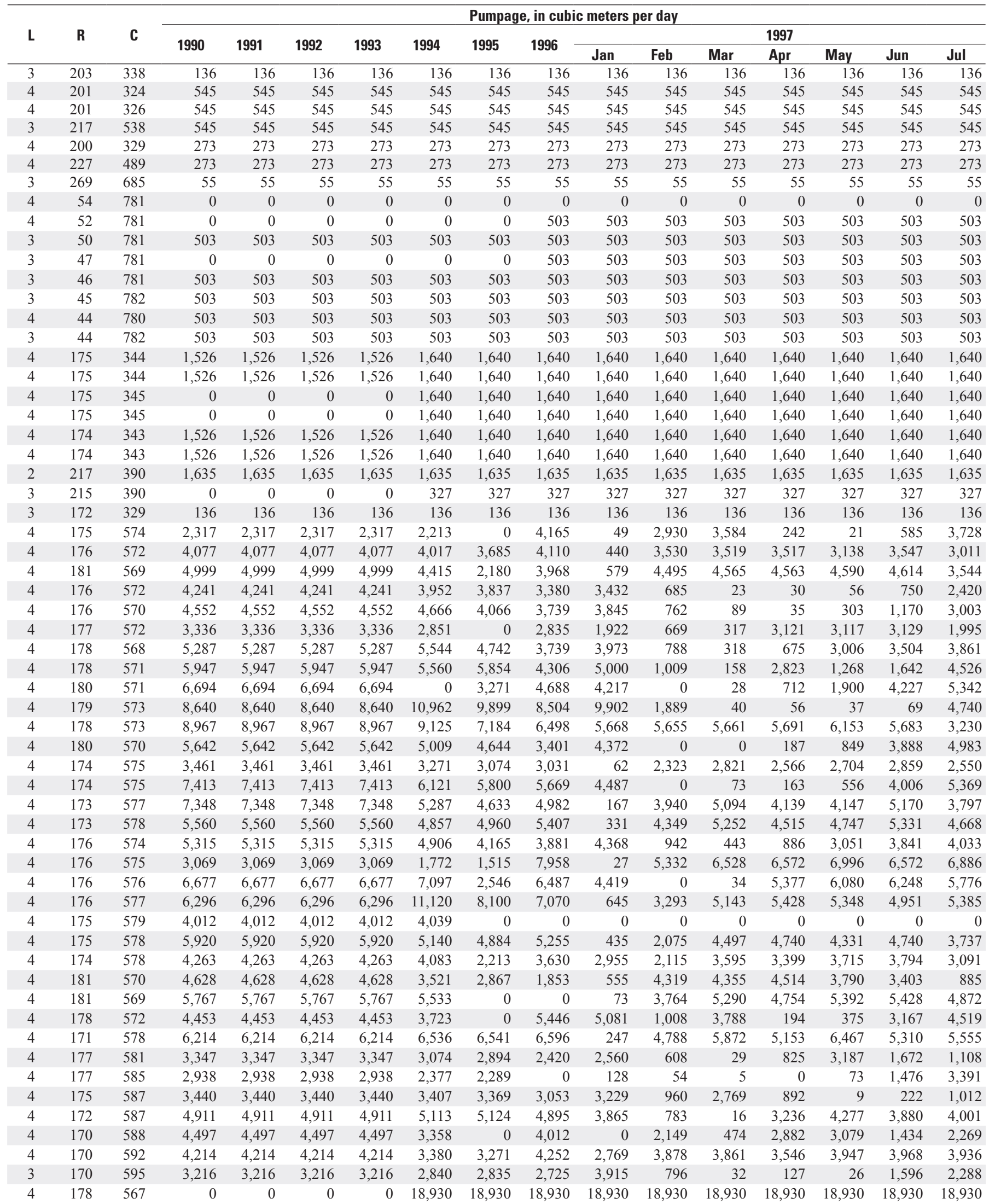


Table 5. Well pumpage used for the transient calibration simulation.-Continued

[L, layer number; $\mathrm{R}$, row number; $\mathrm{C}$, column number]

\begin{tabular}{|c|c|c|c|c|c|c|c|c|c|c|c|c|c|c|c|c|}
\hline \multirow{3}{*}{$\mathbf{L}$} & \multirow{3}{*}{$\mathbf{R}$} & \multirow{3}{*}{ C } & \multicolumn{14}{|c|}{ Pumpage, in cubic meters per day } \\
\hline & & & \multirow{2}{*}{1990} & \multirow{2}{*}{1991} & \multirow{2}{*}{1992} & \multirow{2}{*}{1993} & \multirow{2}{*}{1994} & \multirow{2}{*}{1995} & & & & & 1997 & & & \\
\hline & & & & & & & & & 1 & Jan & Feb & Mar & Apr & May & Jun & Jul \\
\hline 4 & 188 & 357 & 10,575 & 10,575 & 10,575 & 10,575 & 10,575 & 10,575 & 10,575 & 10,575 & 10,575 & 10,575 & 10,575 & 10,575 & 10,575 & 10,575 \\
\hline 4 & 187 & 357 & 10,575 & 10,575 & 10,575 & 10,575 & 10,575 & 10,575 & 10,575 & 10,575 & 10,575 & 10,575 & 10,575 & 10,575 & 10,575 & 10,575 \\
\hline 4 & 186 & 357 & 10,575 & 10,575 & 10,575 & 10,575 & 10,575 & 10,575 & 10,575 & 10,575 & 10,575 & 10,575 & 10,575 & 10,575 & 10,575 & 10,575 \\
\hline 4 & 185 & 357 & 10,575 & 10,575 & 10,575 & 10,575 & 10,575 & 10,575 & 10,575 & 10,575 & 10,575 & 10,575 & 10,575 & 10,575 & 10,575 & 10,575 \\
\hline 4 & 184 & 356 & 10,575 & 10,575 & 10,575 & 10,575 & 10,575 & 10,575 & 10,575 & 10,575 & 10,575 & 10,575 & 10,575 & 10,575 & 10,575 & 10,575 \\
\hline 4 & 184 & 356 & 10,575 & 10,575 & 10,575 & 10,575 & 10,575 & 10,575 & 10,575 & 10,575 & 10,575 & 10,575 & 10,575 & 10,575 & 10,575 & 10,575 \\
\hline 4 & 184 & 357 & 10,575 & 10,575 & 10,575 & 10,575 & 10,575 & 10,575 & 10,575 & 10,575 & 10,575 & 10,575 & 10,575 & 10,575 & 10,575 & 10,575 \\
\hline 4 & 183 & 355 & 0 & 0 & 0 & 0 & 0 & 0 & 10,575 & 10,575 & 10,575 & 10,575 & 10,575 & 10,575 & 10,575 & 10,575 \\
\hline 4 & 182 & 354 & 0 & 0 & 0 & 0 & 0 & 0 & 10,575 & 10,575 & 10,575 & 10,575 & 10,575 & 10,575 & 10,575 & 10,575 \\
\hline 4 & 182 & 359 & 10,575 & 10,575 & 10,575 & 10,575 & 10,575 & 10,575 & 10,575 & 10,575 & 10,575 & 10,575 & 10,575 & 10,575 & 10,575 & 10,575 \\
\hline 4 & 181 & 354 & 0 & 0 & 0 & 0 & 0 & 0 & 10,575 & 10,575 & 10,575 & 10,575 & 10,575 & 10,575 & 10,575 & 10,575 \\
\hline 4 & 180 & 352 & 10,575 & 10,575 & 10,575 & 10,575 & 10,575 & 10,575 & 10,575 & 10,575 & 10,575 & 10,575 & 10,575 & 10,575 & 10,575 & 10,575 \\
\hline 4 & 180 & 353 & 10,575 & 10,575 & 10,575 & 10,575 & 10,575 & 10,575 & 10,575 & 10,575 & 10,575 & 10,575 & 10,575 & 10,575 & 10,575 & 10,575 \\
\hline 4 & 180 & 359 & 10,575 & 10,575 & 10,575 & 10,575 & 10,575 & 10,575 & 10,575 & 10,575 & 10,575 & 10,575 & 10,575 & 10,575 & 10,575 & 10,575 \\
\hline 4 & 132 & 674 & 0 & 0 & 0 & 155 & 155 & 155 & 155 & 155 & 155 & 155 & 155 & 155 & 155 & 155 \\
\hline 4 & 131 & 674 & 0 & 0 & 0 & 155 & 155 & 155 & 155 & 155 & 155 & 155 & 155 & 155 & 155 & 155 \\
\hline 3 & 215 & 366 & 136 & 136 & 136 & 136 & 136 & 136 & 136 & 136 & 136 & 136 & 136 & 136 & 136 & 136 \\
\hline 4 & 201 & 552 & 409 & 409 & 409 & 409 & 409 & 409 & 409 & 409 & 409 & 409 & 409 & 409 & 409 & 409 \\
\hline 4 & 275 & 738 & 227 & 227 & 227 & 227 & 227 & 227 & 227 & 227 & 227 & 227 & 227 & 227 & 227 & 227 \\
\hline 4 & 274 & 712 & 227 & 227 & 227 & 227 & 227 & 227 & 227 & 227 & 227 & 227 & 227 & 227 & 227 & 227 \\
\hline 4 & 274 & 737 & 227 & 227 & 227 & 227 & 227 & 227 & 227 & 227 & 227 & 227 & 227 & 227 & 227 & 227 \\
\hline 4 & 271 & 726 & 227 & 227 & 227 & 227 & 227 & 227 & 227 & 227 & 227 & 227 & 227 & 227 & 227 & 227 \\
\hline 4 & 267 & 740 & 227 & 227 & 227 & 227 & 227 & 227 & 227 & 227 & 227 & 227 & 227 & 227 & 227 & 227 \\
\hline 3 & 266 & 712 & 227 & 227 & 227 & 227 & 227 & 227 & 227 & 227 & 227 & 227 & 227 & 227 & 227 & 227 \\
\hline 2 & 262 & 718 & 227 & 227 & 227 & 227 & 227 & 227 & 227 & 227 & 227 & 227 & 227 & 227 & 227 & 227 \\
\hline 4 & 259 & 736 & 227 & 227 & 227 & 227 & 227 & 227 & 227 & 227 & 227 & 227 & 227 & 227 & 227 & 227 \\
\hline 4 & 259 & 736 & 227 & 227 & 227 & 227 & 227 & 227 & 227 & 227 & 227 & 227 & 227 & 227 & 227 & 227 \\
\hline 4 & 9 & 53 & 1,010 & 1,010 & 1,010 & 1,010 & 1,010 & 1,010 & 1,010 & 1,010 & 1,010 & 1,010 & 1,010 & 1,010 & 1,010 & 1,010 \\
\hline 4 & 7 & 51 & 1,010 & 1,010 & 1,010 & 1,010 & 1,010 & 1,010 & 1,010 & 1,010 & 1,010 & 1,010 & 1,010 & 1,010 & 1,010 & 1,010 \\
\hline 4 & 6 & 49 & 1,010 & 1,010 & 1,010 & 1,010 & 1,010 & 1,010 & 1,010 & 1,010 & 1,010 & 1,010 & 1,010 & 1,010 & 1,010 & 1,010 \\
\hline 4 & 4 & 47 & 1,010 & 1,010 & 1,010 & 1,010 & 1,010 & 1,010 & 1,010 & 1,010 & 1,010 & 1,010 & 1,010 & 1,010 & 1,010 & 1,010 \\
\hline 4 & 2 & 44 & 1,010 & 1,010 & 1,010 & 1,010 & 1,010 & 1,010 & 1,010 & 1,010 & 1,010 & 1,010 & 1,010 & 1,010 & 1,010 & 1,010 \\
\hline 4 & 1 & 43 & 1,010 & 1,010 & 1,010 & 1,010 & 1,010 & 1,010 & 1,010 & 1,010 & 1,010 & 1,010 & 1,010 & 1,010 & 1,010 & 1,010 \\
\hline 4 & 129 & 592 & 833 & 833 & 833 & 833 & 833 & 833 & 833 & 833 & 833 & 833 & 833 & 833 & 833 & 833 \\
\hline 4 & 128 & 592 & 833 & 833 & 833 & 833 & 833 & 833 & 833 & 833 & 833 & 833 & 833 & 833 & 833 & 833 \\
\hline 4 & 127 & 592 & 833 & 833 & 833 & 833 & 833 & 833 & 833 & 833 & 833 & 833 & 833 & 833 & 833 & 833 \\
\hline 4 & 126 & 592 & 833 & 833 & 833 & 833 & 833 & 833 & 833 & 833 & 833 & 833 & 833 & 833 & 833 & 833 \\
\hline 4 & 125 & 592 & 833 & 833 & 833 & 833 & 833 & 833 & 833 & 833 & 833 & 833 & 833 & 833 & 833 & 833 \\
\hline 4 & 124 & 592 & 833 & 833 & 833 & 833 & 833 & 833 & 833 & 833 & 833 & 833 & 833 & 833 & 833 & 833 \\
\hline 4 & 123 & 592 & 833 & 833 & 833 & 833 & 833 & 833 & 833 & 833 & 833 & 833 & 833 & 833 & 833 & 833 \\
\hline 3 & 120 & 592 & 833 & 833 & 833 & 833 & 833 & 833 & 833 & 833 & 833 & 833 & 833 & 833 & 833 & 833 \\
\hline 3 & 119 & 592 & 833 & 833 & 833 & 833 & 833 & 833 & 833 & 833 & 833 & 833 & 833 & 833 & 833 & 833 \\
\hline 3 & 119 & 592 & 833 & 833 & 833 & 833 & 833 & 833 & 833 & 833 & 833 & 833 & 833 & 833 & 833 & 833 \\
\hline 4 & 139 & 239 & 2,110 & 2,110 & 2,110 & 2,110 & 2,110 & 2,110 & 2,110 & 2,110 & 2,110 & 2,110 & 2,110 & 2,110 & 2,110 & 2,110 \\
\hline 4 & 138 & 240 & 2,110 & 2,110 & 2,110 & 2,110 & 2,110 & 2,110 & 2,110 & 2,110 & 2,110 & 2,110 & 2,110 & 2,110 & 2,110 & 2,110 \\
\hline 4 & 138 & 241 & 2,110 & 2,110 & 2,110 & 2,110 & 2,110 & 2,110 & 2,110 & 2,110 & 2,110 & 2,110 & 2,110 & 2,110 & 2,110 & 2,110 \\
\hline 4 & 137 & 243 & 2,110 & 2,110 & 2,110 & 2,110 & 2,110 & 2,110 & 2,110 & 2,110 & 2,110 & 2,110 & 2,110 & 2,110 & 2,110 & 2,110 \\
\hline 4 & 231 & 367 & 1,090 & 1,110 & 1,200 & 1,290 & 1,380 & 1,470 & 1,560 & 1,650 & 1,650 & 1,650 & 1,650 & 1,650 & 1,650 & 1,650 \\
\hline 4 & 230 & 371 & 1,090 & 1,110 & 1,200 & 1,290 & 1,380 & 1,470 & 1,560 & 1,650 & 1,650 & 1,650 & 1,650 & 1,650 & 1,650 & 1,650 \\
\hline 4 & 230 & 376 & 1,090 & 1,110 & 1,200 & 1,290 & 1,380 & 1,470 & 1,560 & 1,650 & 1,650 & 1,650 & 1,650 & 1,650 & 1,650 & 1,650 \\
\hline 4 & 230 & 377 & 1,090 & 1,110 & 1,200 & 1,290 & 1,380 & 1,470 & 1,560 & 1,650 & 1,650 & 1,650 & 1,650 & 1,650 & 1,650 & 1,650 \\
\hline 4 & 228 & 375 & 1,090 & 1,110 & 1,200 & 1,290 & 1,380 & 1,470 & 1,560 & 1,650 & 1,650 & 1,650 & 1,650 & 1,650 & 1,650 & 1,650 \\
\hline 4 & 228 & 376 & 1,090 & 1,110 & 1,200 & 1,290 & 1,380 & 1,470 & 1,560 & 1,650 & 1,650 & 1,650 & 1,650 & 1,650 & 1,650 & 1,650 \\
\hline 4 & 226 & 375 & 1,090 & 1,110 & 1,200 & 1,290 & 1,380 & 1,470 & 1,560 & 1,650 & 1,650 & 1,650 & 1,650 & 1,650 & 1,650 & 1,650 \\
\hline 4 & 224 & 375 & 1,090 & 1,110 & 1,200 & 1,290 & 1,380 & 1,470 & 1,560 & 1,650 & 1,650 & 1,650 & 1,650 & 1,650 & 1,650 & 1,650 \\
\hline 4 & 208 & 364 & 1,650 & 1,650 & 1,650 & 1,650 & 1,650 & 1,650 & 1,650 & 1,650 & 1,650 & 1,650 & 1,650 & 1,650 & 1,650 & 1,650 \\
\hline 4 & 206 & 364 & 2,200 & 2,200 & 2,200 & 2,200 & 2,200 & 0 & 0 & 0 & 0 & 0 & 0 & 0 & 0 & 0 \\
\hline 4 & 205 & 363 & 0 & 0 & 0 & 0 & 0 & 0 & 0 & 0 & 0 & 0 & 0 & 0 & 0 & 0 \\
\hline 4 & 205 & 364 & 0 & 0 & 0 & 0 & 0 & 0 & 0 & 0 & 0 & 0 & 0 & 0 & 0 & 0 \\
\hline
\end{tabular}


Table 5. Well pumpage used for the transient calibration simulation.-Continued

[L, layer number; $\mathrm{R}$, row number; $\mathrm{C}$, column number]

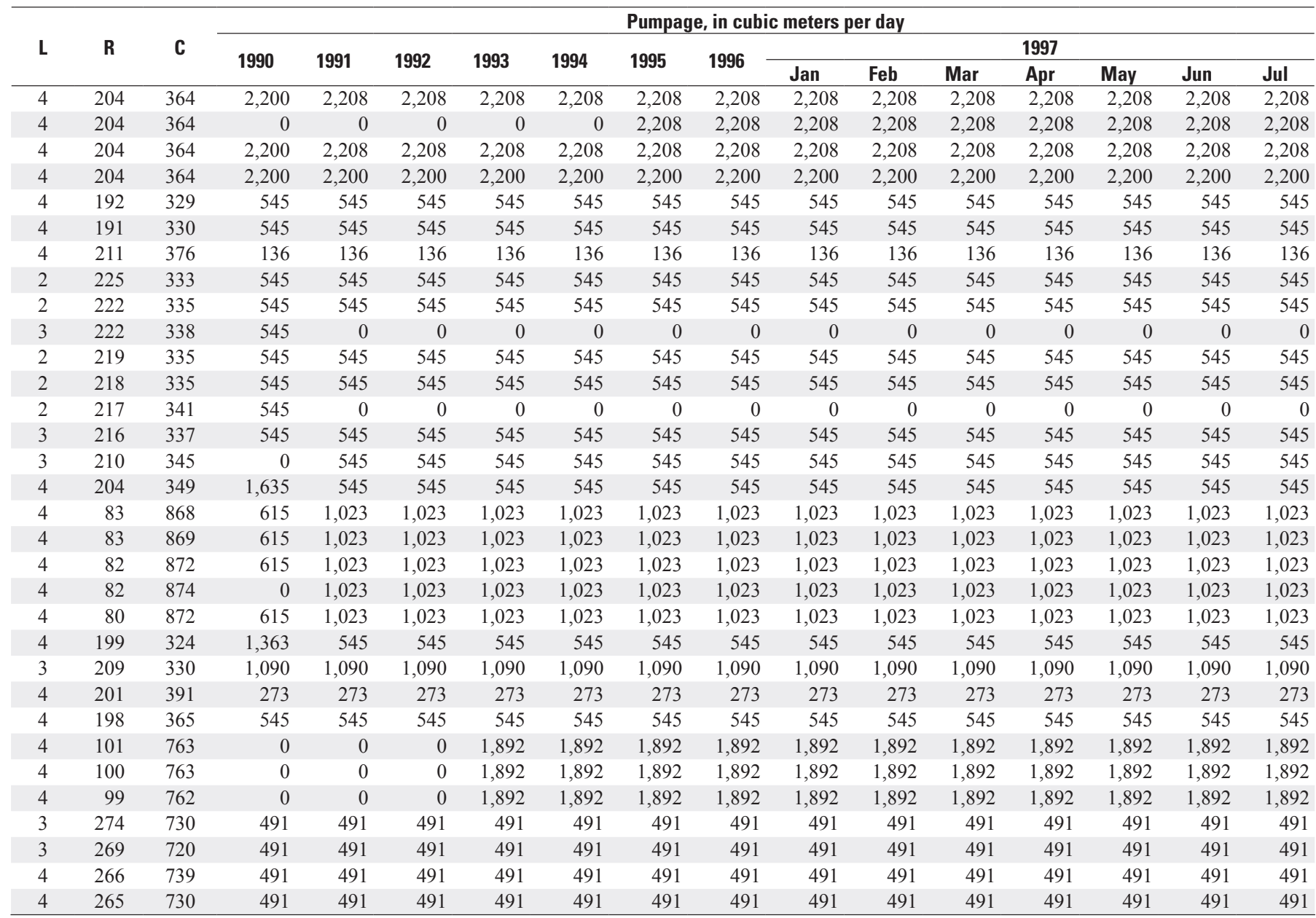

\begin{tabular}{|c|c|c|c|c|c|c|c|c|c|c|c|c|c|c|c|c|}
\hline \multirow[b]{2}{*}{$\mathbf{L}$} & \multirow[b]{2}{*}{$\mathbf{R}$} & \multirow[b]{2}{*}{ C } & \multicolumn{14}{|c|}{ Pumpage, in cubic meters per day } \\
\hline & & & \multicolumn{5}{|c|}{1997} & \multicolumn{9}{|c|}{1998} \\
\hline 3 & 203 & 338 & 136 & 136 & 136 & 136 & 136 & 136 & 136 & 136 & 136 & 136 & 136 & 136 & 136 & 136 \\
\hline 4 & 201 & 326 & 545 & 545 & 545 & 545 & 545 & 545 & 545 & 545 & 545 & 545 & 545 & 545 & 545 & 545 \\
\hline 3 & 217 & 538 & 545 & 545 & 545 & 545 & 545 & 545 & 545 & 545 & 545 & 545 & 545 & 545 & 545 & 545 \\
\hline 4 & 200 & 329 & 273 & 273 & 273 & 273 & 273 & 273 & 273 & 273 & 273 & 273 & 273 & 273 & 273 & 273 \\
\hline 4 & 227 & 489 & 273 & 273 & 273 & 273 & 273 & 273 & 273 & 273 & 273 & 273 & 273 & 273 & 273 & 273 \\
\hline 4 & 52 & 781 & 503 & 503 & 503 & 503 & 503 & 503 & 503 & 503 & 503 & 503 & 503 & 503 & 503 & 503 \\
\hline 3 & 50 & 781 & 503 & 503 & 503 & 503 & 503 & 503 & 503 & 503 & 503 & 503 & 503 & 503 & 503 & 503 \\
\hline 3 & 47 & 781 & 503 & 503 & 503 & 503 & 503 & 503 & 503 & 503 & 503 & 503 & 503 & 503 & 503 & 503 \\
\hline 3 & 46 & 781 & 503 & 503 & 503 & 503 & 503 & 503 & 503 & 503 & 503 & 503 & 503 & 503 & 503 & 503 \\
\hline 3 & 45 & 782 & 503 & 503 & 503 & 503 & 503 & 503 & 503 & 503 & 503 & 503 & 503 & 503 & 503 & 503 \\
\hline 4 & 44 & 780 & 503 & 503 & 503 & 503 & 503 & 503 & 503 & 503 & 503 & 503 & 503 & 503 & 503 & 503 \\
\hline 4 & 175 & 345 & 1,640 & 1,640 & 1,640 & 1,640 & 1,640 & 1,640 & 1,640 & 1,640 & 1,640 & 1,640 & 1,640 & 1,640 & 1,640 & 1,640 \\
\hline 4 & 174 & 343 & 1,640 & 1,640 & 1,640 & 1,640 & 1,640 & 1,640 & 1,640 & 1,640 & 1,640 & 1,640 & 1,640 & 1,640 & 1,640 & 1,640 \\
\hline
\end{tabular}


Table 5. Well pumpage used for the transient calibration simulation.-Continued

[L, layer number; $\mathrm{R}$, row number; $\mathrm{C}$, column number]

\begin{tabular}{|c|c|c|c|c|c|c|c|c|c|c|c|c|c|c|c|c|}
\hline \multirow{3}{*}{$\mathbf{L}$} & \multirow{3}{*}{$\mathbf{R}$} & \multirow{3}{*}{ C } & \multicolumn{14}{|c|}{ Pumpage, in cubic meters per day } \\
\hline & & & \multicolumn{5}{|c|}{1997} & \multicolumn{9}{|c|}{1998} \\
\hline & & & Aug & Sep & Oct & Nov & Dec & Jan & Feb & Mar & Apr & May & Jun & Jul & Aug & Sep \\
\hline 4 & 174 & 343 & 1,640 & 1,640 & 1,640 & 1,640 & 1,640 & 1,640 & 1,640 & 1,640 & 1,640 & 1,640 & 1,640 & 1,640 & 1,640 & 1,640 \\
\hline 2 & 217 & 390 & 1,635 & 1,635 & 1,635 & 1,635 & 1,635 & 1,635 & 1,635 & 1,635 & 1,635 & 1,635 & 1,635 & 1,635 & 1,635 & 1,635 \\
\hline 3 & 215 & 390 & 327 & 327 & 327 & 327 & 327 & 327 & 327 & 327 & 327 & 327 & 327 & 327 & 327 & 327 \\
\hline 3 & 172 & 329 & 136 & 136 & 136 & 136 & 136 & 136 & 136 & 136 & 136 & 136 & 136 & 136 & 136 & 136 \\
\hline 4 & 175 & 574 & 3,623 & 4,173 & 2,940 & 3,404 & 3,357 & 3,177 & 3,196 & 3,736 & 3,655 & 2,539 & 360 & 3,667 & 3,065 & 3,034 \\
\hline 4 & 176 & 572 & 1,516 & 850 & 1,188 & 2,911 & 3,028 & 2,449 & 2,242 & 1,934 & 2,348 & 2,924 & 2,430 & 0 & 331 & 2,768 \\
\hline 4 & 181 & 569 & 3,201 & 968 & 3,974 & 3,734 & 4,833 & 3,785 & 585 & 1,219 & 521 & 3,839 & 4,173 & 2,789 & 2,169 & 3,995 \\
\hline 4 & 176 & 572 & 3,488 & 3,421 & 3,436 & 3,740 & 3,245 & 2,313 & 85 & 553 & 96 & 226 & 3,498 & 206 & 1,333 & 1,404 \\
\hline 4 & 176 & 570 & 4,066 & 4,022 & 3,958 & 3,677 & 3,791 & 3,466 & 3,736 & 3,334 & 3,440 & 2,396 & 632 & 3,996 & 3,883 & 3,836 \\
\hline 4 & 177 & 572 & 1,237 & 46 & 900 & 2,885 & 2,394 & 14,333 & 451 & 468 & 160 & 1,156 & 3,297 & 1,604 & 2,010 & 3,546 \\
\hline 4 & 178 & 568 & 3,942 & 3,789 & 3,936 & 3,827 & 4,259 & 4,731 & 4,056 & 3,442 & 2,580 & 1,914 & 717 & 2,185 & 2,610 & 2,803 \\
\hline 4 & 178 & 571 & 4,142 & 4,048 & 5,634 & 4,577 & 5,535 & 4,671 & 5,132 & 4,968 & 4,797 & 4,718 & 1,551 & 4,637 & 4,530 & 4,460 \\
\hline 4 & 180 & 571 & 4,895 & 4,562 & 4,923 & 1,680 & 111 & 22 & 33 & 4,825 & 5,081 & 5,211 & 4,511 & 4,631 & 4,577 & 2,778 \\
\hline 4 & 179 & 573 & 9,433 & 10,298 & 10,900 & 9,195 & 10,308 & 9,651 & 9,764 & 1,121 & 28 & 4,282 & 9,916 & 3,520 & 206 & 6,796 \\
\hline 4 & 178 & 573 & 54 & 32 & 0 & 0 & 0 & 14 & 11,417 & 11,201 & 9,986 & 1,534 & 0 & 3,539 & 8,885 & 2,902 \\
\hline 4 & 180 & 570 & 5,445 & 4,649 & 4,656 & 1,971 & 28 & 41 & 23 & 14 & 23 & 1,800 & 5,526 & 4,914 & 4,212 & 3,452 \\
\hline 4 & 174 & 575 & 1,063 & 52 & 879 & 1,998 & 1,125 & 37 & 15 & 69 & 21 & 4 & 77 & 1,526 & 2,646 & 1,803 \\
\hline 4 & 174 & 575 & 5,694 & 5,830 & 5,100 & 4,266 & 5,403 & 4,907 & 4,909 & 4,745 & 4,877 & 3,600 & 553 & 3,411 & 4,948 & 3,005 \\
\hline 4 & 173 & 577 & 1,798 & 89 & 800 & 3,895 & 5,561 & 2,301 & 0 & 0 & 0 & 1,501 & 5,098 & 4,293 & 2,757 & 4,624 \\
\hline 4 & 173 & 578 & 2,302 & 104 & 32 & 3,667 & 4,465 & 123 & 1,639 & 161 & 20 & 2,443 & 5,568 & 1,213 & 1,086 & 5,196 \\
\hline 4 & 176 & 574 & 3,676 & 4,541 & 4,206 & 1,301 & 54 & 41 & 20 & 18 & 30 & 1,625 & 4,107 & 3,882 & 3,926 & 1,842 \\
\hline 4 & 176 & 575 & 4,280 & 4,033 & 266 & 284 & 27 & 29 & 32 & 77 & 28 & 3,553 & 6,832 & 5,426 & 4,282 & 6,623 \\
\hline 4 & 176 & 576 & 3,531 & 284 & 269 & 4,219 & 2,085 & 6,118 & 6,042 & 5,862 & 5,903 & 4,895 & 545 & 933 & 968 & 4,545 \\
\hline 4 & 176 & 577 & 5,422 & 5,406 & 5,414 & 5,246 & 5,334 & 4,847 & 2,219 & 73 & 644 & 4,267 & 4,836 & 2,104 & 1,794 & 4,571 \\
\hline 4 & 175 & 579 & 0 & 0 & 0 & 0 & 0 & 0 & 0 & 0 & 0 & 0 & 0 & 0 & 0 & 0 \\
\hline 4 & 175 & 578 & 2,601 & 213 & 297 & 0 & 58 & 38 & 21 & 50 & 34 & 2,202 & 4,607 & 3,554 & 3,177 & 1,753 \\
\hline 4 & 174 & 578 & 2,529 & 2,908 & 908 & 50 & 31 & 15 & 2,019 & 2,851 & 3,062 & 2,854 & 3,412 & 2,585 & 2,369 & 1,116 \\
\hline 4 & 181 & 570 & 1,941 & 1,570 & 3,241 & 1,319 & 43 & 24 & 26 & 140 & 32 & 1,581 & 4,231 & 4,183 & 3,718 & 2,581 \\
\hline 4 & 181 & 569 & 3,319 & 4,573 & 4,411 & 4,945 & 315 & 1,628 & 5,402 & 4,880 & 4,312 & 2,286 & 223 & 3,727 & 3,931 & 1,087 \\
\hline 4 & 178 & 572 & 5,102 & 4,489 & 5,165 & 4,838 & 336 & 1,682 & 2,219 & 334 & 947 & 3,871 & 3,797 & 4,208 & 4,050 & 920 \\
\hline 4 & 171 & 578 & 5,056 & 5,535 & 4,825 & 1,851 & 64 & 48 & 4,929 & 5,707 & 4,679 & 5,820 & 4,932 & 0 & 917 & 6,187 \\
\hline 4 & 177 & 581 & 2,906 & 2,826 & 2,150 & 598 & 29 & 8 & 22 & 0 & 12 & 1,339 & 2,649 & 3,428 & 1,939 & 17 \\
\hline 4 & 177 & 585 & 3,245 & 3,556 & 1,104 & 589 & 1,561 & 3,644 & 3,344 & 3,183 & 3,363 & 1,594 & 289 & 2,580 & 3,406 & 675 \\
\hline 4 & 175 & 587 & 315 & 23 & 0 & 92 & 889 & 4,012 & 3,630 & 3,438 & 3,518 & 3,288 & 3,234 & 2,437 & 2,905 & 3,334 \\
\hline 4 & 172 & 587 & 2,475 & 3,185 & 937 & 2,006 & 262 & 42 & 2,517 & 4,219 & 2,905 & 2,794 & 1,289 & 3,065 & 3,947 & 751 \\
\hline 4 & 170 & 588 & 415 & 1,823 & 2,306 & 764 & 3,022 & 3,144 & 3,132 & 3,050 & 3,725 & 3,508 & 2,264 & 3,135 & 2,798 & 2,529 \\
\hline 4 & 170 & 592 & 2,707 & 2,197 & 584 & 220 & 37 & 36 & 2,055 & 3,773 & 3,795 & 3,685 & 3,263 & 2,939 & 3,785 & 2,136 \\
\hline 3 & 170 & 595 & 3,157 & 2,954 & 2,821 & 778 & 134 & 16 & 24 & 5 & 17 & 1,572 & 3,455 & 1,772 & 1,904 & 3,243 \\
\hline 4 & 178 & 567 & 18,930 & 18,930 & 18,930 & 18,930 & 18,930 & 18,930 & 18,930 & 18,930 & 18,930 & 18,930 & 18,930 & 18,930 & 18,930 & 18,930 \\
\hline 4 & 188 & 357 & 10,575 & 10,575 & 10,575 & 10,575 & 10,575 & 10,575 & 10,575 & 10,575 & 10,575 & 10,575 & 10,575 & 10,575 & 10,575 & 10,575 \\
\hline 4 & 187 & 357 & 10,575 & 10,575 & 10,575 & 10,575 & 10,575 & 10,575 & 10,575 & 10,575 & 10,575 & 10,575 & 10,575 & 10,575 & 10,575 & 10,575 \\
\hline 4 & 186 & 357 & 10,575 & 10,575 & 10,575 & 10,575 & 10,575 & 10,575 & 10,575 & 10,575 & 10,575 & 10,575 & 10,575 & 10,575 & 10,575 & 10,575 \\
\hline 4 & 185 & 357 & 10,575 & 10,575 & 10,575 & 10,575 & 10,575 & 10,575 & 10,575 & 10,575 & 10,575 & 10,575 & 10,575 & 10,575 & 10,575 & 10,575 \\
\hline 4 & 184 & 356 & 10,575 & 10,575 & 10,575 & 10,575 & 10,575 & 10,575 & 10,575 & 10,575 & 10,575 & 10,575 & 10,575 & 10,575 & 10,575 & 10,575 \\
\hline 4 & 184 & 356 & 10,575 & 10,575 & 10,575 & 10,575 & 10,575 & 10,575 & 10,575 & 10,575 & 10,575 & 10,575 & 10,575 & 10,575 & 10,575 & 10,575 \\
\hline 4 & 184 & 357 & 10,575 & 10,575 & 10,575 & 10,575 & 10,575 & 10,575 & 10,575 & 10,575 & 10,575 & 10,575 & 10,575 & 10,575 & 10,575 & 10,575 \\
\hline 4 & 183 & 355 & 10,575 & 10,575 & 10,575 & 10,575 & 10,575 & 10,575 & 10,575 & 10,575 & 10,575 & 10,575 & 10,575 & 10,575 & 10,575 & 10,575 \\
\hline 4 & 182 & 354 & 10,575 & 10,575 & 10,575 & 10,575 & 10,575 & 10,575 & 10,575 & 10,575 & 10,575 & 10,575 & 10,575 & 10,575 & 10,575 & 10,575 \\
\hline 4 & 182 & 359 & 10,575 & 10,575 & 10,575 & 10,575 & 10,575 & 10,575 & 10,575 & 10,575 & 10,575 & 10,575 & 10,575 & 10,575 & 10,575 & 10,575 \\
\hline 4 & 181 & 354 & 10,575 & 10,575 & 10,575 & 10,575 & 10,575 & 10,575 & 10,575 & 10,575 & 10,575 & 10,575 & 10,575 & 10,575 & 10,575 & 10,575 \\
\hline 4 & 180 & 352 & 10,575 & 10,575 & 10,575 & 10,575 & 10,575 & 10,575 & 10,575 & 10,575 & 10,575 & 10,575 & 10,575 & 10,575 & 10,575 & 10,575 \\
\hline 4 & 180 & 353 & 10,575 & 10,575 & 10,575 & 10,575 & 10,575 & 10,575 & 10,575 & 10,575 & 10,575 & 10,575 & 10,575 & 10,575 & 10,575 & 10,575 \\
\hline 4 & 180 & 359 & 10,575 & 10,575 & 10,575 & 10,575 & 10,575 & 10,575 & 10,575 & 10,575 & 10,575 & 10,575 & 10,575 & 10,575 & 10,575 & 10,575 \\
\hline 4 & 132 & 674 & 155 & 155 & 155 & 155 & 155 & 155 & 155 & 155 & 155 & 155 & 155 & 155 & 155 & 155 \\
\hline 4 & 131 & 674 & 155 & 155 & 155 & 155 & 155 & 155 & 155 & 155 & 155 & 155 & 155 & 155 & 155 & 155 \\
\hline 3 & 215 & 366 & 136 & 136 & 136 & 136 & 136 & 136 & 136 & 136 & 136 & 136 & 136 & 136 & 136 & 136 \\
\hline 4 & 201 & 552 & 409 & 409 & 409 & 409 & 409 & 409 & 409 & 409 & 409 & 409 & 409 & 409 & 409 & 409 \\
\hline 4 & 275 & 738 & 227 & 227 & 227 & 227 & 227 & 227 & 227 & 227 & 227 & 227 & 227 & 227 & 227 & 227 \\
\hline 4 & 274 & 712 & 227 & 227 & 227 & 227 & 227 & 227 & 227 & 227 & 227 & 227 & 227 & 227 & 227 & 227 \\
\hline
\end{tabular}


Table 5. Well pumpage used for the transient calibration simulation. - Continued

[L, layer number; R, row number; $\mathrm{C}$, column number]

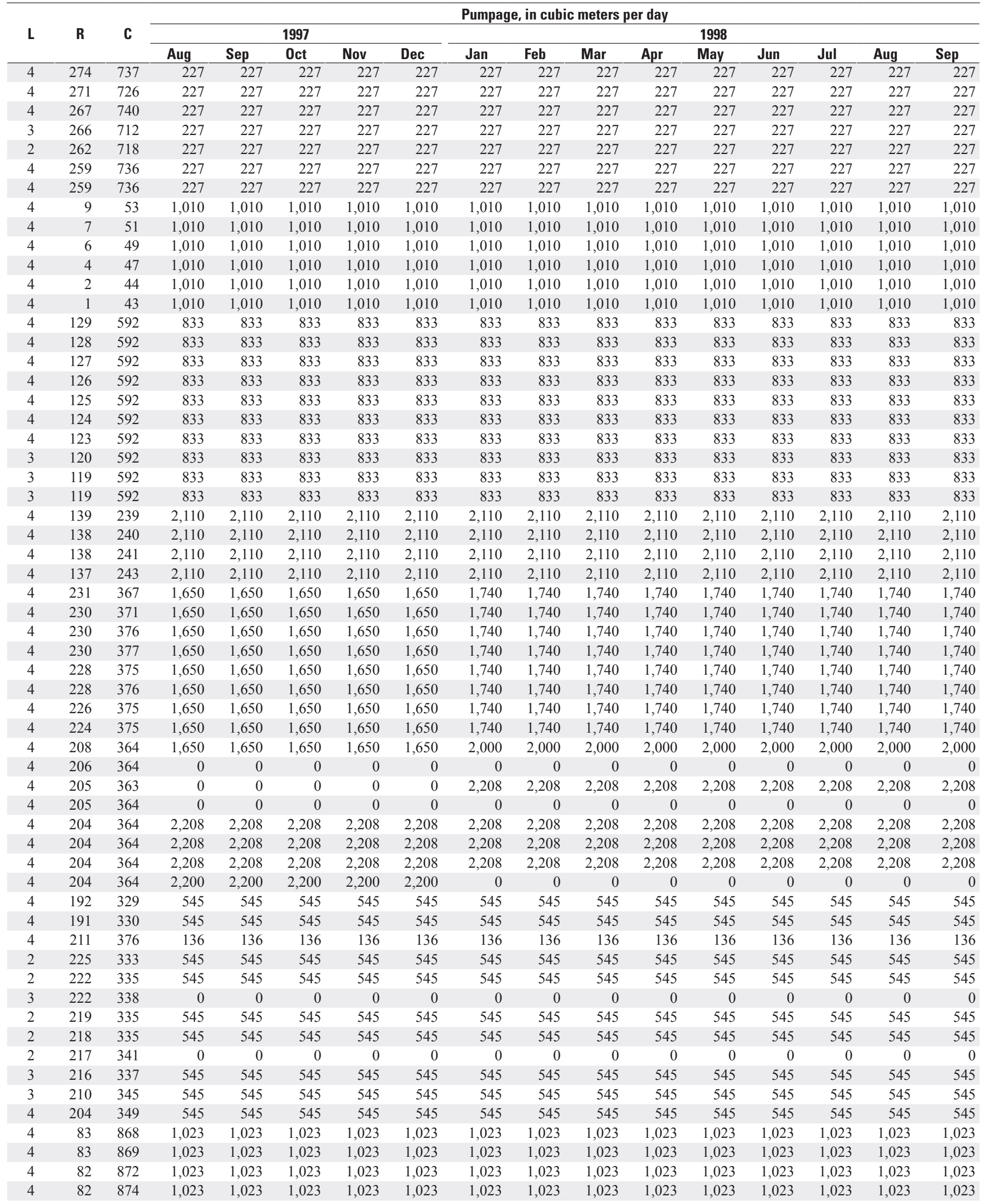


Table 5. Well pumpage used for the transient calibration simulation.-Continued

[L, layer number; $\mathrm{R}$, row number; $\mathrm{C}$, column number]

\begin{tabular}{|c|c|c|c|c|c|c|c|c|c|c|c|c|c|c|c|c|}
\hline \multirow{3}{*}{$\mathbf{L}$} & \multirow{3}{*}{$\mathbf{R}$} & \multirow{3}{*}{ C } & \multicolumn{14}{|c|}{ Pumpage, in cubic meters per day } \\
\hline & & & \multicolumn{5}{|c|}{1997} & \multicolumn{9}{|c|}{1998} \\
\hline & & & Aug & Sep & Oct & Nov & Dec & Jan & Feb & Mar & Apr & May & Jun & Jul & Aug & Sep \\
\hline 4 & 80 & 872 & 1,023 & 1,023 & 1,023 & 1,023 & 1,023 & 1,023 & 1,023 & 1,023 & 1,023 & 1,023 & 1,023 & 1,023 & 1,023 & 1,023 \\
\hline 4 & 199 & 324 & 545 & 545 & 545 & 545 & 545 & 545 & 545 & 545 & 545 & 545 & 545 & 545 & 545 & 545 \\
\hline 3 & 209 & 330 & 1,090 & 1,090 & 1,090 & 1,090 & 1,090 & 1,090 & 1,090 & 1,090 & 1,090 & 1,090 & 1,090 & 1,090 & 1,090 & 1,090 \\
\hline 4 & 201 & 391 & 273 & 273 & 273 & 273 & 273 & 273 & 273 & 273 & 273 & 273 & 273 & 273 & 273 & 273 \\
\hline 4 & 198 & 365 & 545 & 545 & 545 & 545 & 545 & 545 & 545 & 545 & 545 & 545 & 545 & 545 & 545 & 545 \\
\hline 4 & 101 & 763 & 1,892 & 1,892 & 1,892 & 1,892 & 1,892 & 1,892 & 1,892 & 1,892 & 1,892 & 1,892 & 1,892 & 1,892 & 1,892 & 1,892 \\
\hline 4 & 100 & 763 & 1,892 & 1,892 & 1,892 & 1,892 & 1,892 & 1,892 & 1,892 & 1,892 & 1,892 & 1,892 & 1,892 & 1,892 & 1,892 & 1,892 \\
\hline 4 & 99 & 762 & 1,892 & 1,892 & 1,892 & 1,892 & 1,892 & 1,892 & 1,892 & 1,892 & 1,892 & 1,892 & 1,892 & 1,892 & 1,892 & 1,892 \\
\hline 3 & 274 & 730 & 491 & 491 & 491 & 491 & 491 & 491 & 491 & 491 & 491 & 491 & 491 & 491 & 491 & 491 \\
\hline 3 & 269 & 720 & 491 & 491 & 491 & 491 & 491 & 491 & 491 & 491 & 491 & 491 & 491 & 491 & 491 & 491 \\
\hline 4 & 266 & 739 & 491 & 491 & 491 & 491 & 491 & 491 & 491 & 491 & 491 & 491 & 491 & 491 & 491 & 491 \\
\hline 4 & 265 & 730 & 491 & 491 & 491 & 491 & 491 & 491 & 491 & 491 & 491 & 491 & 491 & 491 & 491 & 491 \\
\hline
\end{tabular}

\begin{tabular}{|c|c|c|c|c|c|c|c|c|c|c|c|c|c|c|c|c|}
\hline \multirow[b]{2}{*}{$\mathbf{L}$} & \multirow[b]{2}{*}{$\mathbf{R}$} & \multirow[b]{2}{*}{ C } & \multicolumn{14}{|c|}{ Pumpage, in cubic meters per day } \\
\hline & & & \multicolumn{3}{|c|}{1998} & \multicolumn{11}{|c|}{1999} \\
\hline 3 & 203 & 338 & 136 & 136 & 136 & 136 & 136 & 136 & 136 & 136 & 136 & 136 & 136 & 136 & 136 & 136 \\
\hline 4 & 201 & 326 & 545 & 545 & 545 & 545 & 545 & 545 & 545 & 545 & 545 & 545 & 545 & 545 & 545 & 545 \\
\hline 3 & 217 & 538 & 545 & 545 & 545 & 545 & 545 & 545 & 545 & 545 & 545 & 545 & 545 & 545 & 545 & 545 \\
\hline 4 & 200 & 329 & 273 & 273 & 273 & 273 & 273 & 273 & 273 & 273 & 273 & 273 & 273 & 273 & 273 & 273 \\
\hline 4 & 54 & 781 & 0 & 0 & 0 & 629 & 629 & 629 & 629 & 629 & 629 & 629 & 629 & 629 & 629 & 629 \\
\hline 4 & 52 & 781 & 503 & 503 & 503 & 629 & 629 & 629 & 629 & 629 & 629 & 629 & 629 & 629 & 629 & 629 \\
\hline 3 & 50 & 781 & 503 & 503 & 503 & 629 & 629 & 629 & 629 & 629 & 629 & 629 & 629 & 629 & 629 & 629 \\
\hline 3 & 47 & 781 & 503 & 503 & 503 & 629 & 629 & 629 & 629 & 629 & 629 & 629 & 629 & 629 & 629 & 629 \\
\hline 3 & 46 & 781 & 503 & 503 & 503 & 629 & 629 & 629 & 629 & 629 & 629 & 629 & 629 & 629 & 629 & 629 \\
\hline 3 & 45 & 782 & 503 & 503 & 503 & 629 & 629 & 629 & 629 & 629 & 629 & 629 & 629 & 629 & 629 & 629 \\
\hline 4 & 175 & 345 & 1,640 & 1,640 & 1,640 & 1,640 & 1,640 & 1,640 & 1,640 & 1,640 & 1,640 & 1,640 & 1,640 & 1,640 & 1,640 & 1,640 \\
\hline 4 & 175 & 345 & 1,640 & 1,640 & 1,640 & 1,640 & 1,640 & 1,640 & 1,640 & 1,640 & 1,640 & 1,640 & 1,640 & 1,640 & 1,640 & 1,640 \\
\hline 4 & 174 & 343 & 1,640 & 1,640 & 1,640 & 1,640 & 1,640 & 1,640 & 1,640 & 1,640 & 1,640 & 1,640 & 1,640 & 1,640 & 1,640 & 1,640 \\
\hline 4 & 174 & 343 & 1,640 & 1,640 & 1,640 & 1,640 & 1,640 & 1,640 & 1,640 & 1,640 & 1,640 & 1,640 & 1,640 & 1,640 & 1,640 & 1,640 \\
\hline 2 & 217 & 390 & 1,635 & 1,635 & 1,635 & 1,635 & 1,635 & 1,635 & 1,635 & 1,635 & 1,635 & 1,635 & 1,635 & 1,635 & 1,635 & 1,635 \\
\hline 3 & 215 & 390 & 327 & 327 & 327 & 327 & 327 & 327 & 327 & 327 & 327 & 327 & 327 & 327 & 327 & 327 \\
\hline 3 & 172 & 329 & 136 & 136 & 136 & 136 & 136 & 136 & 136 & 136 & 136 & 136 & 136 & 136 & 136 & 136 \\
\hline 4 & 175 & 574 & 571 & 2,060 & 3,015 & 2,011 & 2,485 & 2,854 & 2,473 & 1,264 & 2,983 & 2,970 & 2,962 & 2,775 & 2,769 & 1,909 \\
\hline 4 & 176 & 572 & 2,819 & 2,364 & 2,249 & 2,309 & 583 & 22 & 2,012 & 2,696 & 2,406 & 2,931 & 2,983 & 2,159 & 2,591 & 2,716 \\
\hline 4 & 181 & 569 & 926 & 2,985 & 3,501 & 3,872 & 684 & 23 & 2,957 & 4,833 & 2,259 & 3,564 & 3,648 & 3,688 & 4,016 & 2,790 \\
\hline 4 & 176 & 572 & 1,055 & 3,525 & 984 & 3,218 & 3,015 & 1,645 & 0 & 1,533 & 3,207 & 3,194 & 1,584 & 0 & 1,272 & 1,993 \\
\hline 4 & 176 & 570 & 862 & 2,451 & 3,501 & 2,452 & 1,895 & 2,696 & 1,672 & 344 & 2,800 & 2,467 & 3,963 & 3,941 & 3,791 & 3,396 \\
\hline 4 & 177 & 572 & 787 & 2,162 & 1,280 & 2,735 & 2,358 & 2,037 & 1,842 & 2,363 & 1,363 & 2,152 & 2,188 & 2,375 & 2,514 & 2,243 \\
\hline
\end{tabular}


Table 5. Well pumpage used for the transient calibration simulation.-Continued

[L, layer number; $\mathrm{R}$, row number; $\mathrm{C}$, column number]

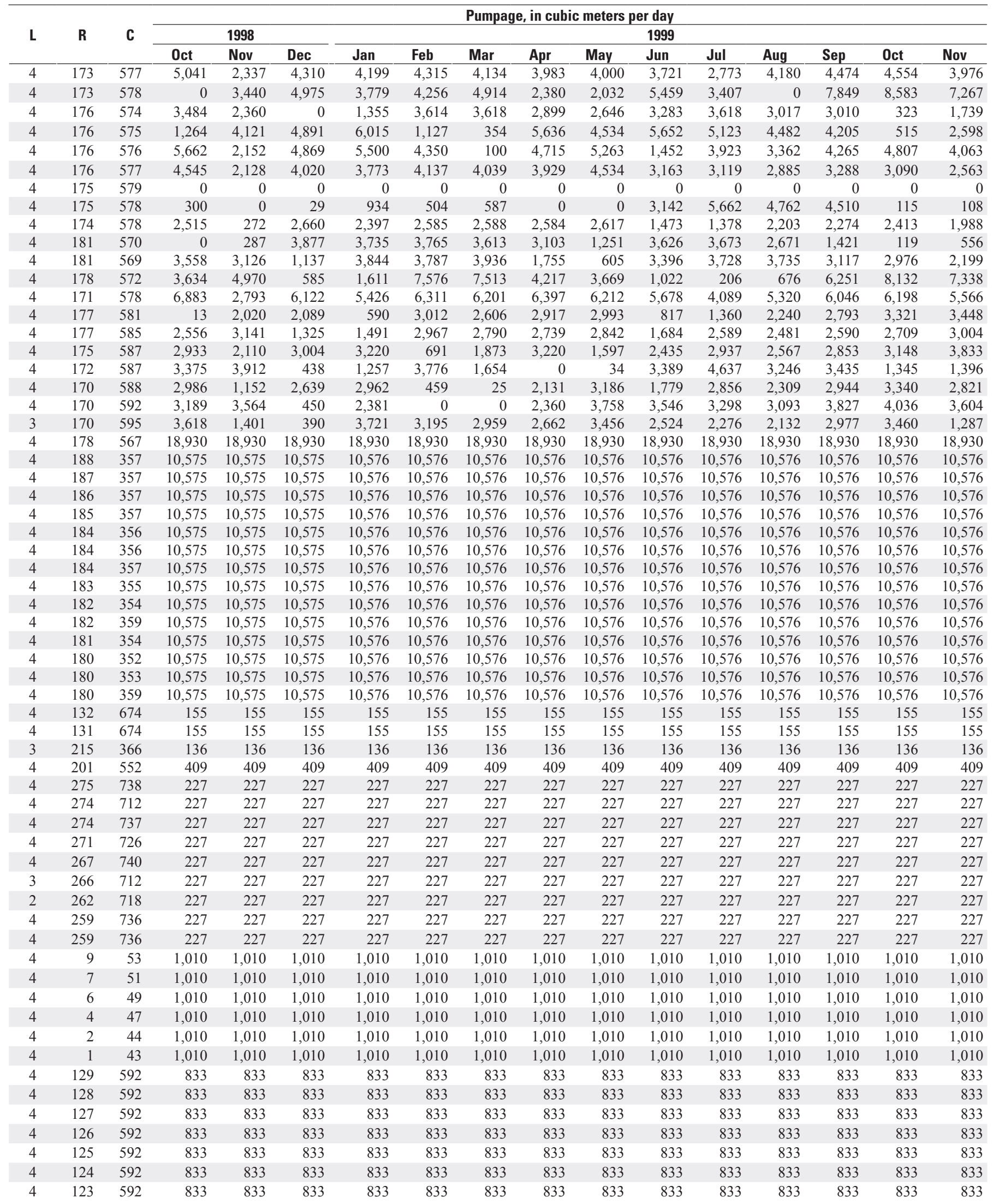


Table 5. Well pumpage used for the transient calibration simulation.-Continued

[L, layer number; $\mathrm{R}$, row number; $\mathrm{C}$, column number]

\begin{tabular}{|c|c|c|c|c|c|c|c|c|c|c|c|c|c|c|c|c|}
\hline \multirow{3}{*}{$\mathbf{L}$} & \multirow{3}{*}{$\mathbf{R}$} & \multirow{3}{*}{ C } & \multicolumn{14}{|c|}{ Pumpage, in cubic meters per day } \\
\hline & & & \multicolumn{3}{|c|}{1998} & \multicolumn{11}{|c|}{1999} \\
\hline & & & Oct & Nov & Dec & Jan & Feb & Mar & Apr & May & Jun & Jul & Aug & Sep & Oct & Nov \\
\hline 3 & 120 & 592 & 833 & 833 & 833 & 833 & 833 & 833 & 833 & 833 & 833 & 833 & 833 & 833 & 833 & 833 \\
\hline 3 & 119 & 592 & 833 & 833 & 833 & 833 & 833 & 833 & 833 & 833 & 833 & 833 & 833 & 833 & 833 & 833 \\
\hline 3 & 119 & 592 & 833 & 833 & 833 & 833 & 833 & 833 & 833 & 833 & 833 & 833 & 833 & 833 & 833 & 833 \\
\hline 4 & 139 & 239 & 2,110 & 2,110 & 2,110 & 2,110 & 2,110 & 2,110 & 2,110 & 2,110 & 2,110 & 2,110 & 2,110 & 2,110 & 2,110 & 2,110 \\
\hline 4 & 138 & 240 & 2,110 & 2,110 & 2,110 & 2,110 & 2,110 & 2,110 & 2,110 & 2,110 & 2,110 & 2,110 & 2,110 & 2,110 & 2,110 & 2,110 \\
\hline 4 & 138 & 241 & 2,110 & 2,110 & 2,110 & 2,110 & 2,110 & 2,110 & 2,110 & 2,110 & 2,110 & 2,110 & 2,110 & 2,110 & 2,110 & 2,110 \\
\hline 4 & 137 & 243 & 2,110 & 2,110 & 2,110 & 2,110 & 2,110 & 2,110 & 2,110 & 2,110 & 2,110 & 2,110 & 2,110 & 2,110 & 2,110 & 2,110 \\
\hline 4 & 231 & 367 & 1,740 & 1,740 & 1,740 & 1,830 & 1,830 & 1,830 & 1,830 & 1,830 & 1,830 & 1,830 & 1,830 & 1,830 & 1,830 & 1,830 \\
\hline 4 & 230 & 371 & 1,740 & 1,740 & 1,740 & 1,090 & 1,090 & 1,090 & 1,090 & 1,090 & 1,090 & 1,090 & 1,090 & 1,090 & 1,090 & 1,090 \\
\hline 4 & 230 & 376 & 1,740 & 1,740 & 1,740 & 1,090 & 1,090 & 1,090 & 1,090 & 1,090 & 1,090 & 1,090 & 1,090 & 1,090 & 1,090 & 1,090 \\
\hline 4 & 230 & 377 & 1,740 & 1,740 & 1,740 & 1,090 & 1,090 & 1,090 & 1,090 & 1,090 & 1,090 & 1,090 & 1,090 & 1,090 & 1,090 & 1,090 \\
\hline 4 & 228 & 375 & 1,740 & 1,740 & 1,740 & 1,090 & 1,090 & 1,090 & 1,090 & 1,090 & 1,090 & 1,090 & 1,090 & 1,090 & 1,090 & 1,090 \\
\hline 4 & 228 & 376 & 1,740 & 1,740 & 1,740 & 1,090 & 1,090 & 1,090 & 1,090 & 1,090 & 1,090 & 1,090 & 1,090 & 1,090 & 1,090 & 1,090 \\
\hline 4 & 226 & 375 & 1,740 & 1,740 & 1,740 & 1,090 & 1,090 & 1,090 & 1,090 & 1,090 & 1,090 & 1,090 & 1,090 & 1,090 & 1,090 & 1,090 \\
\hline 4 & 224 & 375 & 1,740 & 1,740 & 1,740 & 1,090 & 1,090 & 1,090 & 1,090 & 1,090 & 1,090 & 1,090 & 1,090 & 1,090 & 1,090 & 1,090 \\
\hline 4 & 208 & 364 & 2,000 & 2,000 & 2,000 & 2,208 & 2,208 & 2,208 & 2,208 & 2,208 & 2,208 & 2,208 & 2,208 & 2,208 & 2,208 & 2,208 \\
\hline 4 & 206 & 364 & 0 & 0 & 0 & 0 & 0 & 0 & 0 & 0 & 0 & 0 & 0 & 0 & 0 & 0 \\
\hline 4 & 205 & 363 & 2,208 & 2,208 & 2,208 & 2,208 & 2,208 & 2,208 & 2,208 & 2,208 & 2,208 & 2,208 & 2,208 & 2,208 & 2,208 & 2,208 \\
\hline 4 & 205 & 364 & 0 & 0 & 0 & 2,208 & 2,208 & 2,208 & 2,208 & 2,208 & 2,208 & 2,208 & 2,208 & 2,208 & 2,208 & 2,208 \\
\hline 4 & 204 & 364 & 2,208 & 2,208 & 2,208 & 2,208 & 2,208 & 2,208 & 2,208 & 2,208 & 2,208 & 2,208 & 2,208 & 2,208 & 2,208 & 2,208 \\
\hline 4 & 204 & 364 & 2,208 & 2,208 & 2,208 & 2,208 & 2,208 & 2,208 & 2,208 & 2,208 & 2,208 & 2,208 & 2,208 & 2,208 & 2,208 & 2,208 \\
\hline 4 & 204 & 364 & 2,208 & 2,208 & 2,208 & 0 & 0 & 0 & 0 & 0 & 0 & 0 & 0 & 0 & 0 & 0 \\
\hline 4 & 204 & 364 & 0 & 0 & 0 & 0 & 0 & 0 & 0 & 0 & 0 & 0 & 0 & 0 & 0 & 0 \\
\hline 4 & 192 & 329 & 545 & 545 & 545 & 545 & 545 & 545 & 545 & 545 & 545 & 545 & 545 & 545 & 545 & 545 \\
\hline 4 & 191 & 330 & 545 & 545 & 545 & 545 & 545 & 545 & 545 & 545 & 545 & 545 & 545 & 545 & 545 & 545 \\
\hline 4 & 211 & 376 & 136 & 136 & 136 & 136 & 136 & 136 & 136 & 136 & 136 & 136 & 136 & 136 & 136 & 136 \\
\hline 2 & 225 & 333 & 545 & 545 & 545 & 545 & 545 & 545 & 545 & 545 & 545 & 545 & 545 & 545 & 545 & 545 \\
\hline 2 & 222 & 335 & 545 & 545 & 545 & 545 & 545 & 545 & 545 & 545 & 545 & 545 & 545 & 545 & 545 & 545 \\
\hline 3 & 222 & 338 & 0 & 0 & 0 & 0 & 0 & 0 & 0 & 0 & 0 & 0 & 0 & 0 & 0 & 0 \\
\hline 2 & 219 & 335 & 545 & 545 & 545 & 545 & 545 & 545 & 545 & 545 & 545 & 545 & 545 & 545 & 545 & 545 \\
\hline 2 & 218 & 335 & 545 & 545 & 545 & 545 & 545 & 545 & 545 & 545 & 545 & 545 & 545 & 545 & 545 & 545 \\
\hline 2 & 217 & 341 & 0 & 0 & 0 & 0 & 0 & 0 & 0 & 0 & 0 & 0 & 0 & 0 & 0 & 0 \\
\hline 3 & 216 & 337 & 545 & 545 & 545 & 545 & 545 & 545 & 545 & 545 & 545 & 545 & 545 & 545 & 545 & 545 \\
\hline 3 & 210 & 345 & 545 & 545 & 545 & 545 & 545 & 545 & 545 & 545 & 545 & 545 & 545 & 545 & 545 & 545 \\
\hline 4 & 204 & 349 & 545 & 545 & 545 & 545 & 545 & 545 & 545 & 545 & 545 & 545 & 545 & 545 & 545 & 545 \\
\hline 4 & 83 & 868 & 1,023 & 1,023 & 1,023 & 1,023 & 1,023 & 1,023 & 1,023 & 1,023 & 1,023 & 1,023 & 1,023 & 1,023 & 1,023 & 1,023 \\
\hline 4 & 83 & 869 & 1,023 & 1,023 & 1,023 & 1,023 & 1,023 & 1,023 & 1,023 & 1,023 & 1,023 & 1,023 & 1,023 & 1,023 & 1,023 & 1,023 \\
\hline 4 & 82 & 872 & 1,023 & 1,023 & 1,023 & 1,023 & 1,023 & 1,023 & 1,023 & 1,023 & 1,023 & 1,023 & 1,023 & 1,023 & 1,023 & 1,023 \\
\hline 4 & 82 & 874 & 1,023 & 1,023 & 1,023 & 1,023 & 1,023 & 1,023 & 1,023 & 1,023 & 1,023 & 1,023 & 1,023 & 1,023 & 1,023 & 1,023 \\
\hline 4 & 80 & 872 & 1,023 & 1,023 & 1,023 & 1,023 & 1,023 & 1,023 & 1,023 & 1,023 & 1,023 & 1,023 & 1,023 & 1,023 & 1,023 & 1,023 \\
\hline 4 & 199 & 324 & 545 & 545 & 545 & 545 & 545 & 545 & 545 & 545 & 545 & 545 & 545 & 545 & 545 & 545 \\
\hline 3 & 209 & 330 & 1,090 & 1,090 & 1,090 & 1,090 & 1,090 & 1,090 & 1,090 & 1,090 & 1,090 & 1,090 & 1,090 & 1,090 & 1,090 & 1,090 \\
\hline 4 & 201 & 391 & 273 & 273 & 273 & 273 & 273 & 273 & 273 & 273 & 273 & 273 & 273 & 273 & 273 & 273 \\
\hline 4 & 198 & 365 & 545 & 545 & 545 & 545 & 545 & 545 & 545 & 545 & 545 & 545 & 545 & 545 & 545 & 545 \\
\hline 4 & 101 & 763 & 1,892 & 1,892 & 1,892 & 1,892 & 1,892 & 1,892 & 1,892 & 1,892 & 1,892 & 1,892 & 1,892 & 1,892 & 1,892 & 1,892 \\
\hline 4 & 100 & 763 & 1,892 & 1,892 & 1,892 & 1,892 & 1,892 & 1,892 & 1,892 & 1,892 & 1,892 & 1,892 & 1,892 & 1,892 & 1,892 & 1,892 \\
\hline 4 & 99 & 762 & 1,892 & 1,892 & 1,892 & 1,892 & 1,892 & 1,892 & 1,892 & 1,892 & 1,892 & 1,892 & 1,892 & 1,892 & 1,892 & 1,892 \\
\hline 3 & 274 & 730 & 491 & 491 & 491 & 491 & 491 & 491 & 491 & 491 & 491 & 491 & 491 & 491 & 491 & 491 \\
\hline 3 & 269 & 720 & 491 & 491 & 491 & 491 & 491 & 491 & 491 & 491 & 491 & 491 & 491 & 491 & 491 & 491 \\
\hline 4 & 266 & 739 & 491 & 491 & 491 & 491 & 491 & 491 & 491 & 491 & 491 & 491 & 491 & 491 & 491 & 491 \\
\hline 4 & 265 & 730 & 491 & 491 & 491 & 491 & 491 & 491 & 491 & 491 & 491 & 491 & 491 & 491 & 491 & 491 \\
\hline
\end{tabular}


Table 7. 2007 average annual well pumpage for Independence and other supply wells used for the steady-state 2007 base simulation.

[ID, identifier; $\mathrm{L}$, layer number; $\mathrm{R}$, row number; $\mathrm{C}$, column number; $\mathrm{m}^{3} /$ day, cubic meters per day]

\begin{tabular}{|c|c|c|c|c|c|c|c|c|c|}
\hline \multicolumn{10}{|c|}{ Independence supply wells } \\
\hline $1 \mathrm{~A}$ & 4 & 175 & 574 & 1,714 & 22 & 4 & 175 & 578 & 2,313 \\
\hline $2 \mathrm{~A}$ & 4 & 176 & 572 & 2,263 & 23 & 4 & 174 & 578 & 1,998 \\
\hline 4 & 4 & 176 & 572 & 1,475 & 27 & 4 & 181 & 569 & 1,228 \\
\hline $5 \mathrm{~A}$ & 4 & 176 & 570 & 2,921 & 30 & 4 & 178 & 572 & 1,295 \\
\hline 6 & 4 & 177 & 572 & 0 & 32 & 4 & 171 & 578 & 3,819 \\
\hline 9 & 4 & 180 & 571 & 3,662 & 35 & 4 & 175 & 587 & 768 \\
\hline 10 & 4 & 179 & 573 & 7,709 & 36 & 4 & 172 & 587 & 1,031 \\
\hline 11 & 4 & 178 & 573 & 468 & 38 & 4 & 170 & 588 & 2,371 \\
\hline 12 & 4 & 180 & 570 & 2,753 & 39 & 4 & 170 & 592 & 1,850 \\
\hline 13 & 4 & 174 & 575 & 3,550 & 40 & 3 & 170 & 595 & 2,181 \\
\hline 14 & 4 & 174 & 575 & 1,818 & 41 & 4 & 178 & 567 & 18,930 \\
\hline 20 & 4 & 176 & 577 & 4,548 & 47 & 4 & 161 & 577 & 8,946 \\
\hline 21 & 4 & 175 & 579 & 0 & 48 & 4 & 158 & 577 & 11,423 \\
\hline
\end{tabular}

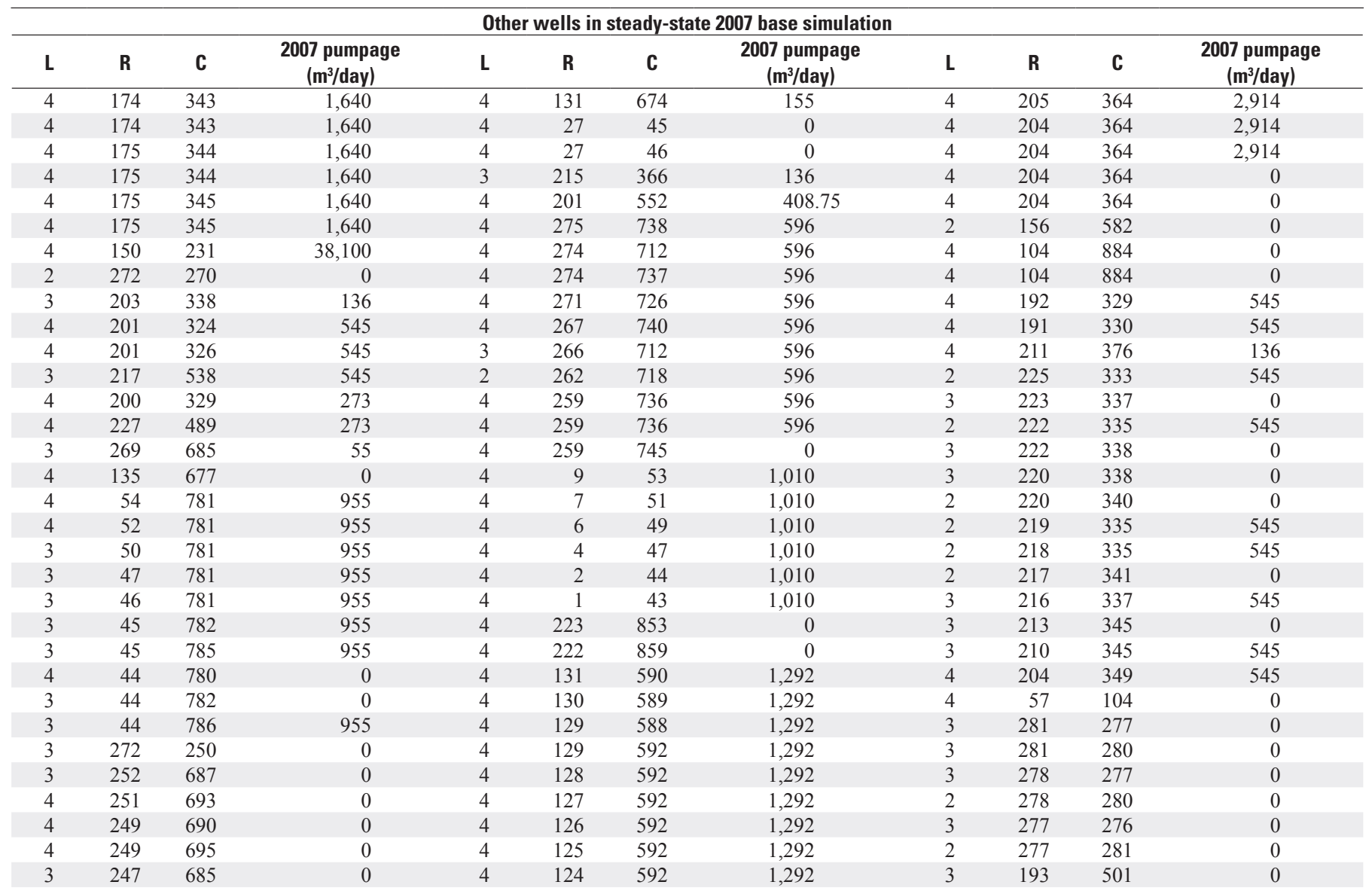


Table 7. 2007 average annual well pumpage for Independence and other supply wells used for the steady-state 2007 base simulation. -Continued

[ID, identifier; L, layer number; R, row number; C, column number; $\mathrm{m}^{3} / \mathrm{day}$, cubic meters per day]

\begin{tabular}{|c|c|c|c|c|c|c|c|c|c|c|c|}
\hline \multicolumn{12}{|c|}{ Other wells in steady-state 2007 base simulation } \\
\hline $\mathbf{L}$ & $\mathbf{R}$ & C & $\begin{array}{c}2007 \text { pumpage } \\
\left(\mathrm{m}^{3} / \text { day }\right)\end{array}$ & $\mathbf{L}$ & $\mathbf{R}$ & $\mathbf{C}$ & $\begin{array}{c}2007 \text { pumpage } \\
\left(\mathrm{m}^{3} / \text { day }\right)\end{array}$ & $\mathbf{L}$ & $\mathbf{R}$ & C & $\begin{array}{c}2007 \text { pumpage } \\
\left(\mathrm{m}^{3} / \text { day }\right)\end{array}$ \\
\hline 3 & 78 & 680 & 0 & 4 & 123 & 592 & 1,292 & 4 & 83 & 868 & 1,023 \\
\hline 3 & 77 & 680 & 0 & 4 & 122 & 592 & 0 & 4 & 83 & 869 & 1,023 \\
\hline 3 & 76 & 680 & 0 & 3 & 120 & 592 & 1,292 & 4 & 82 & 872 & 1,023 \\
\hline 4 & 188 & 357 & 10,576 & 3 & 119 & 592 & 1,292 & 4 & 82 & 874 & 1,023 \\
\hline 4 & 187 & 357 & 10,576 & 3 & 119 & 592 & 1,292 & 4 & 80 & 872 & 1,023 \\
\hline 4 & 186 & 357 & 10,576 & 4 & 139 & 239 & 2,110 & 4 & 199 & 324 & 545 \\
\hline 4 & 185 & 357 & 10,576 & 4 & 138 & 240 & 2,110 & 4 & 228 & 364 & 0 \\
\hline 4 & 184 & 356 & 10,576 & 4 & 138 & 241 & 2,110 & 3 & 209 & 330 & 1,090 \\
\hline 4 & 184 & 356 & 10,576 & 4 & 137 & 243 & 2,110 & 4 & 148 & 141 & 0 \\
\hline 4 & 184 & 357 & 10,576 & 2 & 155 & 297 & 0 & 2 & 104 & 92 & 0 \\
\hline 4 & 225 & 375 & 0 & 4 & 211 & 432 & 0 & 4 & 201 & 391 & 273 \\
\hline 2 & 217 & 390 & 1,275 & 4 & 231 & 367 & 3,286 & 4 & 198 & 364 & 0 \\
\hline 3 & 216 & 390 & 0 & 4 & 230 & 371 & 3,286 & 4 & 198 & 365 & 545 \\
\hline 3 & 215 & 390 & 327 & 4 & 230 & 376 & 3,286 & 4 & 101 & 763 & 1,892 \\
\hline 3 & 172 & 329 & 136 & 4 & 230 & 377 & 3,286 & 4 & 100 & 763 & 1,892 \\
\hline 4 & 183 & 355 & 10,576 & 4 & 228 & 375 & 3,286 & 4 & 100 & 763 & 1,892 \\
\hline 4 & 182 & 354 & 10,576 & 4 & 228 & 376 & 3,286 & 4 & 99 & 762 & 1,892 \\
\hline 4 & 182 & 359 & 10,576 & 4 & 226 & 375 & 3,286 & 4 & 99 & 766 & 5,000 \\
\hline 4 & 181 & 354 & 10,576 & 4 & 224 & 375 & 3,286 & 3 & 274 & 730 & 490.5 \\
\hline 4 & 180 & 352 & 10,576 & 4 & 208 & 364 & 0 & 3 & 269 & 720 & 490.5 \\
\hline 4 & 180 & 353 & 10,576 & 4 & 208 & 364 & 2,914 & 4 & 266 & 739 & 490.5 \\
\hline 4 & 180 & 359 & 10,576 & 4 & 206 & 364 & 0 & 4 & 265 & 730 & 490.5 \\
\hline 4 & 132 & 674 & 155 & 4 & 205 & 363 & 2,914 & & & & \\
\hline
\end{tabular}


Table 21. Results of enzyme-linked immunosorbent assay (ELISA) analyses of total BTEX (benzene, toluene, ethylbenzene, and xylene), alachlor, and atrazine for water samples from all monitoring wells.

[a,b,c in identifier indicates relative depth of the well in each nest from "a" the deepest to "c" the shallowest. For well nest 4, 4a is deepest, 4c is intermediate, and $4 \mathrm{~b}$ is shallowest; $\mathrm{mg} / \mathrm{L}$, milligrams per liter; $\mu \mathrm{g} / \mathrm{L}$, micrograms per liter; $<$, less than; -, not analyzed; IND, combined well-field sample]

\begin{tabular}{|c|c|c|c|c|}
\hline $\begin{array}{c}\text { Well identifier } \\
\text { (fig. 2) }\end{array}$ & Date & $\begin{array}{c}\text { BTEX } \\
\text { (mg/L) }\end{array}$ & $\begin{array}{c}\text { Alachlor } \\
(\mu \mathrm{g} / \mathrm{L})\end{array}$ & $\begin{array}{c}\text { Atrazine } \\
(\mu \mathrm{g} / \mathrm{L})\end{array}$ \\
\hline \multirow{5}{*}{$1 \mathrm{a}$} & $8 / 30 / 2000$ & $<.09$ & - & - \\
\hline & 7/17/2001 & $<.09$ & $<.05$ & $<.05$ \\
\hline & $6 / 2 / 2004$ & $<.09$ & $<.05$ & $<.05$ \\
\hline & $6 / 20 / 2005$ & $<.09$ & $<.05$ & .15 \\
\hline & $6 / 20 / 2006$ & .08 & $<.05$ & $<.05$ \\
\hline \multirow[t]{7}{*}{$1 \mathrm{~b}$} & $5 / 27 / 1999$ & $<.09$ & $<.05$ & $<.05$ \\
\hline & 8/25/1999 & - & $<.05$ & $<.05$ \\
\hline & $11 / 19 / 1999$ & - & $<.05$ & $<.05$ \\
\hline & $2 / 25 / 2000$ & - & $<.05$ & - \\
\hline & $8 / 30 / 2000$ & $<.09$ & $<.05$ & $<.05$ \\
\hline & $8 / 27 / 2002$ & $<.09$ & $<.05$ & - \\
\hline & $6 / 20 / 2005$ & $<.09$ & $<.05$ & .06 \\
\hline \multirow{4}{*}{$2 a$} & $6 / 20 / 2005$ & $<.09$ & $<.05$ & $<.05$ \\
\hline & $6 / 21 / 2006$ & .03 & $<.05$ & $<.05$ \\
\hline & $7 / 18 / 2007$ & $<.09$ & $<.05$ & $<.05$ \\
\hline & $7 / 8 / 2008$ & $<.09$ & $<.05$ & $<.05$ \\
\hline \multirow{10}{*}{$2 b$} & 4/20/1999 & - & $<.05$ & $<.05$ \\
\hline & $5 / 21 / 1999$ & $<.09$ & $<.05$ & $<.05$ \\
\hline & $6 / 21 / 1999$ & - & $<.05$ & $<.05$ \\
\hline & $8 / 25 / 1999$ & $<.09$ & $<.05$ & $<.05$ \\
\hline & $10 / 27 / 1999$ & - & $<.05$ & $<.05$ \\
\hline & $11 / 19 / 1999$ & $<.09$ & $<.05$ & $<.05$ \\
\hline & $12 / 14 / 1999$ & - & $<.05$ & $<.05$ \\
\hline & $2 / 28 / 2000$ & $<.09$ & $<.05$ & - \\
\hline & $3 / 31 / 2000$ & - & $<.05$ & - \\
\hline & $7 / 13 / 2000$ & - & $<.05$ & $<.05$ \\
\hline \multirow{5}{*}{$3 a$} & $8 / 28 / 2002$ & $<.09$ & $<.05$ & - \\
\hline & $6 / 3 / 2004$ & $<.09$ & $<.05$ & $<.05$ \\
\hline & $6 / 14 / 2005$ & $<.09$ & $<.05$ & $<.05$ \\
\hline & $6 / 21 / 2007$ & $<.09$ & $<.05$ & $<.05$ \\
\hline & $5 / 29 / 2008$ & $<.09$ & $<.05$ & $<.05$ \\
\hline \multirow[t]{8}{*}{$3 b$} & $5 / 18 / 1999$ & $<.09$ & $<.05$ & $<.05$ \\
\hline & $8 / 25 / 1999$ & - & $<.05$ & $<.05$ \\
\hline & $11 / 22 / 1999$ & - & $<.05$ & .07 \\
\hline & $2 / 28 / 2000$ & - & $<.05$ & - \\
\hline & $8 / 30 / 2000$ & $<.09$ & $<.05$ & $<.05$ \\
\hline & $8 / 28 / 2002$ & $<.09$ & $<.05$ & - \\
\hline & $6 / 14 / 2005$ & $<.09$ & $<.05$ & $<.05$ \\
\hline & $5 / 29 / 2008$ & $<.09$ & $<.05$ & $<.05$ \\
\hline $4 a$ & $8 / 28 / 2002$ & $<.09$ & $<.05$ & - \\
\hline \multirow{7}{*}{$4 \mathrm{~b}$} & $4 / 20 / 1999$ & - & $<.05$ & $<.05$ \\
\hline & $5 / 18 / 1999$ & $<.09$ & $<.05$ & $<.05$ \\
\hline & 9/9/1999 & - & $<.05$ & $<.05$ \\
\hline & 10/27/1999 & - & $<.05$ & $<.05$ \\
\hline & $11 / 22 / 1999$ & - & $<.05$ & .08 \\
\hline & $2 / 25 / 2000$ & - & $<.05$ & - \\
\hline & $3 / 31 / 2000$ & - & $<.05$ & - \\
\hline
\end{tabular}


Table 21. Results of enzyme-linked immunosorbent assay (ELISA) analyses of total BTEX (benzene, toluene, ethylbenzene, and xylene), alachlor, and atrazine for water samples from all monitoring wells.-Continued

[a,b,c in identifier indicates relative depth of the well in each nest from "a" the deepest to "c" the shallowest. For well nest 4, 4a is deepest, 4c is intermediate, and $4 \mathrm{~b}$ is shallowest; $\mathrm{mg} / \mathrm{L}$, milligrams per liter; $\mu \mathrm{g} / \mathrm{L}$, micrograms per liter; <, less than; -, not analyzed; IND, combined well-field sample]

\begin{tabular}{|c|c|c|c|c|}
\hline $\begin{array}{c}\text { Well identifier } \\
\text { (fig. 2) }\end{array}$ & Date & $\begin{array}{c}\text { BTEX } \\
\text { (mg/L) }\end{array}$ & $\begin{array}{c}\text { Alachlor } \\
\text { ( } \mu \mathrm{g} / \mathrm{L})\end{array}$ & $\begin{array}{c}\text { Atrazine } \\
(\mu \mathrm{g} / \mathrm{L})\end{array}$ \\
\hline & $7 / 17 / 2001$ & $<.09$ & $<.05$ & $<.05$ \\
\hline & $8 / 28 / 2002$ & $<.09$ & $<.05$ & - \\
\hline & $6 / 14 / 2005$ & $<.09$ & $<.05$ & $<.05$ \\
\hline & $6 / 20 / 2007$ & $<.09$ & $<.05$ & $<.05$ \\
\hline & $7 / 16 / 2008$ & .05 & $<.05$ & $<.05$ \\
\hline \multirow{6}{*}{$4 c$} & $8 / 31 / 2000$ & - & $<.05$ & $<.05$ \\
\hline & 7/17/2001 & $<.09$ & $<.05$ & $<.05$ \\
\hline & $6 / 15 / 2004$ & $<.09$ & $<.05$ & $<.05$ \\
\hline & $6 / 14 / 2005$ & $<.09$ & $<.05$ & .09 \\
\hline & $6 / 20 / 2007$ & $<.09$ & $<.05$ & $<.05$ \\
\hline & $7 / 16 / 2008$ & .02 & $<.05$ & $<.05$ \\
\hline $5 a$ & $5 / 26 / 1999$ & $<.09$ & .09 & .19 \\
\hline $5 \mathrm{a}$ & $7 / 15 / 2008$ & $<.09$ & $<.05$ & $<.05$ \\
\hline \multirow{8}{*}{$5 b$} & 5/26/1999 & - & .12 & $<.05$ \\
\hline & $8 / 25 / 1999$ & - & $<.05$ & $<.05$ \\
\hline & 11/19/1999 & - & $<.05$ & .10 \\
\hline & $2 / 28 / 2000$ & - & $<.05$ & - \\
\hline & $8 / 30 / 2000$ & - & $<.05$ & - \\
\hline & $8 / 28 / 2002$ & - & $<.05$ & - \\
\hline & 6/14/2005 & - & $<.05$ & $<.05$ \\
\hline & $7 / 15 / 2008$ & - & $<.05$ & $<.05$ \\
\hline \multirow[t]{4}{*}{$6 a$} & $5 / 26 / 1999$ & $<.09$ & $<.05$ & $<.05$ \\
\hline & 9/10/1999 & $<.09$ & $<.05$ & $<.05$ \\
\hline & $11 / 22 / 1999$ & $<.09$ & $<.05$ & .07 \\
\hline & $2 / 25 / 2000$ & $<.09$ & $<.05$ & - \\
\hline \multirow{6}{*}{$7 a$} & $11 / 20 / 1999$ & - & $<.05$ & .09 \\
\hline & $2 / 28 / 2000$ & - & $<.05$ & - \\
\hline & $8 / 30 / 2000$ & - & $<.05$ & - \\
\hline & 8/29/2002 & - & $<.05$ & - \\
\hline & $6 / 10 / 2005$ & $<.09$ & $<.05$ & .07 \\
\hline & $6 / 5 / 2008$ & - & $<.05$ & $<.05$ \\
\hline \multirow[t]{7}{*}{$7 b$} & 5/13/1999 & $<.09$ & .18 & $<.05$ \\
\hline & $7 / 17 / 2001$ & $<.09$ & $<.05$ & $<.05$ \\
\hline & 8/29/2002 & $<.09$ & $<.05$ & - \\
\hline & $6 / 14 / 2004$ & $<.09$ & $<.05$ & $<.05$ \\
\hline & $6 / 10 / 2005$ & $<.09$ & $<.05$ & .07 \\
\hline & $6 / 20 / 2007$ & $<.09$ & $<.05$ & $<.05$ \\
\hline & $6 / 5 / 2008$ & $<.09$ & $<.05$ & $<.05$ \\
\hline \multirow{8}{*}{$7 \mathrm{c}$} & 5/13/1999 & $<.09$ & $<.05$ & $<.05$ \\
\hline & 9/10/1999 & - & $<.05$ & $<.05$ \\
\hline & $11 / 20 / 1999$ & - & $<.05$ & .08 \\
\hline & $2 / 28 / 2000$ & - & $<.05$ & - \\
\hline & $8 / 30 / 2000$ & - & $<.05$ & $<.05$ \\
\hline & $8 / 29 / 2002$ & $<.09$ & $<.05$ & - \\
\hline & $6 / 10 / 2005$ & $<.09$ & $<.05$ & $<.05$ \\
\hline & $6 / 5 / 2008$ & $<.09$ & $<.05$ & $<.05$ \\
\hline
\end{tabular}


Table 21. Results of enzyme-linked immunosorbent assay (ELISA) analyses of total BTEX (benzene, toluene, ethylbenzene, and xylene), alachlor, and atrazine for water samples from all monitoring wells.-Continued

[a,b,c in identifier indicates relative depth of the well in each nest from "a" the deepest to "c" the shallowest. For well nest 4, 4a is deepest, 4c is intermediate, and $4 \mathrm{~b}$ is shallowest; $\mathrm{mg} / \mathrm{L}$, milligrams per liter; $\mu \mathrm{g} / \mathrm{L}$, micrograms per liter; $<$, less than; -, not analyzed; IND, combined well-field sample]

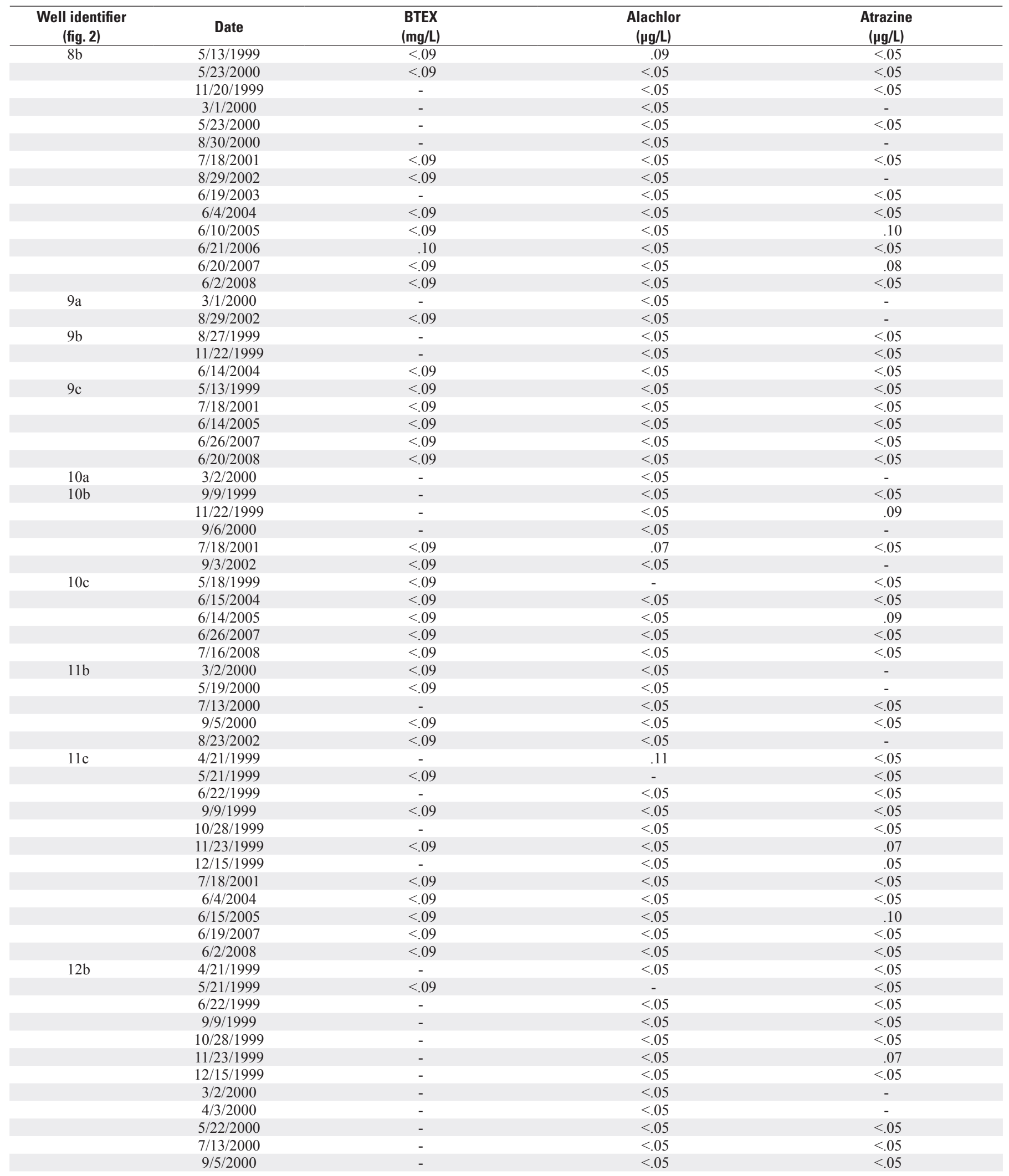


Table 21. Results of enzyme-linked immunosorbent assay (ELISA) analyses of total BTEX (benzene, toluene, ethylbenzene, and xylene), alachlor, and atrazine for water samples from all monitoring wells.-Continued

$[a, b, c$ in identifier indicates relative depth of the well in each nest from "a" the deepest to "c" the shallowest. For well nest 4, 4a is deepest, 4c is intermediate, and $4 \mathrm{~b}$ is shallowest; $\mathrm{mg} / \mathrm{L}$, milligrams per liter; $\mu \mathrm{g} / \mathrm{L}$, micrograms per liter; <, less than; -, not analyzed; IND, combined well-field sample]

\begin{tabular}{|c|c|c|c|c|}
\hline $\begin{array}{l}\text { Well identifier } \\
\text { (fig. 2) }\end{array}$ & Date & $\begin{array}{c}\text { BTEX } \\
\text { (mg/L) }\end{array}$ & $\begin{array}{c}\text { Alachlor } \\
(\mu \mathrm{g} / \mathrm{L})\end{array}$ & $\begin{array}{c}\text { Atrazine } \\
(\mu \mathrm{g} / \mathrm{L})\end{array}$ \\
\hline & $8 / 23 / 2002$ & - & $<.05$ & - \\
\hline & $6 / 18 / 2003$ & - & $<.05$ & $<.05$ \\
\hline & $6 / 15 / 2005$ & - & $<.05$ & $<.05$ \\
\hline & $6 / 22 / 2006$ & $<.09$ & $<.05$ & $<.05$ \\
\hline & $6 / 19 / 2007$ & - & $<.05$ & $<.05$ \\
\hline \multirow{7}{*}{$13 b$} & 8/23/1999 & - & $<.05$ & $<.05$ \\
\hline & $11 / 23 / 1999$ & - & $<.05$ & .07 \\
\hline & $3 / 1 / 2000$ & - & $<.05$ & - \\
\hline & 9/7/2000 & - & $<.05$ & $<.05$ \\
\hline & $8 / 23 / 2002$ & - & $<.05$ & - \\
\hline & $6 / 15 / 2005$ & - & $<.05$ & $<.05$ \\
\hline & $5 / 30 / 2008$ & - & $<.05$ & $<.05$ \\
\hline \multirow{3}{*}{$14 \mathrm{~b}$} & $9 / 6 / 2000$ & - & $<.05$ & $<.05$ \\
\hline & $8 / 23 / 2002$ & - & $<.05$ & - \\
\hline & $6 / 18 / 2003$ & - & $<.05$ & $<.05$ \\
\hline \multirow[t]{9}{*}{$14 \mathrm{c}$} & $5 / 12 / 1999$ & - & - & $<.05$ \\
\hline & 8/23/1999 & - & $<.05$ & $<.05$ \\
\hline & $11 / 23 / 1999$ & - & $<.05$ & .06 \\
\hline & $3 / 1 / 2000$ & - & $<.05$ & - \\
\hline & $7 / 18 / 2001$ & - & $<.05$ & $<.05$ \\
\hline & $6 / 4 / 2004$ & - & $<.05$ & $<.05$ \\
\hline & $6 / 15 / 2005$ & - & $<.05$ & .06 \\
\hline & $6 / 19 / 2007$ & - & $<.05$ & $<.05$ \\
\hline & $5 / 30 / 2008$ & - & $<.05$ & $<.05$ \\
\hline $15 \mathrm{a}$ & $8 / 23 / 1999$ & - & .11 & $<.05$ \\
\hline \multirow{5}{*}{$15 \mathrm{~b}$} & $12 / 15 / 1999$ & - & .21 & .20 \\
\hline & $2 / 25 / 2000$ & - & .09 & - \\
\hline & $3 / 31 / 2000$ & - & .08 & - \\
\hline & $5 / 22 / 2000$ & - & $<.05$ & .15 \\
\hline & $7 / 13 / 2000$ & - & $<.05$ & .25 \\
\hline \multirow[t]{9}{*}{$15 b$} & $9 / 7 / 2000$ & - & .05 & .17 \\
\hline & $7 / 19 / 2001$ & - & $<.05$ & $<.05$ \\
\hline & $8 / 23 / 2002$ & - & .05 & - \\
\hline & $6 / 18 / 2003$ & - & $<.05$ & $<.05$ \\
\hline & $6 / 4 / 2004$ & - & $<.05$ & $<.05$ \\
\hline & $6 / 15 / 2005$ & - & .09 & $<.05$ \\
\hline & $6 / 22 / 2006$ & - & .05 & $<.05$ \\
\hline & $6 / 19 / 2007$ & - & $<.05$ & .19 \\
\hline & $5 / 30 / 2008$ & - & $<.05$ & $<.05$ \\
\hline \multirow[t]{7}{*}{$16 a$} & $5 / 5 / 1999$ & .03 & - & $<.05$ \\
\hline & $8 / 27 / 1999$ & - & $<.05$ & $<.05$ \\
\hline & $11 / 24 / 1999$ & - & $<.05$ & .06 \\
\hline & $2 / 23 / 2000$ & - & $<.05$ & - \\
\hline & $8 / 28 / 2000$ & - & $<.05$ & - \\
\hline & $7 / 9 / 2001$ & $<.09$ & $<.05$ & $<.05$ \\
\hline & $8 / 20 / 2002$ & - & $<.05$ & - \\
\hline
\end{tabular}


Table 21. Results of enzyme-linked immunosorbent assay (ELISA) analyses of total BTEX (benzene, toluene, ethylbenzene, and xylene), alachlor, and atrazine for water samples from all monitoring wells.-Continued

[a,b,c in identifier indicates relative depth of the well in each nest from "a" the deepest to "c" the shallowest. For well nest 4, 4a is deepest, 4c is intermediate, and $4 \mathrm{~b}$ is shallowest; $\mathrm{mg} / \mathrm{L}$, milligrams per liter; $\mu \mathrm{g} / \mathrm{L}$, micrograms per liter; <, less than; -, not analyzed; IND, combined well-field sample]

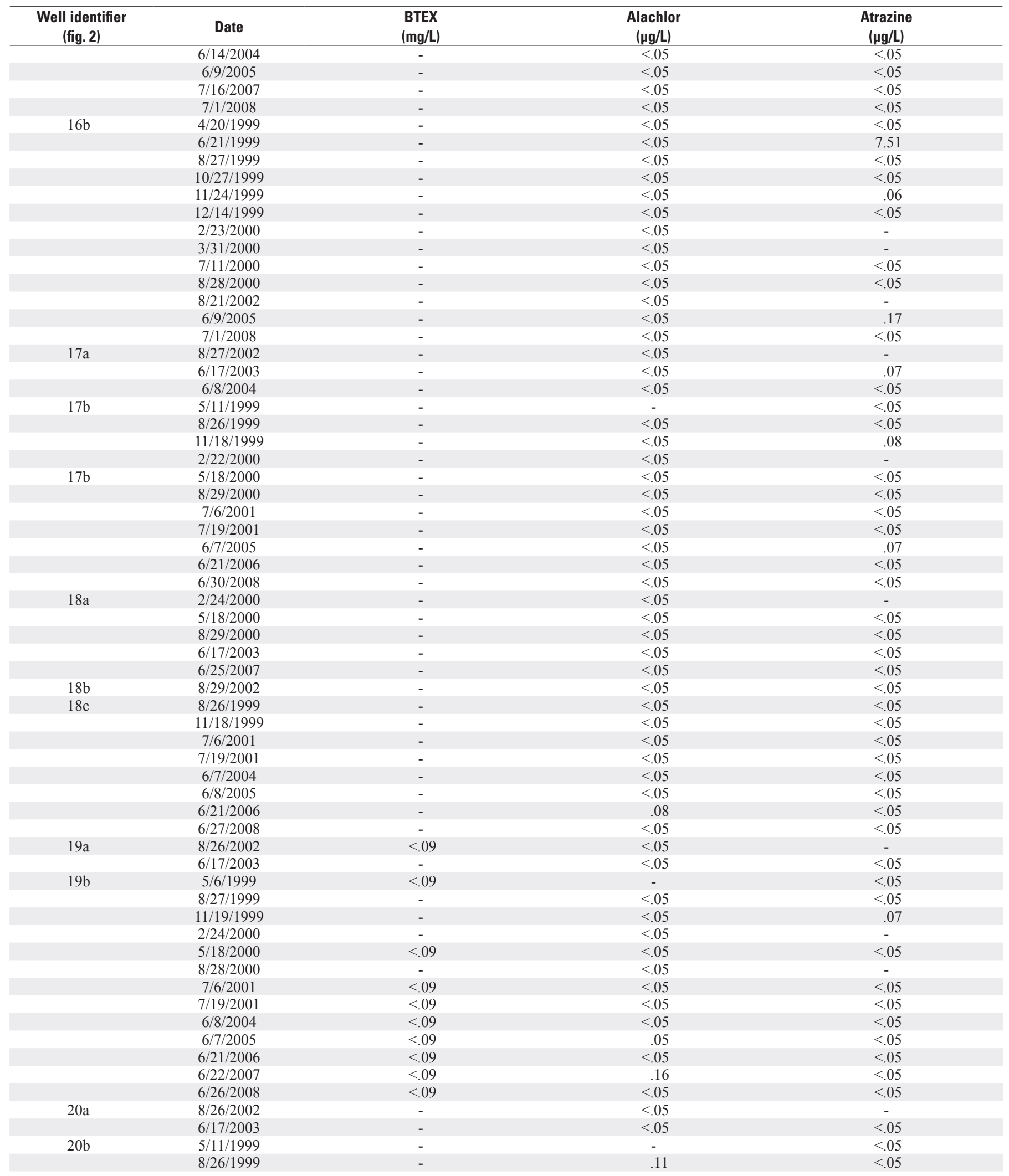


Table 21. Results of enzyme-linked immunosorbent assay (ELISA) analyses of total BTEX (benzene, toluene, ethylbenzene, and xylene), alachlor, and atrazine for water samples from all monitoring wells.-Continued

[a,b,c in identifier indicates relative depth of the well in each nest from "a" the deepest to "c" the shallowest. For well nest 4, 4a is deepest, 4c is intermediate, and $4 \mathrm{~b}$ is shallowest; $\mathrm{mg} / \mathrm{L}$, milligrams per liter; $\mu \mathrm{g} / \mathrm{L}$, micrograms per liter; <, less than; -, not analyzed; IND, combined well-field sample]

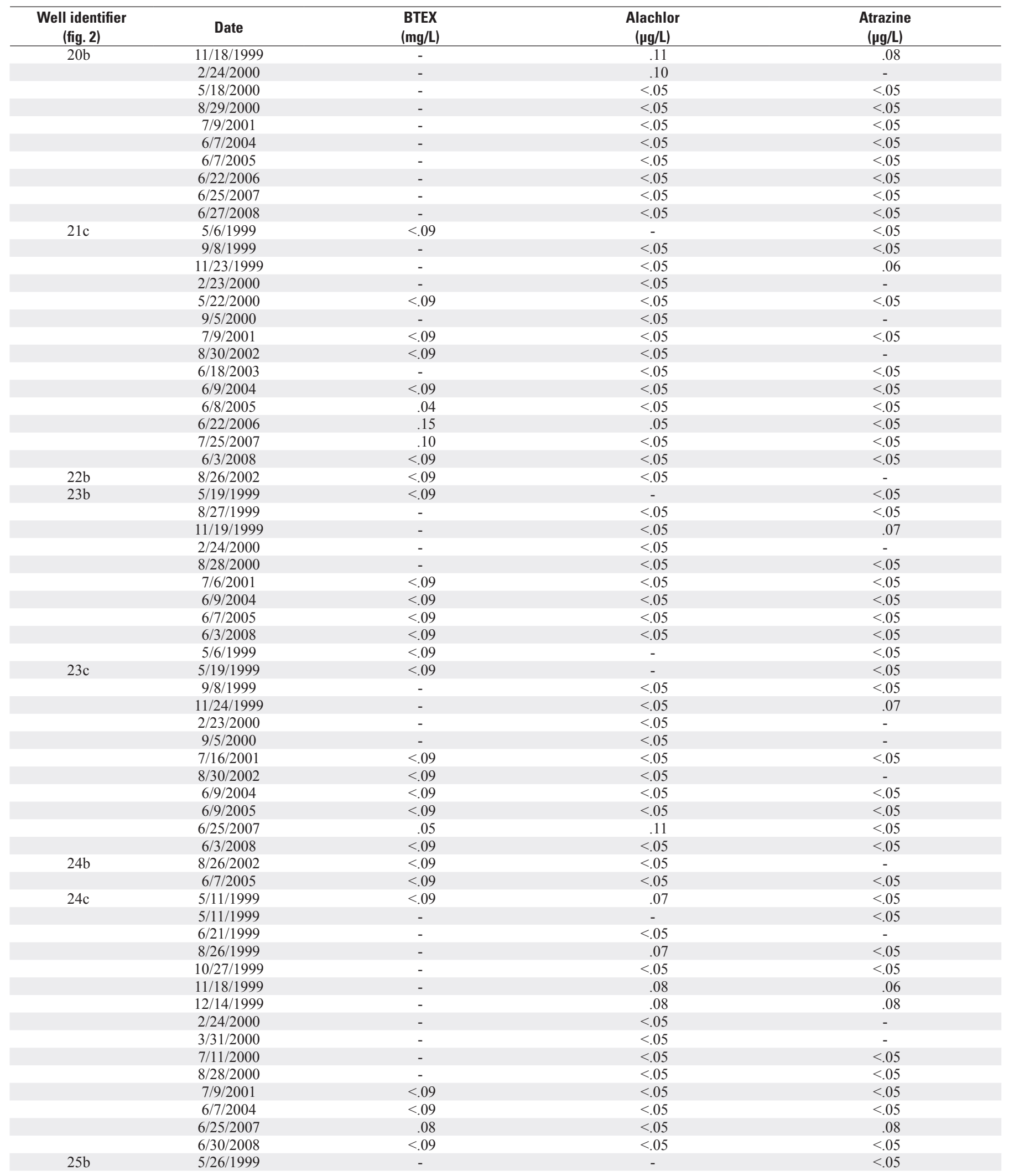


Table 21. Results of enzyme-linked immunosorbent assay (ELISA) analyses of total BTEX (benzene, toluene, ethylbenzene, and xylene), alachlor, and atrazine for water samples from all monitoring wells.-Continued

[a,b,c in identifier indicates relative depth of the well in each nest from "a" the deepest to "c" the shallowest. For well nest 4, 4a is deepest, 4c is intermediate, and $4 \mathrm{~b}$ is shallowest; $\mathrm{mg} / \mathrm{L}$, milligrams per liter; $\mu \mathrm{g} / \mathrm{L}$, micrograms per liter; $<$, less than; -, not analyzed; IND, combined well-field sample]

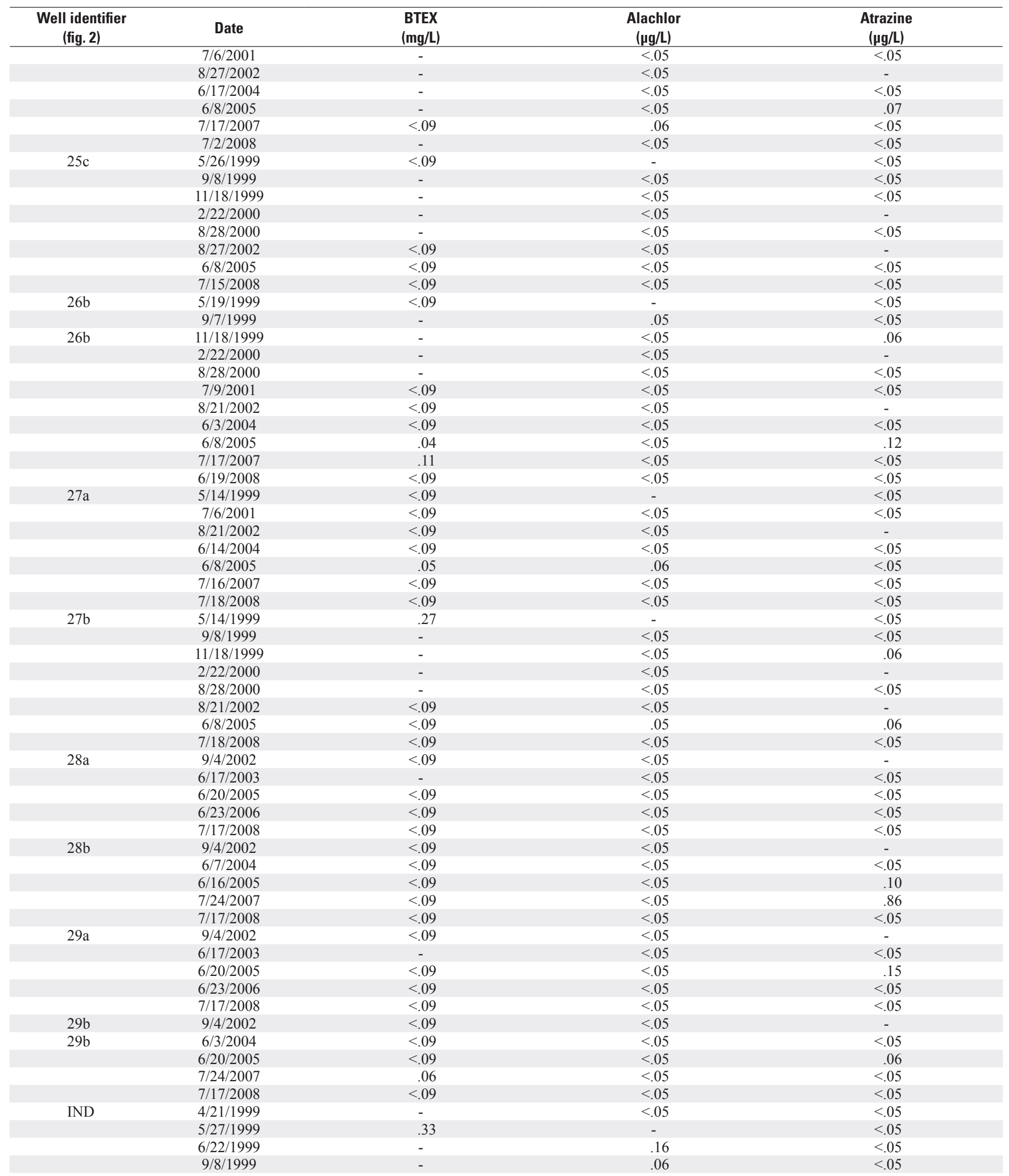


Table 21. Results of enzyme-linked immunosorbent assay (ELISA) analyses of total BTEX (benzene, toluene, ethylbenzene, and xylene), alachlor, and atrazine for water samples from all monitoring wells.-Continued

[a,b,c in identifier indicates relative depth of the well in each nest from "a" the deepest to "c" the shallowest. For well nest 4, 4a is deepest, 4c is intermediate, and $4 \mathrm{~b}$ is shallowest; $\mathrm{mg} / \mathrm{L}$, milligrams per liter; $\mu \mathrm{g} / \mathrm{L}$, micrograms per liter; <, less than; -, not analyzed; IND, combined well-field sample]

\begin{tabular}{|c|c|c|c|c|}
\hline $\begin{array}{l}\text { Well identifier } \\
\text { (fig. 2) }\end{array}$ & Date & $\begin{array}{c}\text { BTEX } \\
\text { (mg/L) }\end{array}$ & $\begin{array}{c}\text { Alachlor } \\
(\mu \mathrm{g} / \mathrm{L})\end{array}$ & $\begin{array}{c}\text { Atrazine } \\
\text { ( } \mu \mathrm{g} / \mathrm{L})\end{array}$ \\
\hline \multirow[t]{17}{*}{ IND } & $10 / 28 / 1999$ & - & $<.05$ & .06 \\
\hline & $10 / 28 / 1999$ & - & .09 & $<.05$ \\
\hline & 11/24/1999 & - & .07 & .08 \\
\hline & 12/15/1999 & - & .07 & .09 \\
\hline & $3 / 2 / 2000$ & - & $<.05$ & - \\
\hline & $4 / 3 / 2000$ & - & $<.05$ & - \\
\hline & $5 / 23 / 2000$ & $<.09$ & $<.05$ & $<.05$ \\
\hline & $7 / 13 / 2000$ & - & $<.05$ & .19 \\
\hline & $9 / 7 / 2000$ & - & $<.05$ & .09 \\
\hline & $7 / 19 / 2001$ & $<.09$ & $<.05$ & .11 \\
\hline & $9 / 3 / 2002$ & $<.09$ & $<.05$ & - \\
\hline & $6 / 19 / 2003$ & - & $<.05$ & .23 \\
\hline & $6 / 15 / 2004$ & $<.09$ & $<.05$ & $<.05$ \\
\hline & $6 / 21 / 2005$ & $<.09$ & $<.05$ & $<.05$ \\
\hline & $6 / 26 / 2006$ & .10 & $<.05$ & $<.05$ \\
\hline & $7 / 25 / 2007$ & .06 & .06 & $<.05$ \\
\hline & $7 / 18 / 2008$ & $<.09$ & $<.05$ & .08 \\
\hline
\end{tabular}




\section{References Cited}

Applin, KR and Zhao, N., 1989, The kinetics of Fe(II) oxidation and well encrustation: Ground Water, v. 27, p.168-174.

Freeze, R.A., and Cherry, J.A., 1979, Groundwater: Englewood Cliffs, N.J., Prentice-Hall, 604 p.

Childress, C.J.O., Foreman, W.T., Connor, B.F., and Maloney, T.J., 1999, New reporting procedures based on longterm method detection levels and some considerations for interpretations of water-quality data provided by the U.S. Geological Survey National Water Quality Laboratory: U.S. Geological Survey Open-File Report 99-193, 19 p.

City of Independence, Missouri, 2003, Wellhead protection plan: Independence, Missouri, $42 \mathrm{p}$.

Driscoll, F.G., 1986, Groundwater and wells: St. Paul, Minn., Johnson Filtration Systems Inc., 1,089 p.

Harbaugh, A.W., 2005, MODFLOW-2005, the U.S. Geological Survey modular ground-water model-The groundwater flow process: U.S. Geological Survey Techniques and Methods 6-A16, variously paginated.

Hauck, H.S., and Nagel, C.D., 1999, Water resources data, Missouri, water year 1998: U.S. Geological Survey WaterData Report MO-98-1, 434 p.

Hauck, H.S., and Nagel, C.D., 2000, Water resources data, Missouri, water year 1999: U.S. Geological Survey WaterData Report MO-99-1, 390 p.

Hauck, H.S., and Nagel, C.D., 2001, Water resources data, Missouri, water year 2000: U.S. Geological Survey WaterData Report MO-00-1, 430 p.

Helsel, D.R., and Hirsch, R.M., 2002, Statistical methods in water resources: Studies in environmental science 49: New York, Elsevier Science Publishing Company, 522 p.

Helsel, D.R, 2005, Nondetects and data analysis - Statistics for censored environmental data: John Wiley and Sons, New York, 250 p.

Hem, J.D., 1992, Study and interpretation of chemical characteristics of natural water ( $3^{\text {rd }}$ ed): U.S. Geological Survey Water-Supply Paper 2254, 263 p.

Kelly, B.P., and Rydlund, P.H., 2006, Water-quality changes between the Missouri River and three pumping wells of the Independence, Missouri well field caused by riverbank filtration, 2003-2005: U.S. Geological Survey Scientific Investigations Report 06-5174, 48 p.
Kelly, B.P., 2002a, Ground-water monitoring plan, water quality, and variability of agricultural chemicals in the Missouri River alluvial aquifer near the City of Independence, Missouri well field, 1998-2000: U.S. Geological Survey WaterResources Investigations Report 02-4096, 69 p.

Kelly, B.P., 2002b, Ground-water flow simulation and chemical and isotopic mixing equation analysis to determine the contribution of the Missouri River to the City of Independence, Missouri well field: U.S. Geological Survey WaterResources Investigations Report 02-4208, 53 p.

Kelly, B.P., 2000, Effects of alternative Missouri River management plans on ground-water levels in the lower Missouri River flood plain: U.S. Geological Survey Water-Resources Investigations Report 00-4052, 128 p.

Kelly, B.P., 1996a, Simulation of ground-water flow and contributing recharge areas in the Missouri River alluvial aquifer at Kansas City, Missouri and Kansas: U.S. Geological Survey Water-Resources Investigations Report 96-4250, $93 \mathrm{p}$.

Kelly, B.P., 1996b, Design of a monitoring well network for the City of Independence, Missouri well field using simulated ground-water flow paths and travel times: U.S. Geological Survey Water-Resources Investigations Report 96-4264, 27 p.

Kelly, B.P., and Blevins, D.W., 1995, Vertical hydraulic conductivity of soil and potentiometric surface of the Missouri River alluvial aquifer at Kansas City, Missouri and KansasAugust 1992 and January 1993: U.S. Geological Survey Open-File Report 95-322, 19 p.

Konikow, L.F., 1978, Calibration of ground-water models, in Specialty Conference on Verification of Mathematical and Physical Models in Hydraulic Engineering, College Park, Md., 1978, Proceedings: American Society of Civil Engineering, p. 87-93.

McDonald, M.G., and Harbaugh, A.W., 1988, A modular three-dimensional finite-difference ground-water flow model: U.S. Geological Survey Techniques of WaterResources Investigations, book 6, chap. A1, 576 p.

Missouri Department of Natural Resources, 2009a, Missouri National Pollution Discharge Elimination System (NPDES) Facilities: Missouri Spatial Data Information Service, accessed June 29, 2009 at ftp://msdis.missouri.edu/pub/ state/st_npdes_outfall.zip.

Missouri Department of Natural Resources, 2009b, Missouri National Pollution Discharge Elimination System (NPDES) Storm Water Facilities Covered Under a Master General Permit: Missouri Spatial Data Information Service, accessed June 29, 2009 at ftp://msdis.missouri.edu/pub/state/ st_npdes_storm.zip. 
Missouri Department of Natural Resources, 2009c, Superfund Sites: Missouri Spatial Data Information Service, accessed June 22, 2009 at ftp://msdis.missouri.edu/pub/state/ st_superfund.zip.

Missouri Department of Natural Resources, 2008a, Below Ground Storage Tanks: Missouri Spatial Data Information Service, accessed February 10, 2009 at ftp://msdis.missouri.edu/pub/state/st_blw_grd_tanks.zip.

Missouri Department of Natural Resources, 2008b, Hazardous Waste Generators: Missouri Spatial Data Information Service, accessed September 10, 2008 at ftp://msdis.missouri.edu/pub/state/st_haz_generator.zip.

Missouri Department of Natural Resources, 2008c, IND MIN_MINES, Industrial Mineral Mines: Missouri Spatial Data Information Service, accessed October 28, 2008 at ftp://msdis.missouri.edu/pub/state/st_ind_min_mines_utm.zip.

Missouri Department of Natural Resources, 2007a, Above Ground Storage Tanks: Missouri Spatial Data Information Service, accessed June 29, 2009 at ftp://msdis.missouri.edu/ pub/state/st_abv_grd_tanks.zip.

Missouri Department of Natural Resources, 2007b, Census of Missouri public water systems 2007: Jefferson City, Division of Environmental Quality, Public Drinking Water Program.

Missouri Department of Natural Resources, 2006, Well Logs: Missouri Spatial Data Information Service, accessed October 31, 2007 at ftp://msdis.missouri.edu/pub/state/ st_well_logs.zip.

Missouri Department of Natural Resources, 2003, Code of State Regulations, Contaminant levels and monitoring: Jefferson City, Public Drinking Water Program, 31 p.

Missouri Department of Natural Resources, 2001, Census of Missouri public water systems 2001: Jefferson City, Division of Environmental Quality, Public Drinking Water Program.

Missouri Department of Natural Resources, 1998, Census of Missouri public water systems 1998: Jefferson City, Division of Environmental Quality, Public Drinking Water Program.

Missouri Department of Natural Resources, 1997, Census of Missouri public water systems 1997: Jefferson City, Division of Environmental Quality, Public Drinking Water Program.
Missouri Department of Natural Resources, 1996, Census of Missouri public water systems 1996: Jefferson City, Division of Environmental Quality, Public Drinking Water Program.

Missouri Department of Natural Resources, 1991, Census of Missouri public water systems 1991: Jefferson City, Division of Environmental Quality, Public Drinking Water Program, $181 \mathrm{p}$.

Missouri Resource Assessment Program, 2005, 2005 Land Use Land Cover, Clay County, Missouri: Missouri Spatial Data Information Service, accessed June 23, 2009, at http:// msdis.missouri.edu/pub/lulc/lulc05/clay_lulc05.e00.gz.

Missouri Resource Assessment Program, 2005, 2005 Land Use Land Cover, Jackson County, Missouri: Missouri Spatial Data Information Service, accessed June 23, 2009, at http://msdis.missouri.edu/pub/lulc/lulc05/ jacks_lulc05.e00.gz.

National Oceanic and Atmospheric Administration, 2008, Record of climatological observations Independence, MO: National Climatic Data Center, accessed on July 17, 2008 at http://www.ncdc.noaa.gov/oa/climate/stationlocator.html.

Perry, C.A., Clement, R.W., and Studley, S.E., 1997, Delineation of flooding within the upper Mississippi River basinFlood of July 19, and 27, 1993, in Kansas City, Missouri and Kansas City, Kansas, and vicinity: U.S. Geological Survey Hydrologic Investigations Atlas 735-E , 3 sheets.

Poeter, E.P., Hill, M.C., Banta, E.R., Mehl, Steffen, and Christensen, Steen, 2005, UCODE_2005 and six other computer codes for universal sensitivity analysis, calibration, and uncertainty evaluation: U.S. Geological Survey Techniques and Methods 6-A11, 283 p.

Pollock, D.W., 1994, User's guide for MODPATH/ MODPATH-PLOT, Version 3-A particle tracking postprocessing package for MODFLOW, the U.S Geological Survey finite-difference ground-water flow model: U.S. Geological Survey Open-File Report 94-464.

Rounds, S.A., 2006, Alkalinity and acid neutralizing capacity (version 3.0): U.S. Geological Survey Techniques of WaterResources Investigations, book 9, chap. A6., section 6.6, accessed Dec 10, 2009 from http://water.usgs.gov/owq/ FieldManual/Chapter6/section6.6/.

U.S. Geological Survey, 2007, 06893000 Missouri River at Kansas City, MO: U.S. Geological Survey Water-Data Report 2007 accessed May 20, 2008, at http//wdr.water. usgs.gov/wy2007/pdfs/06893000.2007.pdf. 
Publishing support provided by:

Denver and Rolla Publishing Service Centers

For more information concerning this publication, contact: Director

USGS Missouri Water Science Center

1400 Independence Road

Rolla, M0 65401

(573) 308-3667

Or visit the Missouri Water Science Center Web site at: http://mo.water.usgs.gov/ 
